\title{
MINERALOGICAL CHARACTERISTICS WHICH AFFECT MINERAL PROCESSING OF FARO AND VANGORDA ORES, YUKON, CANADA
}

\section{by}

\section{JOHN M.D. WILSON}

\author{
A thesis submitted to \\ the Faculty of Graduate Studies and Research \\ in partial fulfilment of \\ the requirements for the degree of \\ Doctor of Philosophy \\ Department of Geology
}

Carleton University

Ottawa, Ontario

May 23, 1995

(O) copyright

1995, John M.D. Wilson 
National Library

of Canada

Acquisitions and

Bibliographic Services Branch

395 Wellington Street

Ottawa, Ontario

K1A ON4
Bibliothèque nationale du Canada

Direction des acquisitions et des services bibliographiques

395 , rue Wellington

Ottawa (Ontario)

K1A ON4
Your file Votre réference

Our file Notre référence
THE AUTHOR HAS GRANTED AN

IRREVOCABLE NON-EXCLUSIVE

LICENCE ALLOWING THE NATIONAL

LIBRARY OF CANADA TO

REPRODUCE, LOAN, DISTRIBUTE OR

SELL COPIES OF HIS/HER THESIS BY

ANY MEANS AND IN ANY FORM OR

FORMAT, MAKING THIS THESIS

AVAILABLE TO INTERESTED

PERSONS.
L'AUTEUR A ACCORDE UNE LICENCE IRREVOCABLE ET NON EXCLUSIVE PERMETTANT A LA BIBLIOTHEQUE NATIONALE DU CANADA DE REPRODUIRE, PRETER, DISTRIBUER OU VENDRE DES COPIES DE SA THESE DE QUELQUE MANIERE ET SOUS QUELQUE FORME QUE CE SOIT POUR METTRE DES EXEMPLAIRES DE CETTE THESE A LA DISPOSITION DES PERSONNE INTERESSEES.

L'AUTEUR CONSERVE LA PROPRIETE DU DROIT D'AUTEUR QUI PROTEGE SA THESE. NI LA THESE NI DES EXTRAITS SUBSTANTIELS DE CELLECI NE DOIVENT ETRE IMPRIMES OU AUTREMENT REPRODUITS SANS SON AUTORISATION.

ISBN $\quad 0-612-02966-2$

\section{Canada}


Nom

Dissertation Abstracts International est organisé en catégories de sujets. Veuillez s.v.p. choisir le sujet qui décrit le mieux votre thèse et inscrivez le code numérique approprié dans l'espace réservé ci-dessous.

\section{Catégories par sujets}

\section{HUMANITÉS ET SCIENCES SOCIALES}

\begin{tabular}{|c|}
\hline 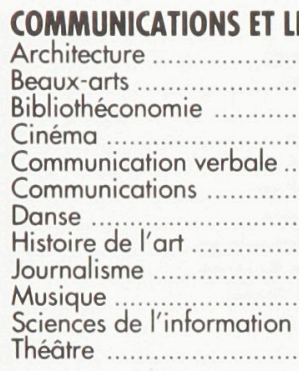 \\
\hline
\end{tabular}

\section{ÉDUCATION}

Généralités......

Administration

Art

Commerce ............................. 0688

Economie domestique ............... 0278

Éducation permanente ................0516

Education préscolaire ............... 0518

Éducation sanitaire 0680

Enseignement agricole ..................0517

Enseignement bilingue et

mulficulturel

.0282

0521

0524

0527

.0533

0533
0529

0745

0288
0277

0530

.0520

0279

Langues et littérature
Collèges communautaires ........... 027

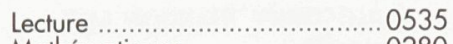

Mathématiques ................................ 0280

Musique …........................... 0522

Philosophie de l'éducation ........... 0998

Physique ............................... 0523

Programmes d'études et

enseignement .......................0727

Psychologie ............................ 0525

Sciences sociales ........................ 0534

Sociologie de l'éducation ............ 0340

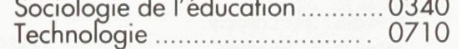

\section{LANGUE, LITTÉRATURE ET}

\section{LINGUISTIQUE}

Langues

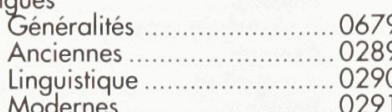

Modernes

Littérature

Généralités ........................ 0401

Anciennes ........................ 0294

Mediévale ................................. 0297

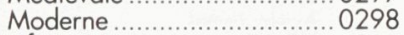

Africaine ................................. 0316

Américaine …..................... 0591

Anglaise .......................... 0593

Canadienne (Anglaise) ........ 0352

Canadienne (Française) ....... 0355

Germanique .....................0311

Latino-américaine ...................... 0312

Moyen-orientale ................... 0315
Romane

Slave et est-européenne .......0314

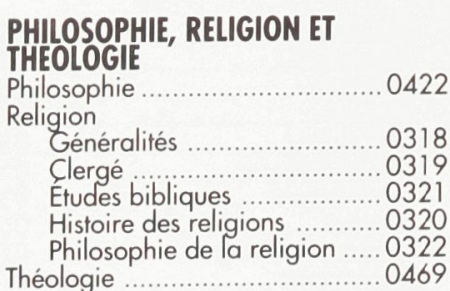

Théologie

\section{SCIENCES SOCIALES}

Anthropologie

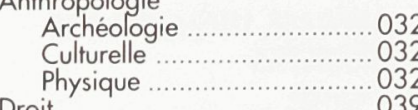

Droit

Physique

Economie

Généralités

Economie agricole ...................... 0503

Economie du travail ............ 0510

Finances ........................... 0508

Théorie

Études américaines

Études canadiennes

Etudes féministes

Folklore

Géographie

Gérontologie

Gestion des affaires

Généralités

Administration

Banques

Comptabilité

Marketing

Histoire

Histoire générale

\section{SCIENCES ET INGÉNIERIE}

\section{SCIENCES BIOLOGIQUES}

Agricultur

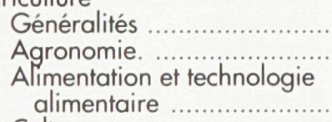

Culture

0473

0285

Elevage et alimentation ........ 0475

Exploitation des péturages ...0 0777

Pathologie animale .............. 0476
Pathologie végétale ............ 0480

Physiologie végétale ..............0817

Sylviculture et faune ............ 0478

Technologie du bois .............. 0746

Biologie

Généralités ....................... 030

Anatomie ............................... 028

Biologie (Statistiques) .......... 0308

Biologie moléculaire ............ 0309

Cellule ................................. 0379

Ecologie ............................. 0329

Entomologie ............................... 0353

Génétique ........................ 0369

Microbiologie .......................... 0317

Neurologie ...................0317

Océanographie ......................... 0416

Physiologie ............................ 0433

Radiation .......................... 082

Science vétérinaire .............. 0778
Zoologie

Généralités

Medicale

0786

SCIENCES DE LA TERRE

Biogeochimie ....................... 0425

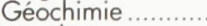

Géodésie

Géographie physique
Géologie .......................... 0372

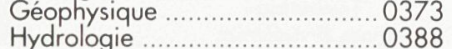

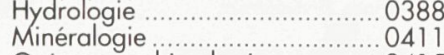

Océanographie physique ......... 0415

Paléobotanique ....................... 0345

(1)...0426

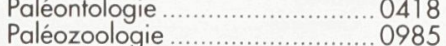

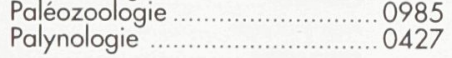

\section{SCIENCES DE LA SANTÉ ET DE} L'ENVIRONNEMENT

\section{Économie domestique}

Sciences de l'environnement ..... 0768

Sciences de la santé

Généralités ................... 0566

Alimentation et nutrition ....... 0570

Audiologie ........................ 0300

Chimiothérapie ................. 0992

Dentisterie ........................ 0567

Developpement humain _.....0758

Enseignement 0350

Immunologie ........................... 0982

Loisirs

Médecine du travail et

Médecine et chirurgie

Obstétrique et gynécologie ...0380

Ophtalmologie ................ 038

Orthophonie ........................... 0460

Pathologie ....................... 0571

Pharmacologie 0419

Physiothérapie .................. 0382

Radiologie ...................... 0574

Santé mentale ….................... 0347

Santé publique ........................ 0573

Soins infirmiers …................ 0569

\section{SCIENCES PHYSIQUES}

\section{Sciences Pures}

Chimie

Biochimie.

Chimie agricole

Chimie analytique

Chimie minerale

Chimie nucléaire

Chimie organique

Chimie pharmaceutique

Physique

Polym res

Physique

Genéralités

Acoustique

Astronomie et

astrophysique

ectronique et électricité

Fluides et plasma

Météorologie

Optique

Particules (Physique

nucléaire

Physique atomique

Physique de l'état solide.

Physique moléculaire

Physique nucléaire

Radiation

Statistiques

Sciences Appliqués Et

Technologie

Informatique

Ingénierie

Généralités

Agricole

Automobile...
0509

0511
0323

0323
0385

0453

0358

0366

0351

0310

0454

0272

0338

Ancienne

Médiévale...

Moderne

Histoire des noirs

Africaine

Canadienne

Etats-Unis

Européenne

Moyen-orientale

Latino-américaine.

Asie, Australie et Océanie

Histoire des sciences

Loisirs

Planification urbaine et

régionale

Science politique

Généralités

Administration publique

Droit et relations

internationales

Sociologie

Généralités

Aide et bien-àtre social ...... 0626

Criminologie et

établissements

pénitentiaires

Demographie

Etudes de $\mathrm{l}^{\prime}$ individu et

de la famille

Études des relations

interethniques et

des relations raciales

Structure et développement

social

Théorie et méthodes.

Travail et relations

industrielles

0578

Transports
Travail social

Biomédicale

Chaleur et ther

modynamique

Conditionnement

(Emballage)

Génie aérospatial

Génie chimique

Génie civil 
Thesis contains black and white and/or coloured graphs/tables/photographs which when microfilmed may lose their significance. The hardcopy of the thesis is available upon request from Carleton University Library. 


\begin{abstract}
A study of the Faro and Vangorda $\mathrm{Zn}-\mathrm{Pb}-\mathrm{Ag}$ ores and concentrator products was made by image analysis to evaluate the influence their mineralogical characteristics have on grade and recovery of lead, zinc, silver and gold. Drill-core and concentrator samples were characterized by mineral identification and modal analysis, and by determining ore mineral grain size distributions, precious metal content of the ore minerals, and ore mineral liberations and associations. The detailed behaviour in the concentrator of sphalerite and galena from each deposit was calculated by materials balance.
\end{abstract}

A technique for measuring ore mineral associations by the proportion of perimeter adjacent to other minerals was developed and tested. The technique allows the determination of mineral associations, preferred mineral associations, preferred mineral associations by grain size, preferred breakage and relative bond strengths between minerals. Sphalerite and galena are preferentially associated with pyrite in pyritic ores, with quartz in quartzose ores, and with barite in baritic ores. In quartzose ores a significant proportion of sphalerite and galena is disseminated as fine grains in the quartz matrix. In pyritic and baritic ores coarse-grained sphalerite and galena have a higher association with each other than their fine-grained counterparts. In those same ores finegrained galena is more closely associated with pyrite than coarse-grained galena. In baritic Vangorda ore, an association of fine-grained sphalerite and galena with siderite is detected. These textures have implications for mineral beneficiation. There is strong evidence that preferred breakage takes place during grinding. Coarse-grained pyrite and barite break preferentially from sphalerite and galena, whereas sphalerite and galena have 
a slight tendency not to detach from each other. Medium-grained siderite detaches poorly from sphalerite and galena. It is interpreted that preferential breakage is due to differences in bond strength between sphalerite, galena and the other major minerals. A sequence for increasing bond strength between sphalerite and the other minerals is: Barite $<$ Pyrite $<$ Galena $<$ Siderite. Similarly for galena the sequence is: Barite $<$ Pyrite $<$ Sphalerite $<$ Siderite. The sequences are confirmed for both the Faro and Vangorda ores.

The major factors which reduce concentrate grades and metal recoveries are the presence of trace amounts of secondary minerals (covellite, digenite, chalcocite, bornite, goethite, secondary galena), as well as marcasite and pyrrhotite, the presence of a large amount of fine-grained galena, the associations of sphalerite and galena with siderite and each other and the mineralogical distribution of much of the silver in acanthite and the gold in gold-silver-alloy. 


\section{ACKNOWLEDGEMENTS}

The author extends special thanks to Dr. Paul Mainwaring for suggesting the topic and providing initial guidance, and to Drs. William Petruk and George Chao for supervising the thesis work. Thanks are also extended to Bill Scheding, Gordon Wilson, Ian Orford, Godfrey Macdonald, Dr. Gregg Jilson, Dr. Lee Pigage, Peter Ledwidge, and Dumitru Tulliu, all formerly of Curragh Resources, for access to and assistance with samples and for providing information. Thanks also to Dealton Owens for assistance with microprobe analyses, to Michel Beaulne, Jim Greer, Miki Raicevic and Pierre Groulx for sample preparation, to Dr. Rolando Lastra for assistance with microprospecting, to Dr. Jan Szymanski and Paul Carriere for assistance with X-ray diffraction and Errol van Huyssteen for helpful suggestions. Finally, I thank my wife Ruth for patience and support through countless weekends alone while raising a young family. 
PAGE

Acceptance Sheet

Abstract

Acknowledgements

ii

Table of Contents

List of Tables

List of Figures

List of Plates

iii

v

vi

xi

xv

xix

CHAPTER I: Introduction 1

1.1 Location 1

1.2 History 3

1.3 Previous Geologic Work 4

1.4 Objectives and Scope 5

CHAPTER II: Geologic Setting

2.1 Regional Setting 7

2.2 Selwyn Basin 9

2.3 Anvil District $\quad 12$

2.3.1 Stratigraphy 13

2.3.2 Intrusives 15

2.3.3 Structure and Metamorphism 15

2.4 The Ore Deposits

2.4.1 Genetic Model 16

$\begin{array}{ll}\text { 2.4.2 Sulphide Lithology } & 17\end{array}$

2.4.3 Faro Deposit $\quad 18$

2.4.4 Vangorda Deposit 21

CHAPTER III: Methodology

3.1 Sampling and Sample Preparation

3.1.1 Faro Ore 24

3.1.2 Vangorda Ore 24

3.1.3 Faro and Vangorda Concentrator Products 25

3.2 Chemical Analysis

3.2.1 Ores 
3.2.2 Concentrator Products

3.3 Ore Microscopy and X-ray Analysis 27

3.4 Image Analysis $\quad 27$

3.5 Mineral Associations by Perimeter 31

3.6 Microprobe Analysis $\quad 35$

3.7 Dynamic-SIMS Analysis 35

3.8 Materials Balance $\quad 36$

3.9 Leach Testwork 38

CHAPTER IV: Mineralogy of the Faro Ore Types

4.1 Introduction 39

4.2 $2 \mathrm{~A}$ Ore 41

4.3 $2 \mathrm{BCD}$ Ore 50

$4.42 \mathrm{E}$ Ore $\quad 59$

$4.52 \mathrm{G}$ Ore 63

4.6 2H Ore 69

4.7 Mineral Grain Size Distributions of Faro Ores 73

4.8 Mineral Associations of Faro Ores 78

4.9 Summary $\quad 79$

CHAPTER V: Metallurgical Characteristics of Faro Ore

5.1 Introduction $\quad 80$

5.2 Results and Discussion
5.2.1 Grain Size Distributions of Ore Minerals in Unbroken Concentrator Feed $\quad 80$

5.2.2 Metal and Mineral Quantities and Recoveries $\quad 85$

5.2.3 Liberation $\quad 86$

5.2.4 Liberation of Sphalerite and Galena $\quad 89$

5.2.5 Liberation and Distributions of Sphalerite and Galena in the Lead Flotation Circuit

5.2.5.1 Rougher-Scavenger Flotation 90

5.2.5.2 Hydrocyclone-Regrind Ball Mill 95

5.2.5.3 Lead Cleaners 98

5.2.6 Liberation and Distributions of Sphalerite and Galena in the Zinc Flotation Circuit

5.2.6.1 Rougher-Scavenger Flotation 98

5.2.6.2 Hydrocyclone-Regrind Ball Mill 100

5.2.6.3 Zinc Cleaners 103

5.2.6.4 Final Tailings 103

5.2.7 Mineral Associations of Sphalerite and Galena 
5.2.7.1 Unbroken Concentrator Feed 105

5.2.7.2 Preferred Breakage 105

5.2.7.3 Concentrator Samples 108

5.2.7.4 Distribution of Binary Particles 116

5.2.7.5 Encapsulated Ore Minerals 116

5.2.7.6 Mineral Associations of Gangue Minerals in the Final Lead and Zinc Concentrates

5.2.7.7 Associations of Sphalerite and Galena in the Lead Flotation Circuit 118

5.2.7.8 Associations of Sphalerite and Galena in the Zinc Flotation Circuit

5.2.8 Relationship between Base Metal Recovery and Grade and Mineralogy in Faro Ore

5.2.8.1 Lead Recovery and Grade

5.2.8.2 Zinc Recovery and Grade 124

5.2.9 Liberation of Tetrahedrite and Gold-Silver 126

5.2.10 Mineral Associations of Tetrahedrite 126

5.2.11 Silver Distribution in Concentrator Feed 127

5.2.12 Mineralogical Distribution of Silver in Faro

Concentrator

128

5.2.13 Deleterious Minerals

CHAPTER VI: Mineralogy of the Vangorda Ore Types

6.1 Introduction 133

6.2 4A Ore 134

6.3 4E Ore 138

6.4 4G Ore 144

6.5 General Mineralogy and Grain Size Distributions
of Vangorda Ores

6.6 Mineral Associations of Vangorda Ores 155

$\begin{array}{ll}\text { 6.7 Summary } & 159\end{array}$

CHAPTER VII: Metallurgical Characteristics of Vangorda Ore

7.1 Introduction

160

7.2 Results and Discussion

7.2.1 Grain Size Distributions of Ore Minerals in Unbroken Concentrator Feed 160

7.2.2 Metal and Mineral Quantities and Recoveries 164

7.2.3 Liberation and Distributions of Sphalerite and Galena in the Lead Flotation Circuit 
7.2.3.1 Rougher-Scavenger Flotation $\mathrm{G}$ and $\mathrm{H}$ Banks

7.2.3.2 Rougher-Scavenger Flotation I Bank

7.2.3.3 Rougher Hydrocyclone-Regrind Ball Mill

7.2.3.4 Scavenger Hydrocyclone-Regrind Ball Mill

7.2.3.5 Lead Cleaners

7.2.4 Liberation and Distributions of Sphalerite and Galena in the Zinc Flotation Circuit

7.2.4.1 Rougher-Scavenger Flotation $\mathrm{K}$ and $\mathrm{L}$ Banks

7.2.4.2 Hydrocyclone-Regrind Ball Mill

7.2.4.3 Rougher-Scavenger Flotation J Bank

7.2.4.4 Rougher-Scavenger Columns Circuit

178

7.2.4.5 Final Tailings

7.2.5 Mineral Associations of Sphalerite and Galena

7.2.5.1 Unbroken Concentrator Feed

7.2.5.2 Preferred Breakage

7.2.5.3 Concentrator Samples

7.2.5.4 Distribution of Binary Particles 189

7.2.5.5 Encapsulated Ore Minerals

7.2.5.6 Mineral Associations of Gangue Minerals in the

Final Lead and Zinc Concentrates

7.2.5.6.1 Associations of Sphalerite and Galena in the Lead Flotation Circuit

7.2.5.6.2 Associations of Sphalerite and Galena in the Zinc Flotation Circuit

7.2.6 Relationship between Base Metal Recovery and

Grade and Mineralogy in Vangorda Ore

7.2.6.1 Lead Recovery and Grade

7.2.6.2 Zinc Recovery and Grade

7.2.7 Liberation of Silver-Carrier Minerals and Gold-Silver 197

7.2.8 Associations of Silver and Gold-Carrier Minerals 198

7.2.9 Silver and Gold Distribution and Recovery 198

7.2.9.1 Silver Distribution and Recovery 200

7.2.9.2 Gold Distribution and Recovery 203

7.2.10 Deleterious Minerals 
APPENDIX 6: Composition of Carbonates in Faro Ore 220

APPENDIX 7: Faro and Vangorda Grinding Circuits Operating Parameters 221

APPENDIX 8: Faro Concentrator Solid Flowrates 222

APPENDIX 9: Faro Stream Particle Size Distributions 223

APPENDIX 10: Faro Concentrator Measured and Balanced Stream Assays

and Distribution (\%)

APPENDIX 11: Balanced Mineral Quantities in Faro Concentrator (wt\%) 226

APPENDIX 12: Mineral Associations of Sphalerite and Galena in Faro

Concentrator Products by Sieve Fractions (\%per) 228

APPENDIX 13: Location of Vangorda Samples 230

APPENDIX 14: Composition of Sphalerite in Vangorda Ore 232

APPENDIX 15: Trace Element Content of Galena in Vangorda ore 233

APPENDIX 16: Composition of Tetrahedrite-Tennantite in Vangorda Ore 234

APPENDIX 17: Composition of Vangorda Carbonates 235

APPENDIX 18: Vangorda Concentrator Solid Flowrates 237

APPENDIX 19: Vangorda Concentrator Measured and Balanced Stream

Assays and Distribution 238

APPENDIX 20: Balanced Mineral Quantities in Vangorda Concentrator 240

APPENDIX 21: Mineral Associations of Sphalerite and Galena in Vangorda

Concentrator Products

REFERENCES: 


\section{LIST OF TABLES}

\section{TABLE DESCRIPTION}

Minerals Identified in Faro and Vangorda Ores

Mineral Associations of Galena and Sphalerite in 2A Ore by Grain Size

Mineral Associations of Galena and Sphalerite in 2BCD Ore by Grain Size

10 Mineral Associations of Galena and Sphalerite in 2E Ore by Grain Size

11 Grain Size Distributions for Faro 2G Ore

12 Mineral Associations of Galena and Sphalerite in 2G Ore by Grain Size

13 Grain Size Distributions for Faro 2H Ore

14 Mineral Associations of Galena and Sphalerite in 2H Ore by Grain Size 
19 Liberation Analysis of the Zinc Circuit of the Faro

Concentrator (TPH)

21. Normalized Mineral Associations in Rod Mill Discharge and Lead Circuit Feed

Balanced Distribution of Sphalerite among Binary and

Ternary Particles in Faro Concentrator

Balanced Distribution of Galena among Binary and

Ternary Particles in Faro Concentrator

Normalized Mineral Associations in Faro

Concentrator Products

Flowrates and Distributions of Galena and Sphalerite Locked in Binary Particles

Distribution of Sphalerite and Galena in Free, Exposed and Encapsulated Grains in Faro Final Tailings

Mineralogical Distribution of Silver in Selected Streams of Faro Concentrator

Mineralogical Factors which Reduce Metal Recovery and Grade in Faro Concentrator 
Mineral Associations of Galena and Sphalerite in 4E Ore by Grain Size

Mineral Associations of Galena and Sphalerite in 4G Ore by Grain Size

Size Distribution of Tetrahedrite-Tennantite Grains in Vangorda Ore

Particle Size Distributions of Selected Streams in Vangorda Concentrator

Liberation of Galena and Sphalerite in the Vangorda Concentrator (TPH)

Normalized Mineral Associations of Galena and Sphalerite in Lead Circuit Feed

Balanced Distribution of Sphalerite among Binary and Ternary Particles in each Stream of Vangorda Circuit

Balanced Distribution of Galena among Binary and

Ternary Particles in each Stream of Vangorda Circuit

Normalized Mineral Associations in Vangorda Concentrator Products

Flowrates and Distributions of Galena and Sphalerite Locked in Binary Particles 


\section{LIST OF FIGURES}

FIGURE DESCRIPTION

PAGE

1

Location major stratiform, clastic hosted $\mathrm{Zn}-\mathrm{Pb}$

districts within Selwyn Basin

2

Distribution of the five morphogeological belts of the northern Canadian Cordillera

Simplified stratigraphic section across the Selwyn Basin as defined by Carne and Cathro (1982) showing the three major episodes of stratiform $\mathrm{Zn}-\mathrm{Pb}$ sulphide deposition

Geologic map of the Anvil $\mathrm{Zn}-\mathrm{Pb}-\mathrm{Ag}$ district showing surface projections of sulphide mineral deposits

Vertical longitudinal section of the Faro deposit looking northeast, no vertical exaggeration.

Vertical cross section 118 of the Faro deposit looking northwest, no vertical exaggeration

Vertical longitudinal section of the Vangorda deposit looking northeast, no vertical exaggeration

Vertical cross sections of the Vangorda deposit looking northeast, no vertical exaggeration

Grain size distributions of ore minerals in Faro $2 \mathrm{~A}$ ore

Galena and sphalerite associations with quartz in $2 \mathrm{~A}$ ore

11 Grain size distributions of ore minerals in Faro 2BCD ore

12 Grain size distributions of ore minerals in Faro 2E ore 
16 Faro and Vangorda grinding circuit

$17 \quad$ Faro Lead Flotation Circuit

19 Grain size distributions of ore minerals in Faro concentrator feed

Galena recovery by liberation class in Faro lead circuit

Sphalerite distribution by liberation class in Faro lead circuit

Galena distribution by liberation class and size to Faro lead regrind cyclone underflow

Sphalerite distribution by liberation class to Faro lead regrind cyclone underflow

Galena distribution by liberation class and size to Faro zinc regrind cyclone underflow

Sphalerite distribution by liberation class and size to Faro zinc regrind cyclone underflow 
Associations of galena and sphalerite with carbonates by size in $4 \mathrm{G}$ ore

Vangorda zinc flotation circuit

41 Grain size distributions of ore minerals in Vangorda concentrator feed

Galena recovery by liberation class in Vangorda lead circuit

Sphalerite distribution by liberation class in Vangorda lead circuit

Percent "liberated" in flotation streams of Vangorda lead circuit

Percent "liberated" in selected streams of Vangorda lead circuit

169

Galena and sphalerite distribution by liberation class to

Vangorda lead rougher regrind cyclone underflow

Galena and sphalerite distribution by liberation class to

Vangorda lead scavenger regrind cyclone underflow

Galena recovery by liberation class in Vangorda lead cleaner circuit

Sphalerite distribution by liberation class in Vangorda lead cleaner circuit

Sphalerite recovery by liberation class in Vangorda zinc circuit 
54 Galena and sphalerite distribution by liberation class to Vangorda zinc regrind cyclone underflow

55 Sphalerite recovery by liberation class in Vangorda zinc column circuit

56 Galena distribution by liberation class in Vangorda zinc column circuit

57 Comparison of percent free by wt\% versus perimeter\% of sphalerite and galena in selected streams of Vangorda concentrator 


\section{LIST OF PLATES}

PLATE DESCRIPTION

PAGE

1

Photograph showing ribbon-banded 2A ore

2

Photomicrograph of $2 \mathrm{~A}$ ore showing a light band as it appears in crossed-polarized light

Photomicrograph of $2 \mathrm{BCD}$ ore showing disseminated pyrite grains in a quartz matrix

Photomicrograph of 2BCD ore showing wispy masses of marcasite associated with pyrite in a matrix of sphalerite

Photomicrograph of 2BCD ore showing banded cryptocrystalline masses of marcasite and pyrite and associated coarse pyrite

Photomicrograph of $2 \mathrm{E}$ ore showing the typical arrangement of the ore minerals

Photomicrograph of a variant of $2 \mathrm{E}$ ore, called buckshot ore (2F), showing rounded megacrysts of pyrite

9 Photomicrograph of $2 \mathrm{G}$ ore showing the typical arrangement of the ore minerals

10 Photomicrograph of $2 \mathrm{H}$ ore showing the typical arrangement of the ore minerals

11 Photomicrograph of $4 \mathrm{E}$ ore showing interstitial sphalerite, galena, chalcopyrite, and quartz in a matrix of closely-spaced pyrite grains

12 Photograph showing banded 4G ore

13 Photomicrograph of $4 G$ ore showing the typical relationship between the large barite grains and the interstitial sphalerite and galena

14 Photomicrograph shows normal galena on the right and oxidized galena on the left 
15 Photomicrograph of secondary galena forming veins and rims on a particle of sphalerite in zinc concentrate

16 Photomicrograph of a covellite-bearing particle in Vangorda zinc concentrate

17 Photomicrograph of Vangorda zinc concentrate showing a particle of weathered sphalerite containing covellite, secondary galena and tennantite

18

Photomicrograph of $4 \mathrm{G}$ ore showing chalcopyrite and sphalerite with thin rims of covellite 


\section{CHAPTER 1}

\section{INTRODUCTION}

The tectonic subprovince of the Canadian Cordillera, known as the Selwyn Basin, contains one of the world's largest concentrations of sediment-hosted, stratiform leadzinc(-silver) deposits (Fig 1). Analysis of identified reserves indicates 900 million tonnes of mineralization grading approximately $9 \%$ total lead and zinc (Carne and Cathro 1982). These immense reserves will likely become one of Canada's main sources of these metals in the future. To date, only two of these deposits have been exploited: the Faro and Vangorda.

\section{LOCATION}

The Faro and Vangorda lead-zinc-silver deposits are found in the Anvil district at the western side of the Selwyn Basin. This district which is located $200 \mathrm{~km}$ northeast of Whitehorse, Yukon contains five lead-zinc ore deposits, namely the Faro, Grum, Vangorda, Dy, and Swim, which occur in a northwesterly trend just north of the town of Faro.

The five deposits taken together account for pre-mining reserves of 130 million tonnes grading $8.9 \%$ combined lead-zinc with $51 \mathrm{~g} / \mathrm{T}$ silver. There are also seven other sulphide occurrences in the area which if included in the total increase the reserves for the Anvil District to 225 million tonnes of sulphide-bearing rock (Jennings and Jilson 1986). The largest of the deposits is the Faro, presently mined out, which had pre-mining 


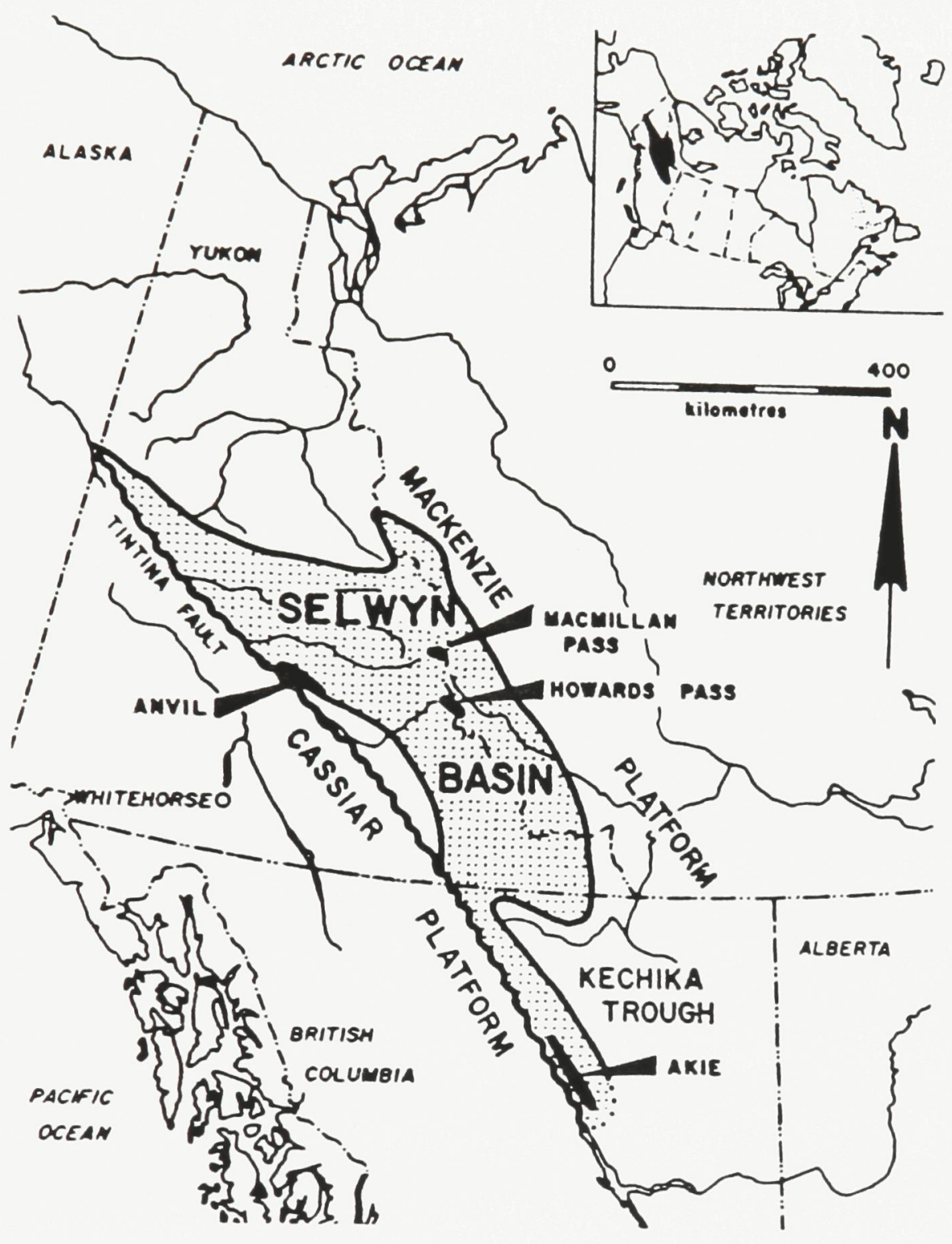

Figure 1. Location of major stratiform, clastic hosted $\mathrm{Zn}-\mathrm{Pb}$ districts within Selwyn Basin (after Pigage 1986). 
reserves of about 64 million tonnes grading $7.3 \%$ combined lead-zinc and $36 \mathrm{~g} / \mathrm{T}$ silver (Campbell and Ethier 1974). In late 1990 Curragh Resources began mining the Vangorda deposit which has reserves of 8 to 10 million tonnes grading $7.7 \%$ combined lead-zinc and $48 \mathrm{~g} / \mathrm{T}$ silver with $1 \mathrm{~g} / \mathrm{T}$ gold.

\section{HISTORY}

The Anvil District has been prospected intermittently since 1843 when the Pelly River was discovered by Robert Campbell of the Hudson's Bay Company. The Vangorda deposit was the first orebody discovered in the district when in 1953 prospector Alan Kulan found a gossan outcrop of the Vangorda deposit along the bank of Vangorda Creek (Sirola 1975). Prospector Airways optioned the property and diamond drilling between 1953 and 1955 outlined a massive sulphide deposit of 22 million tonnes (Brock 1973).

In 1964 Kerr-Addison Mines Limited located another sulphide mass of 10 million tonnes at Swim Lake, $16 \mathrm{~km}$ southeast of the Vangorda deposit (Gondi 1972).

In 1965, a joint venture of Dynasty Exploration and Cyprus Mines Corporation discovered the Faro deposit by geochemical and geophysical methods. This important discovery demonstrated the great metal potential of the Selwyn Basin. In December 1965, Anvil Mining Corporation Ltd. was formed to develop the orebodies. Stripping began in the fall of 1967 and the concentrator with an initial capacity of 6,600 tonnes per day was completed in 1969. That same year the town of Faro was built as well as a road from Carmacks in the west to Ross River further to the east of Faro.

In 1973 the Grum deposit was discovered by Kerr-Addison and AEX Minerals 
(Sirola 1975). In 1974 Dynasty Exploration merged with Anvil Mining Corporation to form Cyprus Anvil Mining Corp. In 1976 Cyprus Anvil discovered the DY deposit and by $1978 \mathrm{had}$ acquired all Kerr-Addison properties in the district. Shortly thereafter the capacity of the Faro mill was expanded to 10,000 tonnes per day. By 1982 the operation was shutdown due to suppressed metal prices.

The property was acquired in 1986 by Curragh Resources and production resumed at full capacity. Curragh Resources began stripping the Vangorda and Grum deposits in 1990 and Vangorda ore was first fed to the concentrator in December of that year. Stripping was also begun at Grum in 1990. The Faro deposit was exhausted by 1992 .

\section{PREVIOUS GEOLOGIC WORK}

The first geological work in the area was performed by G.M. Dawson who briefly described the geology of the Anvil district during his descent of the Pelly River in 1887 (Tempelman-Kluit 1972). The first map of the region was compiled by J.R. Johnston in 1935. However, the first systematic mapping of the area was begun by J.A. Roddick in 1958 and was completed by 1960 . Tempelman-Kluit $(1968,1972)$ completed a stratigraphic and structural study of the area including the Faro, Vangorda and Swim deposits. The geology of the Anvil (Faro) Mine was also described by Gondi (1972).

Several isotope studies on ores of the Anvil District have been made. Campbell and Ethier (1974) studied the sulphur isotopes and iron content of sphalerite in the Faro deposit. Lecouter (1973), Kuo and Folinsbee (1974), Kuo (1976) and Godwin and Sinclair (1982) have all studied the lead isotopes of Anvil Range deposits. Modene (1982) 
described the Grum deposit, particularly the sulphur isotopes of the ores. Shanks et al (1987) studied the sulphur and lead isotopes of the DY, Grum, Faro, SB and Swim deposits.

Carson (1977) studied the metallurgical characteristics of Grum ore. The most comprehensive publication on the geology of Anvil District is by Jennings and Jilson (1986) which represents the collective efforts of those authors as well as other coworkers, from 1971-1983.

\section{OBJECTIVES AND SCOPE}

The overall objectives of this work are to determine the mineralogical characteristics which affect the recovery of lead, zinc, silver and gold from Faro and Vangorda ores and to develop a new technique for evaluating mineral characteristics. The samples for the study were taken from both drill core and concentrator. There are two aspects to this study.

A. The effect of mineralogy on the concentrate grade and recovery of metal from the ores of the Anvil District was studied by:

1. a mineralogical characterization of the major ore types in each deposit. The mineralogical characteristics examined are: mineral identification, modal analysis, ore mineral grain size distributions, and ore mineral associations and by,

2. an evaluation of the mineralogical characteristics and behaviour of the ore minerals in the concentrator. This required the measurement of precious metal content of the ore minerals, measurement of mineral liberations and associations in each stream and 
materials balance of the quantitative data for the concentrator streams. An analysis of the mineral behaviour in the concentrator allows the identification of those mineralogical characteristics which influence metal grade and recovery.

B. The second aspect is the development of techniques for measuring mineral associations to indicate textures and relative bond strength between minerals. 


\section{CHAPTER 2 \\ GEOLOGIC SETTING}

\section{REGIONAL SETTING}

The Canadian Cordillera is subdivided into five morphogeological belts (Gabrielse and Yorath 1992). These are, from west to east, the Insular Belt, the Coast Belt, the Intermontane Belt, the Omineca Belt, which includes most of the Selwyn Basin at its northern end, and the Foreland Belt (Fig 2).

From Middle Proterozoic to Jurassic there is evidence for four distinct periods of passive deposition on the continental margin each period associated with rifting and subsidence. Geophysical evidence shows that the Precambrian crystalline basement extends westward from the Canadian Shield to the western edge of the Omineca Belt (Gabrielse and Yorath 1992). The western edge of this basement coincides with an ancient continental margin established by the first rifting event in the Middle Proterozoic. Middle Proterozoic sediments, represented by the Wernecke-Pinguicula-Mackenzie sequence, accumulated after the first event. The overlying Windermere Supergroup, subsequent to the second event, was deposited from 800 to $600 \mathrm{Ma}$ (Gabrielse 1967). The third rifting event, at $600 \mathrm{Ma}$, marks the birth of the Selwyn Basin. It developed from Late Proterozoic to Lower Devonian as a trough of argillaceous and calcareous clastic sediments between coeval carbonate platforms. In the northern Canadian Cordillera, deposition changed when passive sedimentation ended dramatically in the Middle 


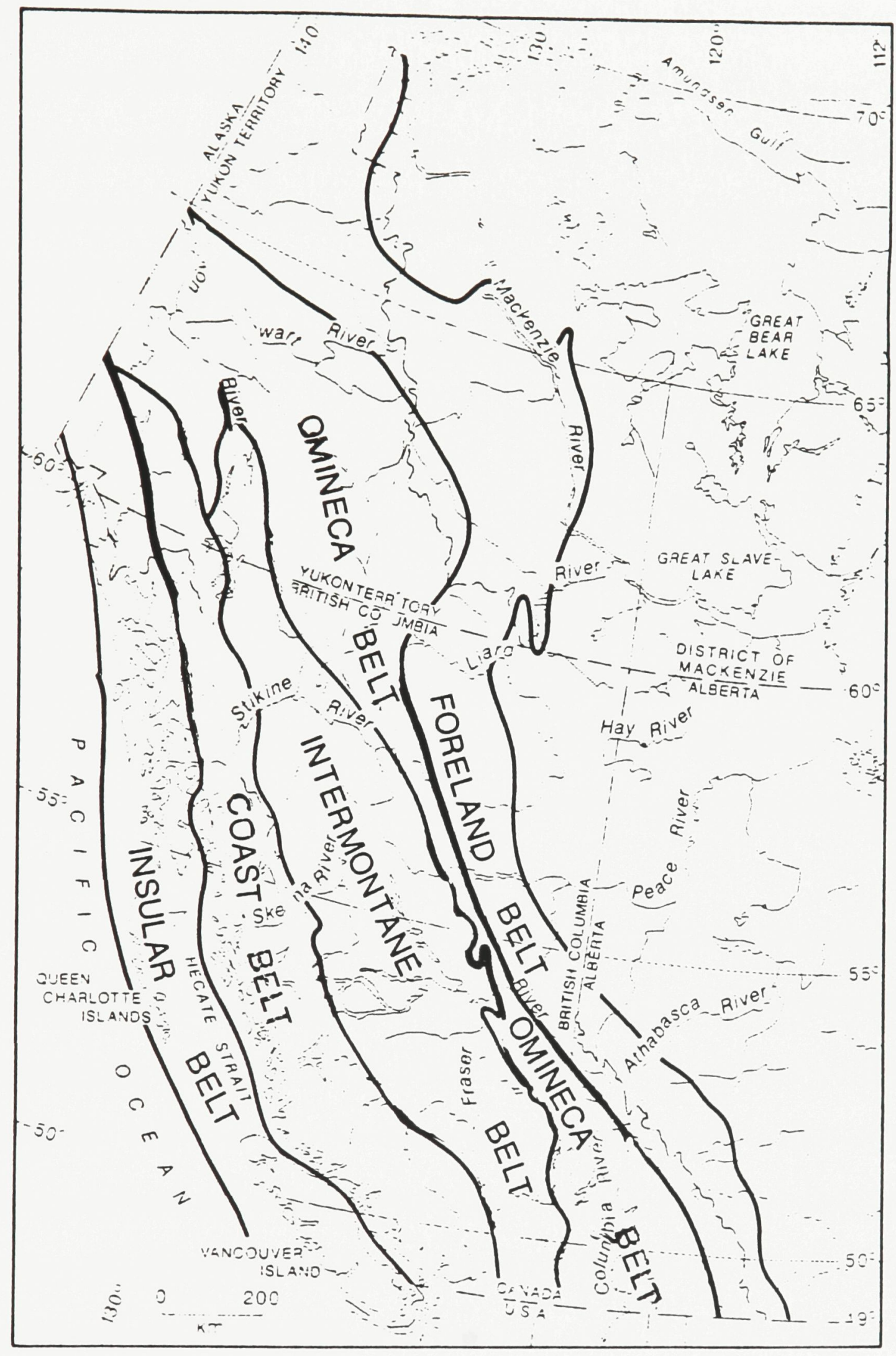

Figure 2. Distribution of the five morphogeological belts of the northern Canadian Cordillera (after Gabrielse and Yorath 1992). 
Devonian. This fourth event has been attributed to extensional rifting (Tempelman-Kluit 1979), strike-slip faulting (Eisbacher 1983) and collisional orogeny (Monger et al 1972). The result was a major marine transgression depositing a thick formation of westerlyderived coarse turbidites, including some volcanics over both the deep water clastics and the adjacent platform carbonates (Abbott et al 1983). Mississippian to Triassic shale, sandstone, chert and lesser limestone indicate a return to normal, marine, shelf sedimentation.

\section{SELWYN BASIN}

The Selwyn Basin, first named and defined by Gabrielse (1967), is a major northwesterly elongate, northeasterly convex, fault-bounded, epicratonic marine basin. It extends for a length of $1200 \mathrm{~km}$ from the Peace River Arch in northeast British Columbia to the Alaska border. There is still controversy over what is Selwyn Basin depending on the terms of reference used (Abbott et al 1986).

The Selwyn Basin is thought to have formed due to subsidence accompanying the third rifting event at approximately $600 \mathrm{Ma}$ and the subsequent development of an aulacogen (Lydon et al 1985; Cecile 1982). Thus it is viewed as having a different tectonic history than other parts of the continental margin. Sulphur isotope evidence suggests that the basin was partially isolated from open ocean water for extended periods in its history (Goodfellow and Jonasson 1984). Three major periods of mafic volcanism are recognized in the Selwyn basin: Early Cambrian, Early to Middle Ordovician, and Middle to Late Devonian (Goodfellow 1987). 
The basin consists of deep water clastic rocks bounded on the north and east by the shallow water shelf carbonate rocks of the Mackenzie Platform, on the south by similar rocks of the MacDonald Platform and on the west by the Tintina Fault and shallow water carbonates of the Cassiar Platform (Fig 3). The basin and surrounding platforms are considered parts of the Cordilleran miogeocline, the basin itself being the outboard portion (Jennings and Jilson 1986).

The oldest unit exposed in the basin is the late Proterozoic to early Cambrian "Grit Unit" (Gabrielse et al 1973). This turbidite unit is thought to be part of the Windermere Supergroup (Eisbacher 1981) and consists of sandstone and pebble conglomerate with interbedded shales.

Overlying the Grit unit is a thick sequence of early and middle Cambrian shales followed by argillaceous limestones of the upper Cambrian to lower Ordovician Rabbittkettle Formation. This unit and the Grit unit below it are not considered by some authors to be part of the basinal facies (Tempelman-Kluit 1979, Carne and Cathro 1982, Goodfellow 1987).

The Road River Formation, representing Middle Ordovician to Late Silurian, is characterized by carbonaceous, pelitic sedimentary rocks with minor coarse clastic components (Carne and Cathro 1982). They were deposited in a quiet deep water environment and may be roughly subdivided into a central chert facies surrounded by a shale facies. Road River is generally thought to mark the top of the stratigraphy of Selwyn Basin in a tectonic sense as subsequent sedimentation does not represent epicratonic or basinal accumulation (Abbott et al 1983). 


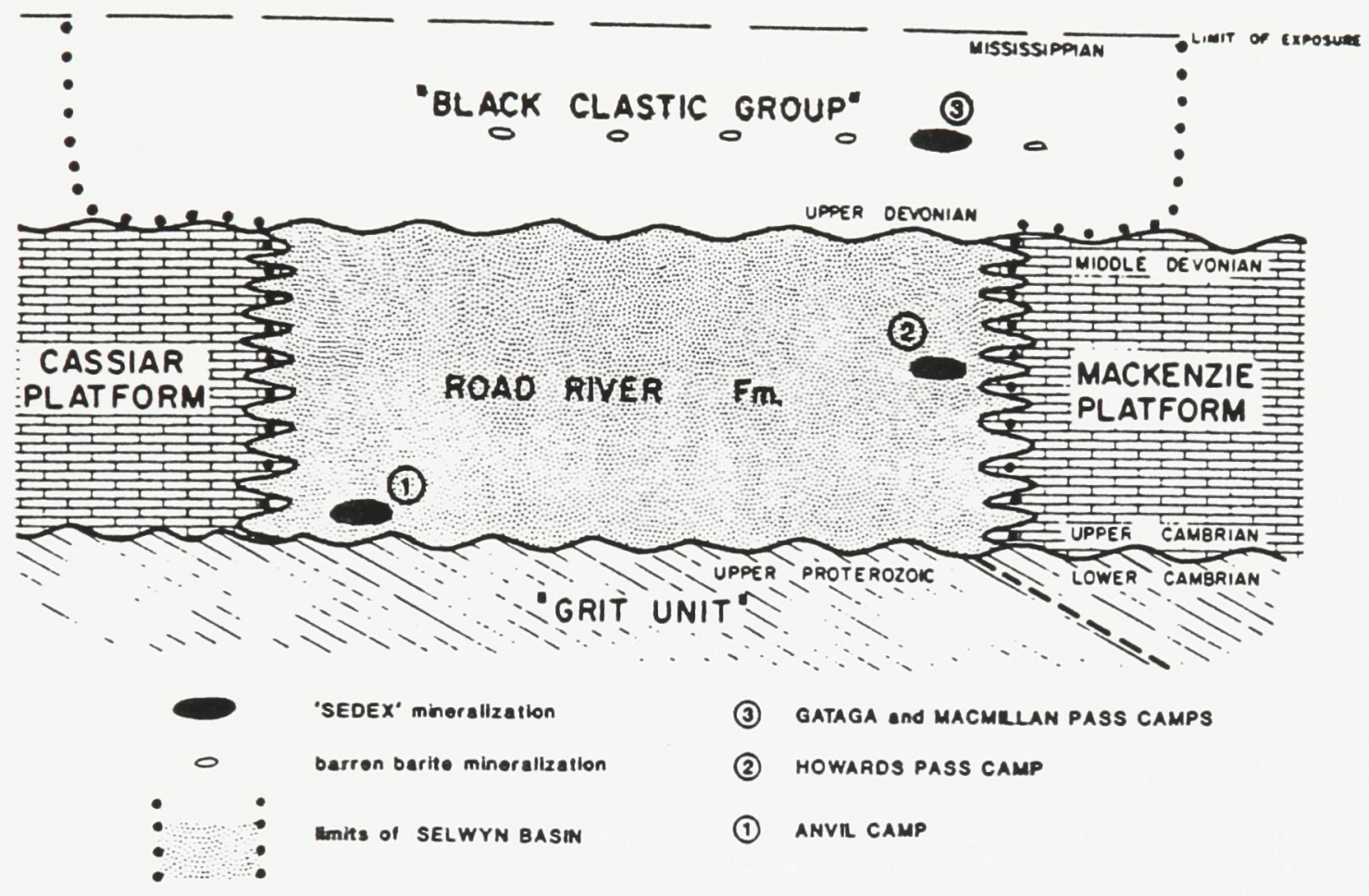

Figure 3. Simplified stratigraphic section across the Selwyn Basin as defined by Carne and Cathro (1982) showing the three major episodes of stratiform $\mathrm{Zn}-\mathrm{Pb}$ sulphide deposition. 
Passive sedimentation ended dramatically in the Middle Devonian. This resulted in erosion of the Road River and deposition of a coarse clastic rocks interbedded with black shale and chert over the Road River and adjacent platformal carbonates. This sequence is called the Earn Group, or Black Clastic Group.

Passive marine sedimentation proceeded thereafter practically uninterrupted until the Middle Jurrasic when it ended by collision of a Mesozoic island-arc with the outer miogeocline (Tempelman-Kluit 1979). This collision initiated the metamorphism and deformation of the basinal sediments. Widespread mid-Cretaceous granite, possibly as a result of subduction under the continent intruded the deformed strata. The collisional suture developed into dextral transcurrent movement along several faults in latest Cretaceous or early Tertiary time resulting in large displacements of at least $750 \mathrm{~km}$.

Stratiform lead-zinc deposits formed in the Selwyn Basin during three major periods (Goodfellow 1987). The first is represented by the Early Cambrian deposits of the Anvil District. Subsequently, in the Early Silurian, the Howard's Pass deposits were formed followed by the deposits of the MacMillan Pass and Gataga Districts in Middle to Late Devonian time (Fig 3).

\section{ANVIL DISTRICT}

The Anvil District is located in the extreme south-west of the Selwyn Basin where it is bounded on the southwest by the Tintina Fault. It is just inboard of the allochthonous rocks of the Yukon Tanana Terrane which are faulted against those of the Anvil District. 
Stratigraphy

The stratigraphy of the Anvil District ranges from Precambrian to Permian. The oldest mapped unit in the district (Fig 4) is the Mt. Mye which is a monotonous noncalcareous metapelite at least two km thick (Jennings and Jilson 1986). In areas of greenschist metamorphism it is a medium to dark grey muscovite, chlorite, quartz, plagioclase non-calcareous phyllite. In areas of amphibolite facies it is a medium greybrown biotite, muscovite, quartz, plagioclase, \pm garnet, \pm staurolite, \pm andalusite schist. The formation is thought to have been deposited in a relatively deep water environment near or on a continental rise (Jennings and Jilson 1986).

Sharply and conformably overlying the Mt. Mye is the one km thick Vangorda Formation, a silty calcareous phyllite with intercalated metabasites. The phyllite consists of thick quartz and calcite bands interlayered with thin intricately folded grey muscovite, chlorite phyllite bands. The depositional environment of Vangorda formation appears to be relatively deep water.

Vangorda rocks conformably interleave with overlying Menzie Creek volcanics. This formation, with a maximum thickness of $1.5 \mathrm{~km}$, is a metavolcanic unit compositionally similar to the Vangorda except it has well developed volcanic structures such as pillow flows, amygdaloidal basalts and volcanic breccias. This unit is dated by the presence of graptolites in an overlying unit to be early Ordovician or older and is equivalent to rocks of the Road River Formation.

Units equivalent to the Earn Group are represented on both sides of the Anvil Arch by phyllitic chert and stratiform barite with chert conglomerates. 


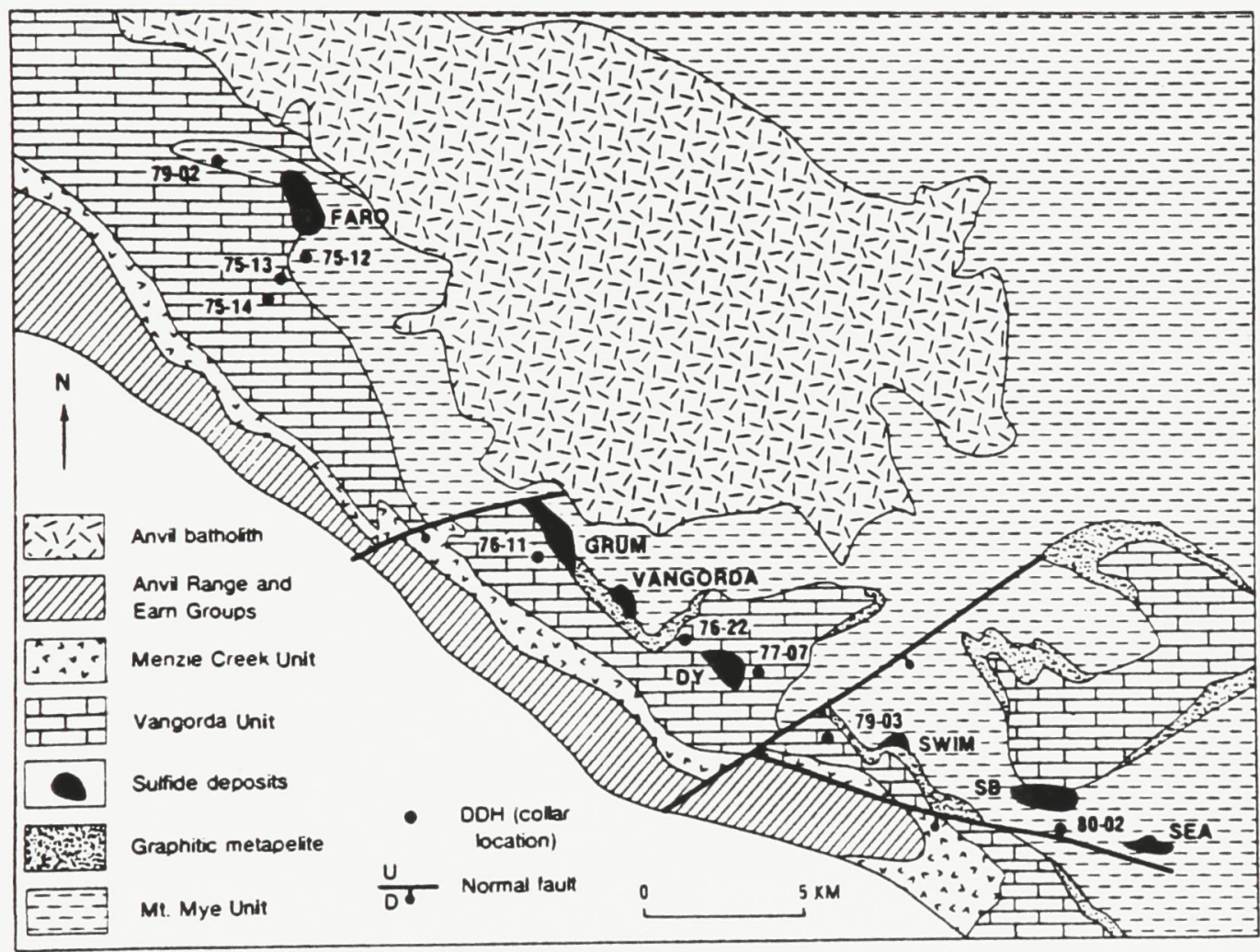

Figure 4. Geologic map of the Anvil $\mathrm{Zn}-\mathrm{Pb}$-Ag district showing surface projections of sulphide mineral deposits (after Jennings and Jilson 1986). 
The latest unit in the district is the Pennsylvanian-Permian Anvil Range Group consisting of red and green chert overlain by massive, dark green basalt. The unit is closely related to a zone of ultramafics which are included in the unit (Jennings and Jilson 1986).

Intrusives

Three major intrusions are recognized, namely: the Anvil Batholith, the Orchay Pluton and the Marjorie Pluton. The rocks are granitic to granodiorite in composition and are late to post-metamorphic. The Anvil Batholith crosscuts and therefore postdates the major deformations. There is little evidence of contact metamorphism. The batholith has been $\mathrm{K} / \mathrm{Ar}$ dated at 95 to $100 \mathrm{Ma}$.

Structure and Metamorphism

The overall structure of Anvil District rocks consists of a northwest trending culmination of metasediments cored by the Anvil Batholith. The flanks of the dome shallowly dip away on either side of the core at about $20^{\circ}$.

The rocks of the Anvil District suffered at least five stages of deformation, denoted $D_{1}$ to $D_{5}$, of which the first two were accompanied by regional metamorphism (Jennings and Jilson 1986). In general, metamorphism increases with depth in the stratigraphy although isograds cut across stratigraphy locally. Metamorphism decreases in intensity radially outward and upward from the Anvil Batholith. However, this is coincidental, as the batholith crosscuts metamorphic isograds thus indicating the metamorphic events 
clearly predate the intrusion (Tempelman-Kluit 1972). The coincidence may be explained by the uplifting of the metasediments during intrusion of the batholith exposing the adjacent, older Mt Mye Formation which is of amphibolite grade.

Amphibolite facies rocks, represented by Mt. Mye formation, show compositional banding, $S_{0}$, and schistosity $S_{1}$, related to $D_{1}$, commonly sub-parallel to each other. $S_{2}$ is axial planar to isoclinal folds of $S_{1}$ and both $S_{0}$ and $S_{1}$ are transposed into $S_{2}$ along the flanks of $D_{2}$ folds. Lineations formed during $D_{2}$ are sub-parallel to the elongation of the Faro deposit which is hosted by Mt. Mye Formation. The predominant fabric of Mt. Mye rocks is $\mathrm{S}_{2}$, which dips about $20^{\circ}$ to the southwest near the Faro deposit. This deformation has been dated as Lower Upper Cretaceous based on cross-cutting relationships with Anvil Batholith.

The overlying Vangorda Formation as well as most of the rest of the district is greenschist facies. Near the Vangorda deposit the $S_{1}$ foliation in rocks of the Vangorda Formation is steeply southwest dipping. These rocks do show transposition of the bedding into the $S_{2}$ foliation although in many cases the bedding is at large angles to the foliation. The Menzie Creek and younger units are characterized by sub-greenschist facies deformation.

\section{THE ORE DEPOSITS}

Genetic model

The zinc-lead deposits of the Anvil District are classified as the sediment-hosted, stratiform type. These deposits are thought to have been formed by exhalation of hot 
metalliferous brines into local depressions on the sea floor in an euxinic environment (Large 1980, 1983; Lydon 1983; Goodfellow 1987). The Anvil deposits display sedimentary textures such as delicate bands and laminations, interlayering of sulphides with unmineralized metasedimentary rocks, interlayering with slump breccias, and sheetlike tabular morphology. They do not have a strong spatial affiliation to volcanic rocks. The arcuate alignment of the deposits suggests fault-controlled deposition (Jennings and Jilson 1986). Isotope work has shown that the sulphur is derived from biogenicallyreduced coeval seawater sulphate (Campbell and Ethier 1974, Goodfellow 1987, and Shanks et al 1987). The source of the lead is mostly crustal, most probably from the underlying strata or basement (Goodfellow and Jonasson 1984).

\section{Sulphide lithology}

There are numerous sulphide lithofacies recognized in the Anvil deposits. However the same facies appear in all the deposits indicating a common origin (Jennings and Jilson 1986). There are two major divisions of sulphide ore types: disseminated quartzose and massive. The former is subdivided into a ribbon-banded graphitic pyritic quartzite and a pyritic quartzite; the latter into a pyritic, baritic and a pyrrhotitic facies. A more detailed and systematic classification of the ore is given in Appendix 1.

A cyclical arrangement, in both the vertical and lateral sense, of sulphide lithofacies, first recognized in the Faro deposit, is common to all deposits and is called the Anvil Cycle (Jennings et al 1980). It consists of a base of ribbon-banded graphitic pyritic quartzites, succeeded by pyritic quartzites, massive pyritic sulphides and lastly 
baritic pyritic sulphides. A sericitic alteration overprint is found in the surrounding host rock of all deposits but is best developed in the footwall.

\section{Faro Deposit}

This world class deposit, $2000 \mathrm{~m}$ long, $1000 \mathrm{~m}$ wide and $30 \mathrm{~m}$ thick, is composed of a single main horizon and a minor upper horizon 10 to $20 \mathrm{~m}$ above the main horizon. The deposit is stratigraphically $100 \mathrm{~m}$ below the Mt. Mye-Vangorda contact and is oriented in a north-west south-easterly direction (Figure 5). In cross section it is slightly skewed to the north east (Figure 6).

Amphibolite metamorphic facies is indicated by andalusite, staurolite, and garnet in the Mt. Mye host rocks. As well, the presence of large recrystallized pyrite grains and rounded inclusions within some pyrite grains (poikilitic texture) indicate grain growth in response to metamorphism (Vokes 1969, Tempelman-Kluit (1970)). Where diorite dykes and plugs intruded the deposit contact metamorphism reverted pyrite to pyrrhotite and magnetite (Jennings and Jilson 1986). The central section of the deposit is a graben bounded by two post- $\mathrm{D}_{2}$ normal faults.

Although on a small scale the orebody displays the Anvil cycle repetitively and to varying degrees of completeness, taken on a large scale the whole ore body forms a single Anvil megacycle from bottom to top (Jennings and Jilson 1986). The facies distribution is also skewed in the longitudinal direction toward the northwest.

The megacycle is reflected in the general metal zoning observed in the orebody. The quartzose sulphide facies at the base are enriched in zinc whereas the upper massive 


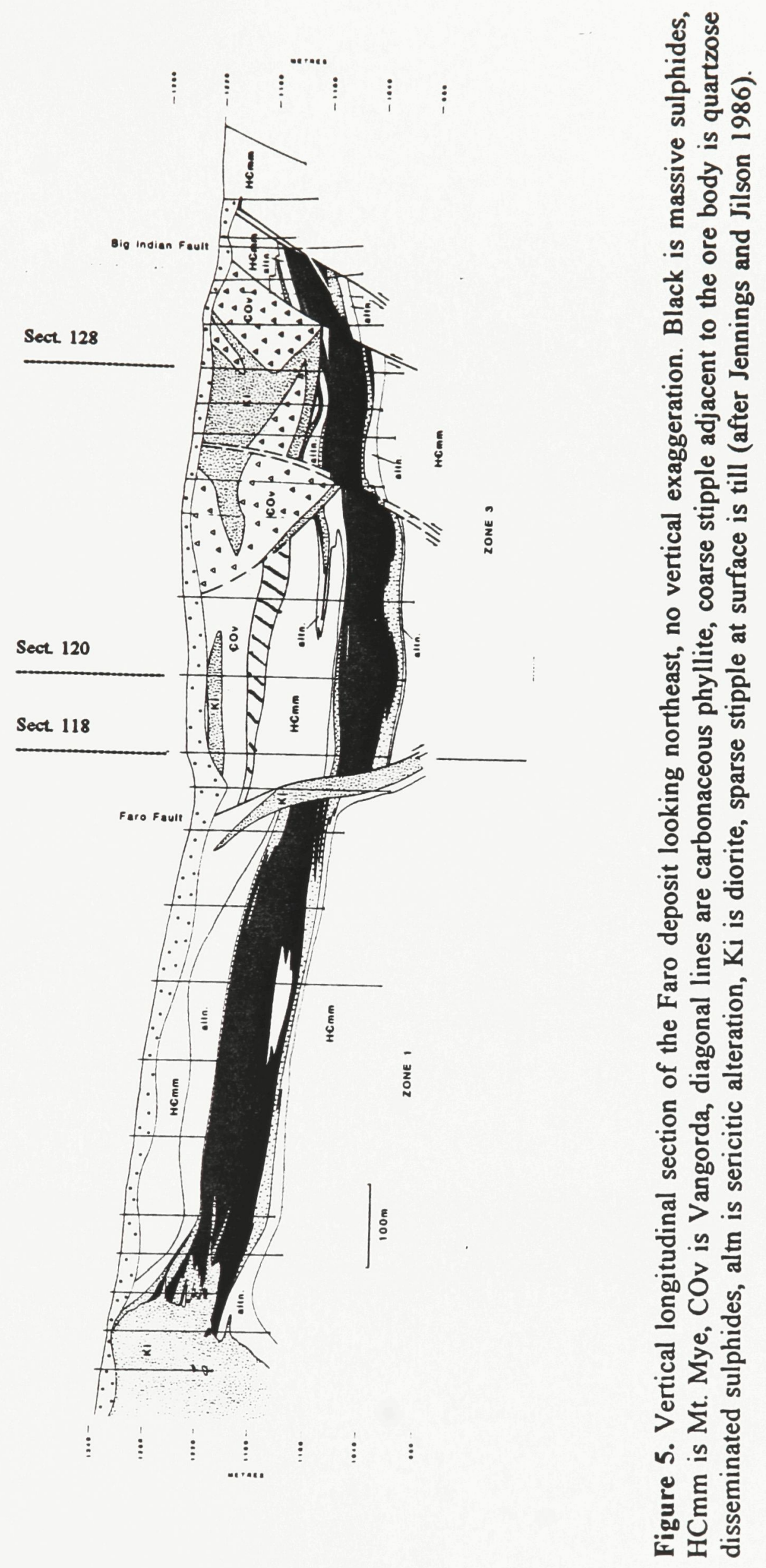




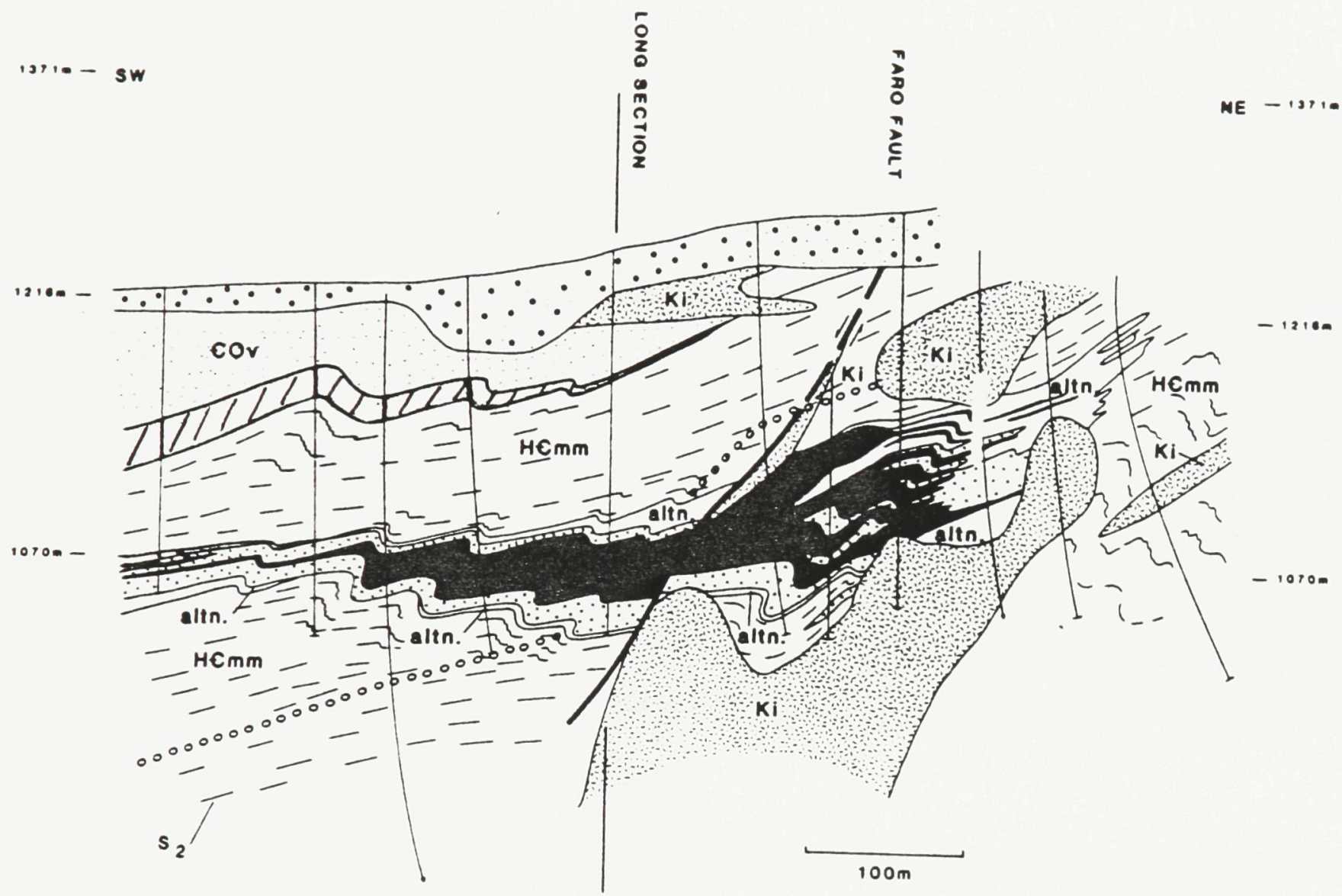

Figure 6. Vertical cross section 118 of the Faro deposit looking northwest, no vertical exaggeration. Units are same as Figure 7. The dotted line approximates the first appearance of staurolite in Mt. Mye (after Jennings and Jilson 1986). 
sulphide and baritic facies are enriched in lead, silver and barium.

\section{Vangorda Deposit}

The deposit is quite shallow, subcropping beneath glacial till in most places. Locally, the basal overburden and uppermost bedrock are cemented by iron oxides.

Stratigraphically, the Vangorda deposit is positioned from the base of the Mt. Mye-Vangorda contact to 50 to $120 \mathrm{~m}$ below. It is $1000 \mathrm{~m}$ long, $200 \mathrm{~m}$ wide and $25 \mathrm{~m}$ thick and consists of two principal horizons, called the main and the upper, and numerous smaller ones separated by barren phyllite waste (Figs 7 and 8). The main horizon, which is stratigraphically equivalent to the Faro deposit, is 50 to $120 \mathrm{~m}$ beneath the basal member of the Vangorda formation. On the basis of the orientation of the Anvil cycles and stratigraphy it is thought that the main portion of the deposit is overturned. The orebody which occurs in the hinge of a large fold has the overall shape of the number " 3 " in cross section (Jennings and Jilson 1986).

The deposit consists of two major ore types: a baritic and a pyritic quartzite facies. The ribbon-banded graphitic pyritic quartzite facies is a minor type and all the other ore types found in the Faro deposit are negligible. Previous work indicates gold values up to $1 \mathrm{ppm}$ and the gold is associated with the pyritic quartzites in the stratigraphic hanging wall (Jennings and Jilson 1986). Greenschist metamorphic facies is evident in the host rocks. Intrusive rocks are negligible and no contact metamorphism is evident. 

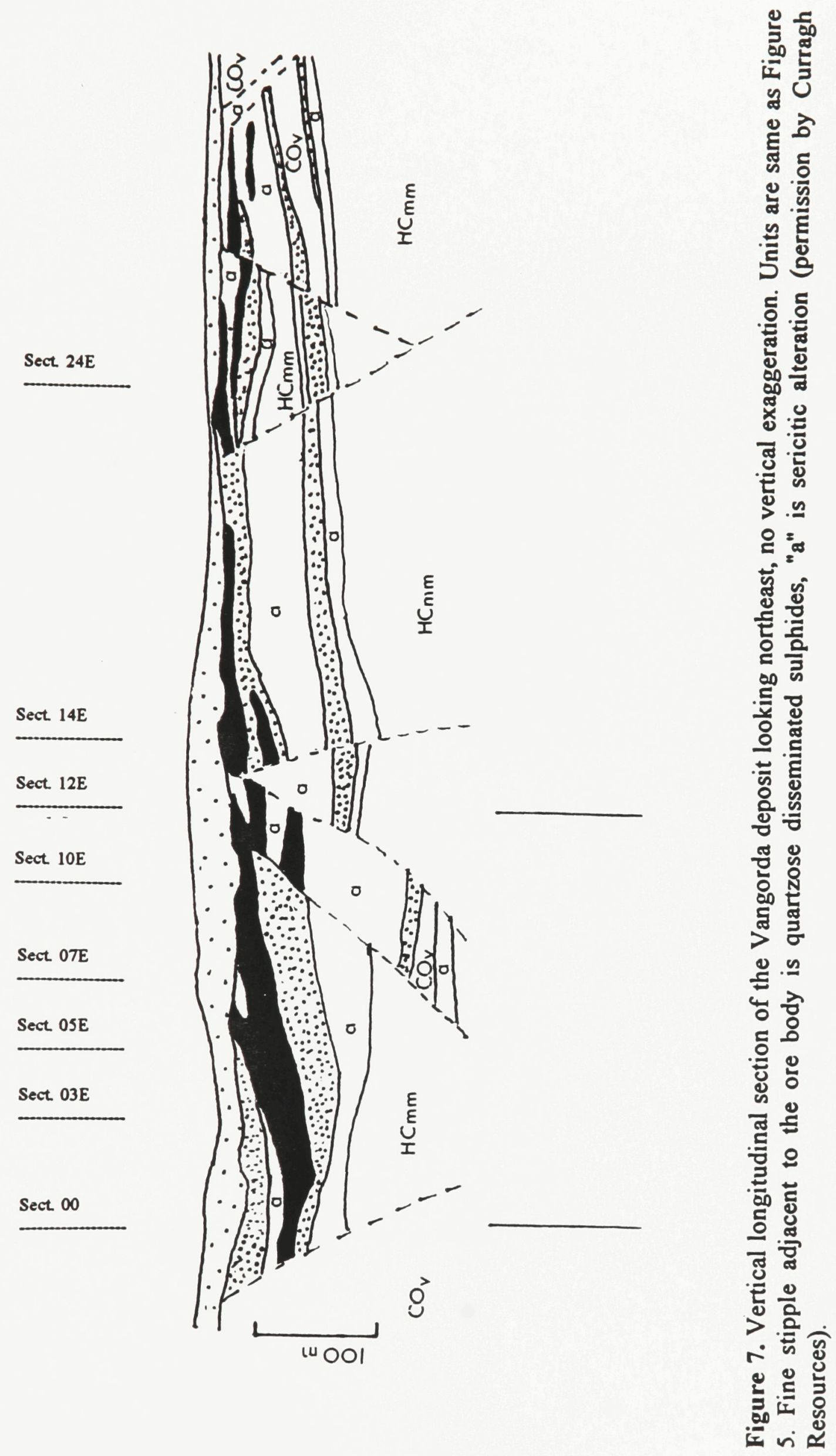

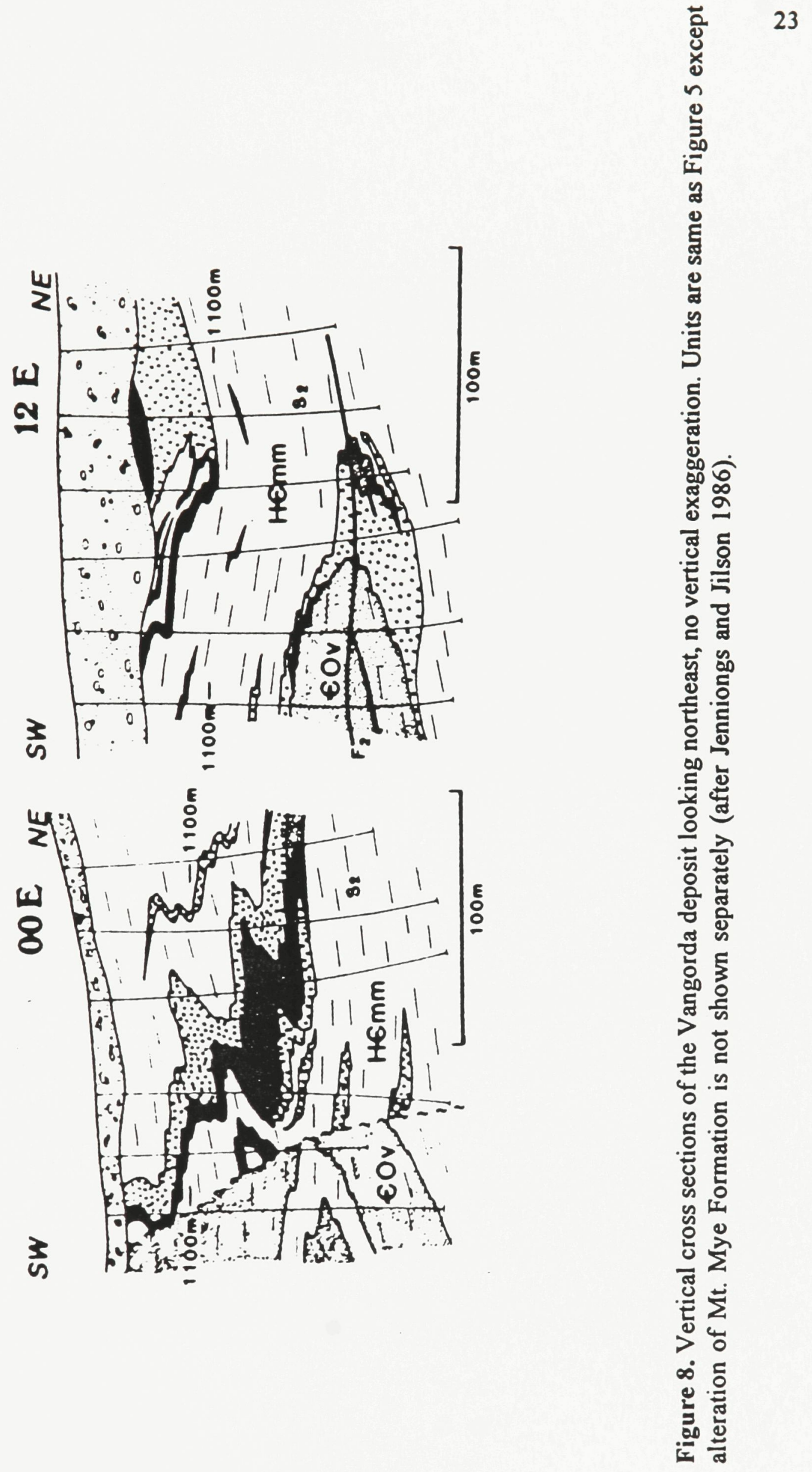


\section{CHAPTER 3}

\section{METHODOLOGY}

\section{SAMPLING AND SAMPLE PREPARATION}

Faro Ore

Representative samples of the five major ore types of the Faro deposit were taken from drill core of cross sections 120 and 128 (Appendix 2). These two cross sections were selected not only because they contained the complete ore suite from the middle of the ore body but also because the concentrator feed, as sampled in this study, was derived from those sections. As well, unlocated hand samples of each of the major ore types were obtained from the mine pit near section 118. From these samples, polished sections and polished thin sections were made. A composite was made of each of the major ore types. The composites were split by means of a spinning riffler into microsamples for mounting in polished sections.

Vangorda Ore

Ten core samples of the Vangorda deposit were taken from sections 3E, 11E, 12E, $17 \mathrm{E}$ and $21 \mathrm{E}$ (Appendix 3). From these some polished sections were made as well as a composite of each of the major ore types. The composites were made by crushing the core to -20 Mesh and then grinding to -200 Mesh. Each sample was sieved at 400 Mesh and each sieve fraction was split by means of a spinning riffler into microsamples for mounting in polished sections. In addition, eighty two polished and polished-thin sections 
of the deposit were provided by Curragh Resources. These sections were made from representative core samples selected by company geological staff (Appendix 3).

\section{Faro and Vangorda Concentrator Products}

The lead and zinc flotation circuits were sampled twice. The first sampling campaign took place on August 19, 1987 during a four hour period while the feed to the concentrator was Faro ore. The second sampling campaign took place on December 15, 1990 while the feed to the concentrator was Vangorda ore. All sampling was performed incrementally every 15 to 30 minutes using sampling cutters supplied by Curragh. In all, twenty nine concentrator samples of Faro ore and forty two concentrator samples of Vangorda ore were taken. Since the concentrator flowsheet was altered between the two sampling campaigns some of the samples of Faro and Vangorda ores are not equivalent.

All pulp samples were collected in buckets, filtered, dried, split, and one split assayed. The other split of each of the Faro concentrator samples was sieved at 75 and $38 \mu \mathrm{m}$ for subsequent image analysis. This top sieve size was selected because the primary grind for Faro ore is $80 \%$ minus $75 \mu \mathrm{m}$. Each sieved fraction was subsampled again by means of a spinning riffler and a polished section was made from the subsample. Selected Vangorda concentrator samples were cyclosized and others were sieved at 53 and $38 \mu \mathrm{m}$. This top sieve size was selected because the primary grind for Vangorda ore is $80 \%$ minus $53 \mu \mathrm{m}$. A subsample of each of the concentrator samples of Vangorda ore was obtained by riffling and a polished section was made of each. 


\section{CHEMICAL ANALYSIS}

Ores

Each composite of the major ore types from each deposit was assayed for Ag, As, $\mathrm{Au}, \mathrm{Ba}, \mathrm{C}_{\mathrm{g}}, \mathrm{C}_{\text {org }}, \mathrm{Cd}, \mathrm{Cu}, \mathrm{Fe}, \mathrm{Hg}, \mathrm{Mn}, \mathrm{Pb}, \mathrm{Sb}$, and $\mathrm{Zn}$. Au was determined by fire assay followed by atomic absorption with a relative precision (20) ranging between 2 and $5 \%$ for the values reported. $\mathrm{Pb}, \mathrm{Zn}, \mathrm{Fe}$, and $\mathrm{Cu}$ were determined volumetrically with a relative precision ranging from 1 to $5 \%$ for the values reported. $\mathrm{As}, \mathrm{Ba}, \mathrm{Cd}, \mathrm{Hg}, \mathrm{Mn}$ and $\mathrm{Sb}$ were determined by inductively coupled plasma - atomic emission spectroscopy (ICP-AES) with a relative precision of 5 to $10 \%$ for the values reported.

$\mathrm{C}_{\mathrm{g}}$ and $\mathrm{C}_{\mathrm{org}}$ were determined by burning the samples in an induction furnace. The resultant $\mathrm{CO}_{2}$ was measured and total carbon determined directly. Carbon due to carbonate minerals is determined as the difference between total carbon and the carbon remaining after leaching with hot $\mathrm{HCl}(20 \%)$. The carbon remaining after leaching is then dried and ignited at $600^{\circ} \mathrm{C}$, the carbon remaining is graphite. Organic carbon is determined by difference. The relative precision of the method is 5 to $10 \%$ for the range of concentrations reported (Analytical Services Group, 1995).

\section{Concentrator Products}

Each concentrator sample of Faro and Vangorda ores were assayed for $\mathrm{Pb}, \mathrm{Zn}, \mathrm{Cu}$, $\mathrm{Ag}, \mathrm{Au}$ and $\mathrm{Sb}$. Assays of $\mathrm{Pb}, \mathrm{Zn}, \mathrm{Ag}$ and $\mathrm{Cu}$ were supplied by Curragh Resources for the concentrator samples of Faro ore. Samples of the concentrator feed of each ore was assayed for $\mathrm{C}_{\mathrm{g}}$ (graphite) and $\mathrm{C}_{\text {org }}$ (organic carbon). 


\section{ORE MICROSCOPY AND X-RAY ANALYSIS}

An optical examination of each of the polished sections and polished-thin sections of the Faro and Vangorda core and concentrator samples using a petrographic microscope was performed to identify minerals and to note specific ore textures. Confirmation of the identity of selected mineral grains was performed by means of X-ray diffraction.

\section{IMAGE ANALYSIS}

Image analysis was performed using the microprobe-scanning electron microscopeimage processing system (MP-SEM-IPS) developed at CANMET by Petruk (1988a). The system consists of a JEOL 733 microprobe with scanning capability, a TRACOR NORTHERN 2000 energy dispersive X-ray analyzer (EDXA), and a KONTRON image analyzer. The image analyzer is capable of controlling the movement of the stage, steering the electron beam and controlling the EDXA.

The back-scattered electron image produced by the scanning electron microscope is digitized before analysis. The minerals appear in various shades of grey which is a function of the average atomic number of the elements which constitute the minerals. Minerals which have a high average atomic number appear brighter than those having a lower average atomic number. Once the grey level range of each mineral in a sample is established, the various minerals may then be identified thereafter automatically for that sample. In the case where two minerals have the same grey level they may be discriminated automatically by means of EDXA.

After mineral discrimination is completed, the features in the image are defined 
and their parameters are measured. These features are grains and binary and ternary particles. A grain consists of one mineral whether it be free or embedded in unbroken ore. A particle is a fragment of broken ore which may contain one or more minerals. If a particle contains only one mineral it is referred to as a free particle or a grain. If a particle contains two minerals it is a binary particle and if a particle contains three minerals it is a ternary particle. Particles which contain more than three minerals are grouped with the ternaries for simplicity. The parameters are areas of features, grain boundaries, areal fractions for minerals in each particle (liberation) and mineral associations.

The area occupied by each mineral in the image is used to calculate the modal analysis directly. This follows from the basic stereological relationship that the volume fraction a randomly distributed phase occupies in 3-dimensionsal space is equivalent to the areal fraction it occupies in a randomly oriented 2-dimensional section of that space (Underwood 1970). This is expressed as:

$$
\mathbf{V}_{\mathbf{v}}=\mathbf{A}_{\mathrm{A}}
$$

where $V_{v}$ is the volume of the phase per unit volume of the test space and $A_{A}$ is the area of the phase per unit area of the test section.

The area of each grain of a given mineral as it appears in a polished section of unbroken ore is used to calculate the grain size distribution for that mineral (Petruk 1989). This is done by assigning to each grain a size equal to the side of a square of equivalent area. This approach gives only an approximation because the true size distribution can not be measured in two dimensions. Various methods for calculating the size distribution from 
2-dimensional data have been developed but they all assume the grains have a simple and uniform shape, such as spheres or cubes. Exact methods for handling grains of irregular shapes have yet to be developed. It has been shown by Petruk (1978) in a study using irregular-shaped sized particles that the size distribution measured by an image analyzer in a mounted polished section is very close to the actual sieve size distribution if the particles are more or less equidimensional and have a wide size distribution (at least five Tyler mesh size intervals).

An alternative technique for measuring grain size distributions is by means of chord size analysis (Petruk 1989). This approach is used only where grains cannot be discriminated because the mineral grains form a continuous matrix or veinlets. The grain size distribution of such a mineral, if based on area, would be unrealistic. Chord analysis requires that chords of the mineral of interest be generated by superimposing a spaced set of horizontal lines on the image of the mineral grains of interest. A chord starts and ends where a line intercepts a mineral grain boundary. The distribution of the chord lengths is taken as an estimate of the mineral's grain size distribution. In general, as for the area method of sizing the sizes will be slightly finer-grained than the true size distribution. Where several grains of the same mineral are clustered together a grain separation technique was used if the grain boundaries were detectable (Petruk 1989). For pyrite the grain edges were detectable. For quartz and sphalerite they were not detected. Nevertheless, in the case of sphalerite in the Faro and Vangorda ores, the grains were mostly present as individuals and as strings of grains but rarely as clusters.

The liberation of sphalerite, galena and pyrite by grain sizes was determined by 
classifying each particle in which the mineral of interest appears according to the areal proportion the mineral occupies in the particle (particle grade or class). A more complete discussion on the problems associated with measuring liberation is given in chapter 5 on the Faro concentrator.

The mineral associations of sphalerite and galena are measured by two methods. In broken ore, the mineral of interest will occur in either free, binary or ternary particles. The first method determines the weight distribution of the mineral of interest among the free, binary and ternary particles in which it is found. The second method is discussed in the next section.

Microprospecting for trace Ag- and Au-bearing minerals was performed on selected samples. This consisted of scanning a polished section at high magnification. A magnification of $300 \mathrm{X}$ was used for locating Ag-bearing minerals by means of a combination of grey-level and EDX discrimination. EDX analysis was necessary to discriminate between barite and tetrahedrite, which have overlapping grey levels in the backscattered-electron image. The location of each Ag-bearing grain so found was recorded automatically for manual checking later. The typical detection limit is about 1.3 $\mu \mathrm{m}$. Ag-bearing grains as small as $3 \mu \mathrm{m}$ were actually detected. A magnification of $400 \mathrm{X}$ was used for locating Au-bearing minerals in Vangorda ore by means of a combination of grey-level and WDX discrimination. WDX dot mapping was necessary to discriminate between gold and galena, which may have overlapping grey levels in the backscatteredelectron image. The location of each Au-bearing grain was recorded automatically for manual checking later. Au-bearing grains as small as $1 \mu \mathrm{m}$ may be detected. Over one 
hundred thousand particles could be examined automatically during a twelve hour period by this method.

It must be noted that the image analysis system can resolve objects to a minimum size of about $1 \mu \mathrm{m}$ at $400 \mathrm{X}$. Therefore, except where stated, all the data and discussion in this work refer only to observations on grains larger than $1 \mu \mathrm{m}$.

Each sample of the ore composites was analyzed for mineral quantities. Also several polished sections of each major ore type of each deposit were selected for measurement of ore mineral grain size distributions by chord analysis and associations of the ore minerals. Image analysis was performed on each polished section of the concentrator samples to identify minerals and measure mineral quantities, ore mineral liberations and ore mineral associations.

\section{MINERAL ASSOCIATIONS BY PERIMETER}

The second method of determining mineral associations was developed during this work. The method was used to quantify mineral associations, including mineral associations by grain size, and to indicate preferential associations of minerals in unbroken ore. In broken ores the method provides direct evidence for preferential breakage and indicates the relative breakage strengths of intergranular boundaries of mineral pairs.

The length of the contact perimeter of any particular mineral with all other minerals in the image gives directly the mineral associations. This follows from the basic stereological relationship that the fraction of surface area any particular mineral has in 
contact with another mineral in 3-dimensionsal space is equivalent to the length fraction that contact occupies in a random 2-dimensional section of that space (Underwood 1970). This is expressed as:

$$
S_{v}=4 / \pi L_{A}
$$

where $\quad S_{V}$ is the contact surface area of the mineral per unit volume of the test space, and

$L_{A}$ is the contact perimeter length per unit area of the test section

An estimate of the absolute measurement reproducibility $(2 \sigma)$ was obtained from replicate measurements made on different polished sections of unbroken ore. For unbroken ore it is approximately $5 \%$ for the measurements in the range 0 to $10 \%$; and approximately $15 \%$ for the range 10 to $100 \%$. For unbroken plant feed the errors are estimated to be $5 \%$ in the range 0 to $10 \%$, and $10 \%$ for the range 10 to $100 \%$. For broken ore the magnitudes of the measurement errors are estimated to be about half of those given for unbroken ore.

\section{To determine mineral associations in unbroken ore:}

measure the length of the perimeter of the mineral of interest adjacent to each of the other minerals in the ore to determine the percentage of its perimeter that is in contact with each of the other minerals. This establishes the mineral associations of the mineral of interest and is a basis for determining preferential breakage.

To determine the mineral associations in unbroken ore as a function of grain size: 
1. discriminate by grey level with the image analyzer only the grains of the mineral of interest and then subdivide into grain size intervals using appropriate image analysis routines.

2. measure the mineral associations of each size interval. These data allow the detection of preferred association by size which may be missed by visual observation. Textures such as fine-grained disseminations of an ore mineral which indicates possible ore refractoriness can thus be detected.

To determine preferred associations in unbroken ore:

1. measure the perimeters of all the mineral grains in the ore except the mineral of interest to determine the percentage of perimeter that is available to the mineral of interest in the ore matrix. This establishes the expected mineral associations of the mineral of interest if it were randomly distributed among the ore matrix. It is the basis for determining preferred mineral associations.

2. compare this expected mineral association for random distribution of the mineral of interest with the actual mineral association to determine if preferred mineral associations exist in the unbroken ore for the mineral of interest.

Preferred mineral associations are indicated by any deviations, in a positive or negative sense and in relative magnitude, of the associations of the mineral of interest from the expected random distribution. These deviations may be conveniently expressed by an index of preferred association where:

$$
\text { INDEX }=\{(\% \text { observed association }) /(\% \text { expected association })\}-1
$$

A positive index indicates preferred association whereas a negative index indicates a non- 
preferred association. This index is shown in the bottom line of the tables of perimeter associations of unbroken ore in chapters 4 and 6.

\section{To determine mineral associations in broken ore:}

measure the length of the perimeter of the mineral of interest adjacent to each of the other minerals in the ore to establish the percentage that is in contact with each of the other minerals.

This establishes the mineral associations of the mineral of interest after breakage and is a measure of the intergranular surface that is unaffected by breakage. In broken ore a portion of the total perimeter of the grains of the mineral of interest may not be adjacent to another mineral but is exposed. This perimeter represents either transgranular or intergranular breakage or some combination of both.

To determine preferential breakage:

1. use the mineral associations in the unbroken ore as a basis and

2. use the mineral associations in the broken ore as a comparison.

3. If the association with another mineral in broken ore is higher than in unbroken ore then preferential association is indicated. This indicates that intergranular surface between the two minerals has increased relative to that of the other minerals. This implies stronger bonding between the two minerals. Conversely, if the association is lower then weaker bonding is indicated and therefore preferential breakage between those minerals has occurred.

If only transgranular (random) breakage occurred then the proportions of the 
intergranular perimeter remaining in the broken ore must be the same as that of the unbroken ore and all the minerals would have the same bonding strength. The relative gain or loss of the proportion of intergranular surface of mineral pairs is a measure of the relative strength or weakness of their intergranular bonds.

These deviations may be conveniently expressed by an index of preferred breakage where:

$\operatorname{INDEX}=\{(\%$ normalized association in broken ore $) /(\%$ association in unbroken ore $)\}-1$ A positive index indicates non-preferred breakage whereas a negative index indicates preferred breakage. This index is shown in the bottom line of the tables of associations of broken ore (Table 21 for Faro and Table 45 for Vangorda). A hierarchy of bonding strengths of mineral pairs may thus be determined.

\section{MICROPROBE ANALYSIS}

Microprobe analyses of selected ore and gangue minerals were performed using a JEOL 733 with either energy dispersive (EDS) or wavelength dispersive spectrometry (WDS). The conditions of all analyses are given as footnotes to the appropriate appendices.

\section{DYNAMIC-SIMS ANALYSIS}

Trace element analysis by Secondary Ion Mass Spectrometry (SIMS) was performed under contract by Dr. S. Chryssoulis, at Surface Science Western, to determine the gold and silver content of the ore minerals and to allow calculation of the precious 
metal distribution in each deposit (Chryssoulis et al 1989; Chryssoulis and Wilson 1990; Chryssoulis 1991). The samples studied were the $+75 \mu \mathrm{m}$ fraction of the lead and zinc concentrates of Faro and Vangorda ores.

\section{MATERIALS BALANCE}

Provided a steady-state condition exists the mass balance principle is that the mass of material entering a mineral processing unit per unit time is equal to that leaving the same unit per unit time. Since it is impractical to measure the mass flow rates of the ore in all the concentrator streams they must be calculated from stream assay data. However the assay data contain errors and therefore do not satisfy the mass balance principle. A solution to this problem is provided by the technique of materials balance with data adjustment based on a least-squares minimization (Wiegel 1972). A beneficial side effect of the data adjustment procedure is that the balanced data have reduced associated error.

A materials balance using measured solid flow rates, pulp densities, particle size distributions, and chemical and mineralogical data derived from the process streams as input was performed by means of the computer program BILMAT (Hodouin and Flament 1985). The balanced data give directly the distribution of the ore minerals in the various process streams of the Faro and Vangorda concentrators.

The mass balance procedure assumes that the standard deviation $(\sigma)$ of each measured flow rate and assay is known because the inverse of the variance $\left(\sigma^{2}\right)$ is used as a weighting factor in the calculation. It is impossible to determine all the standard deviations by measurement because it would require that the concentrator be sampled 
repetitively, each time under identical conditions. In practice the only reasonable substitute for the standard deviations are estimates of the relative errors (Hodouin et al 1988). In order to make reliable estimates it is necessary to be aware of the various sources of error and their relative magnitudes.

Gy (1979) identifies six main sources of error in sampling and analyzing a process stream and provides methods to calculate or estimate their magnitudes. These are: the fundamental error, the segregation error, the weighting error, the materialization error, the sample preparation error and the analytical error. The fundamental error was found to be negligible for all assays except for trace elements which are not used to obtain a balance anyway. The segregation and weighting errors were not evaluated but were minimized by taking the highest number of sample increments of each stream as practical over the longest practical time period. The materialization error was evaluated qualitatively by ranking each sampling point as good $(5 \%)$, fair $(10 \%)$ or poor $(15 \%)$, taking into consideration the type of sampler used, the type of stream discharge and the accessibility to the stream (Hodouin et al 1988). The sample preparation error, non-random error due to human mistakes, was not evaluated. The relative analytical error, which includes errors in sieving, chemical assaying and image analysis, largely depends upon the amount of the particular species present. The relative errors assigned to the chemical assays ranged from 1 to $25 \%$ (Steger 1984) and that of the image analysis data ranged from 1 to $100 \%$ (Petruk 1989). The relative errors due to sieving were taken as $2 \%$ for all samples (Hodouin et al 1988).

The overall relative error assigned to each measured assay was obtained by adding 
the errors due to each source (Gy 1979). The error assigned to the measured feed flowrates were supplied by Curragh Resources.

Balancing of each circuit was performed in two steps due to the wide range of the accuracies of the data and due to the complexity of handling such large amounts of data. The chemical assay, pulp density and sieve data, which have the smallest error, were selected to calculate the overall solid flowrates. In the second step, the calculated flowrates were input as if they were measured flowrates but were protected from adjustment by means of assigning them a very small error (.001\%). The mineralogical and trace element data were then balanced and were thereby adjusted so that they are consistent with the more accurate data. The material balance technique was also used to determine the precious metal distribution in the ore in each process stream.

\section{LEACH TESTWORK}

Diagnostic leach testing was performed on $1 \mathrm{~kg}$. samples of both ores (Chryssoulis and Cabri 1990). The samples were first ground to $80 \%-16 \mu \mathrm{m}$. To passivate any carbon present the samples were first conditioned in kerosene for one hour. Each sample was leached for 48 hours under the following conditions: $33 \mathrm{wt} \%$ solids, $2.0 \mathrm{~g} / \mathrm{L} \mathrm{NaCN}$, $\mathrm{pH}=10.6$. The $\mathrm{pH}$ and $\mathrm{NaCN}$ levels were maintained in the ranges $10.5-10.8$ and $1-2 \mathrm{~g} / \mathrm{L}$ during the test. 


\section{CHAPTER 4}

\section{MINERALOGY OF THE FARO ORE TYPES}

\section{INTRODUCTION}

The ore types, shown in Appendix 1, are defined on the basis of mineralogical content and texture. Only the major ore types relevant to mineral processing are selected for this study; namely, $2 \mathrm{~A}, 2 \mathrm{BCD}, 2 \mathrm{E}, 2 \mathrm{G}$ and $2 \mathrm{H}$. Ore type $2 \mathrm{BCD}$ is a grouping of the individual ore types $2 \mathrm{~B}, 2 \mathrm{C}$, and $2 \mathrm{D}$. These major ore types are used by company mine geologists for purposes of metallurgical grade control.

Fifty located samples were taken by sampling representative drill core from sections 120 and 128 of the Faro deposit (Appendix 2). Each sample was 3 to 6 inches in length. Also one hand specimen of each of the ore types was taken from section 118 in the pit. Thirty four polished sections of drill core and twenty six polished sections of hand samples were made for further examination. From these polished sections three to four of the most representative of each ore type were selected for determination of grain size distributions and associations of the important ore minerals by image analysis. The remainder of the core samples of each ore type was combined, crushed, blended and split. The crushed product for each ore type was then assayed and a modal analysis performed.

Thirty six minerals were identified in drill core and concentrator samples of the Faro ore. The minerals identified are listed in Table 1. Only the important minerals in the Faro ore are described. 
TABLE 1

MINERALS IDENTIFIED IN FARO AND VANOORDA ORES

NAME

ABUNDANCE

SULPHIDES

Pyrite (PY)

Galena (GAL)

Sphalerite (SP)

Pynthotite (PO)

Marcasite

Chalcopyrite (CP)

Acanthite

Digeniter

Covelliter

Bornite"

Chalcociter

SULPHARSENIDES

Arsenopyrite (ASP)

Gersdorffite

Major

Minor

Minor

Minor

Minor

Trace

Trace

Trace

Trace

Trace

Trace

OXIDES

Magnetite (MAG)

Goethite'

Rutile

Cassiterite

Trace

Trace

Trace

Trace

Trace

Trace

SULPHOSALTS

Tetrahedrite-tennantite Trace

Stannite

Trace

METALS AND ALLOYS

Gold-silver

Native silver

Trace

Trace

SILICATES

Quartz (QTZ)

Major

Muscovite (MUSC)

Minor

Biotite

Trace

Amphibole

Trace

Kaolinite

Trace

Celsian

Trace

Gamet

Clinochlore

Trace

Trace

Talc

Zircon

Trace

Trace

CARBONATES

Siderite (SID)

Ankerite (ANK)

Calcite

Rhodochrosite

Kutnohorite

Barytocalcite

Major (Minor in Vangorda)

Trace (Major in Vangorda)

Trace

Trace

Trace

Trace

Trace

OTHER

Dolomite

Minor

Barite

Trace

Apatite

Trace

"Minerals superscripted with an " $\mathrm{f}$ " were found in Faro ore only, those with a " $\mathrm{v}$ " were found in Vangorda ore only. Abbreviations in brackets used in tables. 
Microprobe analyses by EDS of sphalerite taken from the concentrator concentrate and tailings are given in Appendix 3. The sphalerite has an average zinc content of 55.2 $\mathrm{wt} \%$ and an $\mathrm{Fe}$ content of $9.4 \mathrm{wt} \%$. The zinc content provides an upper limit on zinc concentrate grade. Microprobe analyses by WDS of galena in samples taken from the lead concentrate are shown in Appendix 4. High Ag (avg. $=825$ ppm) and Sb (avg. $=923$ ppm) contents were found in galena. No As nor $\mathrm{Bi}$ was found at minimum detection limits of 500 and $1000 \mathrm{ppm}$ respectively. Microprobe analyses by WDS of tetrahedrite are given in Appendix 5. The data show that tetrahedrite contains 5.3 to $29.7 \mathrm{wt} \% \mathrm{Ag}$ $($ avg. $=20.9)$. Electron microprobe analyses by WDS of gold-silver alloy are given in Table 2, and of randomly selected carbonate grains are given in Appendix 6.

\section{TABLE $2^{\circ}$}

COMPOSITIONS OF GOLD-SILVER ALLOY IN FARO ORE

\begin{tabular}{||c|c|c|c|c|c|}
\hline Anal. & 1 & 2 & 3 & 4 & Average \\
\hline $\mathrm{Ag}$ & 34.6 & 35.6 & 36.5 & 40.8 & 36.9 \\
\hline $\mathrm{Au}$ & 65.4 & 62.2 & 62.8 & 58.0 & 62.1 \\
\hline
\end{tabular}

- Accelerating voltage $15.0 \mathrm{Kv}$, beam current $35 \mathrm{nA}$, counting times 100 seconds, standards and X-ray emission lines used are goldsilver alloy with $60 \% \mathrm{Au}$ and $40 \% \mathrm{Ag}$ ( $\mathrm{AuL}$. AgL $)$, ZAF correction applied.

\section{A ORE}

This ore type is described as a ribbon-banded, graphitic, pyritic quartzite. The ore represents the bottom unit of the Anvil Cycle and reflects the characteristics of the Mt Mye schist, with which it interleaves. It is generally low grade and is normally treated as waste rock. The ore consists of light and dark bands from $1 \mathrm{~mm}$ up to $2 \mathrm{~cm}$ thick (Plate 
1). Fourteen polished sections and three polished thin sections of this ore type were made for examination.

The chemical and modal analyses of seven combined core samples of $2 \mathrm{~A}$ ore are found in Tables 3 and 4, respectively. Minẹrals identified, in order of descending abundance, are: quartz, pyrite, muscovite, sphalerite, siderite, galena, marcasite and trace amounts of arsenopyrite, pyrrhotite, chalcopyrite, rutile, kaolinite, apatite, tetrahedrite, zircon and graphite.

\section{TABLE 3}

ASSAYS OF FARO ORE TYPES (WT\%)

\begin{tabular}{|c|c|c|c|c|c|}
\hline & $2 \mathrm{~A}$ & $2 \mathrm{BCD}$ & $2 \mathrm{E}$ & $2 \mathrm{G}$ & $2 \mathrm{H}$ \\
\hline $\mathrm{Zn}$ & 5.9 & 3.5 & 6.5 & 7.1 & 16.7 \\
\hline $\mathrm{Pb}$ & 1.6 & 4.1 & 4.1 & 4.7 & 6.0 \\
\hline $\mathrm{Ag}(\mathrm{ppm})$ & 17.1 & 57.3 & 44.9 & 85.7 & 83.3 \\
\hline $\mathrm{Au}(\mathrm{ppm})$ & 0.21 & 0.17 & 0.14 & 0.14 & 0.27 \\
\hline $\mathrm{Fe}$ & 11.1 & 7.8 & 33.5 & 19.0 & 32.5 \\
\hline $\mathrm{Cu}$ & 0.1 & 0.1 & 0.2 & 0.1 & 0.2 \\
\hline $\mathrm{As}$ & 0.06 & 0.04 & 0.09 & 0.02 & 0.04 \\
\hline $\mathrm{Cd}(\mathrm{ppm})$ & $<100$ & $<100$ & $<100$ & 100 & 100 \\
\hline $\mathrm{Sb}(\mathrm{ppm})$ & $<100$ & 100 & 100 & 100 & 200 \\
\hline $\mathrm{Hg}(\mathrm{ppm})$ & 20 & 30 & 20 & 50 & 100 \\
\hline $\mathrm{Mn}$ & $<0.05$ & 0.05 & 0.1 & 0.1 & 0.1 \\
\hline $\mathrm{C}$ & 0.69 & 0.59 & 0.54 & 0.96 & 0.97 \\
\hline $\mathrm{C}$ & $<0.02$ & $<0.02$ & $<0.02$ & $<0.02$ & $<0.02$ \\
\hline
\end{tabular}

The grain size distributions of pyrite, sphalerite, galena, quartz and chalcopyrite as measured by chord analysis are shown in Table 5 and plotted in Figure 9. Due to the inability of the image analyzer to discriminate quartz grain boundaries, the size distribution of quartz is probably overestimated by about 2 to 3 Tyler mesh size intervals. 


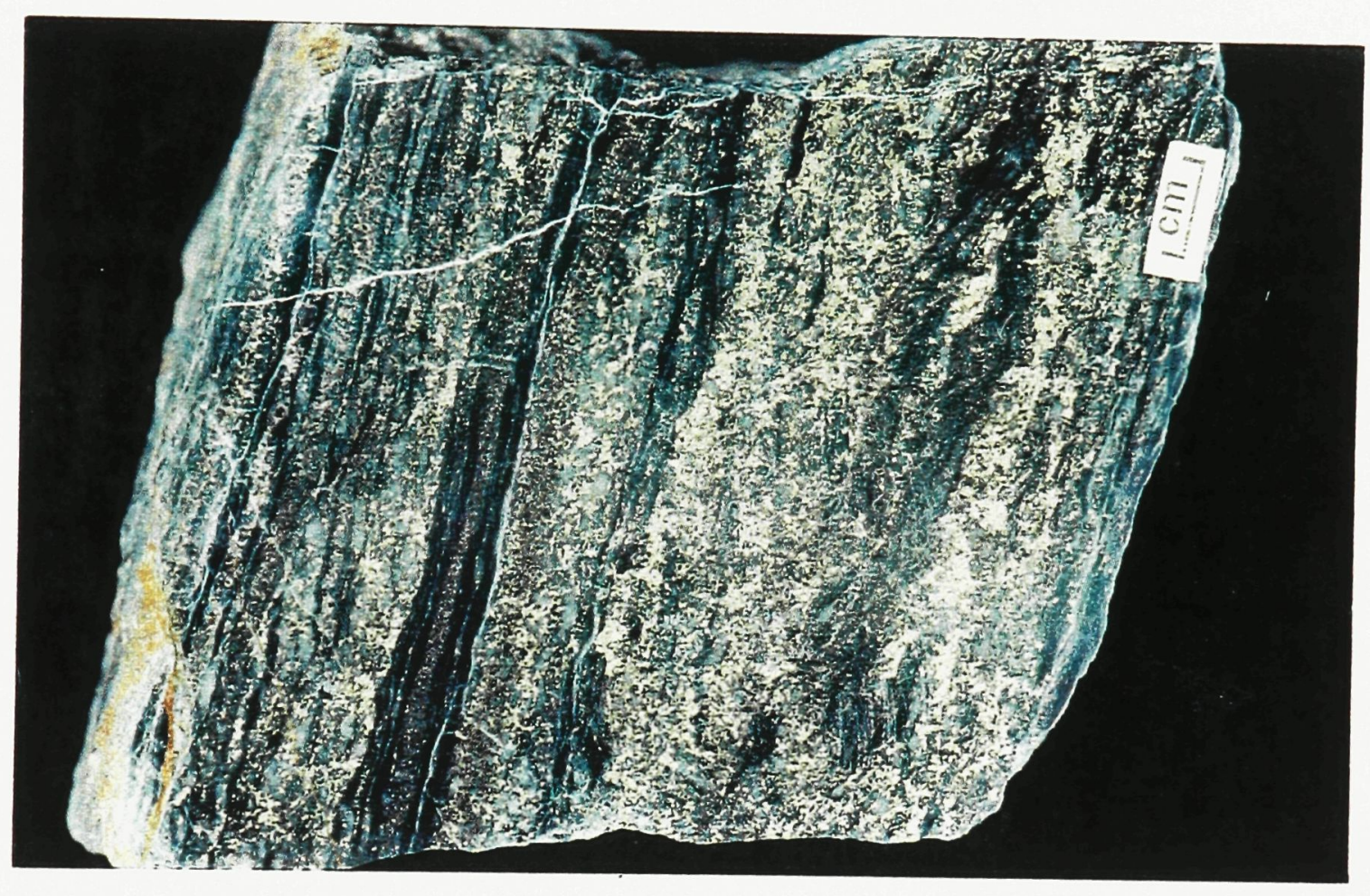

\section{Plate 1}

Photograph showing ribbon-banded $2 \mathrm{~A}$ ore. Black bands of fine-grained quartz are interleaved with light bands consisting of layers of brownish sphalerite and coarse-grained quartz with pale yellow pyrite. 
TABLE 4

\begin{tabular}{|c|c|c|c|c|c|}
\hline & $2 A$ & $2 \mathrm{BCD}$ & $2 \mathrm{E}$ & 20 & $2 \mathrm{H}$ \\
\hline Pyrite & 21.52 & 19.41 & 63.02 & 36.45 & 18.57 \\
\hline Galena & 1.85 & 4.74 & 4.74 & 5.44 & 6.93 \\
\hline Sphalerite & 10.69 & 6.34 & 11.78 & 12.86 & 30.25 \\
\hline Pymhotite & 0.05 & 0.04 & 0.86 & 1.96 & 25.36 \\
\hline Chalcopyrite & 0.05 & 0.06 & 0.05 & 0.11 & 0.03 \\
\hline Arsenopyrile & 0.16 & 0.11 & 0.06 & 0.08 & 0.03 \\
\hline Barite & 0.01 & 0.03 & 1.84 & 28.33 & 0.13 \\
\hline Quartz & 45.70 & 52.60 & 6.31 & 0.68 & 2.14 \\
\hline Muscovite & 15.81 & 8.13 & 0.50 & 0.33 & 0.07 \\
\hline Siderite & 4.16 & 8.40 & 10.50 & 13.76 & 16.49 \\
\hline Magnetite & 0.00 & 0.14 & 0.33 & 0.00 & 0.00 \\
\hline
\end{tabular}

these data were obtained by a combination of assaying and image analysis

"includes minor marcasite; "includes trace kaolinite

includes trace clinochlore, celsian

The mineral associations of sphalerite and galena as measured by the perimeter association technique described in chapter 3 are shown in Table 6 . The data are interpreted according to the principles outlined in that chapter. Galena is closely associated with quartz ( $83 \%$ of its perimeter) and preferential association with quartz is indicated by the higher percentage of its perimeter adjacent to quartz than would be expected if the galena grains were randomly distributed in the ore matrix $(55 \%)$. As discussed in chapter 3 , an index of preferred association is shown in the bottom row of the table to indicate the relative magnitude and sense (positive or negative) of the preferred association of galena with quartz (INDEX=.51). The association of galena with quartz decreases uniformly from $86 \%$ in the $-9+1 \mu \mathrm{m}$ grain size interval to $64 \%$ in the 
TABLE 5

GRAIN SLEE DISTRIBUTIONS FOR FARO 2A ORE (CUMULATIVE \% PASSING)

\begin{tabular}{|c|c|c|c|c|c|}
\hline $\begin{array}{l}\text { GRAN } \\
\text { SLE } \\
(\mu M)\end{array}$ & PY & SP & GAL & $\mathrm{CP}$ & QTZ \\
\hline 3.4 & 0.50 & 1.91 & 34.10 & 1.31 & \\
\hline 4.7 & 0.92 & 3.10 & 4.69 & 1.89 & \\
\hline 6.7 & 1.85 & 7.07 & 59.89 & 3.83 & \\
\hline 9.4 & 3.86 & 16.66 & 72.16 & 8.33 & \\
\hline 13 & 7.07 & 26.70 & 80.13 & 12.98 & 0.38 \\
\hline 19 & 11.57 & 37.24 & 86.40 & 18.40 & 0.79 \\
\hline 26 & 18.12 & 50.20 & 92.36 & 26.92 & 1.44 \\
\hline 38 & 26.87 & 63.34 & 96.69 & 37.02 & 3.16 \\
\hline 53 & 38.87 & 76.50 & 98.99 & 53.22 & 5.02 \\
\hline 75 & 52.57 & 86.94 & 99.33 & 80.72 & 8.35 \\
\hline 106 & 65.13 & 93.37 & 100.00 & 94.42 & 12.82 \\
\hline 150 & 75.28 & 98.49 & & 100.00 & 19.22 \\
\hline 212 & 84.59 & 100.00 & & & 28.10 \\
\hline 300 & & & & & 39.75 \\
\hline 425 & & & & & 54.51 \\
\hline 600 & & & & & 70.35 \\
\hline 850 & & & & & 85.41 \\
\hline
\end{tabular}

$-75+53 \mu \mathrm{m}$ grain size interval. This trend is interpreted as numerical evidence for dissemination of fine-grained galena in quartz matrix. In contrast, the association of galena with sphalerite increases from $2 \%$ for the finest size to $12 \%$ for the $+150 \mu \mathrm{m}$ fraction. This indicates that coarse-grained galena is more closely associated with sphalerite than fine-grained galena is. There is a definite lack of association of galena with sphalerite (INDEX $=-.82$ ) and with muscovite (INDEX $=-.71$ ). 


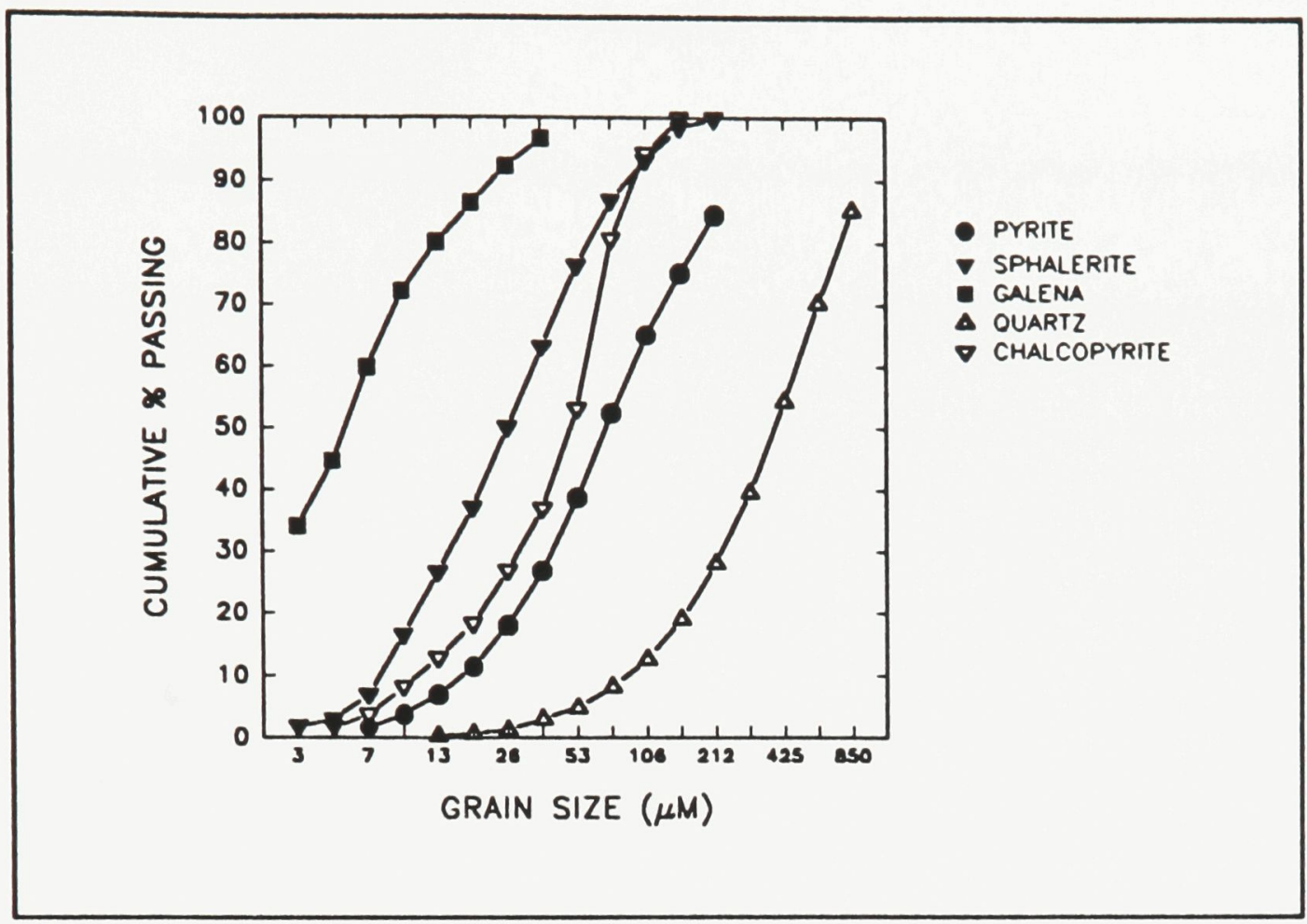

Figure 9 Grain size distributions of ore minerals in Faro 2A ore.

Sphalerite shows not only a close association with quartz (61\%), especially when fine-grained ( $70 \%$ in the $-26+9 \mu \mathrm{m}$ size interval), but also a strong preferential association with pyrite $($ INDEX $=1.14)$. The preferential association of fine-grained galena and sphalerite with quartz is plotted in Figure 10. In that figure, the expected random associations (dotted lines) are also shown for comparison. The data are interpreted as evidence for fine-grained sphalerite dissemination in a quartz matrix. This texture, which was also indicated for galena, suggests that the very fine grind required to liberate sphalerite and galena would be difficult because a significant portion of each mineral is encapsulated in quartz which is refractory. Taking the mineral quantities and mineral grain size data together they show that the ore texture is dominated by coarse-grained quartz and pyrite with fine-grained sphalerite and very fine-grained galena. It is interpreted that 
TABLE 6

MINERAL ASSOCIATIONS OF GALENA AND SPHALERITE IN 2A ORE BY GRAIN SIZE (PERIMETERX)

GALEMA

\begin{tabular}{|c|r|r|r|r|r|r|r|r|}
\hline $\begin{array}{c}\text { GAL GRAIN } \\
\text { SIZE } \\
(\mu M)\end{array}$ & OTZ & SID & PY & CP & QAR & PO & MSC & $S P$ \\
\hline+150 & 88 & 0 & 0 & 0 & 0 & 0 & 0 & 12 \\
\hline+106 & 76 & 0 & 11 & 0 & 0 & 0 & 1 & 12 \\
\hline+75 & 79 & 3 & 2 & 0 & 0 & 0 & 4 & 12 \\
\hline+53 & 64 & 1 & 26 & 0 & 0 & 0 & 3 & 6 \\
\hline+38 & 76 & 6 & 2 & 0 & 0 & 0 & 11 & 5 \\
\hline+26 & 77 & 6 & 10 & 0 & 0 & 0 & 5 & 2 \\
\hline+9 & 82 & 3 & 9 & 0 & 0 & 0 & 4 & 2 \\
\hline+1 & 86 & 2 & 7 & 0 & 0 & 0 & 3 & 2 \\
\hline ALL SIZES & 83 & 3 & 8 & 0 & 0 & 0 & 4 & 2 \\
\hline EXPECTED & 55 & 7 & 13 & 0 & 0 & 0 & 14 & 11 \\
\hline INDEX & .51 & -.57 & -.38 & $n$ & $n a$ & $n$ & -.71 & -.82 \\
\hline
\end{tabular}

SPHALERI TE

\begin{tabular}{|c|r|r|r|r|r|r|r|r||}
\hline $\begin{array}{c}\text { SP GRAIN } \\
\text { SIZE } \\
(\mu M)\end{array}$ & QTZ & \multicolumn{1}{|c|}{ SID } & \multicolumn{1}{c|}{ PY } & \multicolumn{1}{c|}{ CP } & \multicolumn{1}{c|}{ BAR } & PO & MUSC & GAL \\
\hline+150 & 61 & 1 & 27 & 1 & 0 & 0 & 8 & 2 \\
\hline+106 & 53 & 0 & 42 & 0 & 0 & 0 & 5 & 0 \\
\hline+75 & 47 & 1 & 43 & 0 & 0 & 0 & 8 & 1 \\
\hline+53 & 61 & 0 & 33 & 0 & 0 & 0 & 5 & 1 \\
\hline+38 & 61 & 1 & 30 & 0 & 0 & 0 & 7 & 1 \\
\hline+26 & 65 & 0 & 28 & 0 & 0 & 0 & 6 & 1 \\
\hline+9 & 70 & 0 & 23 & 0 & 0 & 0 & 6 & 1 \\
\hline+1 & 32 & 7 & 40 & 2 & 2 & 2 & 15 & 0 \\
\hline ALL SIZES & 61 & 1 & 30 & 0 & 0 & 0 & 7 & 1 \\
\hline EXPECTED & 58 & 8 & 14 & 0 & 0 & 0 & 15 & 5 \\
\hline INDEX & .05 & -.88 & 1.14 & $n$ & $n a$ & $n$ & -.53 & -.80 \\
\hline
\end{tabular}




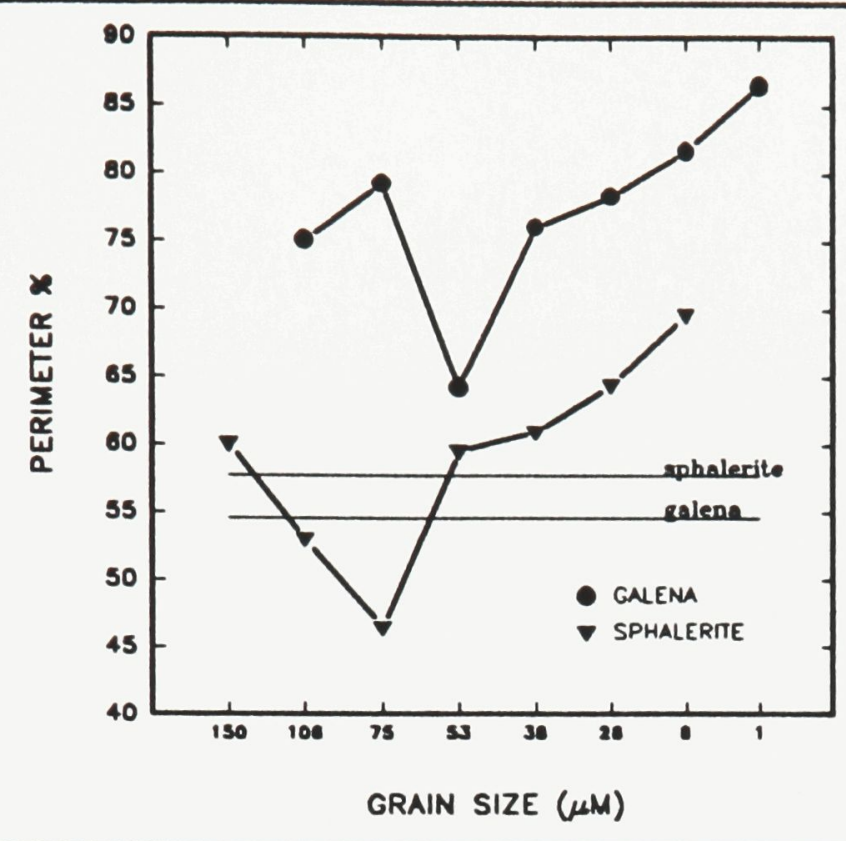

Figure 10 Galena and sphalerite associations with quartz in $2 \mathrm{~A}$ ore showing the increasing associations as grain sizes diminish. Flat lines show expected associations.

a large portion of the galena and a small portion of the sphalerite are disseminated in and closely associated with quartz as minute grains.

The textural interpretation from the image analysis data was confirmed by optical examinations of thin sections. The light bands of $2 \mathrm{~A}$ ore consist predominantly of equidimensional coarse quartz grains, having diameters in the range 200 to $300 \mu \mathrm{m}$. Most of the sulphides are found in the light bands (Plate 2). Fine-grained galena was observed as disseminations in the quartz matrix. Typically, where sphalerite is present in significant amounts it occurs as long irregular bands in the quartz matrix hosting large euhedral to subhedral pyrite grains and also chalcopyrite and galena are interstitial to the pyrite. Thin bands of siderite may also be present in the quartz matrix. Where pyrite is more dominant, sphalerite occurs as smaller grains adjacent to and as rims on, the pyrite. Arsenopyrite, which concentrates in $2 \mathrm{~A}$ ore in the light bands, normally occurs as 


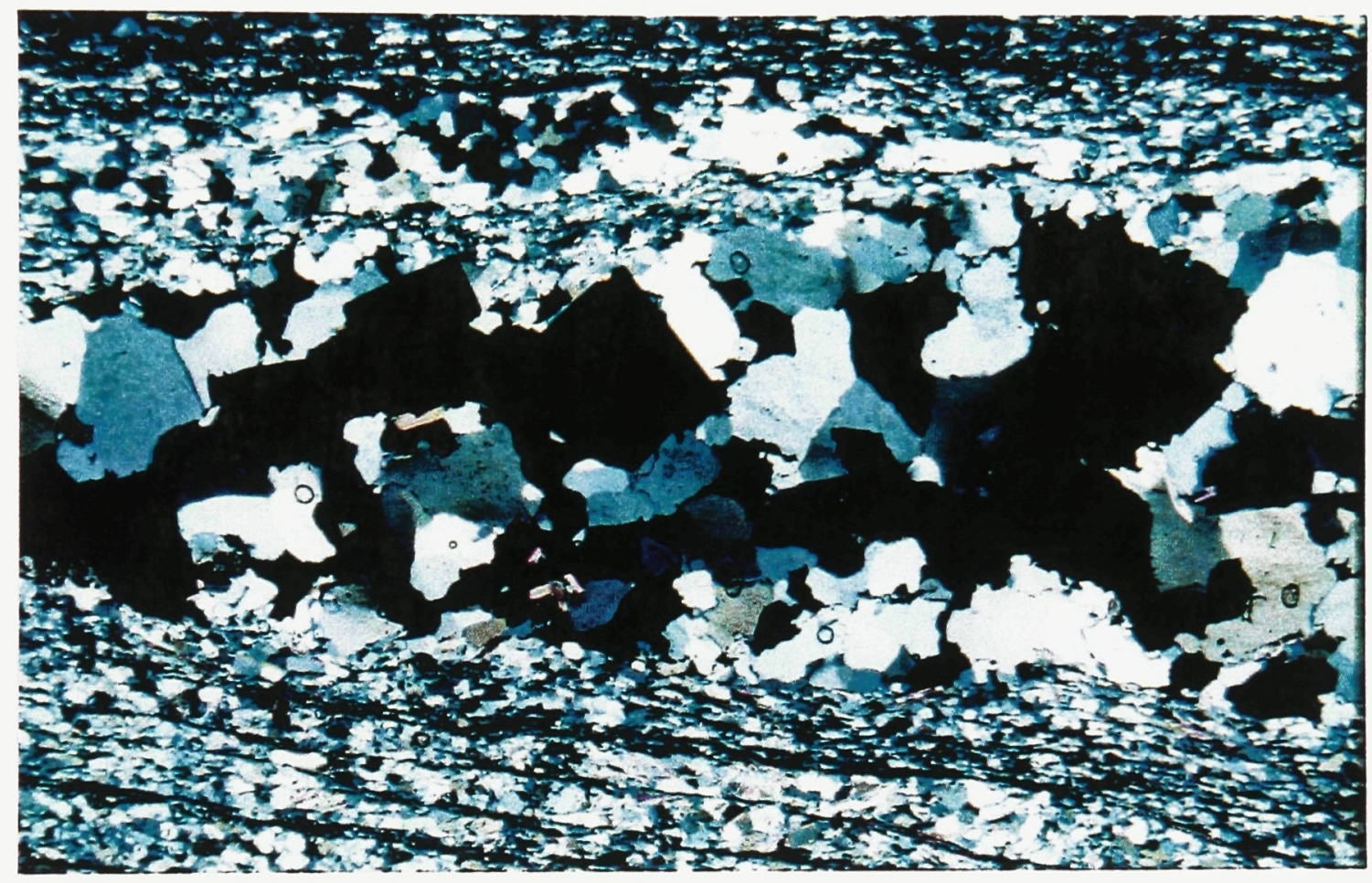

Scale:

$1 \mathrm{~mm}$

\section{Plate 2}

Photomicrograph of $2 \mathrm{~A}$ ore showing a light band as it appears in crossed-polarized transmitted light. The large opaque grains are pyrite and sphalerite associated with coarse quartz. Above and below are the dark bands consisting of fine-grained quartz with dark stringers of muscovite and carbonaceous material. 
individual euhedral to subhedral grains. Some large grains have a core consisting of a single large grain of pyrite.

The dark bands consist mostly of elongated quartz grains which are much smaller than those of the light bands, typically 75 to $100 \mu \mathrm{m}$ in the long direction. Also within the dark bands are often found several closely-spaced stringers of muscovite and less often siderite and pyrite. The average size of the muscovite grains is about $10 \mu \mathrm{m}$. The muscovite stringers are invariably associated with an opaque, presumably carbonaceous, material. Most of the carbonaceous material concentrates in the muscovite stringers and appears under transmitted light as alignments of individual anhedral grains about 1 to 2 $\mu \mathrm{m}$ in size. In reflected light the grains appear dull grey with specks of glassy reflections and show no evidence of anisotropism. This observation may however be due to its finegrained nature. The rest of the carbonaceous material is disseminated in the fine-grained quartz matrix.

The appearance of light and dark bands of the $2 \mathrm{~A}$ ore type is due to the concentration of carbonaceous material in the dark bands. Assay of one hand specimen sample showed that the light bands contained $0.93 \mathrm{ppm} \mathrm{Au,} 0.57 \%$ graphitic carbon and $0.06 \%$ organic carbon whereas the dark bands contain $3.53 \mathrm{ppm} \mathrm{Au,} 1.12 \%$ graphitic carbon and $0.08 \%$ organic carbon. This indicates an association of Au with the graphitic carbon.

\section{BCD ORE}

The pyritic quartzites constitute a group of minor ore types which are generally 
characterized by a low lead-zinc grade, a low pyrite content and an abundance of quartz The group comprises the second ore facies of the Anvil Cycle. The group constitutes approximately $20 \%$ of the Faro orebody. Seven polished sections of this ore type were selected for examination.

The chemical and modal analyses of sixteen combined core samples of $2 \mathrm{BCD}$ ore are shown in Tables 3 and 4, respectively. Due to the high variability of the composition of this ore group the modal analysis of the samples selected shows an unusually high total lead-zinc content. The polished sections examined were also highly variable in total sulphide content which varied from 10 to $70 \%$. Minerals identified in this ore type are, in order of descending abundance: quartz, pyrite, sphalerite, muscovite, siderite, galena, marcasite, magnetite, arsenopyrite, chalcopyrite, pyrrhotite, barite, kaolinite, clinochlore, celsian, monazite, tetrahedrite and silver.

The grain size distributions of pyrite, sphalerite, galena, quartz, and chalcopyrite are shown in Table 7 and plotted in Figure 11. In these ores quartz is the coarsest mineral followed by sphalerite and pyrite. As in $2 \mathrm{~A}$ ore the quartz grain sizes are overestimated by about 2 to 3 Tyler mesh size intervals. Galena is very fine-grained but both galena as well as sphalerite are coarser in the $2 \mathrm{BCD}$ ore than in the $2 \mathrm{~A}$ ore.

The associations of sphalerite and galena as determined by the perimeter technique are shown in Table 8. Galena is closely associated with quartz (55\%), siderite (25\%), and sphalerite $(15 \%)$. Preferential association is indicated with siderite $($ INDEX $=.92)$ and 
TABLE 7

GRAIN SLZE DISTRIBUTIONS FOR FARO 2 BCD ORE (CUMULATIVE \% PASSING)

\begin{tabular}{||c|c|c|c|c|c||}
\hline $\begin{array}{c}\text { GRAIN } \\
\text { SLZE } \\
(\mu \mathrm{M})\end{array}$ & $\mathrm{PY}$ & SP & GAL & CP & QTZ \\
\hline 3.4 & 1.47 & 1.30 & 26.34 & 4.43 & \\
\hline 4.7 & 2.60 & 2.01 & 36.21 & 10.27 & \\
\hline 6.7 & 5.52 & 4.91 & 48.02 & 17.30 & \\
\hline 9.4 & 13.00 & 11.28 & 59.52 & 27.66 & \\
\hline 13 & 21.92 & 18.65 & 68.97 & 40.01 & 0.39 \\
\hline 19 & 32.59 & 26.11 & 76.13 & 54.43 & 0.76 \\
\hline 26 & 46.77 & 36.60 & 82.56 & 68.51 & 1.35 \\
\hline 38 & 58.34 & 46.68 & 87.32 & 80.24 & 2.89 \\
\hline 53 & 69.87 & 57.02 & 92.34 & 87.39 & 4.47 \\
\hline 75 & 79.16 & 65.79 & 95.41 & & 7.30 \\
\hline 106 & 89.30 & 75.62 & 98.82 & & 11.02 \\
\hline 150 & 94.87 & 92.46 & 99.92 & & 16.47 \\
\hline 212 & 97.84 & 99.66 & 100.00 & & 24.17 \\
\hline 300 & & & & & 34.99 \\
\hline 425 & & & & & 48.55 \\
\hline 600 & & & & & 63.91 \\
\hline 850 & & & & & 79.79 \\
\hline
\end{tabular}

chalcopyrite (INDEX $=1.0$ ). The association of galena with siderite decreases from $28 \%$ to $22 \%$ as galena grain size increases to the $+75 \mu \mathrm{m}$ size interval. Galena's association with quartz shows the same trend. In contrast, the association of galena with sphalerite increases with galena grain size from $12 \%$ to a high of $33 \%$. There is such poor association between galena and muscovite (INDEX $=-.93$ ) that there appears to be a tendency for non-association between the two minerals. Sphalerite is associated with quartz (56\%), siderite $(21 \%)$ and galena (13\%). It is preferentially associated with siderite 


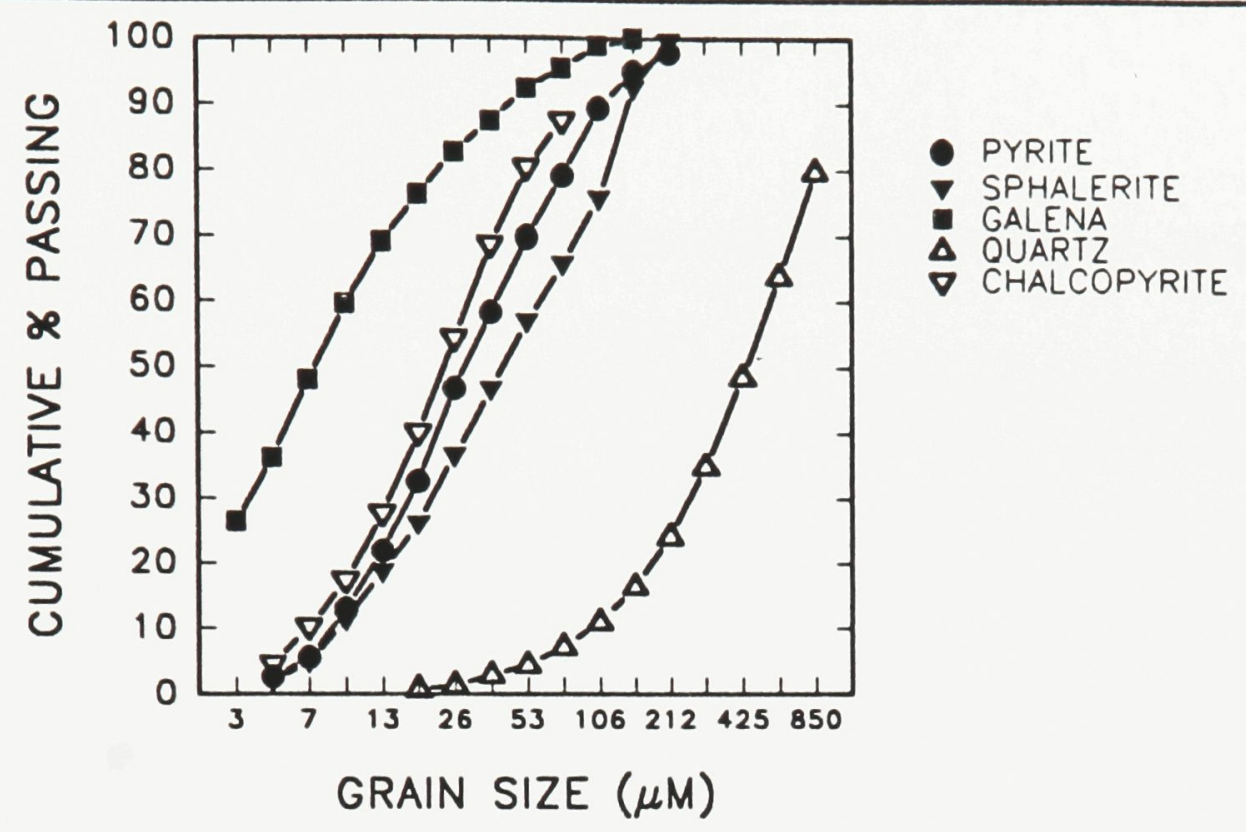

Figure 11 Grain size distributions of ore minerals in Faro 2BCD ore.

$($ INDEX $=.62)$ and chalcopyrite (INDEX $=3.0$ ). There is no obvious variation of the associations of sphalerite with size. Sphalerite also has a non-preferred association with pyrite (INDEX $=-.55)$ and muscovite (INDEX $=-.93$ ).

Optical examination shows that pyrite occurs in four textural types. It occurs primarily as fine to medium sized anhedral grains disseminated in the quartz matrix (Plate 3). When locally abundant the pyrite grains form clusters of fine anhedral grains. Less often pyrite occurs as closely crowded, euhedral to anhedral grains up to $500 \mu \mathrm{m}$ in diameter. Sphalerite, galena and chalcopyrite are often interstitial to the larger pyrite grains. Such a texture is typical of the $2 \mathrm{E}$ ore described next and indicates gradation between $2 \mathrm{BCD}$ and $2 \mathrm{E}$ ores. Banding is not often evident but in some sections pyrite grains appear to be aligned in hand specimen. Pyrite sometimes occurs in cloudy microcrystalline masses mixed with marcasite. Occasionally, pyrite appears as veinlets in 
TABLE 8

MINERAL ASSOCIATIONS OF GALENA AND SPHALERITE IN 2BCD ORE BY GRAIN SIZE (PERIMETERX)

galema

\begin{tabular}{|c|c|c|c|c|c|c|c|c|}
\hline $\begin{array}{c}\text { GAL GRAIN } \\
\text { SIZE } \\
(\mu N) \\
\end{array}$ & OT2 & SID & PY & $C P$ & BAR & PO & WUSC & SP \\
\hline+150 & 36 & 36 & 2 & 0 & 0 & 0 & 1 & 25 \\
\hline+106 & 56 & 29 & 4 & 0 & 0 & 1 & 2 & 8 \\
\hline+75 & 34 & 22 & 8 & 1 & 0 & 0 & 2 & 33 \\
\hline+53 & 44 & 22 & 1 & 2 & 0 & 0 & 1 & 30 \\
\hline+38 & 66 & 20 & 1 & 1 & 0 & 0 & 1 & 11 \\
\hline+26 & 59 & 21 & 2 & 4 & 0 & 0 & 0 & 14 \\
\hline+9 & 61 & 22 & 2 & 2 & 0 & 0 & 1 & 12 \\
\hline+1 & 56 & 28 & 2 & 1 & 0 & 0 & 1 & 12 \\
\hline ALL SIZES & 55 & 25 & 2 & 2 & 0 & 0 & 1 & 15 \\
\hline EXPECTED & 48 & 13 & 11 & 1 & 0 & 0 & 14 & 13 \\
\hline INDEX & .12 & .92 & -.82 & 1.0 & na & na & -.93 & .15 \\
\hline
\end{tabular}

SPHALERITE

\begin{tabular}{||r|r|r|r|r|r|r|r|r||}
\hline $\begin{array}{c}\text { SP GRAIN } \\
\text { SIZE }(\mu M)\end{array}$ & \multicolumn{1}{|c|}{ QTZ } & \multicolumn{1}{|c|}{ SID } & \multicolumn{1}{c|}{ PY } & \multicolumn{1}{c|}{ CP } & \multicolumn{1}{c|}{ BAR } & PO & MUSC & GAL \\
\hline+150 & 60 & 20 & 6 & 3 & 0 & 0 & 0 & 11 \\
\hline+106 & 53 & 20 & 5 & 3 & 0 & 0 & 0 & 19 \\
\hline+75 & 58 & 22 & 3 & 7 & 0 & 0 & 0 & 10 \\
\hline+53 & 57 & 19 & 5 & 2 & 0 & 0 & 1 & 16 \\
\hline+38 & 45 & 26 & 8 & 3 & 0 & 0 & 1 & 17 \\
\hline+26 & 59 & 15 & 4 & 6 & 0 & 0 & 1 & 15 \\
\hline+9 & 59 & 23 & 3 & 4 & 0 & 0 & 0 & 11 \\
\hline+1 & 0 & 0 & 0 & 0 & 0 & 0 & 0 & 0 \\
\hline ALL S1ZES & 56 & 21 & 5 & 4 & 0 & 0 & 1 & 13 \\
\hline EXPECTED & 49 & 13 & 11 & 1 & 0 & 0 & 14 & 12 \\
\hline INDEX & .14 & .62 & -.55 & 3.0 & $n a$ & $n$ & -.93 & .08 \\
\hline
\end{tabular}




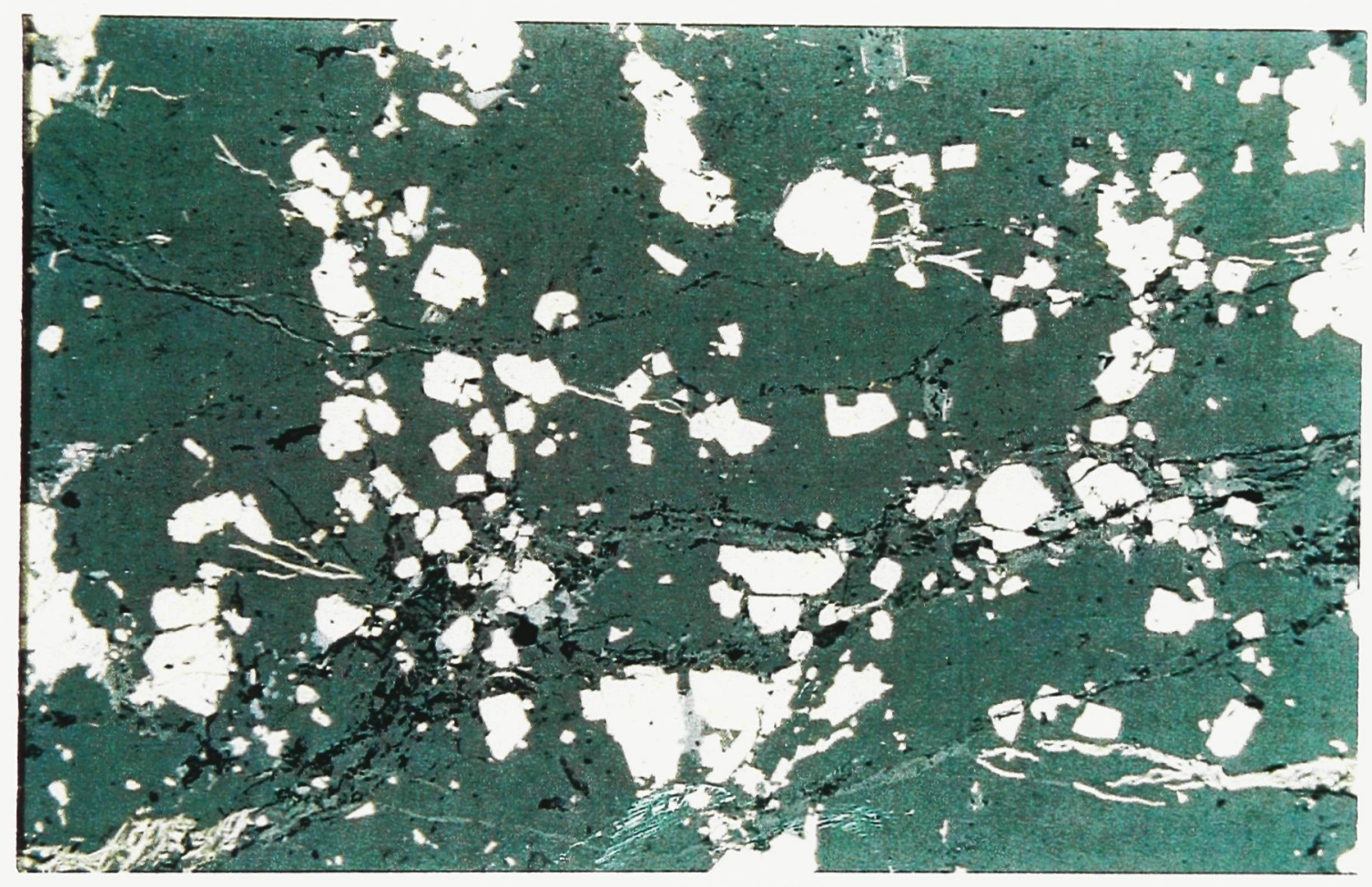

Scale: |---------1 $1 \mathrm{~mm}$

\section{Plate 3}

Photomicrograph of $2 \mathrm{BCD}$ ore showing disseminated grains and veinlets of pyrite in a quartz matrix. 
the quartz matrix.

Where present in significant amounts sphalerite occurs as irregular masses in the quartz matrix. Also it is found associated with galena as well as pyrite and chalcopyrite. The majority of sphalerite grains in all ore types contain minute blebs of chalcopyrite and, much less often, pyrrhotite. This so-called chalcopyrite disease is best developed in the $2 \mathrm{BCD}$ ore where it was detected by the perimeter association technique. In Table 8 a comparison of association of sphalerite with chalcopyrite (3.56\%) with the expected association $(0.48 \%)$ indicated preferred association with chalcopyrite. This is interpreted as numerical evidence for chalcopyrite dissemination in sphalerite.

Arsenopyrite is rare and occurs as euhedral to subhedral coarse grains associated with pyrite.

Common in all the ore types, marcasite occurs mainly as a fibrous, feathery mass (Plate 4). It also occurs as cryptocrystalline masses of grains intergrown with pyrite. Occasionally, these masses show a sooty colloform-like banding (Plate 5). Rarely, does marcasite occur as idiomorphic crystals up to $1 \mathrm{~mm}$ long.

Gangue minerals occur as a matrix of coarse grained quartz, crosscut by veins of siderite and muscovite. The muscovite veins are similar to those of the dark bands of the $2 \mathrm{~A}$ ore, indicating a gradational ore facies change between the $2 \mathrm{~A}$ and the $2 \mathrm{BCD}$ ore types. Siderite often contains clusters of minute grains of galena (Table 8). Siderite oftenforms thin rims on magnetite. Large grains of magnetite containing many small inclusions of pyrite are observed in several sections. 


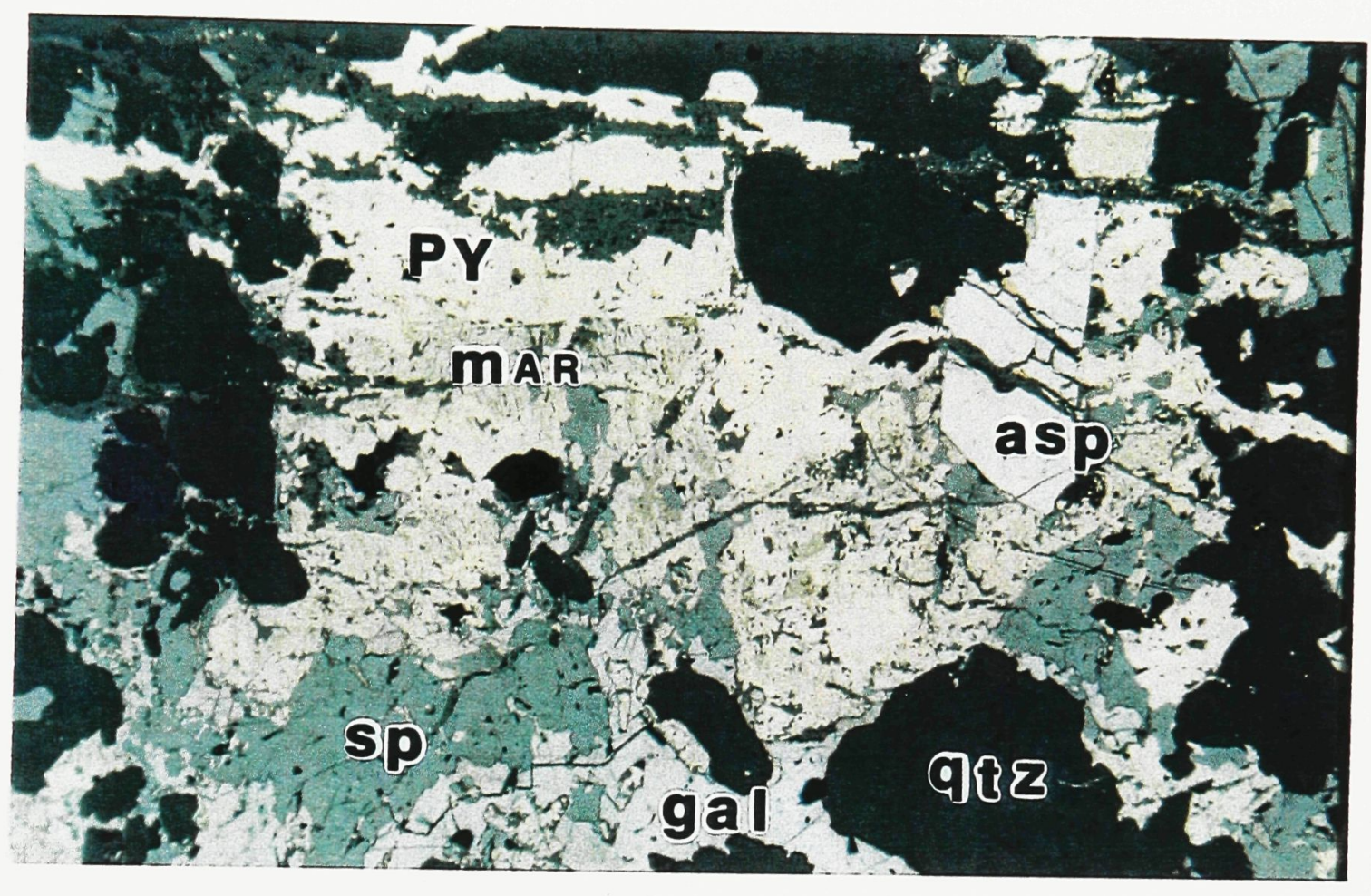

Scale: |--1 $1 \mathrm{~mm}$

\section{Plate 4}

Photomicrograph of $2 \mathrm{BCD}$ ore showing wispy masses of marcasite (mar) associated with pyrite (py) in a matrix of sphalerite (sp). Nearby are grains of galena (gal) and a single subhedral grain of arsenopyrite (asp). 


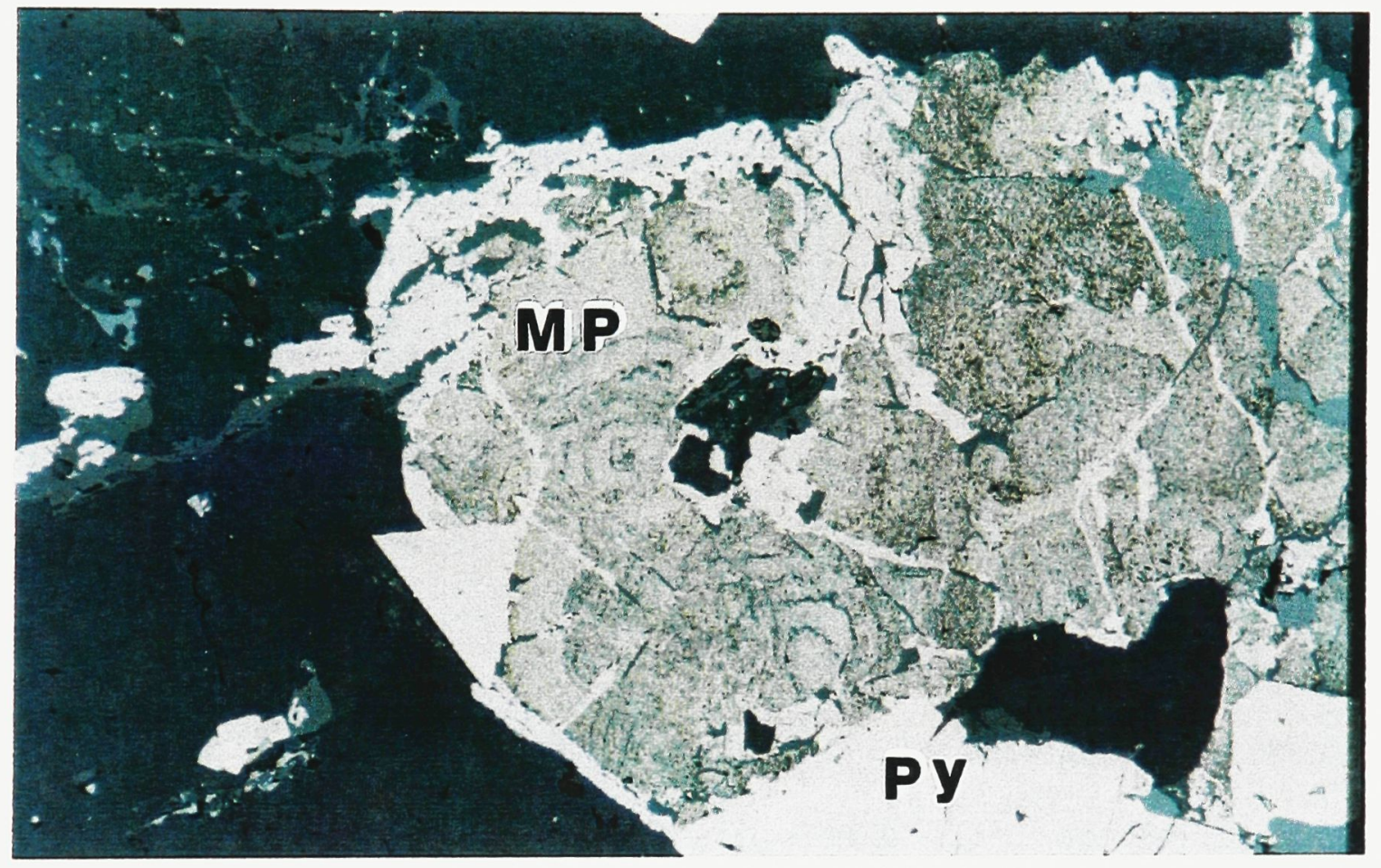

Scale:

$1 \mathrm{~mm}$

\section{Plate 5}

Photomicrograph of $2 \mathrm{BCD}$ ore showing banded cryptocrystalline masses $(\mathrm{mp})$ of marcasite and pyrite associated with pyrite (py). 


\section{E ORE}

The $2 \mathrm{E}$ ore type is the third member of the cycle and is the most important, comprising about $60 \%$ of the total orebody. Eighteen polished sections of this ore type were examined.

The chemical and modal analyses of twelve combined core samples of $2 \mathrm{E}$ ore are shown in Tables 3 and 4, respectively. Minerals identified in this ore type are, in order of descending abundance: pyrite, sphalerite, siderite, galena, quartz, marcasite, barite, and trace amounts of pyrrhotite, muscovite, chalcopyrite, kaolinite, tetrahedrite, gold-silver alloy, apatite, cassiterite, stannite, arsenopyrite, monazite, and native silver.

The grain size distributions of pyrite, sphalerite, galena, chalcopyrite, quartz and pyrrhotite are shown in Table 9 and plotted in Figure 12. The samples of 2E ore examined included the coarse variant, $2 \mathrm{~F}$, which is reflected in the very large pyrite grain size distribution. Quartz is next largest followed by sphalerite, galena, pyrrhotite and chalcopyrite. The quartz grain size distribution reflects the true size of the grains as clusters of quartz grains were not common in $2 \mathrm{E}$ ore. Galena and sphalerite grains are larger in $2 \mathrm{E}$ ore than in $2 \mathrm{~A}$ ore and galena grains are larger than those in $2 \mathrm{BCD}$ ore. However, there is still a significant portion of galena, $10 \%$, which is smaller than $3 \mu \mathrm{m}$.

The associations of sphalerite and galena as determined by the perimeter technique are shown in Table 10 . The data show that galena is closely associated with pyrite (56\%) and preferentially associated with sphalerite (INDEX $=.82)$. Galena has a non-preferred association with quartz (INDEX = -.68). The association of galena with quartz decreases uniformly from $15 \%$ at the finest size interval to $3 \%$ at the coarsest. This is interpreted 
TABLE 9

GRAIN SIZE DISTRIBUTIONS FOR FARO 2E ORE (CUMULATIVE \% PASSINO)

\begin{tabular}{|c|c|c|c|c|c|c|}
\hline $\begin{array}{c}\text { GRAN } \\
\text { SLZE } \\
(\mu M)\end{array}$ & PY & SP & GAL & $\mathrm{CP}$ & QTZ & PO \\
\hline 3.4 & 0.05 & 1.13 & 10.06 & 5 & 1.4 & 1.24 \\
\hline 4.7 & 0.09 & 2.68 & 13.22 & 18.44 & 2.39 & 2.27 \\
\hline 6.7 & 0.27 & 7.41 & 19.91 & 32.54 & 3.12 & 12.80 \\
\hline 9.4 & 0.71 & 15.03 & 27.75 & 73.19 & 11.55 & 38.15 \\
\hline 13 & 1.49 & 25.95 & 35.85 & 100.00 & 18.26 & 56.65 \\
\hline 19 & 3.05 & 37.28 & 43.72 & & 25.03 & 79.85 \\
\hline 26 & 5.60 & 44.93 & 52.12 & & 33.21 & 86.40 \\
\hline 38 & 9.97 & 58.06 & 63.01 & & 39.72 & 93.05 \\
\hline 53 & 15.89 & 66.13 & 75.34 & & 47.88 & 100.00 \\
\hline 75 & 23.80 & 74.77 & 85.53 & & 55.75 & \\
\hline 106 & 34.32 & 82.22 & 93.73 & & 64.65 & \\
\hline 150 & 46.55 & 88.84 & 98.32 & & 74.88 & \\
\hline 212 & 58.55 & 94.25 & 99.42 & & 85.42 & \\
\hline 300 & 68.45 & & & & & \\
\hline 425 & 78.55 & & & & & \\
\hline 600 & 87.50 & & & & & \\
\hline 850 & 92.42 & & & & & \\
\hline
\end{tabular}

as galena dissemination in quartz. In contrast the association of galena with sphalerite increases with galena grain size from $23 \%$ to a high of $45 \%$. Therefore coarse-grained galena is more closely associated with sphalerite than fine-grained galena. Sphalerite is closely associated with pyrite $(61 \%)$ and galena (26\%) but shows a stronger preferential association with galena (INDEX $=.73$ ). It also has a non-preferred association with quartz (INDEX $=-.52)$ and siderite (INDEX $=-.89$ ). The association of sphalerite with quartz 


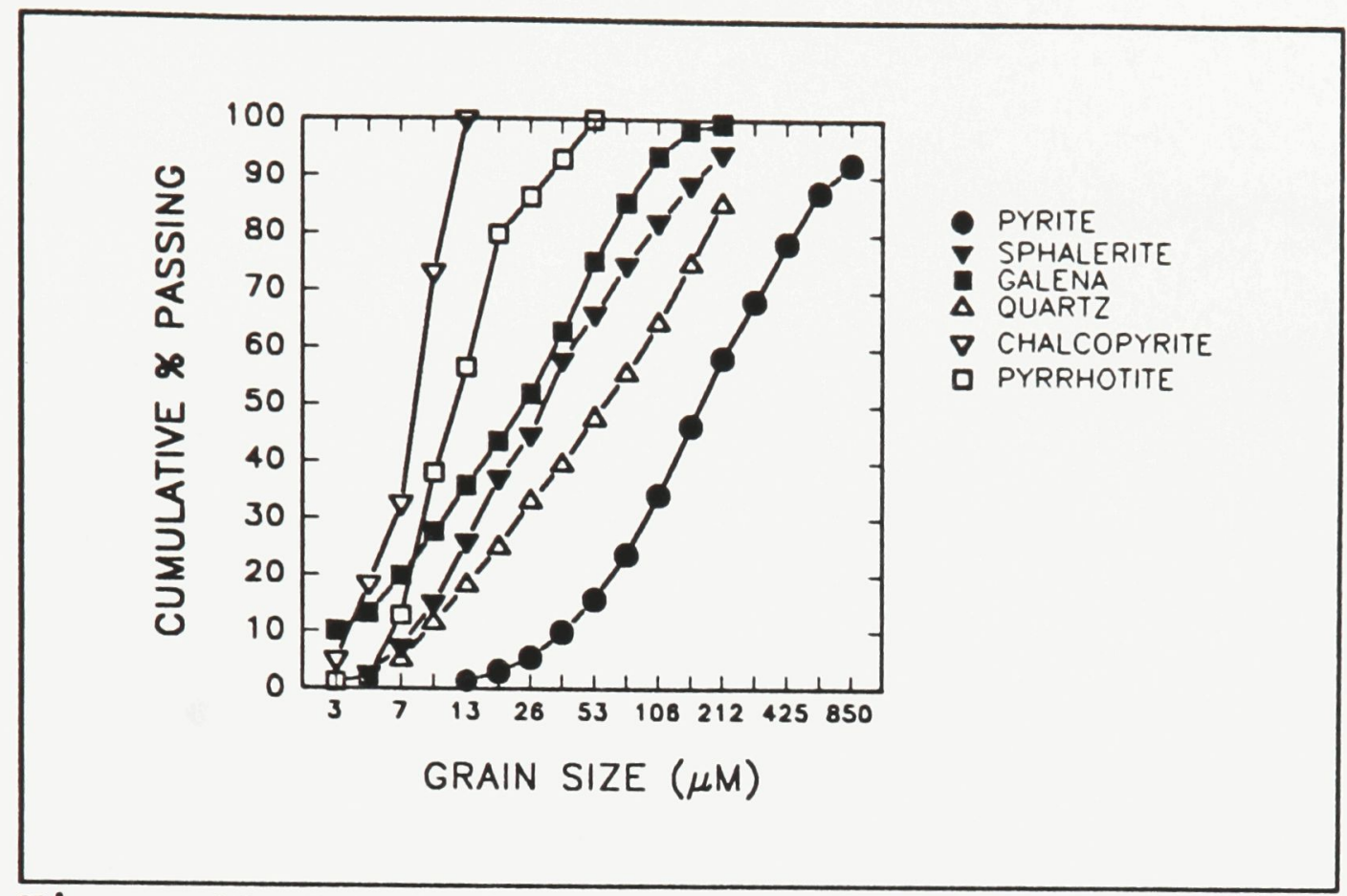

Figure 12 Grain size distributions of ore minerals in Faro 2E ore.

decreases from $34 \%$ at the finest size to $6 \%$ at the coarsest size. The association of sphalerite with pyrite increases from $51 \%$ to a high of $66 \%$ and with galena increases from $12 \%$ to $30 \%$ as its grain size increases. The associations of sphalerite with galena and of galena with sphalerite are plotted in Figure 13. The plot shows that coarser grains are more closely associated with each other than the finer grains. This texture is beneficial for mineral processing because the coarse grains will be more easily liberated from each other.

The $2 \mathrm{E}$ ore is characterized by the texture of the predominant pyrite. Typically, the pyrite occurs as large, closely spaced, rounded, anhedral grains with interstitial sphalerite and galena (Plate 6). Pyrrhotite occurs as small clusters interstitial to the pyrite. Deformation, brecciation and fracturing of pyrite is fairly common. Chalcopyrite, and less often galena, quartz and siderite, are often found as fracture fillings. A related texture of 
TABLE 10

MINERAL ASSOCIATIONS OF GALENA AND SPHALERITE IN $2 E$ ORE BY GRAIN SIZE (PERIMETERX)

GALENA

\begin{tabular}{|c|c|c|c|c|c|c|c|c|}
\hline $\begin{array}{c}\text { GAL GRAIN } \\
\text { SIZE } \\
(\mu M) \\
\end{array}$ & QTz & SIo & PY & CP & BAR & PO & MUSC & SP \\
\hline+150 & 3 & 2 & 52 & 0 & 0 & 0 & 0 & 42 \\
\hline+106 & 3 & 4 & 48 & 0 & 0 & 0 & 0 & 45 \\
\hline+75 & 6 & 4 & 54 & 0 & 0 & 0 & 1 & 35 \\
\hline+53 & 5 & 3 & 53 & 0 & 0 & 0 & 0 & 40 \\
\hline+38 & 6 & 3 & 48 & 0 & 0 & 0 & 0 & 42 \\
\hline+26 & 5 & 5 & 64 & 0 & 0 & 0 & 0 & 26 \\
\hline+9 & 11 & 4 & 64 & 0 & 0 & 0 & 1 & 21 \\
\hline+1 & 15 & 5 & 57 & 0 & 0 & 0 & 0 & 23 \\
\hline ALL SIZES & 8 & 4 & 56 & 0 & 0 & 0 & 0 & 31 \\
\hline EXPECTED & 25 & 9 & 49 & 0 & 0 & 0 & 0 & 17 \\
\hline INDEX & -.68 & -.56 & .14 & na & na & na & na & .82 \\
\hline
\end{tabular}

SPHALERITE

\begin{tabular}{|c|r|r|r|r|r|r|r|r||}
\hline $\begin{array}{c}\text { SP GRAIN } \\
\text { SIZE } \\
(\mu M)\end{array}$ & QTZ & \multicolumn{1}{|c|}{ SID } & \multicolumn{1}{c|}{ PY } & \multicolumn{1}{c|}{ CP } & BAR & PO & MUSC & GAL \\
\hline+150 & 6 & 1 & 62 & 0 & 0 & 0 & 1 & 30 \\
\hline+106 & 11 & 1 & 64 & 0 & 0 & 0 & 1 & 23 \\
\hline+75 & 16 & 1 & 66 & 0 & 0 & 0 & 1 & 17 \\
\hline+53 & 27 & 1 & 58 & 0 & 0 & 0 & 0 & 14 \\
\hline+38 & 27 & 1 & 54 & 0 & 0 & 0 & 0 & 17 \\
\hline+26 & 25 & 1 & 54 & 0 & 0 & 0 & 1 & 18 \\
\hline+9 & 34 & 1 & 51 & 0 & 0 & 0 & 1 & 12 \\
\hline+1 & 0 & 0 & 0 & 0 & 0 & 0 & 0 & 0 \\
\hline ALL SIZES & 12 & 1 & 61 & 0 & 0 & 0 & 1 & 26 \\
\hline EXPECTED & 25 & 9 & 49 & 0 & 0 & 0 & 0 & 15 \\
\hline INDEX & -.52 & -.89 & .24 & $n a$ & na & na & na & .73 \\
\hline
\end{tabular}




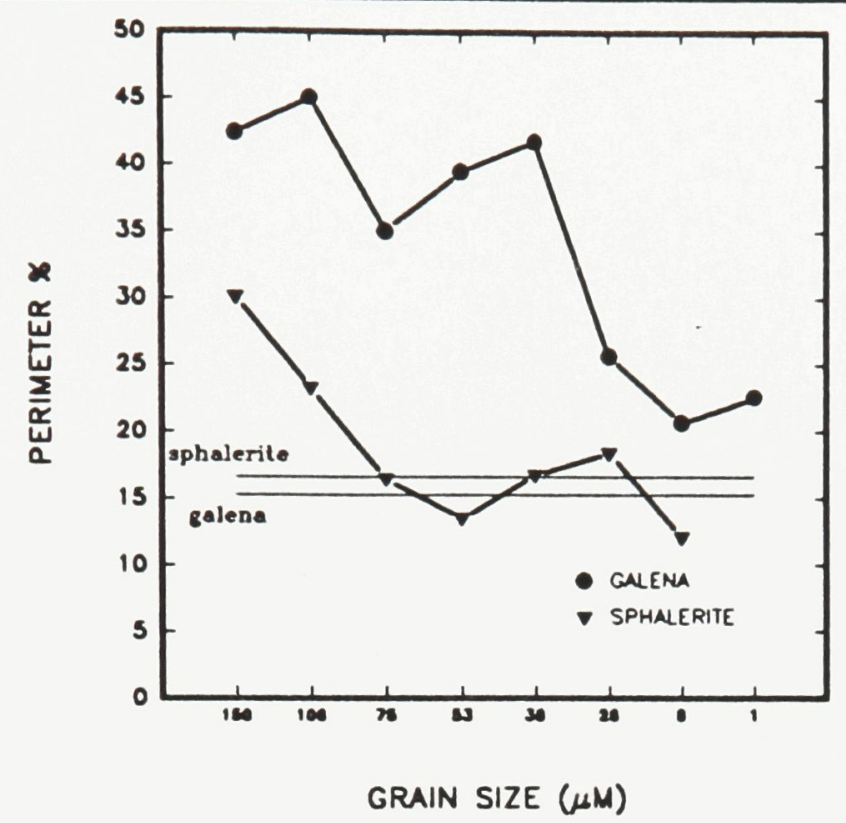

Figure 13 Associations of sphalerite and galena in $2 \mathrm{E}$ ore showing the increasing association with grain size. Flat lines show the expected associations.

this type, labelled $2 \mathrm{~F}$ or buckshot ore, displays a very coarse pyrite grain size (Plate 7).

In some samples diameters of up to $8 \mathrm{~mm}$ were observed. Because these rounded pyrite megacrysts are disseminated in a dark matrix they can easily be discerned with the naked eye and give the appearance of buckshot (Plate 8). Pyrite is most often inclusion-free but inclusions of sphalerite, galena and quartz may be found occasionally, particularly in the coarser grains. The inclusions were trapped within the pyrite grains as they grew during recrystallization. In hand specimen a vague banding is sometimes observed. The banding is defined by alternating layers of sphalerite with pyrite and/or barite.

\section{G ORE}

The second most important ore facies of the Faro deposit is the $2 \mathrm{G}$ ore, located at the top of the Anvil Cycle. This high grade massive sulphide ore is roughly defined as 




Scale: |--1 $1 \mathrm{~mm}$

\section{Plate 6}

Photomicrograph of $2 \mathrm{E}$ ore showing the typical arrangement of the ore minerals. Large closely-spaced fractured pyrite grains (py) have interstitial sphalerite (sp) and galena (gal). The black grains are quartz (qtz). Sometimes the fractures are infilled with sphalerite, galena and chalcopyrite. 


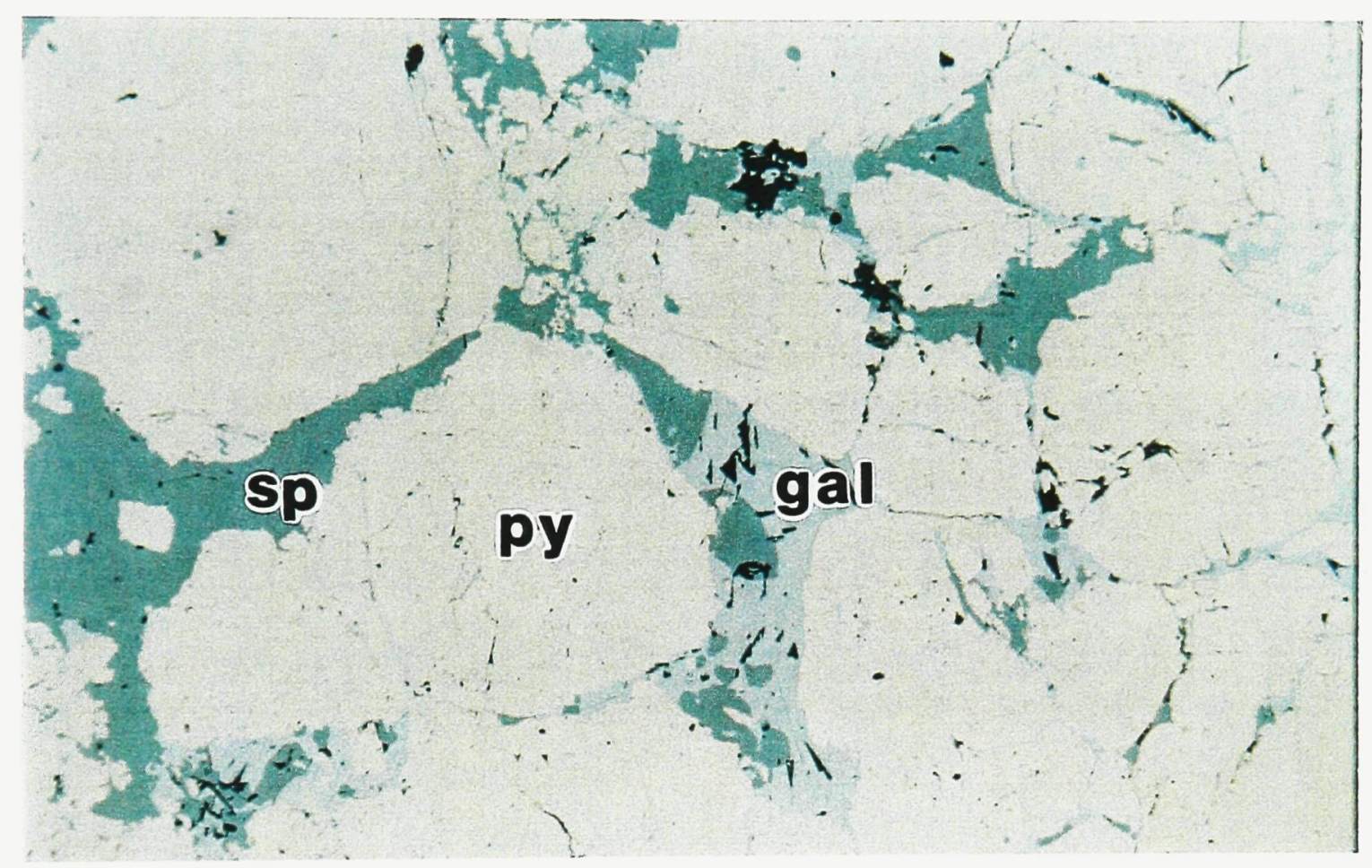

Scale: |--1 $1 \mathrm{~mm}$

\section{Plate 7}

Photomicrograph of a variant of $2 \mathrm{E}$ ore, called buckshot ore $(2 \mathrm{~F})$, showing rounded megacrysts of pyrite (py). sphalerite (sp) and galena (gal) are interstitial. 


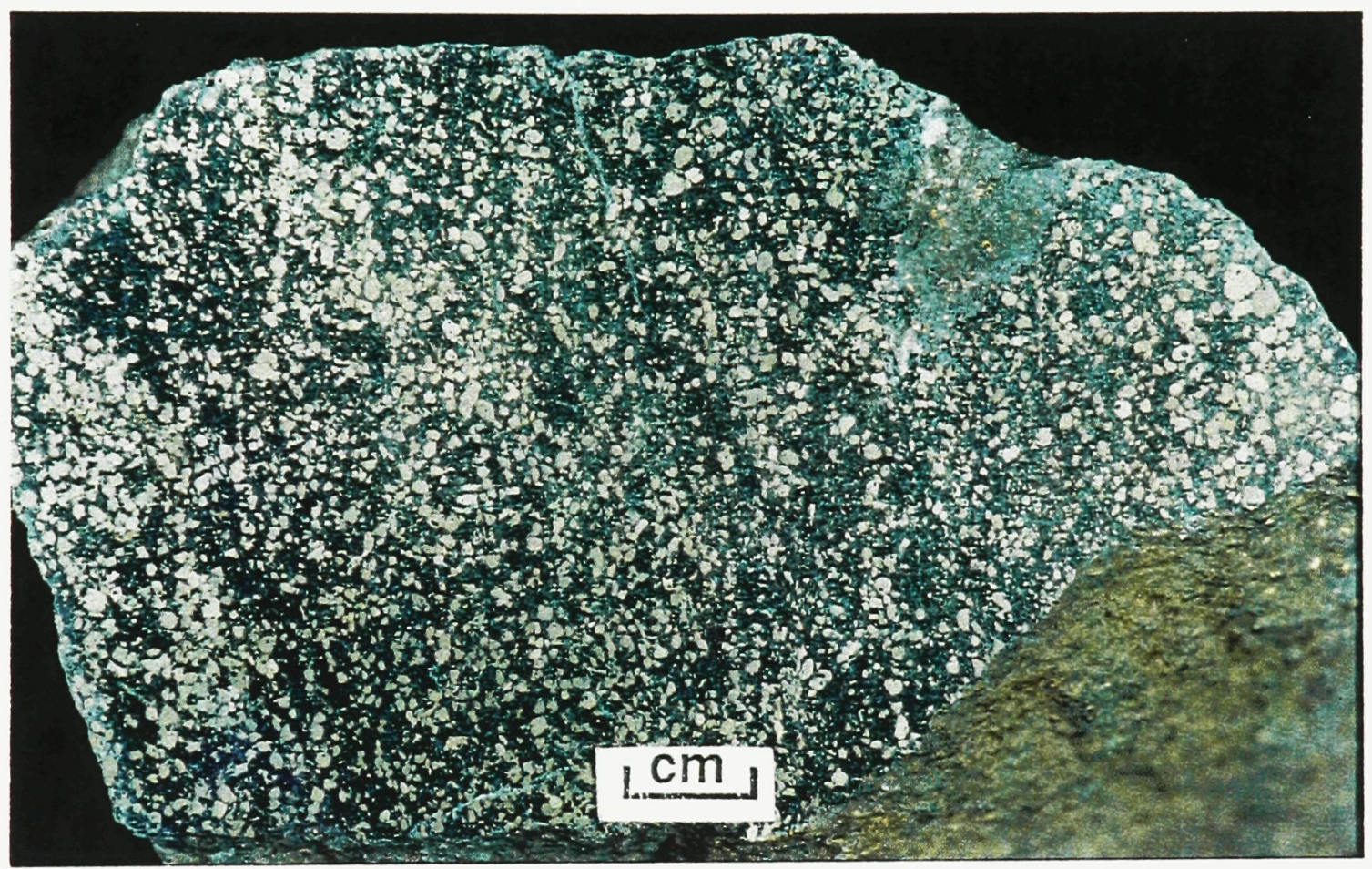

\section{Plate 8}

Photograph showing buckshot texture of $2 \mathrm{E}$ ore. Megacrysts of pyrite abound in a darker matrix of sphalerite, quartz and carbonate. 
having more than $10 \%$ barite and is gradational with the $2 \mathrm{E}$ type. Fourteen polished sections of this ore type were examined.

The chemical and modal analyses of six combined core samples of $2 \mathrm{G}$ ore are shown in Tables 3 and 4, respectively. Minerals identified in this ore type are, in order of descending abundance: pyrite, barite, sphalerite, siderite, galena, marcasite, pyrrhotite and trace amounts of quartz, chalcopyrite, celsian, muscovite, arsenopyrite and tetrahedrite.

The grain size distributions of pyrite, sphalerite, galena, chalcopyrite, pyrrhotite and barite are shown in Table 11 and plotted in Figure 14. Pyrite has almost the same grain size distribution as pyrite in $2 \mathrm{E}$ ore. Sphalerite and galena are both very coarse grained, in fact of all the ore types $2 \mathrm{G}$ ore contains the coarsest sphalerite and galena. Nevertheless, there is still a small but significant portion of galena which is finer than 3 $\mu \mathrm{m}$. Barite and sphalerite have similar grain size distributions. Pyrrhotite and chalcopyrite are very fine grained.

The associations of sphalerite and galena in $2 \mathrm{G}$ ore are shown in Table 12. Galena is most closely associated with barite $(31 \%)$, pyrite $(28 \%)$, sphalerite $(22 \%)$ and siderite (18\%). These associations are all close to the expected associations and therefore galena shows negligible preferential associations. Nevertheless there is a preference of coarsegrained galena to be associated with sphalerite over fine-grained galena.

Sphalerite is most closely associated with barite $(35 \%)$, pyrite $(31 \%)$, siderite $(14 \%)$ and quartz $(11 \%)$. It has a preference for quartz (INDEX $=1.2)$ and a nonpreferred association for galena (INDEX $=-.5$ ). The coarse-grained sphalerite is slightly 


\section{TABLE 11}

GRAIN SIZE DISTRIBUTIONS FOR FARO 20 ORE

(CUMULATIVE \% PASSING)

\begin{tabular}{|c|c|c|c|c|c|c|}
\hline $\begin{array}{l}\text { GRADN } \\
\text { SLZE } \\
(\mu M)\end{array}$ & PY & $\mathbf{S P}$ & OAL & $\mathrm{CP}$ & BAR & PO \\
\hline 3.4 & & 0.58 & 5.79 & 1.57 & 0.47 & 3.70 \\
\hline 4.7 & & 0.73 & 8.15 & 2.36 & 0.59 & 3.70 \\
\hline 6.7 & & 1.61 & 14.22 & 5.47 & 1.22 & 11.10 \\
\hline 9.4 & & 3.21 & 20.18 & 11.01 & 2.30 & 20.37 \\
\hline 13 & & 6.08 & 28.98 & 21.73 & 4.50 & 73.47 \\
\hline 19 & 1.13 & 10.71 & 35.00 & 33.70 & 7.83 & 85.20 \\
\hline 26 & 2.92 & 18.78 & 43.19 & 61.00 & 14.62 & 100.00 \\
\hline 38 & 6.11 & 28.86 & 50.61 & 80.20 & 25.83 & \\
\hline 53 & 10.18 & 43.06 & 59.70 & 88.99 & 42.83 & \\
\hline 75 & 17.40 & 56.69 & 67.80 & & 60.17 & \\
\hline 106 & 26.84 & 69.68 & 77.80 & & 77.70 & \\
\hline 150 & 40.59 & 82.92 & 85.49 & & 90.98 & \\
\hline 212 & 55.49 & 91.37 & 89.99 & & 97.29 & \\
\hline 300 & 67.77 & & & & & \\
\hline 425 & 77.82 & & & & & \\
\hline 600 & 85.30 & & & & & \\
\hline 850 & 91.48 & & & & & \\
\hline
\end{tabular}

more closely associated with galena than the fine-grained sphalerite.

Optical examination revealed that the texture of $2 \mathrm{G}$ ore is simple. It is defined by the rounded medium to coarse grained pyrite and barite. Coarse-grained sphalerite and galena form in the interstices of the pyrite and barite grains (See Plate 9). Pyrrhotite occurs as small clusters interstitial to the pyrite. Chalcopyrite occurs mainly as blebs in sphalerite. In those sections where pyrite is more abundant than barite the texture appears 


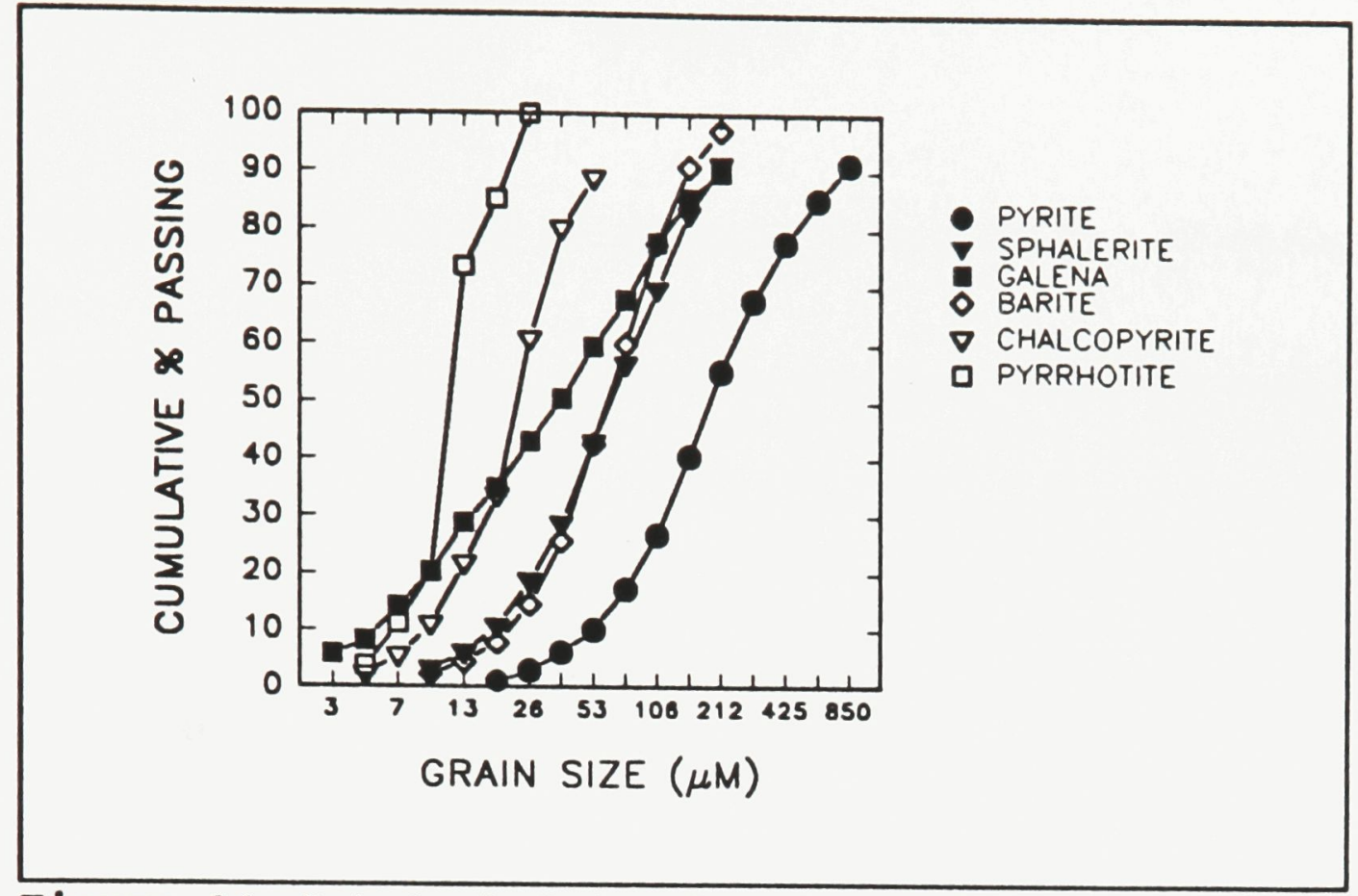

Figure 14 Grain size distributions of ore minerals in Faro $2 \mathrm{G}$ ore.

similar to that of typical $2 \mathrm{E}$ ore. Galena is frequently observed as minute grains disseminated in siderite.

\section{H ORE}

The massive pyrrhotitic sulphide ore type, $2 \mathrm{H}$, is not a facies of the Anvil Cycle but is a significant minor ore type in the Faro orebody and is gradational with the $2 \mathrm{E}$ ore. The chemical and modal analyses of only two combined core samples and a portion of one hand sample of $2 \mathrm{H}$ ore are shown in Tables 3 and 4 , respectively. It is felt that the lack of adequate samples is reflected in the unusually high sphalerite content. Seven polished sections of this ore type were examined. Minerals identified in this ore type are, in order of descending abundance: pyrrhotite, pyrite, siderite, sphalerite, galena, marcasite, and trace amounts of quartz, barite, chalcopyrite, arsenopyrite and muscovite. The grain 
TABLE 12

MINERAL ASSOCIATIONS OF GALENA NND SPHALERITE IN $2 G$ ORE BY GRAIN SIZE (PERIMETERX)

galema

\begin{tabular}{|c|c|c|c|c|c|c|c|c|}
\hline $\begin{array}{c}\text { GAL GRAIN } \\
\text { SIZE } \\
(\mu N A) \\
\end{array}$ & arz & SID & PY & $C P$ & BAR & PO & musc & SP \\
\hline+150 & 5 & 20 & 75 & 0 & 0 & 0 & 0 & 0 \\
\hline+106 & 1 & 12 & 37 & 0 & 16 & 0 & 0 & 34 \\
\hline+75 & 1 & 15 & 27 & 0 & 27 & 0 & 0 & 30 \\
\hline+53 & 0 & 9 & 33 & 0 & 32 & 0 & 0 & 26 \\
\hline+38 & 0 & 18 & 25 & 0 & 31 & 0 & 0 & 26 \\
\hline+26 & 1 & 11 & 22 & 0 & 33 & 0 & 0 & 33 \\
\hline+9 & 2 & 17 & 25 & 0 & 34 & 0 & 0 & 22 \\
\hline+1 & 1 & 24 & 27 & 0 & 31 & 0 & 0 & 17 \\
\hline ALL SIZES & 1 & 18 & 28 & 0 & 31 & 0 & 0 & 22 \\
\hline EXPECTED & 4 & 17 & 23 & 1 & 30 & 0 & 0 & 25 \\
\hline INDEX &.$- \pi 3$ & .06 & .22 & -1.0 & .03 & na & ne & -.12 \\
\hline
\end{tabular}

SPHALERITE

\begin{tabular}{|c|r|r|r|r|r|r|r|r||}
\hline $\begin{array}{c}\text { SP GRAIN } \\
\text { SIZE } \\
(\mu M)\end{array}$ & QTZ & \multicolumn{1}{|c|}{ SID } & \multicolumn{1}{c|}{ PY } & \multicolumn{1}{c|}{ CP } & \multicolumn{1}{c|}{ BAR } & PO & MUSC & GAL \\
\hline+150 & 9 & 13 & 28 & 0 & 38 & 0 & 0 & 12 \\
\hline+106 & 15 & 14 & 37 & 0 & 25 & 0 & 0 & 9 \\
\hline+75 & 13 & 12 & 32 & 0 & 34 & 0 & 0 & 9 \\
\hline+53 & 7 & 15 & 26 & 0 & 42 & 0 & 0 & 10 \\
\hline+38 & 13 & 19 & 23 & 0 & 36 & 0 & 0 & 9 \\
\hline+26 & 12 & 12 & 33 & 1 & 35 & 0 & 0 & 7 \\
\hline+9 & 12 & 18 & 36 & 0 & 27 & 0 & 0 & 7 \\
\hline+1 & 0 & 0 & 0 & 0 & 0 & 0 & 0 & 0 \\
\hline ALL SIZES & 11 & 14 & 31 & 0 & 35 & 0 & 0 & 9 \\
\hline EXPECTED & 5 & 18 & 26 & 1 & 32 & 0 & 0 & 18 \\
\hline INDEX & 1.2 & -.22 & .19 & -1.0 & .03 & $n$ & na & -.5 \\
\hline
\end{tabular}




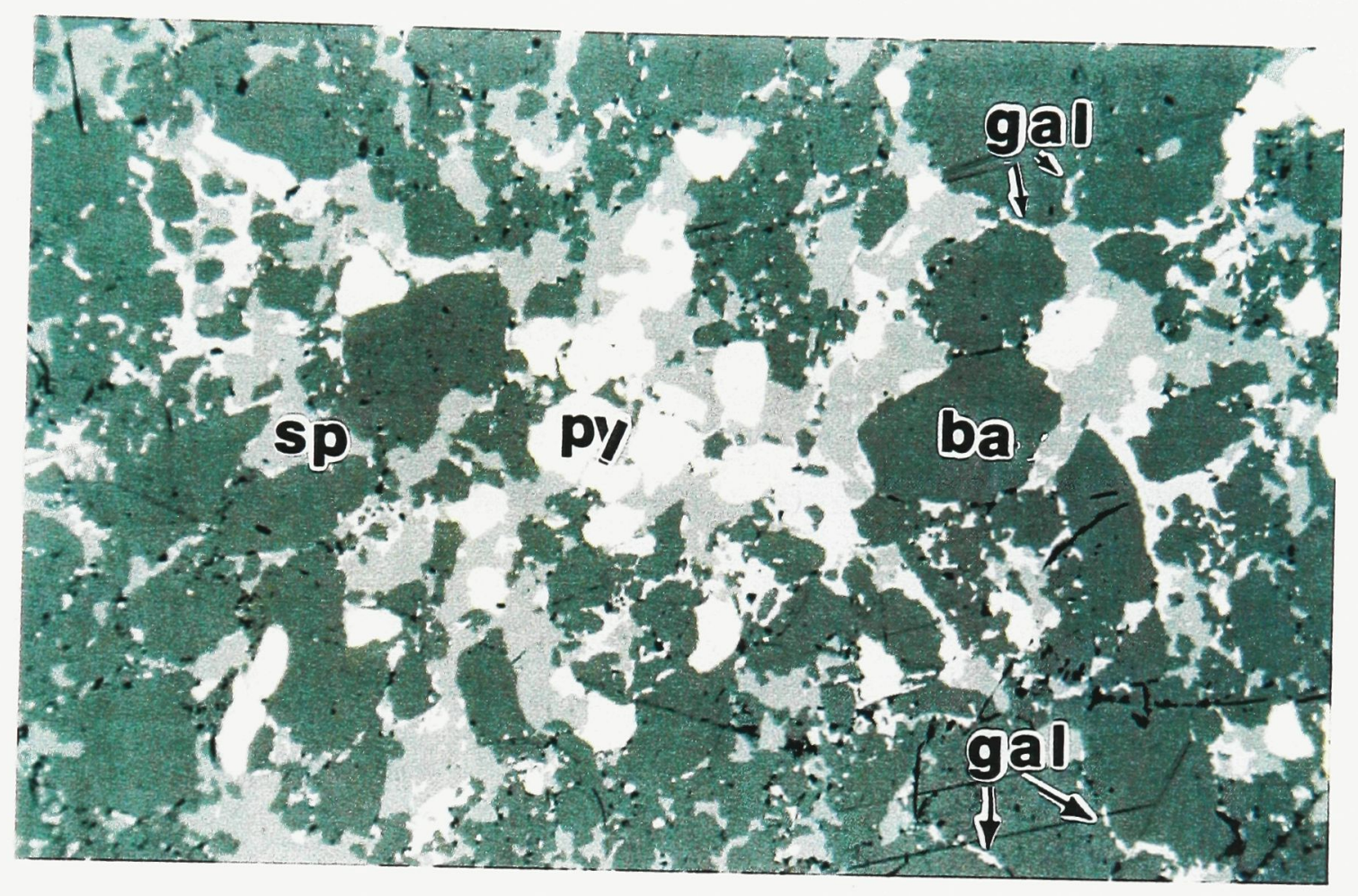

Scale: $1 \mathrm{~mm}$

Plate 9

Photomicrograph of $2 \mathrm{G}$ ore showing the typical arrangement of the ore minerals. Rounded anhedral closelycrowded barite grains (ba) and pyrite grains (py) dominate the texture. Interstitial to these are masses of sphalerite (sp) and small galena grains (gal). 
size distributions of pyrite, sphalerite, galena, chalcopyrite, and pyrrhotite are shown in Table 13 and Figure 15. Galena has a large portion, 20\%, less than $3 \mu \mathrm{m}$.

The associations of sphalerite and galena are shown in Table 14. Galena is mostly associated with pyrrhotite (40\%) and sphalerite $(29 \%)$ and has a slight preferential association with pyrrhotite (INDEX $=.21$ ). It also has a slight preferential association with quartz (INDEX = 1.0). The coarse-grained galena is more closely associated with sphalerite than the fine-grained galena. Also the fine-grained galena is more closely associated with pyrite than the coarse-grained galena.

Sphalerite is mostly associated with pyrrhotite (48\%), pyrite $(18 \%)$ and siderite $(16 \%)$. The coarse-grained sphalerite is more strongly associated with galena than the fine-grained sphalerite.

Typically, the ore consists of a pyrrhotitic matrix intimately associated with variable amounts of small grains of sphalerite and galena (Plate 10). The pyrrhotite grains are often aligned. Sphalerite is more abundant than galena in all the sections examined in which it often contains small blebs of pyrrhotite. Pyrite also often contains small pyrrhotite inclusions. Marcasite is fairly common replacing pyrrhotite. Chalcopyrite is present in trace amounts mostly as minor inclusions in sphalerite and sometimes pyrrhotite. Siderite and quartz are the important gangue minerals and occur as large masses and as veins cross-cutting the sulphide phases perpendicular to the alignment of the pyrrhotite. 
TABLE 13

GRAIN SLZE DISTRIBUTIONS FOR FARO 2H ORE

(CUMULATTVE \% PASSING)

\begin{tabular}{|c|r|r|r|r|r|}
\hline $\begin{array}{c}\text { GRAN } \\
\text { SIZE } \\
(\mu \mathrm{M})\end{array}$ & \multicolumn{1}{l|}{ PY } & \multicolumn{1}{l|}{ SP } & \multicolumn{1}{l|}{ GAL } & \multicolumn{1}{l|}{ CP } & \multicolumn{1}{l|}{ PO } \\
\hline 3.4 & 1.62 & 2.60 & 20.72 & 4.56 & 1.66 \\
\hline 4.7 & 2.41 & 3.85 & 27.33 & 8.60 & 2.50 \\
\hline 6.7 & 4.67 & 7.84 & 38.93 & 18.43 & 4.93 \\
\hline 9.4 & 10.67 & 16.94 & 50.34 & 38.70 & 10.27 \\
\hline 13 & 17.84 & 27.32 & 61.56 & 52.67 & 18.52 \\
\hline 19 & 25.87 & 38.73 & 69.75 & 66.14 & 28.83 \\
\hline 26 & 36.12 & 52.96 & 78.83 & 79.47 & 44.23 \\
\hline 38 & 48.45 & 67.23 & 86.27 & 87.96 & 59.93 \\
\hline 53 & 61.38 & 81.47 & 91.45 & 93.20 & 75.07 \\
\hline 75 & 74.04 & 91.11 & 94.64 & 100.00 & 85.25 \\
\hline 106 & 85.94 & 96.97 & 97.69 & & 91.79 \\
\hline 150 & 94.01 & 99.24 & 98.79 & & 96.28 \\
\hline 212 & 97.95 & 99.99 & 100.00 & & 98.80 \\
\hline
\end{tabular}

\section{MINERAL GRAIN SIZE DISTRIBUTIONS OF FARO ORES}

Table 15 shows a comparison of the $\mathrm{K}_{80}$ sizes of Faro ore types. The data show that the galena and sphalerite in $2 \mathrm{G}$ ore would be most easily liberated, followed by that of $2 \mathrm{E}, 2 \mathrm{BCD}$ and $2 \mathrm{H}$. Ore $2 \mathrm{~A}$ has the least favourable size distribution which is expected because that ore is generally treated as waste rock.

Pyrite is coarse-grained in all ore types, especially in the $2 \mathrm{E}$ and $2 \mathrm{G}$ ores in which it has an average $K_{80}$ of $425 \mu \mathrm{m}$. It is the coarsest-grained mineral in all the ore types except for ore $2 \mathrm{~A}$. 


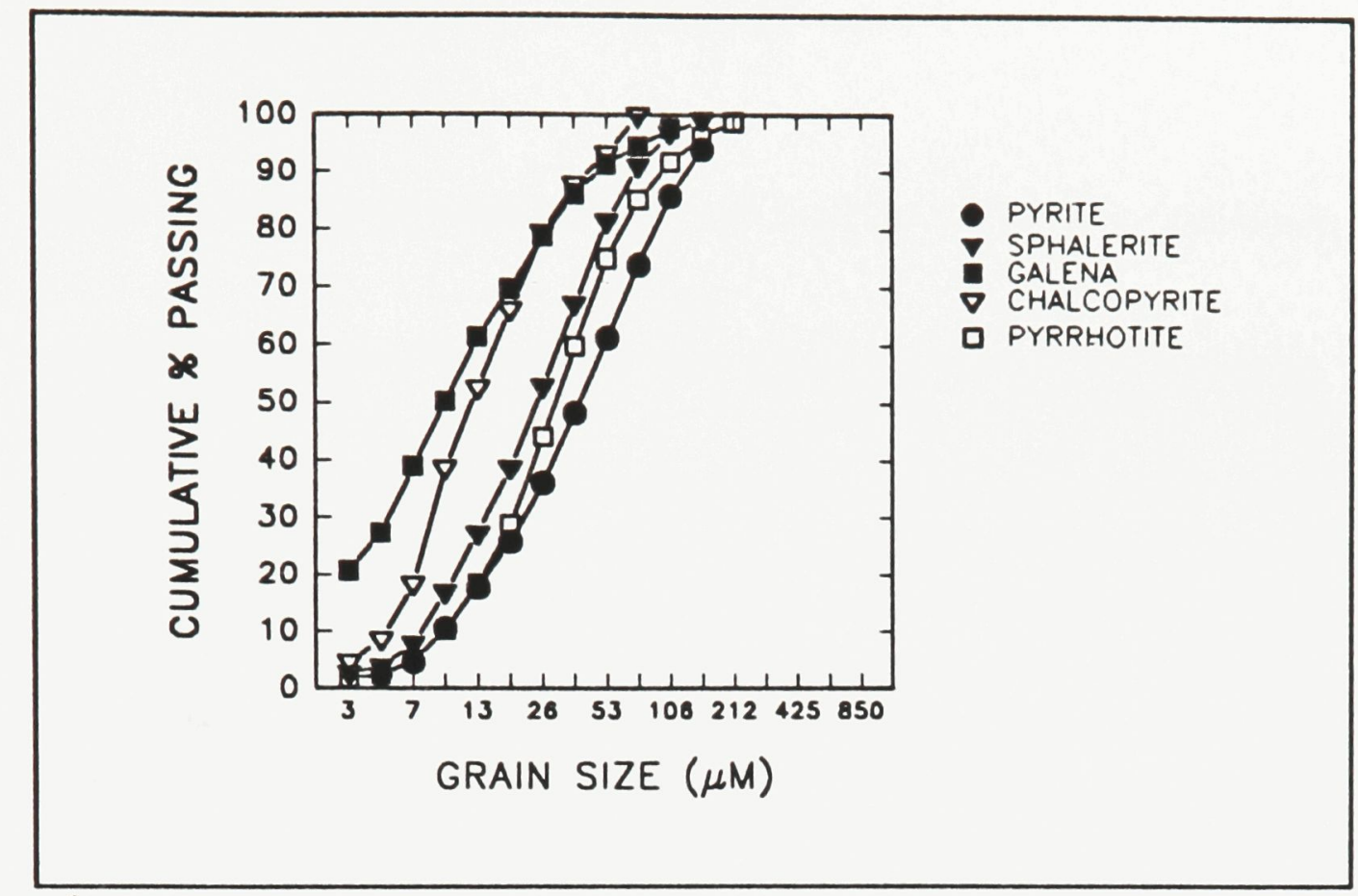

Figure 15 Grain size distributions of ore minerals in Faro 2H ore.

Overall galena has a wide size distribution, having a $\mathbf{K}_{80}$ ranging from 13 to 106 $\mu \mathrm{m}$ for the five ore types. The large proportion of fine-grained galena will present a problem for mineral processing. Most of the galena in the siliceous ore types, $2 \mathrm{~A}$ and $2 \mathrm{BCD}$, is extremely fine-grained. It is expected that most of the fine-grained galena is unrecoverable due to the unlikelihood of it being liberated in the concentrator. Sphalerite on the other hand has a better chance of being liberated due to its relatively coarse grain size, having an overall $\mathrm{K}_{80}$ of about $106 \mu \mathrm{m}$.

Tetrahedrite-tennantite is relatively fine-grained. Based on seventeen grains found, it has a size distribution visually estimated to range from 8 to over $150 \mu \mathrm{m}$ in diameter with a $\mathrm{K}_{80}$ of about $150 \mu \mathrm{m}$ (Table 16). Acanthite is a trace mineral in the Faro ore and only a few small grains, (all about $5 \mu \mathrm{m}$ in diameter) were found in the core samples. No unbroken grains of gold-silver alloy were found in any of the samples. It has been 
TABLE 14

MINERAL ASSOCIATIONS OF GALENA NND SPHALERITE IN 2H ORE BY GRAIN SIZE (PERIMETERX) gALEMA

\begin{tabular}{|c|c|c|c|c|c|c|c|c|}
\hline $\begin{array}{c}\text { GAL GRAIN } \\
\text { SIZE } \\
(\mu M) \\
\end{array}$ & OTz & SID & PY & CP & BAR & PO & Musc & SP \\
\hline+150 & 24 & 71 & 5 & 0 & 0 & 0 & 0 & 0 \\
\hline+106 & 8 & 10 & 6 & 0 & 0 & 42 & 0 & 34 \\
\hline+75 & 3 & 12 & 4 & 1 & 0 & 39 & 0 & 41 \\
\hline+53 & 13 & 8 & 4 & 0 & 0 & 44 & 0 & 30 \\
\hline+38 & 10 & 8 & 4 & 1 & 0 & 40 & 0 & 37 \\
\hline+26 & 16 & 7 & 7 & 0 & 0 & 39 & 0 & 31 \\
\hline+9 & 15 & 9 & 9 & 0 & 0 & 40 & 0 & 27 \\
\hline+1 & 10 & 10 & 11 & 0 & 0 & 41 & 0 & 28 \\
\hline ALL SIZES & 12 & 10 & 9 & 0 & 0 & 40 & 0 & 29 \\
\hline EXPECTED & 6 & 18 & 15 & 0 & 0 & 33 & 0 & 28 \\
\hline INDEX & 1.0 & -.44 & -.40 & na & na & .21 & na & .04 \\
\hline
\end{tabular}

SPHALERITE

\begin{tabular}{|c|c|c|c|c|c|c|c|c|}
\hline $\begin{array}{l}\text { SP GRAIN } \\
\text { SIZE } \\
(\mu M)\end{array}$ & QTz & SID & PY & CP & BAR & PO & MUSC & GAL \\
\hline+150 & 5 & 19 & 12 & 0 & 0 & 48 & 0 & 16 \\
\hline+106 & 4 & 20 & 18 & 0 & 0 & 46 & 0 & 12 \\
\hline+75 & 6 & 17 & 16 & 1 & 0 & 44 & 0 & 16 \\
\hline+53 & 7 & 17 & 16 & 1 & 0 & 48 & 0 & 11 \\
\hline+38 & 8 & 13 & 21 & 0 & 0 & 47 & 0 & 11 \\
\hline+26 & 7 & 15 & 20 & 0 & 0 & 49 & 0 & 9 \\
\hline+9 & 7 & 14 & 22 & 0 & 0 & 47 & 0 & 10 \\
\hline+1 & 0 & 0 & 0 & 0 & 0 & 0 & 0 & 0 \\
\hline ALL SIZES & 6 & 16 & 18 & 0 & 0 & 48 & 0 & 12 \\
\hline EXPECTED & 7 & 22 & 18 & 0 & 0 & 39 & 0 & 13 \\
\hline INDEX & -.14 & -.27 & 0 & na & na & .23 & na & -.08 \\
\hline
\end{tabular}




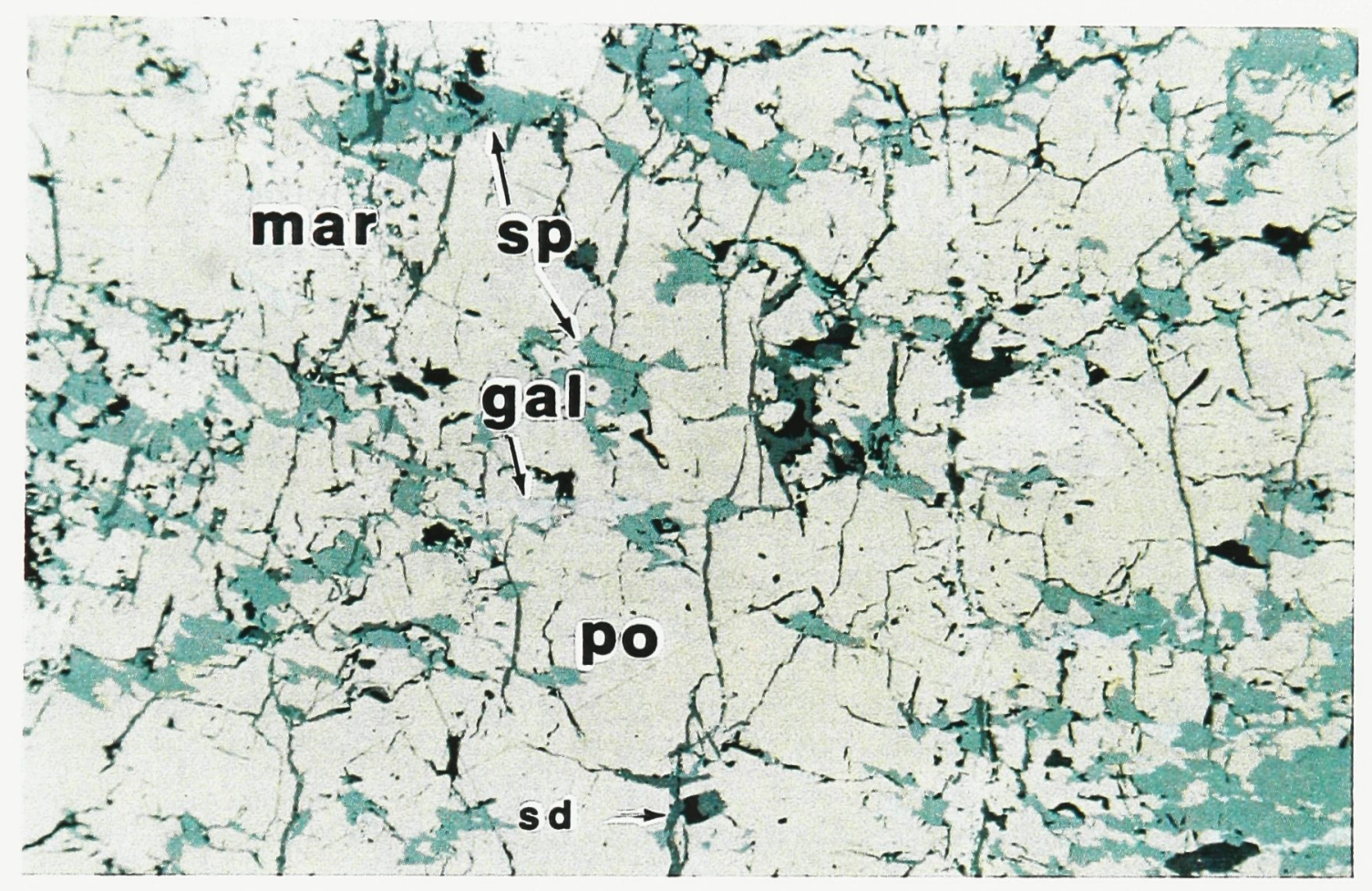

Scale: $1 \mathrm{~mm}$

\section{Plate 10}

Photomicrograph of $2 \mathrm{H}$ ore showing the typical arrangement of the ore minerals. Masses of pyrrhotite (po) and sphalerite (sp) form the ore matrix. Galena (gal) is common. Marcasite (mar) is found as an alteration product of pyrrhotite. Veins of siderite (sid) cut across the pyrrhotite matrix. 
TABLE 15

SLZE DISTRIBUTIONS OF ORE MINERALS IN FARO ORE TYPES ( $\mu \mathrm{M}, 80 \%$ PASSING)

\begin{tabular}{|l|c|c|c|c|c|}
\hline & $2 \mathrm{~A}$ & $2 \mathrm{BCD}$ & $2 \mathrm{E}$ & $2 \mathrm{O}$ & $2 \mathrm{H}$ \\
\hline Galen & 13 & 26 & 53 & 106 & 26 \\
\hline Sphalerite & 53 & 106 & 106 & 150 & 53 \\
\hline Pyrite & 212 & 75 & 425 & 425 & 106 \\
\hline
\end{tabular}

observed only in concentrator products in which it occurs as coarse free grains. Native silver is very rare. Only one grain has been observed, having a diameter of about $5 \mu \mathrm{m}$.

TABLE 16

SIZE DISTRIBUTION OF TETRAHEDRITE-TENNANTTTE GRAINS IN FARO ORE

\begin{tabular}{|l|c|c|}
\hline $\begin{array}{c}\text { Size Interval } \\
(\mu \mathrm{M})\end{array}$ & Frequency & WT\% \\
\hline+150 & 1 & 40 \\
\hline$-150+75$ & 3 & 43 \\
\hline$-75+38$ & 2 & 13 \\
\hline$-38+19$ & 3 & 2 \\
\hline-19 & 8 & 2 \\
\hline
\end{tabular}




\section{MINERAL ASSOCIATIONS OF FARO ORES}

The association data show that for the major ore type, $2 \mathrm{E}$, galena and sphalerite are preferentially associated with each other. This strong association is detrimental to processing because any lack of liberation of particles consisting of such mineral pairs will not only tend to reduce grade by dilution but also will reduce recovery of both minerals in their respective concentrates. Fortunately, in terms of liberation, the coarse-grained sphalerite and galena tend to be associated more closely than their fine-grained counterparts. Galena and sphalerite are associated with quartz in quartzose $2 A$ and $2 B C D$, with pyrite in pyritic $2 \mathrm{E}$ and barite in baritic $2 \mathrm{G}$. The strong association of galena with quartz in $2 \mathrm{~A}$ and $2 \mathrm{BCD}$ coupled with its fineness indicates difficulty in processing because quartz is such a hard mineral to grind. Similarly, sphalerite demonstrates the same tendency in quartzose ores although not as strong. In $2 \mathrm{E}$ ore, fine-grained galena is more closely associated with pyrite than coarse-grained galena is, which instead, prefers sphalerite. There is a very low association of both sphalerite and galena with muscovite.

Tetrahedrite-tennantite was found mostly in samples of the concentrator products in which it is mainly associated with galena and chalcopyrite but has also been observed associated with sphalerite, barite, siderite and pyrite. All the acanthite grains found are associated with galena. Its absence in the concentrator products may be due to the fact that it has been leached by cyanide used in the processing in which it is very soluble. The effects of cyanide which is used as a flotation depressant for pyrite and copper-activated sphalerite, will be discussed later in the chapter on the metallurgical characteristics of Faro ore. 
SUMMARY

Overall it is expected that $2 \mathrm{E}, 2 \mathrm{G}$ and $2 \mathrm{H}$ ores will be easy to process whereas 2BCD and $2 \mathrm{~A}$ will be more difficult. It is expected that pyrite will liberate at a relatively coarse grind in all ore types. Because significant quantities of sphalerite and galena are very fine-grained it is expected that sphalerite and galena recoveries will not be good. 


\section{CHAPTER 5}

\section{METALLURGICAL CHARACTERISTICS OF FARO ORE}

\section{INTRODUCTION}

The ore particles in the concentrator streams are characterized by assays, mineral quantities, particle sieve sizes, mineral grain sizes, mineral liberation and mineral associations. The arrangement of the process streams of the grinding circuit and the lead and zinc flotation circuits are shown in Figures 16, 17 and 18, respectively. Operating parameters of grinding circuits are given in Appendix 7. Ore mineral behaviour is determined by calculating the steady state flowrates and distributions in each stream by means of a materials balance technique. Lastly, concentrator data are combined with, and compared with, data acquired from unbroken ore to give a complete picture of the influence of mineralogy on the metallurgical characteristics of Faro ore.

\section{RESULTS AND DISCUSSION}

Grain Size Distribution of Ore Minerals in Unbroken Concentrator Feed

The ore fed to the Faro concentrator was a blend of $2 \mathrm{E}$ and $2 \mathrm{G}$ ores with a small component of $2 \mathrm{BCD}$ ore. The weighted grain size distributions of galena, sphalerite and pyrite in five selected unbroken ore samples of the rod mill feed were measured by image analysis and combined with those of $2 \mathrm{E}$ and $2 \mathrm{G}$ ores. The combined data are shown in Table 17 and plotted in Figure 19. Due to the scarcity of tetrahedrite, acanthite, silver and gold-silver alloy grains in the concentrator feed samples their grain size distributions are 


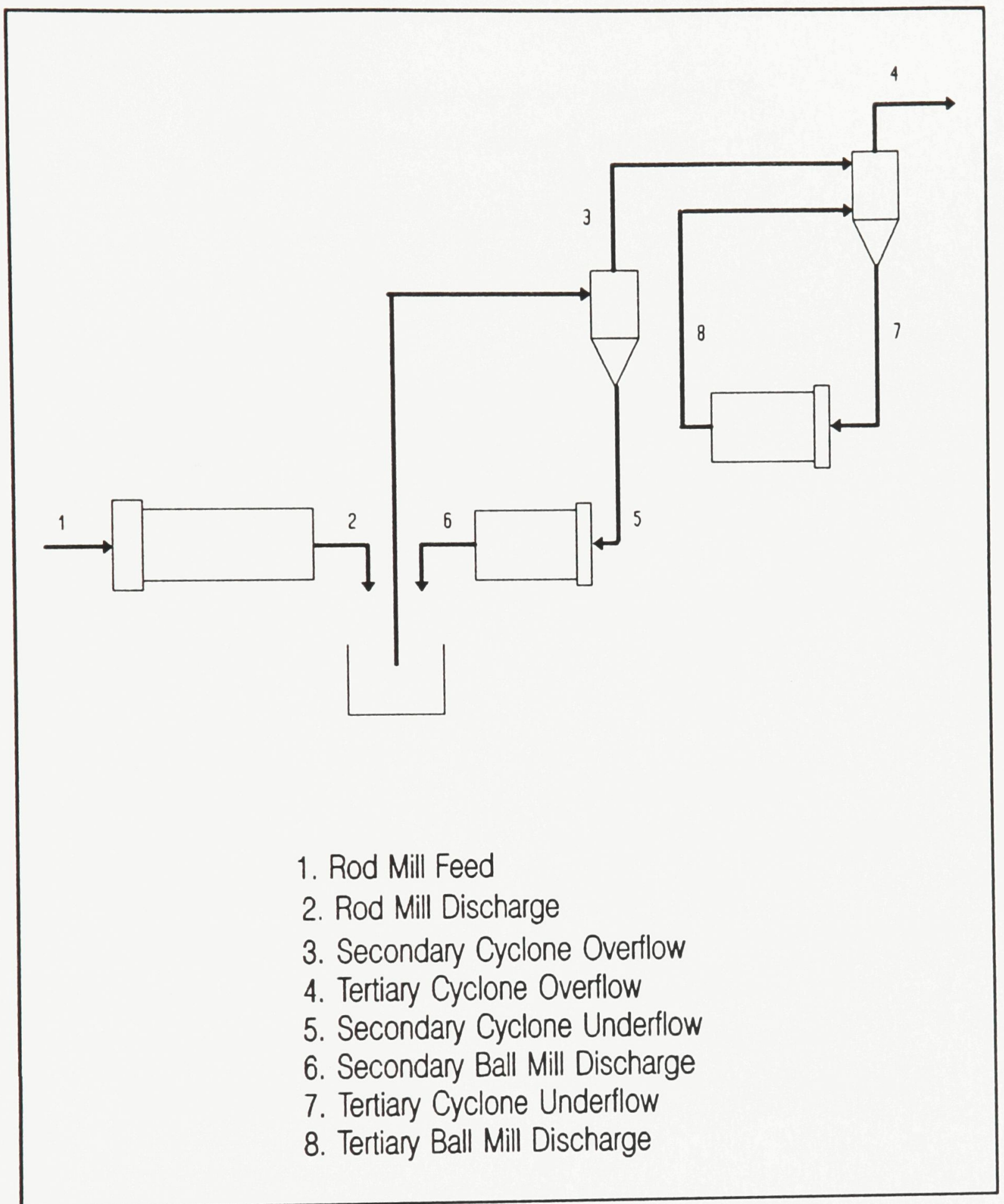

Figure 16 Flowsheet of Faro and Vangorda main grinding circuit. 


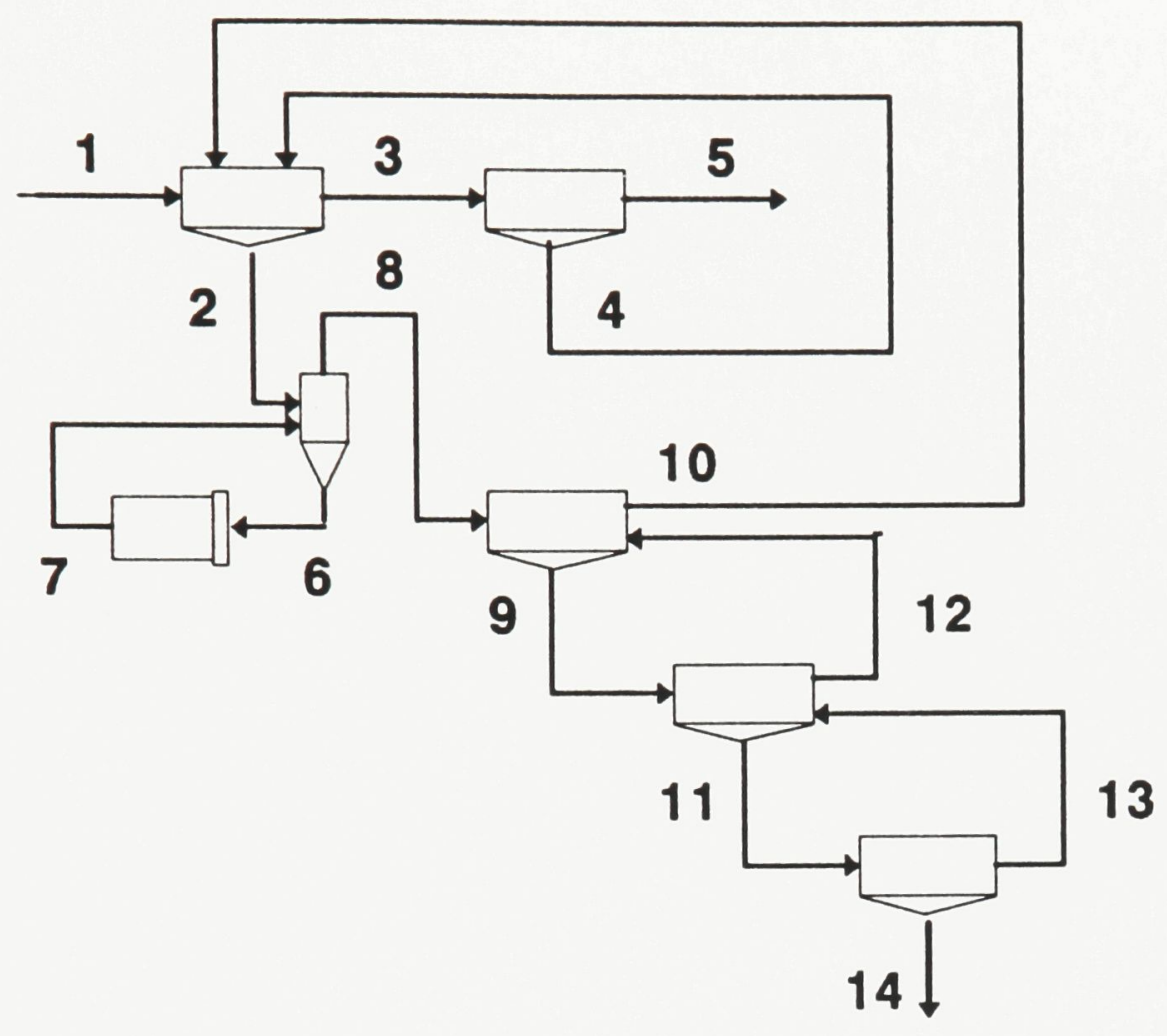

1. Rougher Feed

2. Rougher Concentrate

3. Rougher Tail

4. Scavenger Concentrate

5. Scavenger Tail

6. Cyclone Underflow

7. Regrind Mill Discharge
8. Cyclone Overflow

9. First Cleaner Concentrate

10. First Cleaner Tail

11. Second Cleaner Concentrate

12. Second Cleaner Tail

13. Third Cleaner Tail

14. Third Cleaner Concentrate

Figure 17 Faro lead flotation circuit. 


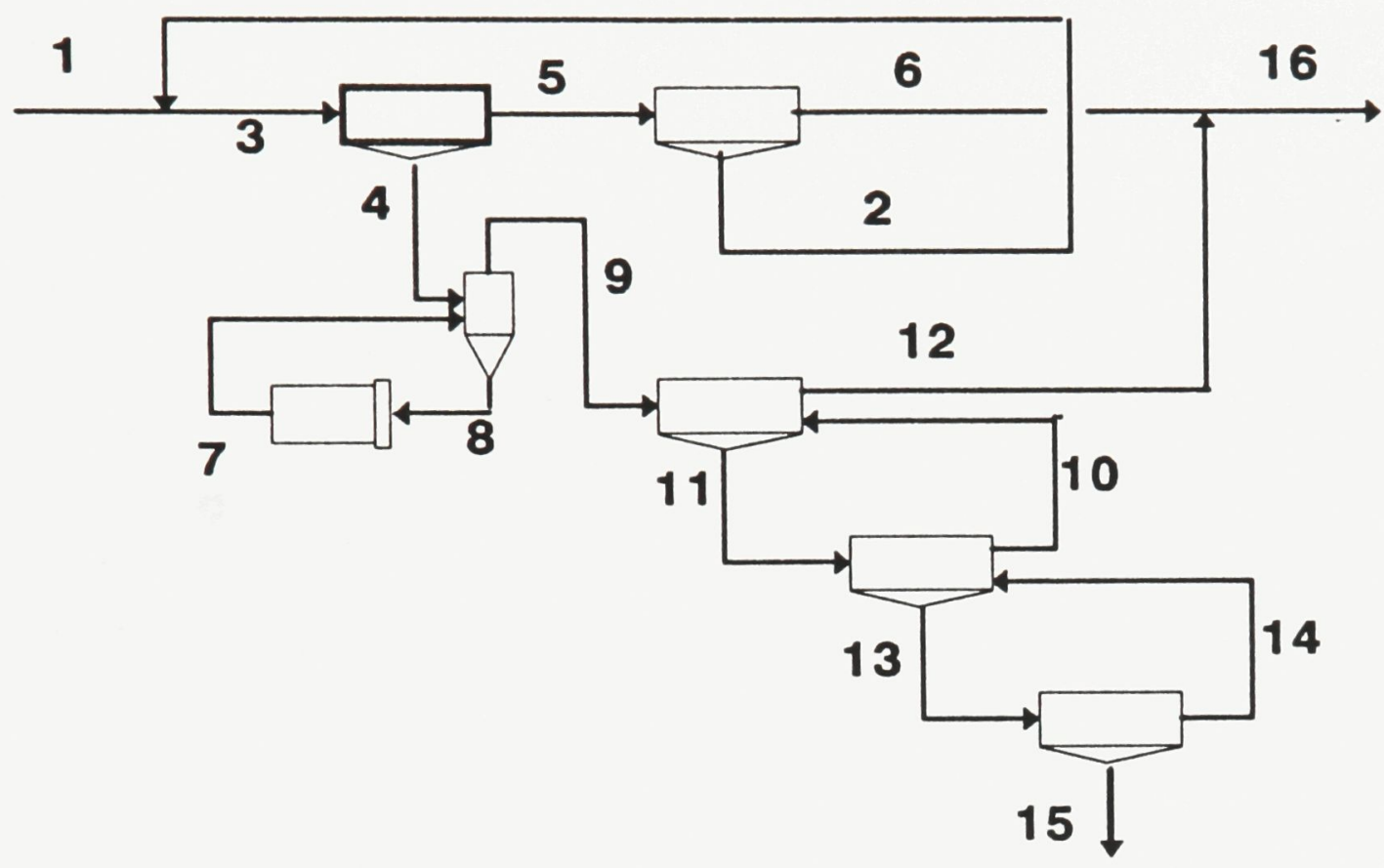

1. Lead Scavenger Tail

2. Scavenger Concentrate

3. Rougher Feed

4. Rougher Concentrate

5. Rougher Tail

6. Scavenger Tail

7. Regrind Discharge

8. Cyclone Underflow
9. Cyclone Overflow

10. Second Cleaner Tail

11. First Cleaner Concentrate

12. First Cleaner Tail

13. Second Cleaner Concentrate

14. Third Cleaner Tail

15. Third Cleaner Concentrate

16. Final Tail

Figure 18 Faro zinc flotation circuit. 
TABLE 17

GRAIN SIZE DISTRIBUTIONS OF FARO CONCENTRATOR FEED (CUMULATIVE \% PASSING)

\begin{tabular}{|c|c|c|c|c|c|c|c|c|}
\hline $\begin{array}{c}\text { GRAIN } \\
\text { SIZE } \\
(\mu \mathrm{M})\end{array}$ & PY & SP & GAL & BAR & QTZ & SID & CP & PO \\
\hline 3.4 & 0.10 & 0.33 & 2.86 & 0.47 & 0.92 & 0.00 & 3.51 & 2.47 \\
\hline 4.7 & 0.77 & 1.60 & 8.30 & 0.59 & 1.50 & 0.00 & 10.37 & 2.99 \\
\hline 6.7 & 0.87 & 2.01 & 10.40 & 1.22 & 3.38 & 0.09 & 18.66 & 11.95 \\
\hline 9.4 & 2.19 & 4.10 & 18.49 & 2.30 & 7.62 & 0.78 & 39.21 & 29.26 \\
\hline 13 & 3.70 & 7.05 & 26.89 & 4.50 & 12.18 & 2.11 & 56.69 & 65.06 \\
\hline 19 & 5.85 & 10.75 & 35.09 & 7.83 & 16.77 & 4.30 & 64.37 & 82.53 \\
\hline 26 & 9.44 & 18.62 & 47.11 & 14.62 & 22.36 & 8.41 & 78.10 & 93.20 \\
\hline 38 & 14.64 & 30.08 & 60.28 & 25.83 & 27.17 & 17.08 & 88.12 & 96.53 \\
\hline 53 & 21.12 & 42.88 & 72.25 & 42.83 & 33.08 & 33.48 & 93.07 & 100.00 \\
\hline 75 & 30.00 & 57.45 & 83.15 & 60.17 & 39.20 & 49.16 & & \\
\hline 106 & 41.35 & 70.52 & 90.39 & 77.70 & 46.31 & 63.20 & & \\
\hline 150 & 53.37 & 81.72 & 95.37 & 90.98 & 54.86 & 74.37 & & \\
\hline 212 & 66.65 & 89.78 & 98.92 & 97.29 & 64.35 & 84.19 & & \\
\hline 300 & 74.49 & & & & & & & \\
\hline 425 & 82.55 & & & & & & & \\
\hline 600 & 89.12 & & & & & & & \\
\hline 850 & 93.56 & & & & & & & \\
\hline$K_{\infty 0}$ & 425 & 150 & 75 & 106 & & 212 & 26 & 19 \\
\hline$K_{30}$ & 75 & 38 & 13 & 38 & 38 & 53 & 9.4 & 9.4 \\
\hline
\end{tabular}

taken as those already reported in the previous chapter. The $\mathbf{K}_{80}$ of sphalerite, galena and pyrite in the concentrator feed are $80 \%$ passing $150 \mu \mathrm{m}, 75 \mu \mathrm{m}$, and $425 \mu \mathrm{m}$, respectively (Table 17). This result may be compared with the actual grinds achieved. The data in Appendix 9 show about $82 \%$ passing $75 \mu \mathrm{m}$ in both the lead rougher feed and the lead scavenger tail, the latter being feed to the zinc circuit. Therefore pyrite in the feed should 


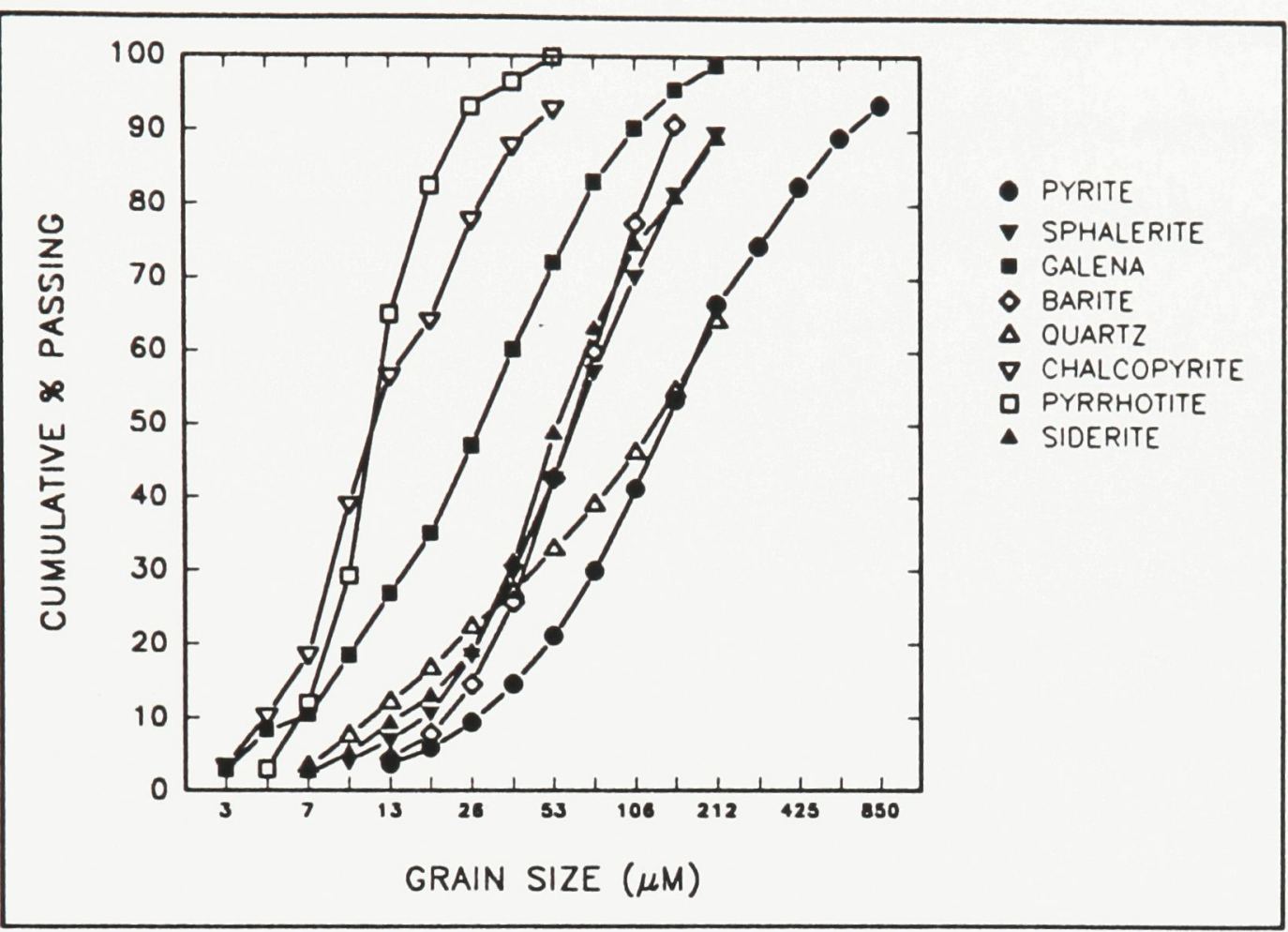

Figure 19 Grain size distributions of ore minerals in Faro concentrator feed.

be well liberated (Petruk 1986). The lead regrind circuit achieves $80 \%$ passing $38 \mu \mathrm{m}$ in the regrind cyclone overflow. Thus for galena the final grind is much finer than the galena grain size and liberation should be good. The size distribution of the zinc regrind cyclone overflow is $80 \%$ passing $38 \mu \mathrm{m}$ which is also much finer than the sphalerite grain size and so liberation for sphalerite is expected to be better than that of galena.

It is interpreted from the visually estimated ore mineral grain size distribution of tetrahedrite that the $\mathrm{K}_{80}$ is $150 \mu \mathrm{m}$. Liberation of tetrahedrite is predicted to be excellent.

Metal and Mineral Quantities and Recoveries

The balanced solid flowrates, in TPH, calculated by the materials balance program, BILMAT, are given in Appendix 8; the measured and balanced sieve analysis data ( +75 
$\mu \mathrm{m}, 75$ to $38 \mu \mathrm{m}$ and $-38 \mu \mathrm{m}$ ) are given in Appendix 9; and the measured and balanced assays and recoveries for lead, zinc, silver, antimony, copper and gold in each stream are given in Appendix 10 for each circuit. The balanced quantities of the major and minor minerals in each stream are given in Appendix 11.

\section{Liberation}

Particles produced by the breakage (comminution) of ore are either free, that is mono-minerallic, or locked. The main objective of grinding in mineral processing is to maximize the proportion of a particular ore mineral that is free.

Ore breakage theory acknowledges that all rocks contain flaws such as microscopic cracks and pores. These flaws constitute zones of weakness because they concentrate stress when under a compressive load (Meredith 1990). Under suitable stress, as that produced in a grinding mill, these microcracks, of various lengths, grow lengthwise very rapidly sometimes linking together to form a network. Their rate of growth is directly proportional to their length. The longest of the cracks will grow catastrophically to become macrocracks or fracture surfaces. Grain boundaries and cleavage planes also represent zones of weakness or paths of low fracture energy (Freiman and Swanson 1990, Bearman et al 1989). As a result, propagating cracks are locally deflected along these paths and minerals may liberate by preferential breakage. It has also been shown that as the tortuosity of growing microcracks increases they become more resistant to growth (Meredith 1990).

This theory of breakage leads to two pertinent points: the boundaries of large 
mineral grains will produce a fracture surface more readily than those of small grains and that planar mineral boundaries (good crystal habit) will encourage crack propagation. Petruk (1994) has further suggested that if the surface of grains are rough due to many embayments then the moving fracture tip will simply cut across the embayments resulting in the production of many small attached grains at the surface of a large host grain.

Many researchers in the field of mineral liberation maintain that ores break only in a random fashion, i.e. breakage is independent of texture, and that evidence to the contrary is notably lacking (King 1979, 1990, Klimpel and Austin 1983, Meloy and Gotoh 1985). Others hold that breakage is indeed dependent on texture (Petruk 1988b, Laslett et al 1990, Meredith 1990). Gaudin (1939) first noted that in industrial grinding mills minerals liberate by means of both processes, by random breakage, which he called liberation by size reduction, and by preferred breakage, which he called liberation by detachment. Petruk (1988b) maintains that breakage by detachment of grains from each other is predominant in industrial practice.

Random breakage implies breakage across grain boundaries which, because crystallographic bonds are much stronger than intergranular bonds, means that the process requires much more energy than preferred breakage. Therefore during grinding preferred breakage will normally take precedence over random breakage. Random breakage becomes significant only after most of the weaker intergranular bonds have been destroyed (Petruk 1988b). True random breakage requires that the ore be homogeneous and isotropic. Obviously, multi-minerallic ores which are composed of grains of varying size, hardness, brittleness, cleavability and habit are not homogeneous and isotropic at the 
granular scale. Therefore, it is expected that some minerals will suffer transgranular breakage more readily than others so that overall such breakage is not truly random.

It is expected that the average strength of the bond at grain boundaries between different minerals varies due to differences in physical properties of the adjacent minerals (Gaudin 1939, Barbery et al 1983). Therefore some mineral pairs will break apart more readily than others.

Because the nature of the contact between mineral grains is so significant in breakage, mineral association is an important factor in analyzing liberation. Hence application of the technique of mineral association by perimeter to mineral breakage, developed in this thesis, provides a very important parameter for understanding preferential breakage between mineral pairs.

Liberation of an ore mineral has been defined as the proportion of mineral which is free (Gaudin 1939). Due to the nature of ore breakage, as discussed above, complete liberation is never attained in practice. In fact, in commercial concentrates a large portion of the desirable ore mineral resides in locked particles. It is therefore more meaningful to quantify mineral liberation as the weight distribution of the ore mineral among various grades of locked particles. In this study the locked particles are graded according to the areal proportion the ore mineral occupies in a particle as observed in the polished section. The grades are defined by ranges from $0-10 \%, 10-20 \%, \ldots, 90-99.99 \%$. By combining this distribution with the proportion of free particles, a liberation spectrum is obtained.

The proportion of free particles in the flat surface of a polished section is not a measure of the true liberation because of the bias created by the slicing effect. This bias 
results from the fact that a small portion of the randomly oriented locked particles will appear free but none of the free particles will appear locked. To a certain degree this effect extends also to the various grades of locked particles. Stereological corrections to adjust for this bias exist but they are not well defined and can lead to large errors if applied incorrectly (Miller et al 1988). The liberation data shown in this work are uncorrected and therefore the quantity of free grains reported is overestimated by a small unknown amount (probably 1 to $10 \%$ relative, (Petruk 1986)). Petruk notes that the error is minimized if the particles have a wide size distribution. Therefore the samples used in this study were not sieved at closely-spaced sieve size intervals. Nevertheless, the uncorrected data are still self-consistent and are used comparatively in this study.

\section{Liberation of Sphalerite and Galena}

The liberation spectrums of sphalerite and galena were measured by means of the image analyzer in all the concentrator samples. It has been shown (Petruk 1989) that a sphalerite concentrate, grading about $52 \% \mathrm{Zn}$, tends to recover sphalerite-bearing particles that grade $70 \%$ or more. Therefore sphalerite-bearing particles containing 70 to $100 \%$ sphalerite will be classified as "liberated" sphalerite. Similarly, galena-bearing particles containing 70 to $100 \%$ galena will be classified as "liberated" galena. Particles containing either $100 \%$ sphalerite or $100 \%$ galena will be referred to as "free" sphalerite and "free" galena, respectively. For ease in data handling and interpretation the particle grades are grouped into three classes: a tailings class, which includes particle grades from 0 to $20 \%$; a middlings class, including grades from 20 to $70 \%$; and a "liberated" class, including 
grades from 70 to $100 \%$. On this basis the liberation data were balanced for galena and sphalerite within each particle sieve size and are shown in TPH in Tables 18 and 19.

Liberation and Distributions of Sphalerite and Galena in the Lead Flotation Circuit Rougher-scavenger flotation

The basic operating strategy of lead rougher-scavenger flotation is to maximize recovery of galena. By recovering only those particles which contain galena and rejecting the rest the efficiency of the subsequent regrinding step is improved.

The rougher cells recover, to the rougher concentrate, $77 \%$ of the galena and $31 \%$ of the sphalerite in the rougher feed (Figures 20 and 21 ). The best galena recovery by the roughers is obtained in the $-38 \mu \mathrm{m}$ sieve fraction (Figure 22). The lead rougher concentrate contains 29 tonnes per hour (TPH) galena of which $79 \%$ is "liberated" and 28 TPH sphalerite of which $75 \%$ is "liberated" (Table 18 and Figure 23). The galena reporting to the rougher tails amounts to $8 \mathrm{TPH}$ of which about $37 \%$ is "liberated" (Figure 23).

The scavenger cells recover $46 \%$ of the galena in the scavenger feed which results in a combined rougher-scavenger galena recovery of $86 \%$ (Figure 20 ). The remaining $14 \%$ of the galena which is lost to the scavenger tails is predominantly $(78 \%)$ locked in middlings and tailings particles (Figure 23 shows $22 \%$ "liberated"). Most of this galena is in the $+38 \mu \mathrm{m}$ sieve fraction (Table 18).

The lead scavengers distribute $21 \%$ of the sphalerite in the scavenger feed to the scavenger concentrate (Figure 21). Much of this sphalerite (75\%) is "liberated" (Figure 
TABLE 18

LIBERATION ANALYSIS OF THE LEAD CIRCUIT OF THE FARO CONCENTRATOR (TPH)

Rougher feed

Rougher Conc.

Rougher Tail

Scavenger Conc.

Scavenger Tail

Cyclone U/F

Regrind Disch.

Cyclone O/F

First Cleaner Conc.

First Cleaner Tail

Second Cleaner Conc.

Second Cleaner Tail

Third Cleaner Tail

Third Cleaner Conc.

Liberated Galena

$\begin{array}{rrr}+73 \mu m & -75+38 \mu \mu & -38 \mu \mu \\ .24 & 3.52 & 17.42 \\ .14 & 3.37 & 19.03 \\ .20 & .69 & 2.20 \\ .07 & .23 & 1.79 \\ .13 & .45 & .41 \\ 1.03 & 10.82 & 45.83 \\ .95 & 8.21 & 47.80 \\ .06 & .77 & 21.00 \\ .12 & 4.48 & 26.72 \\ .03 & .31 & 2.02 \\ .06 & 2.31 & 26.24 \\ .09 & 4.01 & 7.74 \\ .03 & 1.85 & 7.26 \\ .03 & .46 & 18.98\end{array}$

Middling Galena

Rougher Feed

Rougher Conc.

Rougher Tail

Scavenger Conc.

Scavenger Tail

Cyclone U/F

Regrind Disch.

Cyclone O/F

First Cleaner Conc.

First Cleaner Tail

Second Cleaner Conc.

Second Cleaner Tail

Third Cleaner Tail

Third Cleaner Conc.

$$
\begin{array}{r} 
\\
+7 \\
. \\
. \\
. \\
. \\
. \\
. \\
. \\
. \\
.09 \\
.07 \\
. \\
.
\end{array}
$$

$-75+384 \mu$
1.00

$\begin{array}{rr}1.00 & 1.77 \\ 1.30 & 2.47 \\ .59 & .32\end{array}$

$.59 \quad .32$

$.28 \quad .29$

.31

4.15

3.65

.80

1.49

.61

.82

.63

.19

.03
4.29

5.04

3.22

3.19

.73

3.38

.70

.89

2.49

Tailing Galena

$$
+75 \mu \mathrm{m}
$$

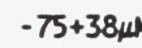

\subsection{5 \\ .22}

Rougher Conc.

Rougher Tail

Scavenger Conc.

Scavenger Tail

Cyclone U/F

Regrind Disch.

Cyclone O/F

First Cleaner Conc.

First Cleaner Tail

Second Cleaner Conc.

Second Cleaner Tail

Third Cleaner Tail

Third Cleaner Conc.

Liberated Sphalerite

$\begin{array}{rrr}+75 \mu m & -75+38 \mu \mu & -38 \mu \mu \\ 6.11 & 13.88 & 23.33 \\ 1.02 & 6.10 & 14.01 \\ 6.11 & 12.75 & 32.18 \\ .79 & 2.26 & 6.72 \\ 5.32 & 10.49 & 25.47 \\ 3.20 & 11.78 & 11.32 \\ 2.47 & 8.63 & 16.56 \\ .29 & 2.96 & 19.25 \\ .52 & 9.00 & 21.81 \\ .23 & 2.72 & 16.14 \\ .28 & 2.16 & 10.65 \\ .46 & 8.77 & 18.69 \\ .22 & 1.93 & 7.54 \\ .06 & .24 & 3.11\end{array}$

Middling Sphalerite

$\begin{array}{rrr}+75 \mu \mathrm{m} & -75+38 \mu \mu & -38 \mu \mu \\ 1.54 & 2.45 & 2.39 \\ .42 & 1.77 & 2.12 \\ 1.44 & 1.97 & 3.11 \\ .26 & .63 & .90 \\ 1.18 & 1.34 & 2.21 \\ 1.08 & 4.59 & 4.63 \\ .73 & 3.52 & 5.18 \\ .07 & .71 & 2.67 \\ .17 & 1.94 & 4.22 \\ .06 & .66 & 1.94 \\ .06 & .51 & 2.11 \\ .16 & 1.90 & 3.49 \\ .05 & .46 & 1.39 \\ .01 & .05 & .73\end{array}$

Tailing Sphalerite

$+75 \mu \mathrm{m} \quad-75+38 \mu \mathrm{m} \quad-38 \mu \mathrm{m}$

.51

.06

.51

.04

.47

.21

.17

.02

.02

.02

.01

.02

.01
2.16

2.37

2.95

1.26

1.69

2.52

2.81

2.66

4.15

1.90

2.02

3.38

1.26 
TABLE 19

LIBERATION ANALYSIS OF THE ZINC CIRCUIT OF THE FARO CONCENTRATOR (TPH)

Liberated Galena

$\begin{array}{ccc}+75 \mu \mathrm{m} & -75+38 \mu \mu & -38 \mu \mu \\ .03 & .29 & .47 \\ .01 & .05 & .10 \\ .03 & .35 & .57 \\ .02 & .18 & .30 \\ .02 & .16 & .27 \\ .01 & .11 & .17 \\ .00 & .13 & .90 \\ .01 & .28 & .58 \\ .00 & .03 & .63 \\ .02 & .27 & 1.67 \\ .02 & .30 & 2.10 \\ .00 & .01 & .20 \\ .00 & .13 & 1.17 \\ .00 & .11 & .75 \\ .00 & .02 & .43 \\ .02 & .12 & .37\end{array}$

Liberated Sphalerite

$\begin{array}{rrr}+75 \mu m & -75+38 \mu \mu & -38 \mu \mu \\ 4.45 & 10.37 & 25.24 \\ 1.05 & 1.09 & 1.27 \\ 5.50 & 11.46 & 26.51 \\ 3.99 & 10.26 & 24.92 \\ 1.51 & 1.20 & 1.59 \\ .47 & .11 & .32 \\ 2.81 & 14.91 & 34.29 \\ 5.97 & 18.60 & 26.51 \\ .83 & 6.57 & 32.70 \\ 6.34 & 18.40 & 6.39 \\ 6.52 & 23.93 & 36.86 \\ .65 & 1.04 & 2.23 \\ 3.25 & 20.85 & 41.97 \\ 3.07 & 15.32 & 11.50 \\ .18 & 5.53 & 30.47 \\ 1.11 & 1.16 & 2.56\end{array}$

Lead Scavenger Tail Scavenger Conc.

Rougher feed

Rougher Conc.

Rougher Tail

Scavenger Tail

Regrind Disch.

Cyclone Underflow

Cyclone Overflow

Second Cleaner Tail

First Cleaner Conc.

First Cleaner Tail

Second Cleaner Conc.

Third Cleaner Tail

Third Cleaner Conc.

Final Tail
Middling Galena

$\begin{array}{cc}+75 \mu \mathrm{m} & -75+38 \mu \mathrm{m} \\ .10 & .11 \\ .03 & .03 \\ .12 & .13 \\ .04 & .08 \\ .08 & .05 \\ .06 & .02 \\ .02 & .17 \\ .05 & .19 \\ .01 & .05 \\ .11 & .38 \\ .11 & .41 \\ .01 & .02 \\ .03 & .22 \\ .02 & .19 \\ .00 & .03 \\ .07 & .05\end{array}$

Tailing Galena

$\begin{array}{ccc}+75 \mu \mathrm{m} & -75+38 \mu \mathrm{M} & -38 \mu \mathrm{M} \\ .50 & .47 & .45 \\ .11 & .09 & .02 \\ .61 & .56 & .48 \\ .11 & .35 & .23 \\ .50 & .21 & .24 \\ .39 & .12 & .22 \\ .05 & .16 & .15 \\ .13 & .41 & .16 \\ .03 & .11 & .22 \\ .24 & .72 & .20 \\ .25 & .75 & .34 \\ .02 & .07 & .09 \\ .05 & .31 & .32 \\ .05 & .28 & .18 \\ .01 & .04 & .13 \\ .41 & .19 & .31\end{array}$

Middling Sphalerite

$\begin{array}{rrr}+75 \mu \mathrm{m} & -75+38 \mu \mathrm{m} & -38 \mu \mathrm{m} \\ .75 & 1.23 & .80 \\ .34 & .30 & .13 \\ 1.08 & 1.33 & .94 \\ .53 & 1.00 & .75 \\ .56 & .33 & .18 \\ .22 & .02 & .05 \\ .21 & .93 & .76 \\ .57 & 1.46 & .59 \\ .17 & .47 & .92 \\ .80 & 3.22 & .68 \\ .80 & 3.41 & 1.46 \\ .17 & .28 & .15 \\ .13 & 1.34 & 1.42 \\ .13 & 1.15 & .65 \\ .86 & .19 & .77 \\ .39 & .31 & .20\end{array}$

Tailing Sphalerite

$\begin{array}{ccc}+\pi 5 \mu m & -75+38 \mu m & -38 \mu m \\ .40 & .28 & .31 \\ .06 & .12 & .03 \\ .46 & .40 & .34 \\ .07 & .24 & .18 \\ .39 & .16 & .16 \\ .33 & .04 & .13 \\ .06 & .23 & .08 \\ .10 & .31 & .14 \\ .02 & .17 & .12 \\ .13 & .67 & .14 \\ .13 & .68 & .22 \\ .02 & .16 & .05 \\ .01 & .18 & .24 \\ .01 & .17 & .16 \\ .00 & .01 & .08 \\ .35 & .20 & .18\end{array}$




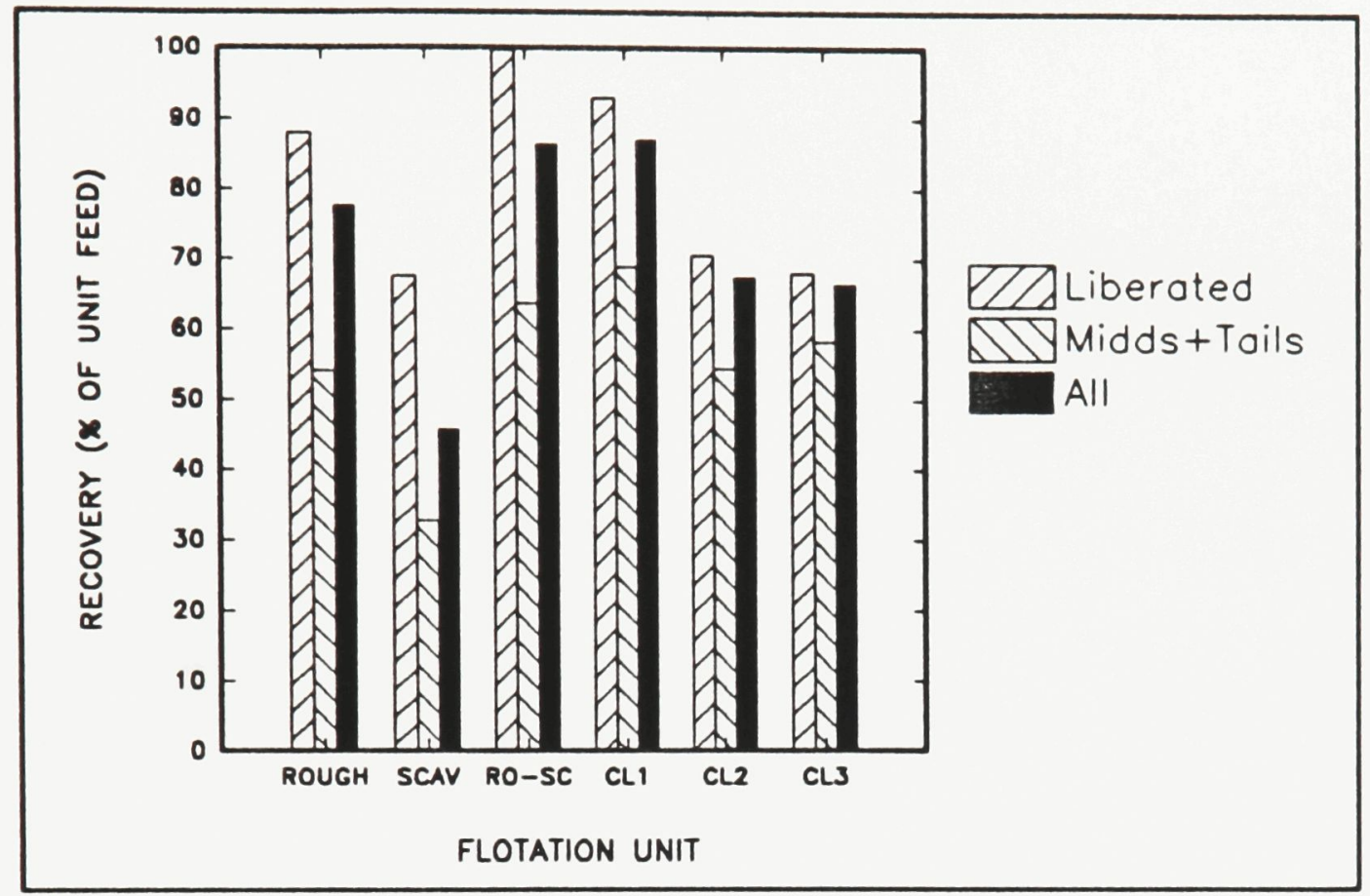

Figure 20 Galena recovery by liberation class in Faro lead circuit.

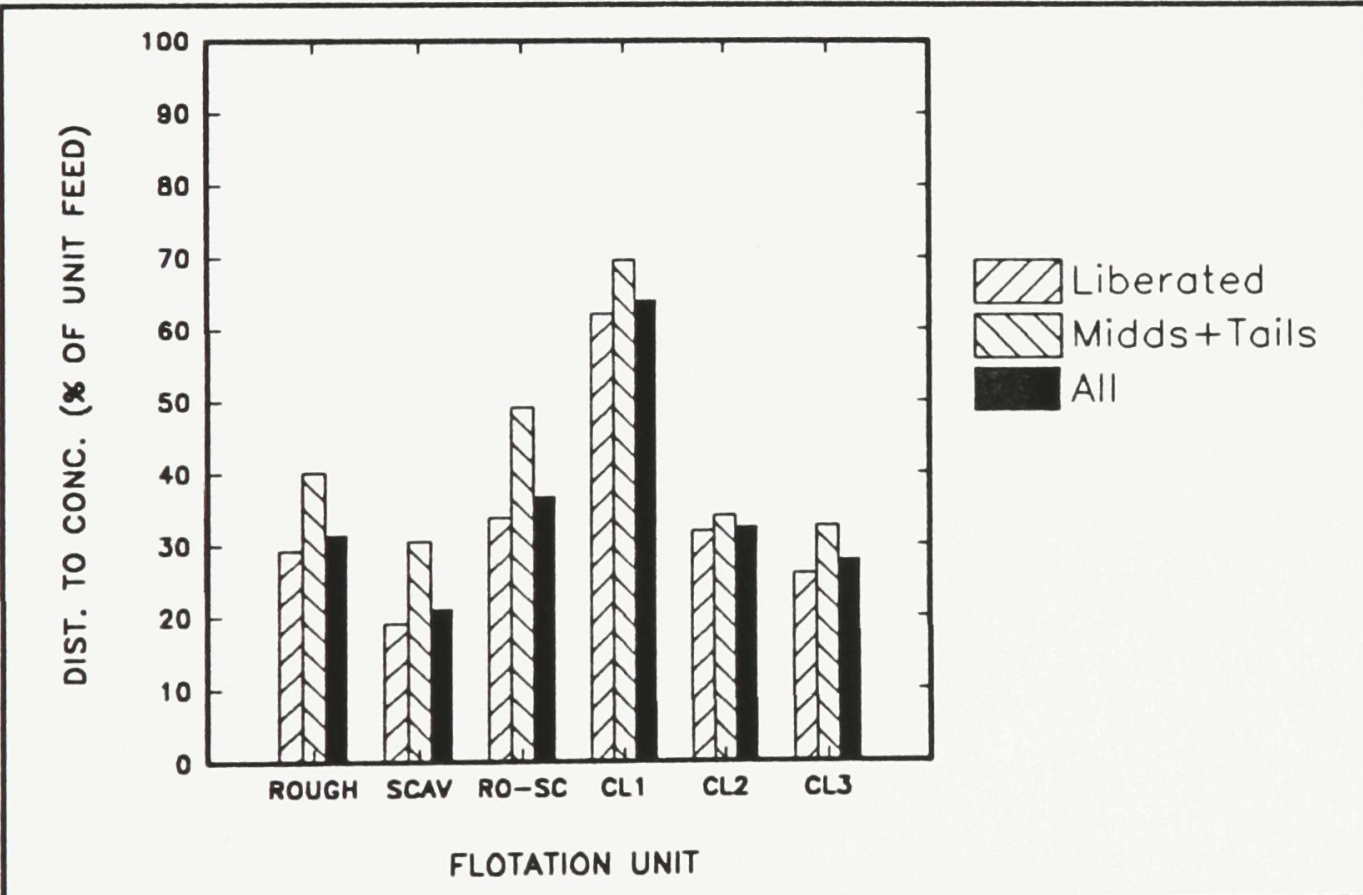

Figure 21 Sphalerite distribution by liberation class in Faro lead circuit. 


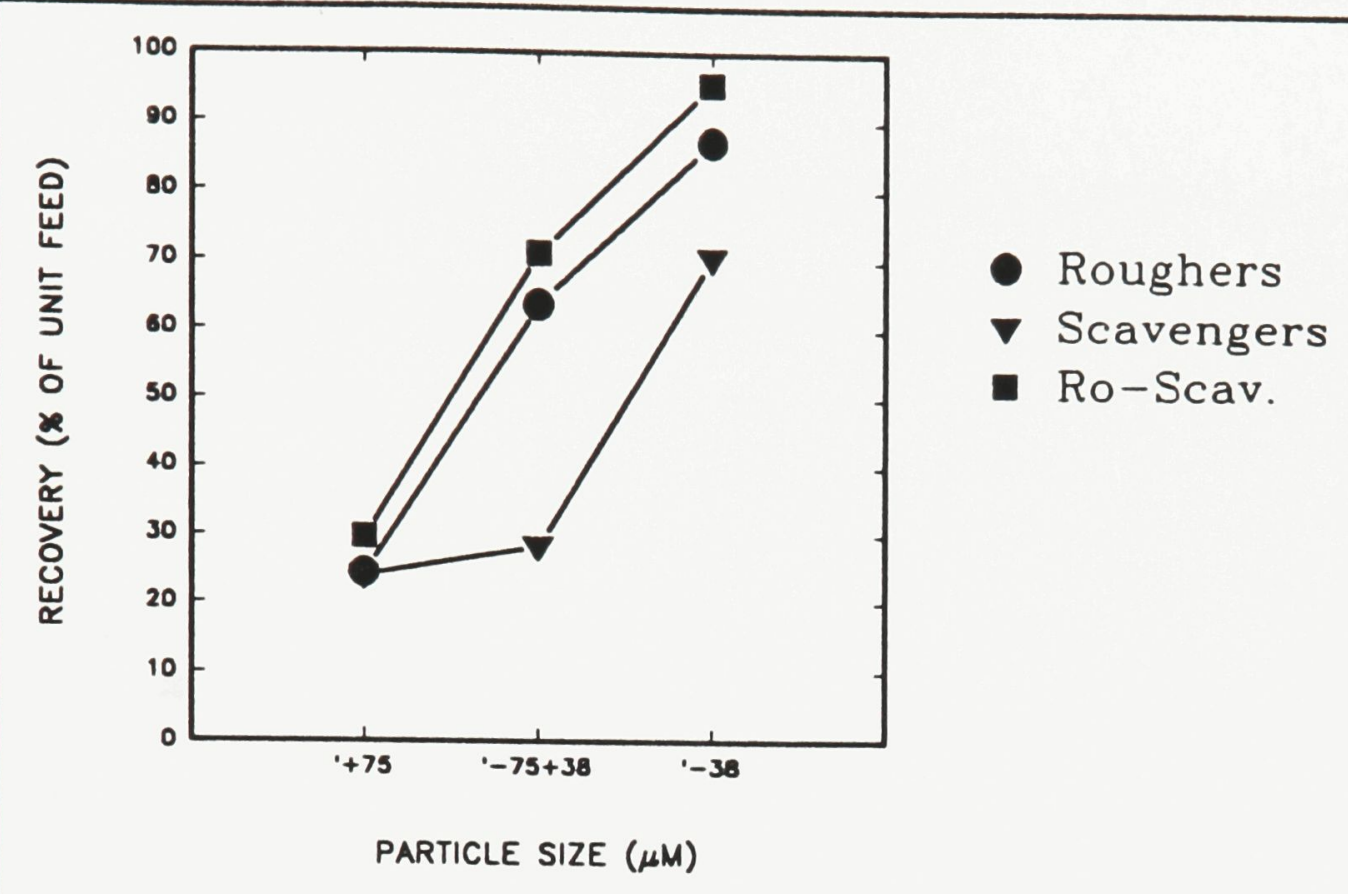

Figure 22 Galena recovery by size in Faro lead circuit.

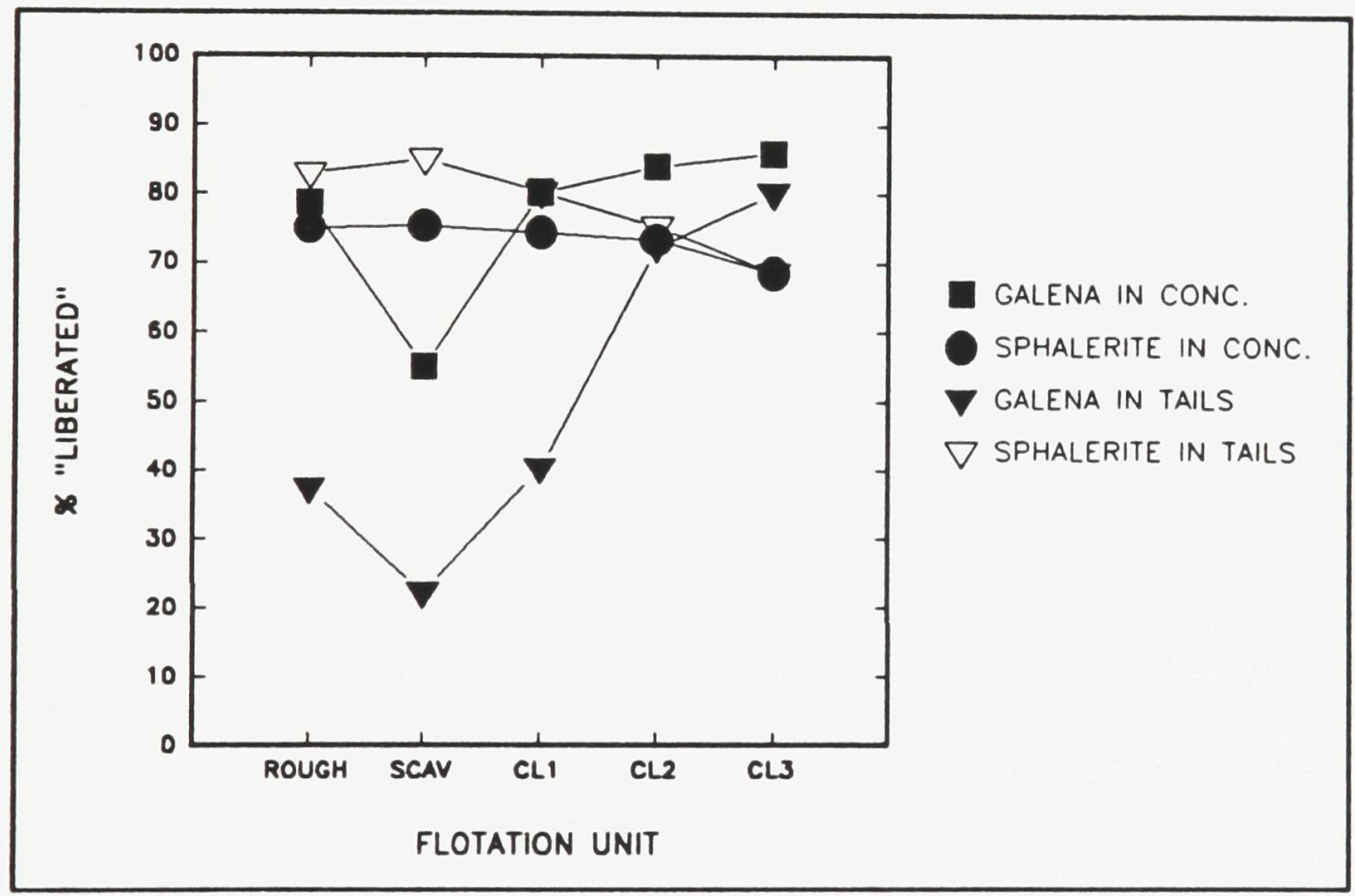

Figure 23 Percent "liberated" in flotation streams of Faro lead circuit. 
23). The combined rougher-scavenger sphalerite distribution to the lead rougher concentrate is $37 \%$ (Figure 21 ).

The "liberation" of pyrite in the concentrator feed is over $90 \%$ (Figure 24). As a result pyrite rejection to the lead scavenger tails is almost $83 \%$. Siderite rejection is $87 \%$ and quartz rejection is $96 \%$.

Hydrocyclone - regrind ball mill

The basic operating strategy of the $\mathrm{Pb}$ regrind circuit is to selectively regrind locked particles. The purpose of the hydrocyclone is to separate and redirect the coarse particles to the regrind ball mill. Operating parameters of the lead regrind mill are given in Appendix 7. It was calculated that the hydrocyclone distributes to the underflow $71 \%$ of the galena in the total cyclone feed (Figure 25). The galena distributions to the underflow for the "liberated", middling and tailing classes are $73 \%, 69 \%$ and $49 \%$, respectively (Figure 25). Distributions of "liberated" galena in the size intervals $+75 \mu \mathrm{m},-$ $75+38 \mu \mathrm{m}$ and $-38 \mu \mathrm{m}$ are: $94 \%, 93 \%$ and $69 \%$ whereas those for tailing galena are: $74 \%, 68 \%$ and $29 \%$. The high proportion of fine-grained "liberated" particles distributed to the underflow indicates that the separating action of the hydrocyclone is not only based on particle size but also particle density. Hence, some large galena-gangue particles which require regrind tend to bypass the mill in the overflow and those galena grains which are already liberated tend to be reground. The efficiency of the mill is thereby reduced. $78 \%$ of the galena in the feed to the regrind circuit (rougher conc.) is "liberated" and $77 \%$ in the regrind circuit product (cyclone overflow) is "liberated", indicating, within 


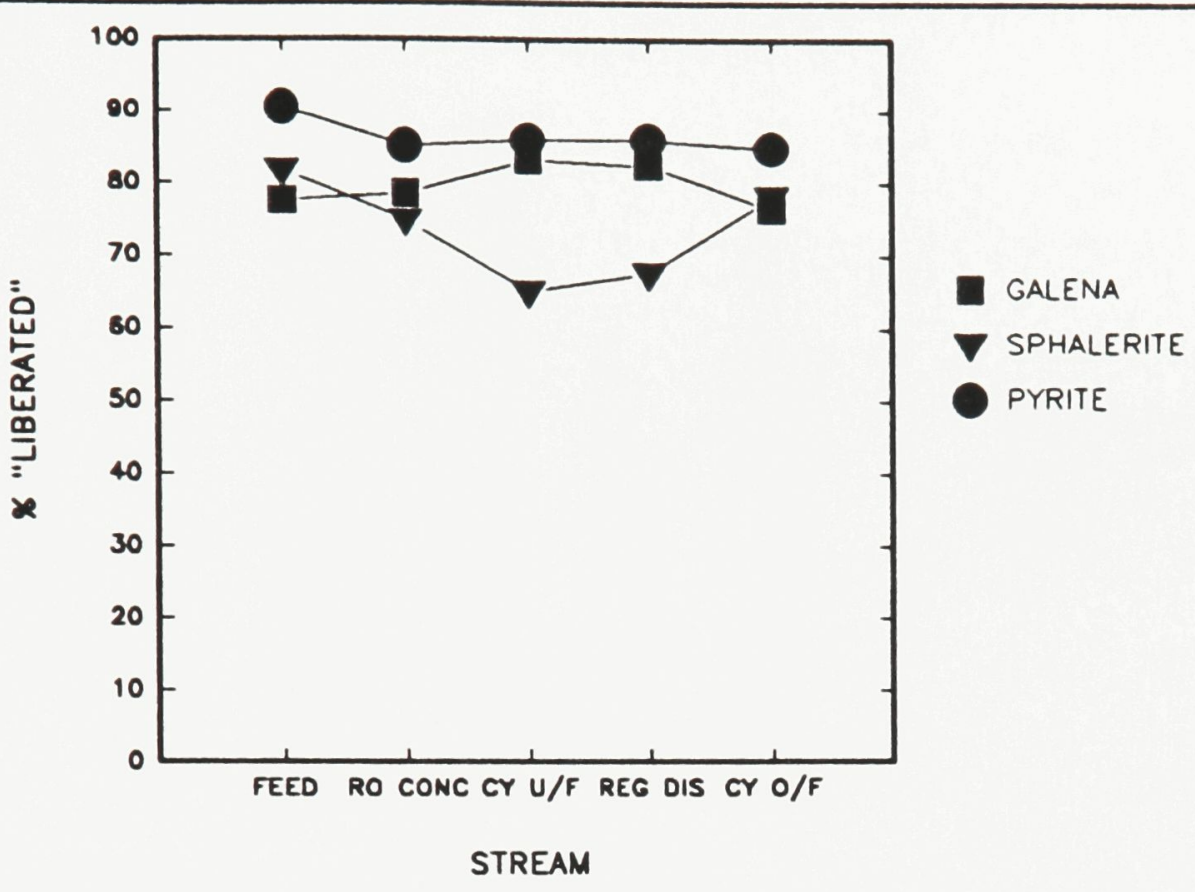

Figure 24 Percent "liberated" in selected streams of Faro lead circuit.

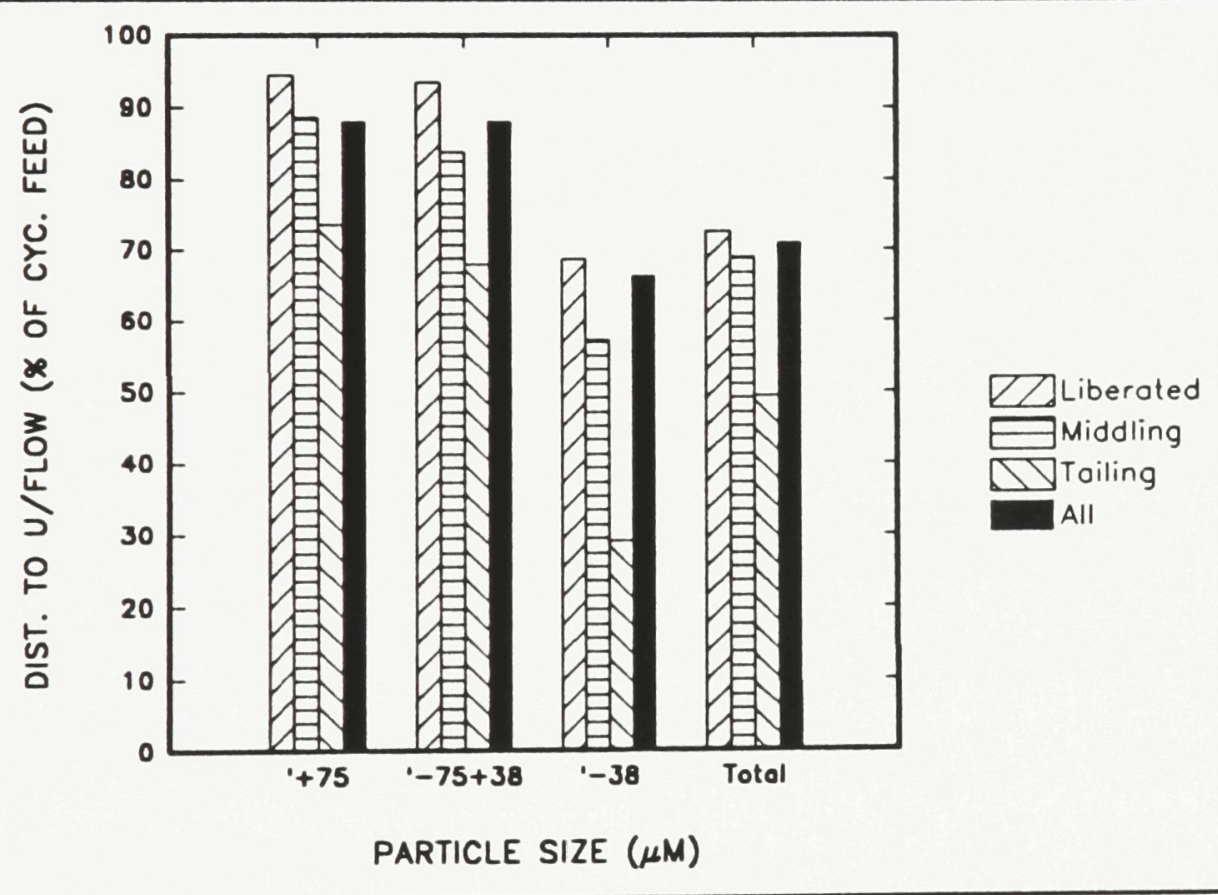

Figure 25 Galena distribution by liberation class and size to Faro lead regrind cyclone underflow. 


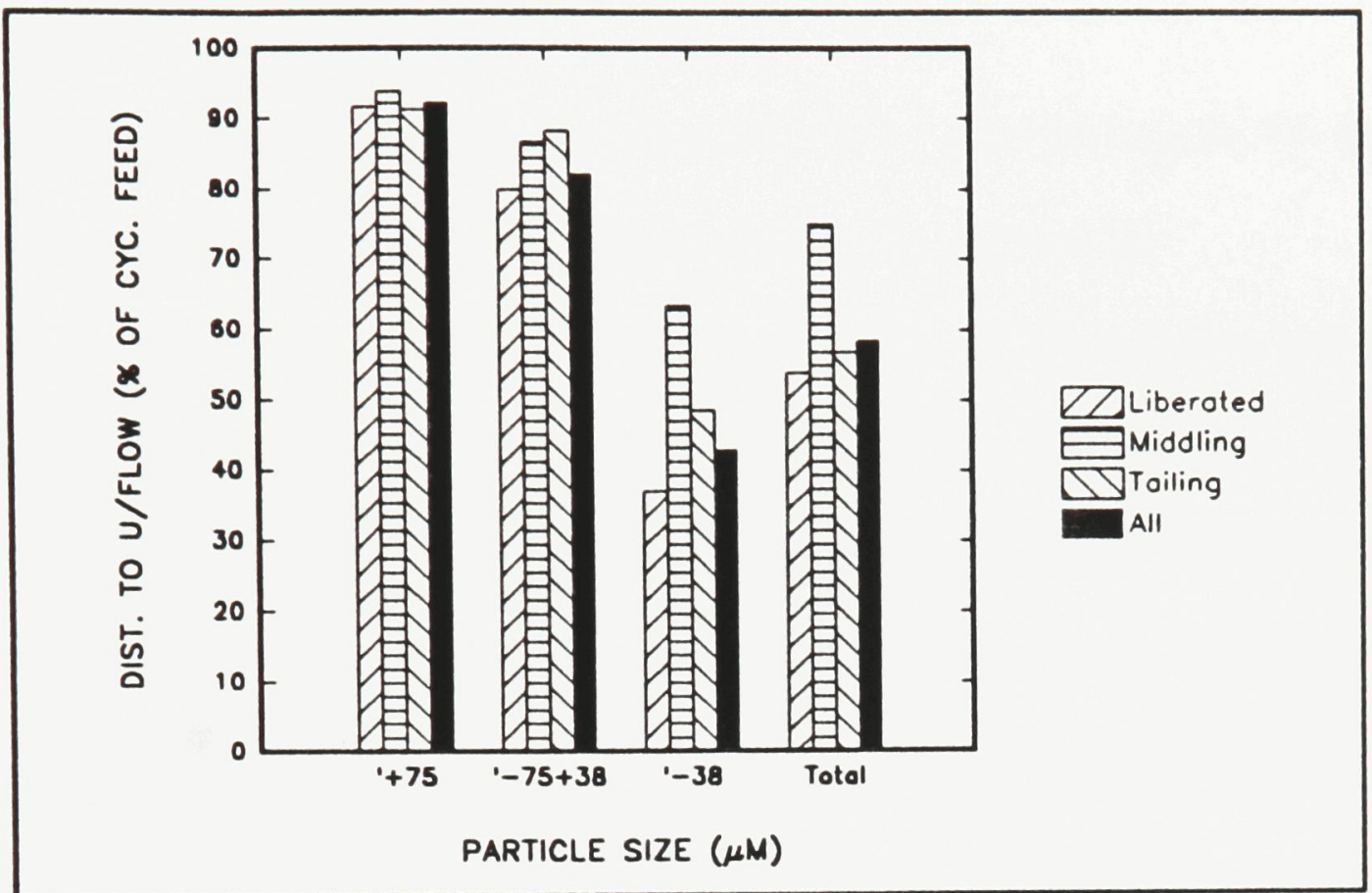

Figure 26 Sphalerite distribution by liberation class and size to Faro lead regrind cyclone underflow.

experimental error, no measurable increase in galena liberation (Figure 24).

The proportion of sphalerite in the cyclone feed which is distributed to the cyclone underflow is $58 \%$ (Figure 26). Sphalerite distributions for the "liberated", middling and tailings classes are $54 \%, 75 \%$ and $57 \%$, respectively. Distributions of "liberated" sphalerite in the size intervals $+75 \mu \mathrm{m},-75+38 \mu \mathrm{m}$ and $-38 \mu \mathrm{m}$ are: $92 \%, 80 \%$ and $37 \%$ whereas those for tailing sphalerite are: $91 \%, 88 \%$ and $49 \%$. Sphalerite "liberation" increases slightly from $75 \%$ to $78 \%$ across the regrind circuit (Figure 24 ). It is noteworthy that a check on the liberation of pyrite also showed no measurable increase (Figure 24). Although Appendix 9 shows that size reduction is occurring in the regrind mill the result is only a minimal increase in liberation for galena, sphalerite and pyrite. 
Lead cleaners

The objective of cleaning is to increase final concentrate grade by rejecting middling and tailing class galena particles as well as gangue minerals.

In the first cleaners recovery of "liberated" galena is $93 \%$ whereas recovery of unliberated galena (0-70\% classes) is $69 \%$ (Figure 20). Distribution of "liberated" sphalerite to the first cleaner concentrate is $62 \%$ of the "liberated" sphalerite in the first cleaner feed (Figure 21). These data show poor rejection of unliberated galena and sphalerite by the first cleaners. Table 18 shows that the first cleaners reject to tails 6 TPH of galena of which $40 \%$ is "liberated" (Figure 23).

In the second cleaners $71 \%$ of "liberated" galena in the second cleaner feed is recovered whereas the recovery of locked galena ( $0-70 \%$ classes) is $55 \%$ (Figure 20). $31 \%$ of the sphalerite in the second cleaner feed floats to the second cleaner concentrate (Figure 21). As in the first cleaners cleaning action is still not efficient for locked galena.

In the third cleaners "liberated" galena recovery is $68 \%$ of "liberated" galena in the third cleaner feed whereas locked galena ( $0-70 \%$ classes) recovery is still relatively high at $58 \%$ (Figure 20). Sphalerite distribution by the third cleaners to the final lead concentrate is $28 \%$ (Figure 21 ).

Liberation and Distributions of Sphalerite and Galena in the Zinc Flotation Circuit Rougher-scavenger flotation

The zinc rougher cells recover $87 \%$ of the sphalerite (Figure 27) and distribute $47 \%$ of the galena to the zinc rougher concentrate (Figure 28 ). The best sphalerite 


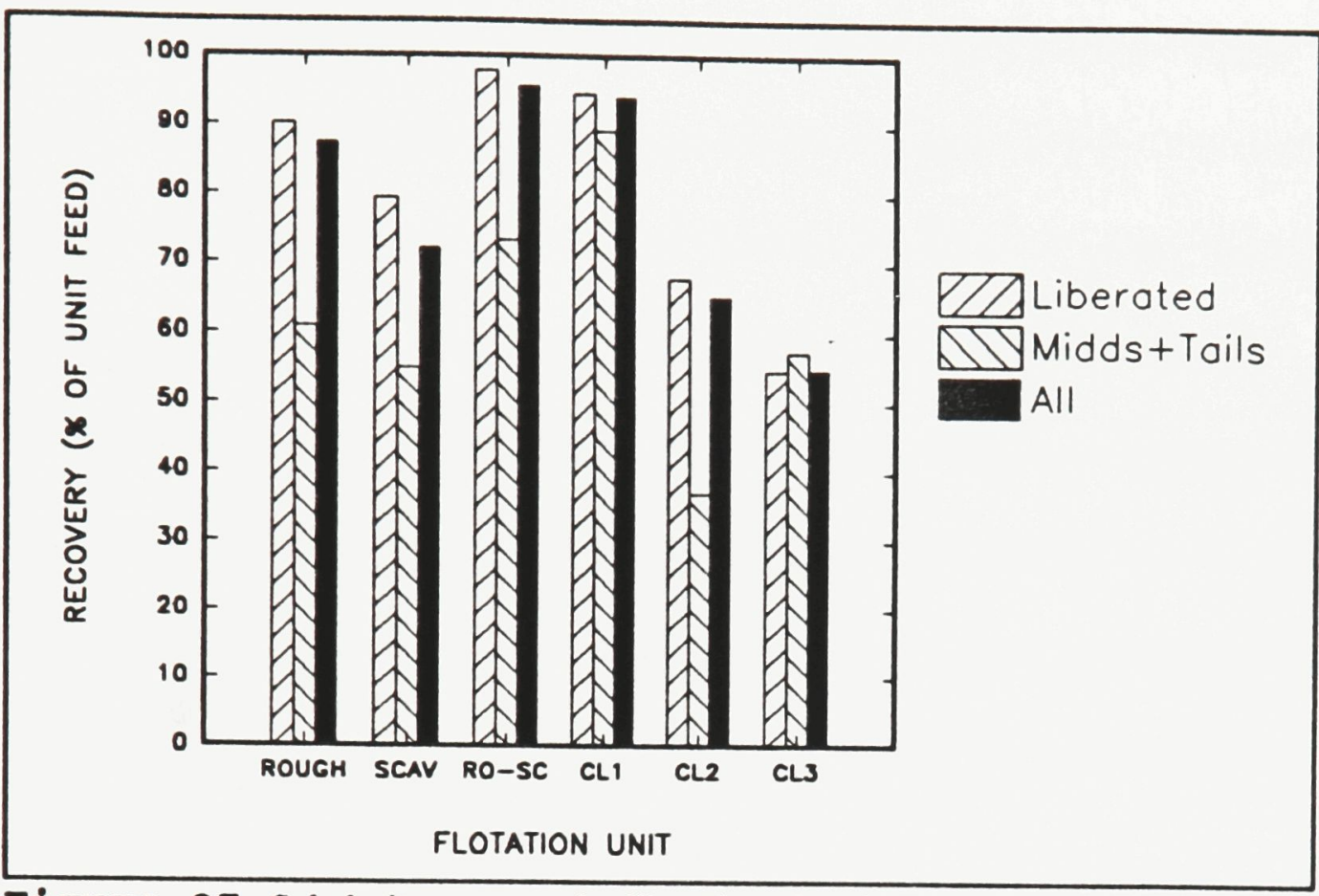

Figure 27 Sphalerite recovery by liberation class in Faro zinc circuit.

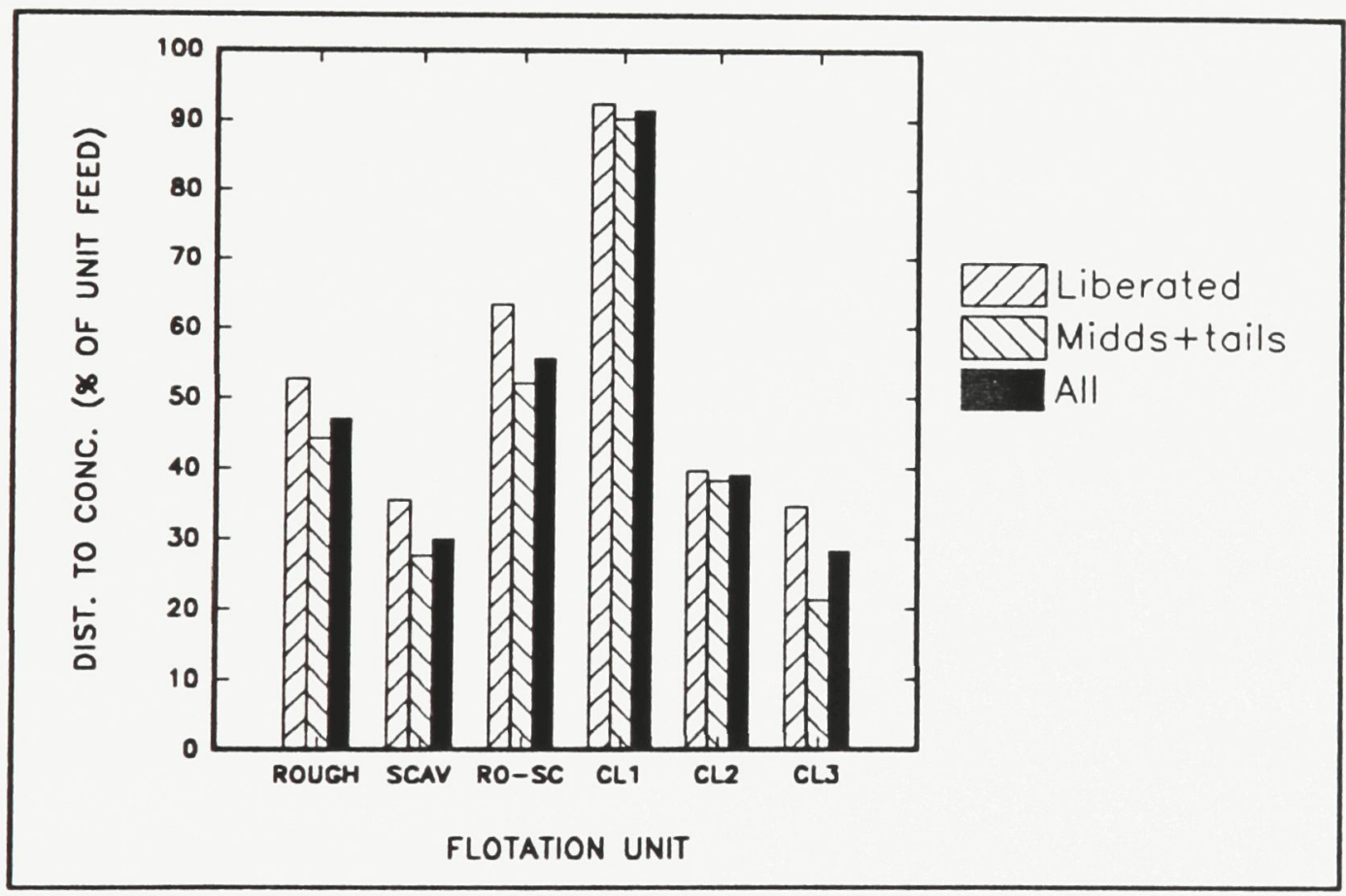

Figure 28 Galena distribution by liberation class in Faro zinc circuit. 
recovery by the roughers, $93 \%$, is obtained in the $-38 \mu \mathrm{m}$ sieve fraction (Figure 29). The zinc rougher concentrate contains 42 TPH sphalerite of which 93\% is "liberated" (Table 19 and Figure 30). The galena content is insignificant. The sphalerite reporting to the zinc rougher tails amounts to 6 TPH of which about $71 \%$ is liberated (Figure 30).

The scavenger cells recover $72 \%$ of the sphalerite in the scavenger feed resulting in a combined rougher-scavenger sphalerite recovery of $96 \%$ (Figure 27). The remaining $4 \%$ of the sphalerite which is lost to the scavenger tails is predominantly (53\%) "liberated" (Figure 30). The rougher-scavengers distribute $56 \%$ of the galena to the rougher concentrate (Figure 28).

Hydrocyclone - regrind ball mill

$56 \%$ of the sphalerite in the cyclone feed reports to the underflow (Figure 32). The sphalerite distributions for the liberated, middling and tailing classes are $56 \%, 63 \%$ and $64 \%$, respectively (Figure 32 ). Sphalerite "liberation" is $93 \%$ in the feed to the regrind circuit (ROUGH CONC in Figure 30) and $96 \%$ in the circuit product (CY O/F), indicating a small increase in liberation (Figure 33).

Galena distribution to the cyclone underflow is 62\% (Figure 31). Galena distributions for the liberated, middling and tailings classes are $57 \%, 70 \%$ and $67 \%$, respectively. Galena "liberation" increases from $36 \%$ to $58 \%$ across the regrind circuit (Figure 33). 


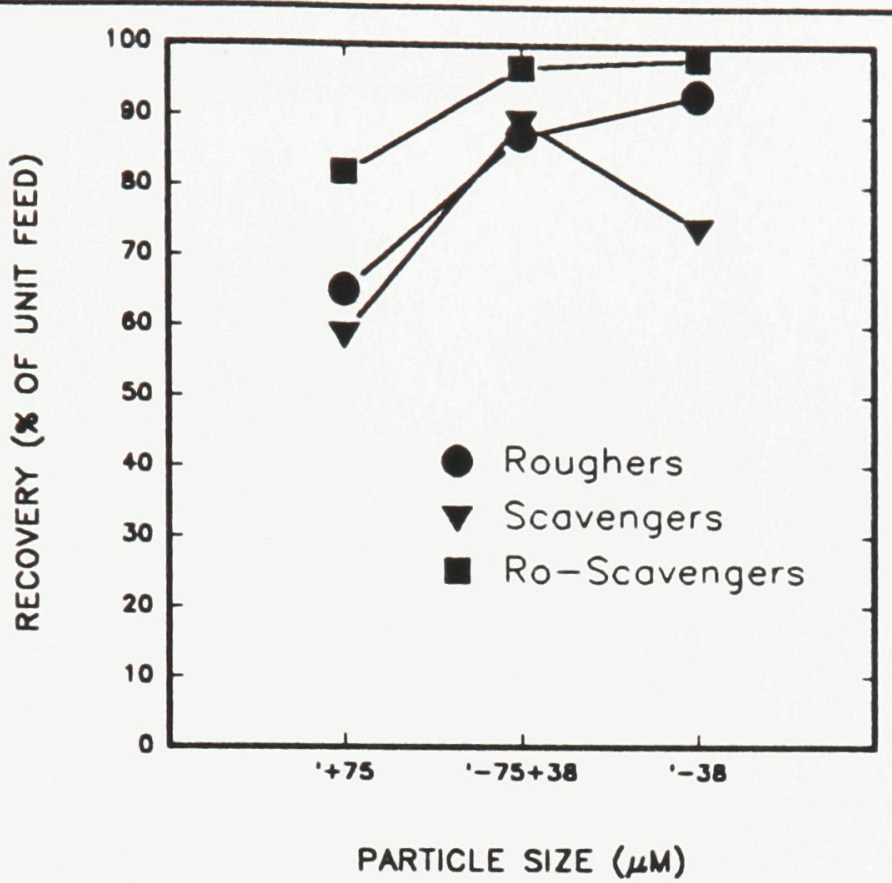

Figure 29 Sphalerite recovery by size in Faro zinc circuit.

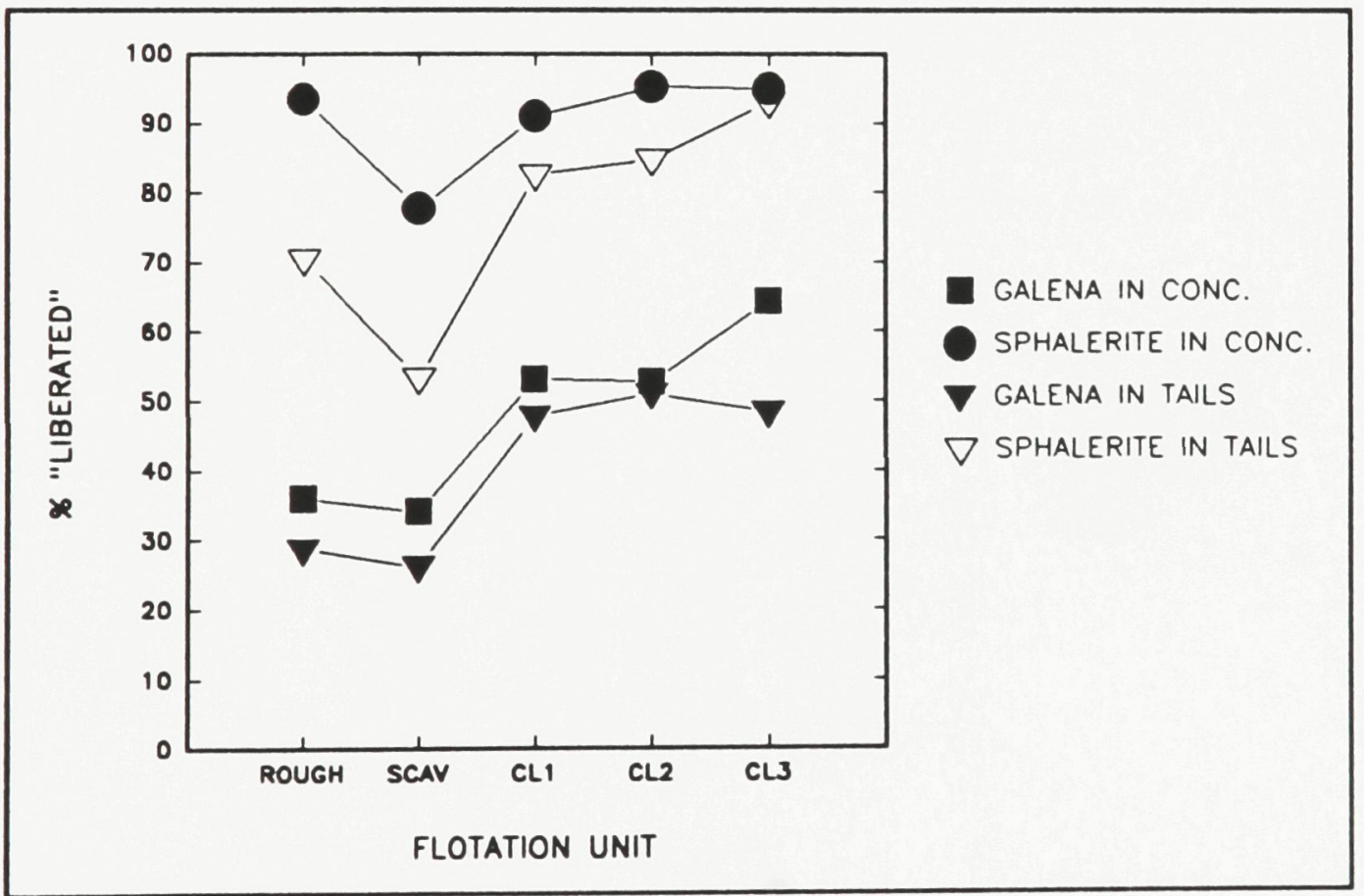

Figure 30 Percent "liberated" in flotation streams of Faro zinc circuit. 


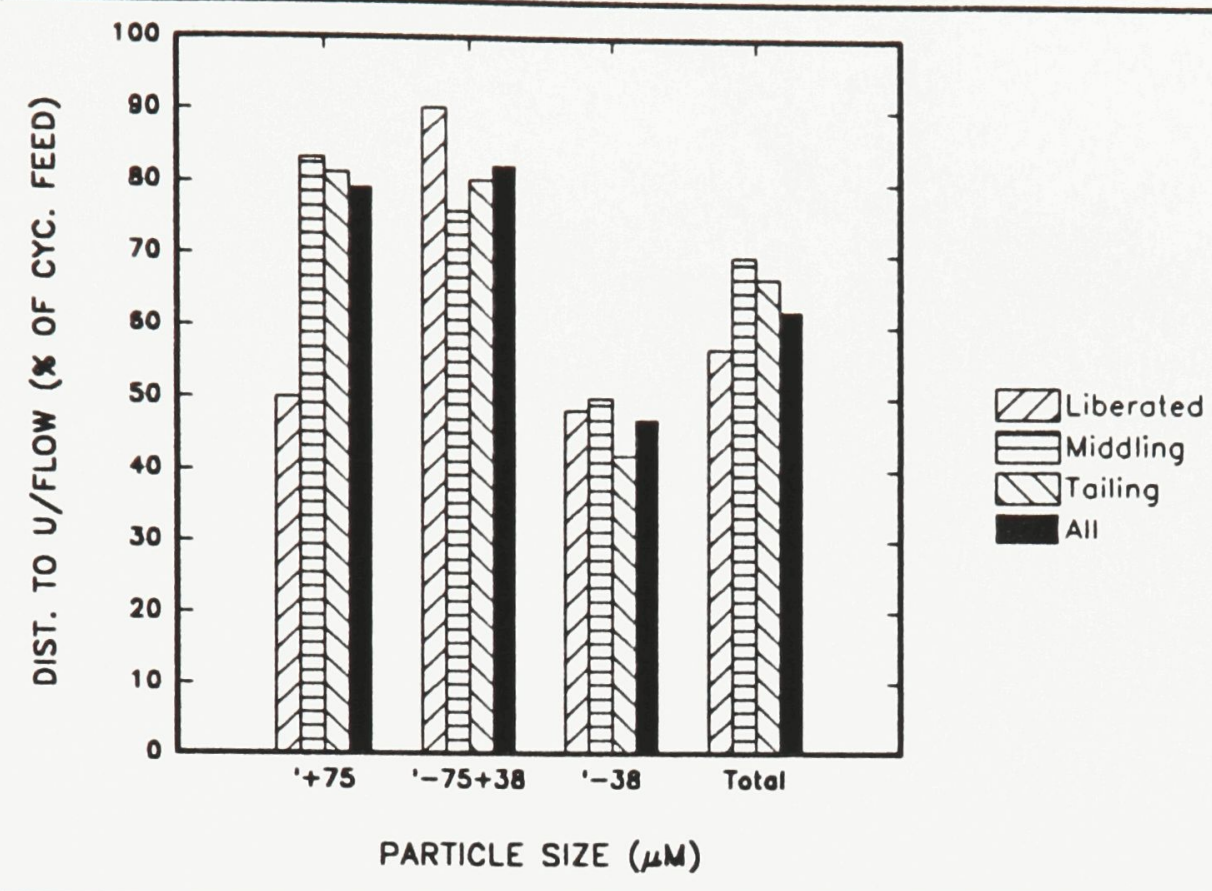

Figure 31 Galena distribution by liberation class and size to Faro zinc regrind cyclone underflow.

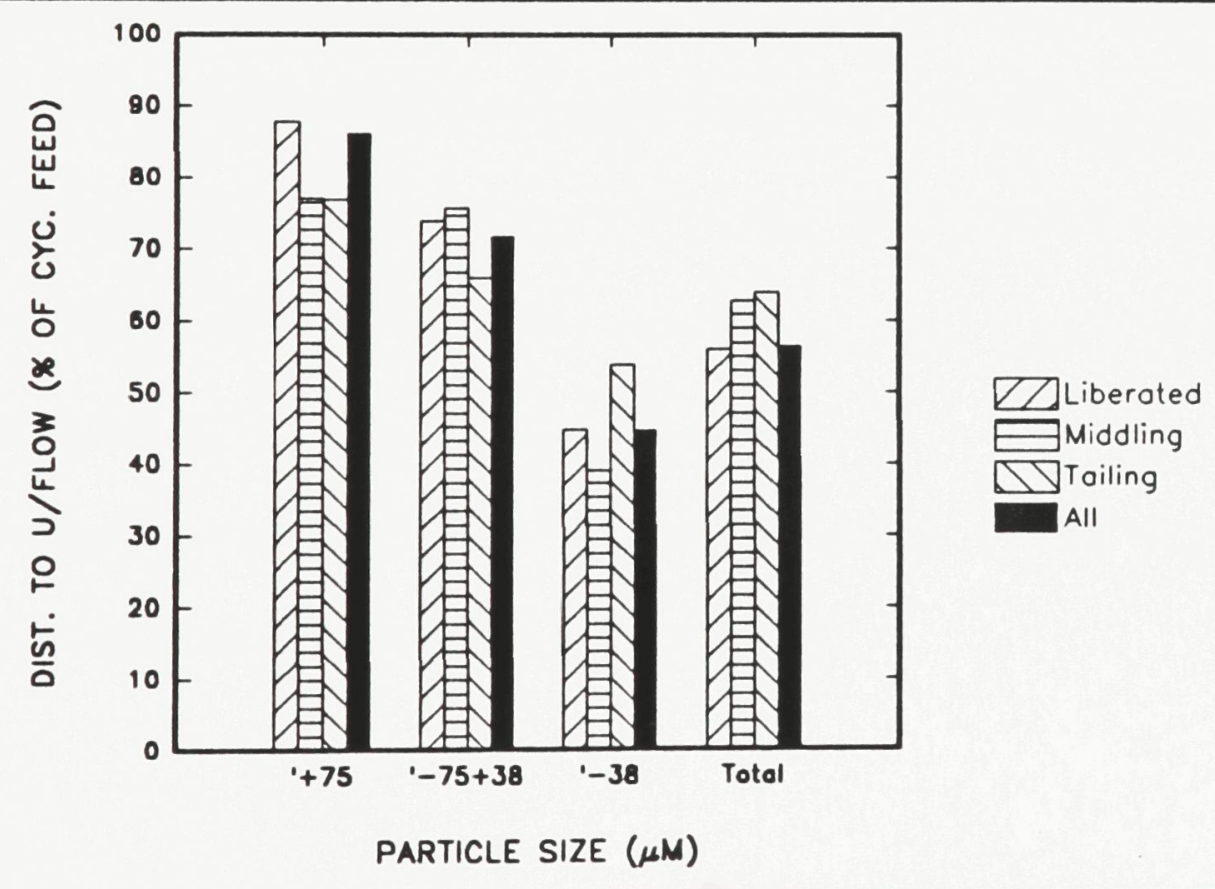

Figure 32 Sphalerite distribution by liberation class and size to Faro zinc regrind cyclone underflow. 


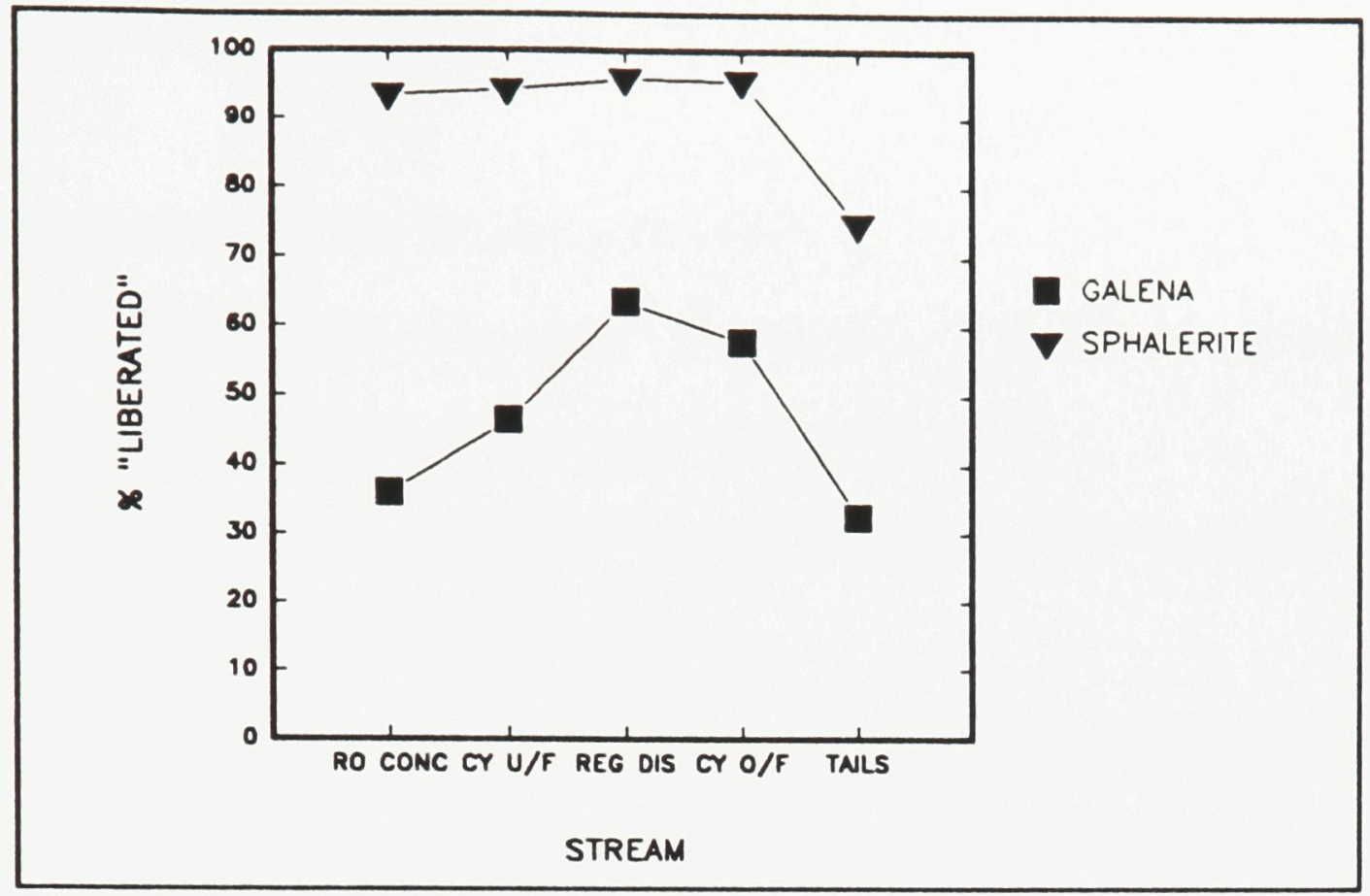

Figure 33 Percent "liberated" in selected streams of Faro zinc circuit.

Zinc cleaners

In the zinc first cleaners recovery of "liberated" sphalerite is $94 \%$ of the "liberated" sphalerite in the zinc first cleaner feed whereas recovery of unliberated sphalerite ( 0 $70 \%$ classes) is $89 \%$ (Figure 27). This shows poor rejection of unliberated sphalerite. The first cleaner tail consists of 5 TPH sphalerite of which $83 \%$ is "liberated" (Figure 30).

In the second cleaners "liberated" sphalerite recovery is $68 \%$ whereas locked sphalerite ( $0-70 \%$ classes) is $37 \%$ (Figure 27$)$.

In the third cleaners "liberated" sphalerite recovery is $55 \%$ whereas locked sphalerite ( $0-70 \%$ classes) recovery is $58 \%$ (Figure 27$)$.

Final tailings

In the final tailings $32 \%$ of the galena and $75 \%$ of the sphalerite is "liberated" 
(Figure 33).

In summary the data for galena show that:

1. Most of the galena recovered in the final lead concentrate was liberated class galena $(86 \%)$ and $97 \%$ of this was in particles less than $38 \mu \mathrm{m}$,

2. Only small amounts of galena recovered in the final lead concentrate were in middling (12\%) and tailing (2\%) class particles,

3. $78 \%$ of the galena lost to the lead scavenger tails was not "liberated", mostly in +75 and $-75+38 \mu \mathrm{m}$ particles. This indicates that the liberation of galena is not at optimum.

In summary the data for sphalerite show that:

1. Most of the sphalerite recovered in the final zinc concentrate was "liberated" sphalerite (95\%) and $84 \%$ of this was in particles less than $38 \mu \mathrm{m}$,

2. Only small amounts of sphalerite recovered in the final zinc concentrate were in middling ( $5 \%)$ and tailing $(<1 \%)$ class particles,

3. $69 \%$ of the sphalerite lost to the final lead concentrate was "liberated", mostly in $-38 \mu \mathrm{m}$ particles and $75 \%$ of the sphalerite lost to the final tailings was "liberated", mostly in $\mathbf{- 3 8} \mu \mathrm{m}$ particles. This indicates that sphalerite liberation is not a major factor in zinc losses. 
Mineral Associations of Sphalerite and Galena

Unbroken concentrator feed

The mineral associations of sphalerite and galena in the rod mill feed are measured in the same manner as in the core samples. The overall mineral associations of sphalerite and galena in the concentrator feed were estimated by combining the mineral associations in five samples of the rod mill feed with the associations measured in the core samples of $2 \mathrm{E}$ and $2 \mathrm{G}$ ore (Tables 10 and 12). The combined mineral associations are given in Table 20. The numbers in the table give the length of the grain boundary interface as a percentage of the total interface of galena and sphalerite with each mineral. The results show that most of the galena in the rod mill feed is associated with pyrite, barite, sphalerite and siderite. Most of the sphalerite is associated with pyrite, galena, quartz, siderite and barite.

TABLE 20

MINERAL ASSOCLATIONS IN ROD MILL FEED (\%PERIMETER)

\begin{tabular}{|c|c|c|c|c|c|c|c||}
\hline \multicolumn{7}{|c|}{ GALENA } \\
\hline QTZ & SID & PY & CP & BAR & PO & MUSC & SP \\
\hline 5 & 11 & 33 & 0 & 27 & 0 & 0 & 24 \\
\hline \multicolumn{7}{|c|}{ SPHALERTE } \\
\hline QTZ & SID & PY & CP & BAR & PO & MUSC & GAL \\
\hline 15 & 14 & 39 & 1 & 11 & 1 & 2 & 17 \\
\hline
\end{tabular}

\section{Preferred Breakage}

The mineral association-preferred breakage relationship developed in this thesis holds that during random breakage the perimeter associations must remain constant 
whereas during preferred breakage the perimeter associations must change. Assuming that the eleven selected polished sections of Faro ore are representative of the unbroken concentrator feed a comparison of the mineral associations of galena and sphalerite in those samples (Table 20) with that of the normalized mineral associations in the rod mill discharge (Table 21) shows significant differences and indicates breakage was not random. The sequence of the mineral association data for galena show a significant increase in the proportion of galena-siderite (INDEX $=1.18$ ) and galena-muscovite interface, and a significant decrease in galena-pyrite (INDEX $=-.3$ ) and galena-barite (INDEX $=-.56$ ) interface. This indicates strong bonding of galena to siderite and muscovite and weak bonding (preferential breakage) of galena to pyrite and barite. A moderate bonding of galena to sphalerite (INDEX $=-.21$ ) and to quartz $(\operatorname{INDEX}=.40)$ is also indicated. The sphalerite data show a significant increase in the proportion of sphalerite-siderite (INDEX $=.57)$, sphalerite-muscovite (INDEX $=3.0)$ and sphalerite-chalcopyrite (INDEX $=6.0$ ) interface and a significant decrease in sphalerite-pyrite (INDEX $=-.41$ ) interface. This indicates strong bonding of sphalerite to siderite, muscovite and chalcopyrite, weak bonding of sphalerite to pyrite. The bonding of sphalerite to galena, quartz and barite is moderate (INDICES $=-.06,-.27,-.09$, respectively).

In terms of fracture theory, the moderate to weak bonding behaviour of barite and pyrite to galena and sphalerite is interpreted as being due to their coarse grain size and to the relatively smooth intergranular surfaces of pyrite. Siderite, which is not finegrained, does exhibit a rough intergranular surface in unbroken ore. This suggests that moving fracture tips do not intersect the siderite grain surface easily. However, in broken 
ore the remaining intergranular surfaces of siderite appear to be smooth yet the mineral is still difficult to liberate by regrinding. As well barite also has rough intergranular surfaces in unbroken ore yet it breaks readily from galena. This suggests that mineral bonding is not only due to grain size and physical interlocking, but also to undetermined bonding forces.

Comparison of the associations in the rod mill discharge with that of the concentrator feed (Table 21) indicates that the preferential breakage noted above continues in the grinding circuit. Both siderite and sphalerite tend not to break away from galena

TABLE 21

NORMALIZED MINERAL ASSOCIATIONS IN ROD MILL DISCHARGE AND LEAD CIRCUIT FEED (\%PERIMETER)

\begin{tabular}{|c|c|c|c|c|c|c|c|c|}
\hline \multicolumn{9}{|c|}{ ROD MILL DISCHARGE } \\
\hline & \multicolumn{8}{|c|}{ GALENA } \\
\hline & QTZ & SID & PY & CP & BAR & PO & MUSC & SP \\
\hline & 7 & 24 & 23 & 2 & 12 & 3 & 10 & 19 \\
\hline INDEX & .40 & 1.18 & -.30 & na & -.56 & na & na &. .21 \\
\hline \multicolumn{9}{|c|}{ SPHALERITE } \\
\hline & QTZ & SID & PY & CP & BAR & PO & MUSC & GAL \\
\hline & 11 & 22 & 23 & 7 & 10 & 3 & 8 & 16 \\
\hline INDEX & -.27 & .57 & -.41 & 6.0 & -.09 & 2.0 & 3.0 &. .06 \\
\hline \multicolumn{9}{|c|}{ LEAD CIRCUIT FEED } \\
\hline & \multicolumn{8}{|c|}{ GALENA } \\
\hline & QTZ & SID & PY & CP & BAR & PO & MUSC & SP \\
\hline & 3 & 42 & 11 & 1 & 4 & 1 & 5 & 33 \\
\hline \multirow[t]{4}{*}{ INDEX } &. .4 & 2.82 & -.67 & na & -.85 & na & ma & .38 \\
\hline & \multicolumn{8}{|c|}{ SPHALERITE } \\
\hline & QTZ & SID & PY & CP & BAR & PO & MUSC & GAL \\
\hline & 2 & 39 & 18 & 5 & 6 & 1 & 4 & 23 \\
\hline INDEX & -.87 & 1.79 & -.54 & 4.0 & -.45 & 0 & 1.0 & .35 \\
\hline
\end{tabular}


but barite and pyrite do. Also siderite tends not to break from sphalerite but pyrite does. The consistency of these trends in all three samples confirms their validity. Strangely, the selective action of the hydrocyclones, which recirculates only the heaviest and coarsest particles in the Faro grinding circuit resulting in an apparent "preferential breakage", did not alter the association sequences as found in the rod mill but seemed to enhance the sequences. Perhaps siderite tends to bypass the mill due its relatively low specific gravity compared to barite and pyrite which tend to be reground. The suggested sequence of increasing bond strength of sphalerite with the major minerals is:

\section{PYRITE $\rightarrow$ BARITE $\rightarrow$ GALENA $\rightarrow$ SIDERITE}

Similarly, the sequence for galena is:

\section{BARITE $\rightarrow$ PYRITE $\rightarrow$ SPHALERITE $\rightarrow$ SIDERITE}

Concentrator samples

The mineral associations of sphalerite and galena in the concentrator samples were determined in two ways. For all the concentrator samples, the weight distribution of each ore mineral in various types of locked binary and ternary particles was measured. The balanced data are shown in Tables 22 and 23 for sphalerite and galena respectively. In those tables the distribution data for each sample consist of two lines. The upper line shows the distribution of the ore mineral among free particles, binary particles and ternary (i.e. contain three or more minerals) particles. Therefore the sum of the numbers in the upper line equals $100 \%$. The method of measuring the mineral associations in ternary particles involved measuring the area of the ore mineral of interest with every other 


\section{TABLE 22}

BALANCED DISTRIBUTION OF SPHALERITE NMONG BIMARY NMD TERMARY PARTICLES IN EACH STREAM OF FARO CONCENTRATOR (WTX)

LEAD CIRCUIT

Stream

Pb Ro Feed

Pb Ro Conc

Pb Ro Tail

$\mathrm{Pb} \mathrm{Sc}$ Conc

Pb Sc Tail

$\mathrm{Pb}$ CY U/F

Pb Regr Dis

$\mathrm{Pb}$ CYC O/F

$\mathrm{Pb}$ CL1 Conc

Pb CL1 Tail

$\mathrm{Pb} \mathrm{CL} 2$ Conc

Pb Cl2 Tail

Pb CL3 Tail

$\mathrm{Pb}$ CL3 Conc

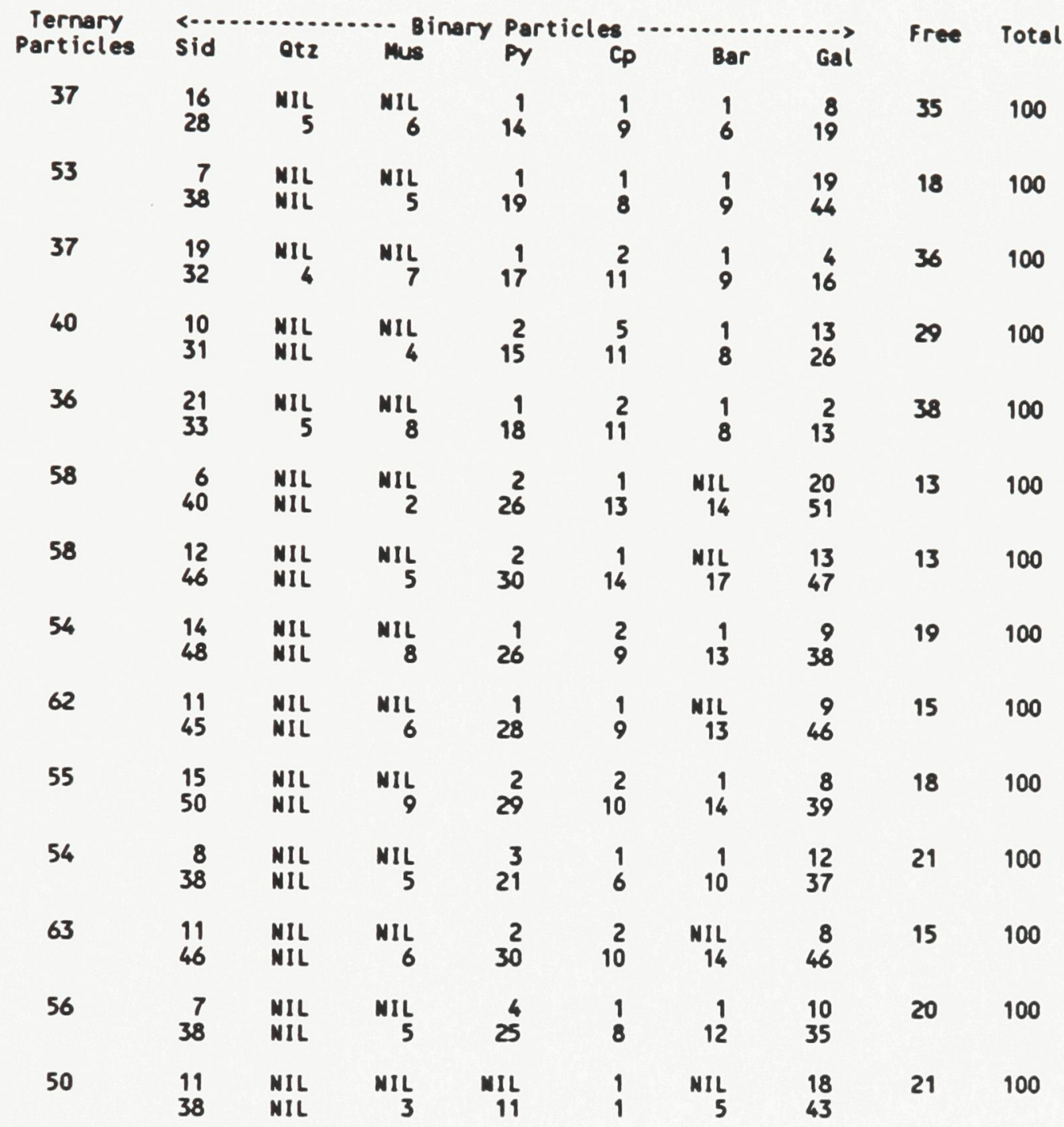
$100 \%$. 
TABLE 22 (CONTINUED)

ZINC CIRCUIT

\begin{tabular}{|c|c|c|c|c|c|c|c|c|c|c|}
\hline stream & $\begin{array}{l}\text { Ternary } \\
\text { Particles }\end{array}$ & sid & otz & $\begin{array}{l}\text { - Binary } \\
\text { Mus }\end{array}$ & $\begin{array}{l}\text { Par } \\
\text { Py }\end{array}$ & les. & Bar & Gal & Free & Total \\
\hline Pb Scar Tail & 31 & $\begin{array}{l}19 \\
22\end{array}$ & NIL & MIL & $\begin{array}{r}3 \\
16\end{array}$ & ? & NIL & $\begin{array}{l}2 \\
7\end{array}$ & 41 & 100 \\
\hline Zn Scar conc. & 41 & $\begin{array}{l}12 \\
32\end{array}$ & MIL & : & 22 & $\begin{array}{l}2 \\
8\end{array}$ & 1 & $\begin{array}{r}3 \\
18\end{array}$ & 38 & 100 \\
\hline Zn Ro feed & 32 & $\begin{array}{l}19 \\
23\end{array}$ & ${ }_{3}{ }_{3}$ & $:$ & $\begin{array}{c}3 \\
16\end{array}$ & $\begin{array}{l}2 \\
8\end{array}$ & NIL & $\begin{array}{l}2 \\
8\end{array}$ & 42 & 100 \\
\hline Zn Ro conc. & 29 & $\begin{array}{l}20 \\
21\end{array}$ & WIL & : & $\begin{array}{r}3 \\
16\end{array}$ & 2 & MIL & $\begin{array}{l}2 \\
6\end{array}$ & 43 & 100 \\
\hline Zn Ro Tail & 55 & $\begin{array}{l}14 \\
36\end{array}$ & MIL & $:$ & $\begin{array}{r}2 \\
19\end{array}$ & $\begin{array}{l}3 \\
7\end{array}$ & ${ }_{10}^{2}$ & 21 & 22 & 100 \\
\hline Zn Scav Tail & 73 & $\begin{array}{l}1 \\
47\end{array}$ & $\begin{array}{l}1 \\
7\end{array}$ & : & 32 & $\begin{array}{l}2 \\
4\end{array}$ & MIL & $\begin{array}{r}1 \\
30\end{array}$ & 18 & 100 \\
\hline Zn Regr. Disch & 13 & $\begin{array}{l}4 \\
5\end{array}$ & $\begin{array}{l}\text { NIL } \\
\text { WIL }\end{array}$ & $:$ & $\begin{array}{l}1 \\
3\end{array}$ & $\begin{array}{l}9 \\
6\end{array}$ & $\begin{array}{l}\text { MIL } \\
\text { MIL }\end{array}$ & $\begin{array}{l}3 \\
6\end{array}$ & 70 & 100 \\
\hline Zn CrC U/F & 23 & $\begin{array}{l}14 \\
15\end{array}$ & MIL & $:$ & ${ }_{10}^{2}$ & $\begin{array}{l}5 \\
8\end{array}$ & NIL & 2 & 53 & 100 \\
\hline Zn CrC O/F & 17 & $\begin{array}{l}7 \\
8\end{array}$ & MIL & $:$ & $\begin{array}{l}1 \\
6\end{array}$ & $\begin{array}{l}7 \\
6\end{array}$ & $\frac{\text { WIL }}{2}$ & $\begin{array}{l}3 \\
4\end{array}$ & 64 & 100 \\
\hline Zn CL2 Tail & 38 & $\begin{array}{l}20 \\
32\end{array}$ & MIL & : & $\begin{array}{r}3 \\
12\end{array}$ & 19 & $\begin{array}{l}1 \\
7\end{array}$ & $\begin{array}{r}6 \\
22\end{array}$ & 32 & 100 \\
\hline Zn CL1 Cone & 26 & $\begin{array}{l}13 \\
19\end{array}$ & MIL & $:$ & $\begin{array}{l}2 \\
8\end{array}$ & $\begin{array}{l}5 \\
9\end{array}$ & NIL & 12 & 50 & 100 \\
\hline Zn CL1 Tail & 38 & $\begin{array}{l}10 \\
25\end{array}$ & NIL & : & ${ }_{17}^{2}$ & $\begin{array}{l}1 \\
7\end{array}$ & $\begin{array}{l}1 \\
7\end{array}$ & $\begin{array}{l}10 \\
21\end{array}$ & 38 & 100 \\
\hline In CL2 Conc. & 18 & $\begin{array}{r}9 \\
11\end{array}$ & MIL & - & $\begin{array}{l}2 \\
6\end{array}$ & $\begin{array}{l}7 \\
7\end{array}$ & $\frac{\text { NIL }}{2}$ & 4 & 60 & 100 \\
\hline Zn CL 3 Tail & 22 & $\begin{array}{l}12 \\
16\end{array}$ & NIL & : & $\begin{array}{l}2 \\
7\end{array}$ & $\begin{array}{l}5 \\
8\end{array}$ & $\begin{array}{l}1 \\
3\end{array}$ & $\begin{array}{r}6 \\
13\end{array}$ & 51 & 100 \\
\hline Zn CL3 conc. & 14 & $\begin{array}{l}7 \\
6\end{array}$ & $\begin{array}{l}\text { MIL } \\
\text { WIL }\end{array}$ & 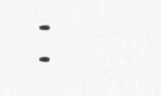 & $\begin{array}{l}1 \\
5\end{array}$ & $\begin{array}{l}8 \\
6\end{array}$ & NIL & $\begin{array}{l}2 \\
2\end{array}$ & 68 & 100 \\
\hline Zn final Tail & 46 & $\begin{array}{r}8 \\
31\end{array}$ & $\begin{array}{l}\text { NIL } \\
6\end{array}$ & : & 21 & $\begin{array}{l}1 \\
6\end{array}$ & $\begin{array}{l}1 \\
9\end{array}$ & $\begin{array}{r}8 \\
23\end{array}$ & 33 & 100 \\
\hline
\end{tabular}

- Includes muscovite except for Pb Scav tail 
TABLE 23

BALANCED DISTRIBUTION OF GALEMA NHONG BIMARY NND TERMARY PARTICLES

IN EACH STREAM OF FARO CONCENTRATOR(NTX)

LEND CIRCUIT

\begin{tabular}{|c|c|c|c|c|c|c|c|c|c|c|}
\hline stream & $\begin{array}{c}\text { Ternary } \\
\text { Particles }\end{array}$ & sid & Qtz & Mus & $\begin{array}{l}\text { Par } \\
\text { Py }\end{array}$ & les & Bar & sp & Free & Total \\
\hline Pb Ro Feed & 40 & 18 & $\begin{array}{r}\text { NIL } \\
1\end{array}$ & NIL & $\begin{array}{l}2 \\
8\end{array}$ & NIL & $\begin{array}{l}1 \\
3\end{array}$ & $\begin{array}{r}7 \\
12\end{array}$ & 46 & 100 \\
\hline Pb Ro Conc. & 40 & $\begin{array}{r}6 \\
18\end{array}$ & NIL & NIL & $\begin{array}{l}2 \\
9\end{array}$ & NIL & $\begin{array}{l}1 \\
4\end{array}$ & $\stackrel{8}{14}$ & 44 & 100 \\
\hline Pb Ro Tail & 61 & $\begin{array}{r}8 \\
50\end{array}$ & NIL & $\begin{array}{r}\text { NIL } \\
4\end{array}$ & $\begin{array}{r}5 \\
27\end{array}$ & $\begin{array}{r}\text { NIL } \\
2\end{array}$ & 13 & 29 & 17 & 100 \\
\hline Pb Sc Conc. & 48 & $\begin{array}{r}9 \\
35\end{array}$ & NIL & $\begin{array}{r}\text { NIL } \\
3\end{array}$ & $\frac{6}{17}$ & $\begin{array}{r}\text { NIL } \\
2\end{array}$ & $\begin{array}{r}\text { NIL } \\
9\end{array}$ & $\begin{array}{l}11 \\
23\end{array}$ & 31 & 100 \\
\hline Pb Sc. Tail & 72 & 6 & NIL & $\begin{array}{r}\text { NIL } \\
5\end{array}$ & $\begin{array}{r}5 \\
36\end{array}$ & $\begin{array}{r}\text { NIL } \\
2\end{array}$ & $\begin{array}{r}1 \\
17\end{array}$ & 34 & 12 & 100 \\
\hline $\mathrm{Pb}$ CY U/F & 36 & $\begin{array}{r}5 \\
25\end{array}$ & $\begin{array}{l}\text { NIL } \\
\text { NIL }\end{array}$ & NIL & $\begin{array}{r}3 \\
12\end{array}$ & $\begin{array}{r}\text { NIL } \\
2\end{array}$ & $\begin{array}{l}1 \\
7\end{array}$ & 15 & 51 & 100 \\
\hline Pb Regr. Disch & 38 & $\begin{array}{r}5 \\
27\end{array}$ & $\begin{array}{l}\text { NIL } \\
\text { NIL }\end{array}$ & NIL & $\begin{array}{r}3 \\
12\end{array}$ & NIL & $\begin{array}{r}\text { NIL } \\
8\end{array}$ & $\begin{array}{r}3 \\
16\end{array}$ & 51 & 100 \\
\hline $\mathrm{Pb}$ CrC O/F & 45 & $\frac{6}{25}$ & $\begin{array}{l}\text { NIL } \\
\text { NIL }\end{array}$ & ${ }_{3}^{N I L}$ & $10^{1}$ & NIL & $\begin{array}{r}\text { NIL } \\
6\end{array}$ & 15 & 44 & 100 \\
\hline $\mathrm{Pb}$ CL1 Conc & 41 & $\begin{array}{r}9 \\
18\end{array}$ & $\begin{array}{l}\text { NIL } \\
\text { NIL }\end{array}$ & $\begin{array}{r}\text { NIL } \\
2\end{array}$ & $\begin{array}{l}1 \\
7\end{array}$ & NIL & $\begin{array}{r}\text { NIL } \\
4\end{array}$ & $\begin{array}{r}3 \\
15\end{array}$ & 45 & 100 \\
\hline Pb CL1 Tail & 61 & $\begin{array}{l}14 \\
49\end{array}$ & $\begin{array}{r}\text { NIL } \\
2\end{array}$ & $\begin{array}{r}\text { NIL } \\
7\end{array}$ & $\begin{array}{r}4 \\
35\end{array}$ & ${ }_{3}^{\text {NIL }}$ & 20 & $\begin{array}{r}6 \\
35\end{array}$ & 14 & 100 \\
\hline Pb CL2 Conc & 37 & $\begin{array}{r}9 \\
17\end{array}$ & $\begin{array}{l}\text { NIL } \\
\text { NIL }\end{array}$ & NIL & $\begin{array}{l}1 \\
5\end{array}$ & NIL & ${ }_{3}^{\text {NIL }}$ & $\begin{array}{r}5 \\
11\end{array}$ & 47 & 100 \\
\hline Pb CL2 Tail & 42 & $\begin{array}{l}17 \\
18\end{array}$ & $\begin{array}{r}\text { NIL } \\
1\end{array}$ & $\underset{4}{\text { NIL }}$ & 13 & NIL & $\begin{array}{r}\text { NIL } \\
7\end{array}$ & $\begin{array}{r}3 \\
23\end{array}$ & 35 & 100 \\
\hline Pb CL 3 Tail & 31 & $\begin{array}{l}21 \\
15\end{array}$ & $\begin{array}{l}\text { NIL } \\
\text { NIL }\end{array}$ & $\begin{array}{r}\text { NIL } \\
1\end{array}$ & $\begin{array}{l}2 \\
8\end{array}$ & NIL & $\begin{array}{r}\text { NIL } \\
4\end{array}$ & $\begin{array}{r}9 \\
15\end{array}$ & 51 & 100 \\
\hline $\mathrm{Pb}$ CL 3 Conc & 40 & $\begin{array}{r}3 \\
21\end{array}$ & $\begin{array}{l}\text { NIL } \\
\text { NIL }\end{array}$ & ${ }_{2}^{\text {NIL }}$ & $\begin{array}{l}1 \\
3\end{array}$ & $\begin{array}{l}\text { NIL } \\
\text { NIL }\end{array}$ & $\begin{array}{r}\text { NIL } \\
2\end{array}$ & $\begin{array}{r}4 \\
11\end{array}$ & 52 & 100 \\
\hline
\end{tabular}

- The distribution of the ternaries, given in the second line for each stream, does not sum to $100 \%$. 
TABLE 23 (CONTINUED)

ZINC CIRCUIT

\begin{tabular}{|c|c|c|c|c|c|c|c|c|c|c|}
\hline Strean & $\begin{array}{l}\text { Ternary } \\
\text { Particles }\end{array}$ & siof & otz & $\because 8 i$ & $\begin{array}{l}\text { ry Par } \\
\text { Py }\end{array}$ & ${ }_{\text {CP }}$ & Bar & sp & Free & Total \\
\hline Pb Scav Tail & 68 & $\begin{array}{r}8 \\
56\end{array}$ & MIL & MIL & 27 & $\frac{\mathrm{NIL}}{2}$ & $\begin{array}{c}1 \\
15\end{array}$ & $\begin{array}{r}3 \\
30\end{array}$ & 18 & 100 \\
\hline Zn Scav Conc. & 63 & 44 & WIL & $:$ & $\begin{array}{r}3 \\
35\end{array}$ & NIL & ${ }_{20}^{\text {MIL }}$ & 37 & 24 & 100 \\
\hline Zn Ro feed & 67 & $\begin{array}{r}7 \\
54\end{array}$ & NIL & : & 28 & ${ }_{3}^{\text {NIL }}$ & $\begin{array}{r}1 \\
15\end{array}$ & 31 & 19 & 100 \\
\hline Zn Ro Conc. & 67 & $\begin{array}{r}7 \\
54\end{array}$ & $\begin{array}{r}\text { MIL } \\
2\end{array}$ & 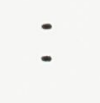 & 21 & MIL & $\begin{array}{r}1 \\
15\end{array}$ & $\begin{array}{r}5 \\
35\end{array}$ & 17 & 100 \\
\hline Zn Ro Tail & 67 & $\begin{array}{r}7 \\
54\end{array}$ & 11 & : & 33 & $\begin{array}{r}\text { MIL } \\
2\end{array}$ & $\begin{array}{r}1 \\
16\end{array}$ & $\begin{array}{r}2 \\
28\end{array}$ & 20 & 100 \\
\hline Zn Scav Tail & 68 & $\begin{array}{r}9 \\
58\end{array}$ & $\begin{array}{r}1 \\
12\end{array}$ & $\therefore$ & $\begin{array}{r}1 \\
32\end{array}$ & MIL & ${ }_{14}^{2}$ & $\underset{24}{\text { NIL }}$ & 19 & 100 \\
\hline Zn Regr. Disch & 27 & MIL & NIL & : & $\underset{10}{\text { MIL }}$ & $\mathrm{MIL}_{4}$ & $\begin{array}{l}1 \\
5\end{array}$ & $\begin{array}{l}17 \\
23\end{array}$ & 55 & 100 \\
\hline Zn CYC U/F & 52 & $\begin{array}{r}2 \\
38\end{array}$ & MIL & : & $\begin{array}{r}2 \\
18\end{array}$ & ${ }_{3}^{\text {MIL }}$ & $\begin{array}{r}1 \\
12\end{array}$ & $\begin{array}{l}10 \\
35\end{array}$ & 33 & 100 \\
\hline Zn CrC O/F & 29 & $\begin{array}{r}4 \\
18\end{array}$ & MIL & : & $\begin{array}{l}1 \\
9\end{array}$ & $\underset{5}{\text { MIL }}$ & MIL & $\begin{array}{l}16 \\
17\end{array}$ & 49 & 100 \\
\hline Zn CL2 Tail & 45 & $\begin{array}{r}8 \\
36\end{array}$ & NIL & : & $\begin{array}{r}1 \\
17\end{array}$ & NIL & ${ }_{11}^{2}$ & $\begin{array}{l}10 \\
33\end{array}$ & 34 & 100 \\
\hline Zn CL1 Conc & 40 & $\begin{array}{r}6 \\
32\end{array}$ & NIL & : & $\begin{array}{r}1 \\
15\end{array}$ & MIL & ${ }_{10}^{2}$ & $\begin{array}{l}12 \\
31\end{array}$ & 39 & 100 \\
\hline Zn CL1 Tail & 39 & $\begin{array}{l}10 \\
33\end{array}$ & MIL & $:$ & $\begin{array}{r}3 \\
18\end{array}$ & ${ }_{4}^{\text {NIL }}$ & MIL & $\begin{array}{r}8 \\
20\end{array}$ & 41 & 100 \\
\hline In CL2 conc. & 33 & 19 & NIL & $:$ & $\begin{array}{l}1 \\
7\end{array}$ & NIL & 11 & $\begin{array}{l}23 \\
23\end{array}$ & 40 & 100 \\
\hline Zn CL 3 Tail & 38 & 24 & MIL & $:$ & $\begin{array}{l}1 \\
9\end{array}$ & ${ }_{4}^{\text {NIL }}$ & $\begin{array}{r}1 \\
12\end{array}$ & $\begin{array}{l}24 \\
26\end{array}$ & 33 & 100 \\
\hline Zn CL3 conc. & 23 & $\begin{array}{l}1 \\
8\end{array}$ & $\begin{array}{l}\text { NIL } \\
\text { NIL }\end{array}$ & : & ${ }_{3}^{\text {NIL }}$ & $\underset{6}{\text { NIL }}$ & $\begin{array}{r}\text { NIL } \\
6\end{array}$ & $\begin{array}{l}21 \\
15\end{array}$ & 56 & 100 \\
\hline Zn Final Tail & 60 & $\begin{array}{l}10 \\
50\end{array}$ & $\begin{array}{r}1 \\
12\end{array}$ & : & $\begin{array}{c}1 \\
28\end{array}$ & $\begin{array}{r}\text { NIL } \\
2\end{array}$ & $\begin{array}{r}1 \\
11\end{array}$ & 23 & 25 & 100 \\
\hline
\end{tabular}

- Includes muscovite except for Pb Scav tail 
mineral in all particles. Since each ternary particle contains two or more other minerals, the ore mineral is measured at least twice in measuring the association. Hence the total for the ore mineral in the second line is considerably higher than the value for the ternary particle in the first line. Nevertheless, the sum of the associations (columnwise) is an exact measure of the proportion the ore mineral which is associated with a specific nonore mineral.

The technique of measuring associations by intergranular contact was also performed on the flotation concentrator final concentrates and tailings. The data are shown in Appendix 12. The normalized perimeter data for the lead conc., zinc conc. and the final tailings are shown in Table 24. The data in the table show that in the lead concentrate galena is most strongly associated with sphalerite and siderite. This shows that much of the galena reporting to the lead concentrate is attached to sphalerite and siderite. In the zinc concentrate the sphalerite grains are mostly attached to siderite. Also most of the locked galena in the zinc concentrate is locked to sphalerite indicating that some of the galena is pulled into the zinc concentrate by locking with sphalerite. Both sphalerite and galena lost to the final tailings are mostly locked with siderite. Thus the perimeter technique highlights the deleterious effect the associations of sphalerite and galena with siderite and sphalerite and galena with each other in the unbroken ore has on the grade and recovery of lead and zinc.

The perimeter association technique also gives an alternate measurement of mineral liberation, as the percentage of mineral perimeter which is exposed or free. An examination of the relative changes in the percentage of free with sieve size in the lead 
TABLE 24

NORMALIZED MINERAL ASSOCIATIONS IN FARO CONCENTRATOR PRODUCTS (\%PERIMETER)

\begin{tabular}{|c|c|c|c|c|c|c|c|}
\hline \multicolumn{8}{|c|}{ FINAL LEAD CONCENTRATE } \\
\hline \multicolumn{8}{|c|}{ OALENA } \\
\hline QTZ & SID & PY & $\mathbf{C P}$ & BAR & PO & MUSC & SP \\
\hline 3 & 35 & 14 & 3 & 2 & 4 & 1 & 38 \\
\hline \multicolumn{8}{|c|}{ SPHALERTE } \\
\hline QTZ & SID & PY & $\mathbf{C P}$ & BAR & PO & MUSC & GAL \\
\hline 0.22 & 14.16 & 7.24 & 3.35 & 0.00 & 3.46 & 0.22 & 71.35 \\
\hline \multicolumn{8}{|c|}{ FINAL ZINC CONCENTRATE } \\
\hline \multicolumn{8}{|c|}{ GALENA } \\
\hline QTZ & SID & PY & $\mathbf{C P}$ & BAR & PO & MUSC & SP \\
\hline 3.03 & 3.21 & 7.41 & 2.35 & 0.49 & 2.10 & 0.06 & 81.35 \\
\hline \multicolumn{8}{|c|}{ SPHALERTTE } \\
\hline QTZ & SID & PY & $\mathbf{C P}$ & BAR & PO & MUSC & GAL \\
\hline 0.66 & 36.43 & 21.85 & 10.60 & 1.32 & 11.26 & 0.66 & 17.22 \\
\hline \multicolumn{8}{|c|}{ FINAL TAIIINGS } \\
\hline \multicolumn{8}{|c|}{ GALENA } \\
\hline QTZ & SID & PY & $\mathrm{CP}$ & BAR & PO & MUSC & SP \\
\hline 6.51 & 51.01 & 19.92 & 0.98 & 5.41 & 2.10 & 1.12 & 12.95 \\
\hline \multicolumn{8}{|c|}{ SPHALERITE } \\
\hline QTZ & SID & PY & CP & BAR & PO & MUSC & GAL \\
\hline 6.28 & 43.89 & 25.93 & 1.22 & 4.05 & 4.59 & 1.89 & 12.15 \\
\hline
\end{tabular}

circuit feed for sphalerite and galena shows that at the grind achieved in the feed the percentage of free sphalerite does not change and therefore it is close to its optimum grind (Appendix 12). On the contrary, the percentage of free galena changes from about $10 \%$ in the $+75 \mu \mathrm{m}$ fraction to about $4 \%$ in the $-75 \mu \mathrm{m}$ fractions indicating that galena is not close to its optimum grind. 
A comparison of the variations between streams of percentage free on a weight $\%$ basis versus a perimeter \% basis show that there is general agreement in the trends (Figure 34). However, there are large differences which reflect the fact that a significant percentage of exposed perimeter exists in locked particles. The variations in these differences provide useful information on mineral behaviour. It is most significant that the differences are largest for sphalerite in the lead concentrate. This indicates that a considerable amount of locked sphalerite with large areas of exposed surface is being lost to the lead concentrate. The data for galena do not show such a large variation. It is also noteworthy that the percent exposed perimeter is very high for sphalerite $(91 \%)$ in the lead concentrate and for galena $(84 \%)$ in the zinc concentrate.

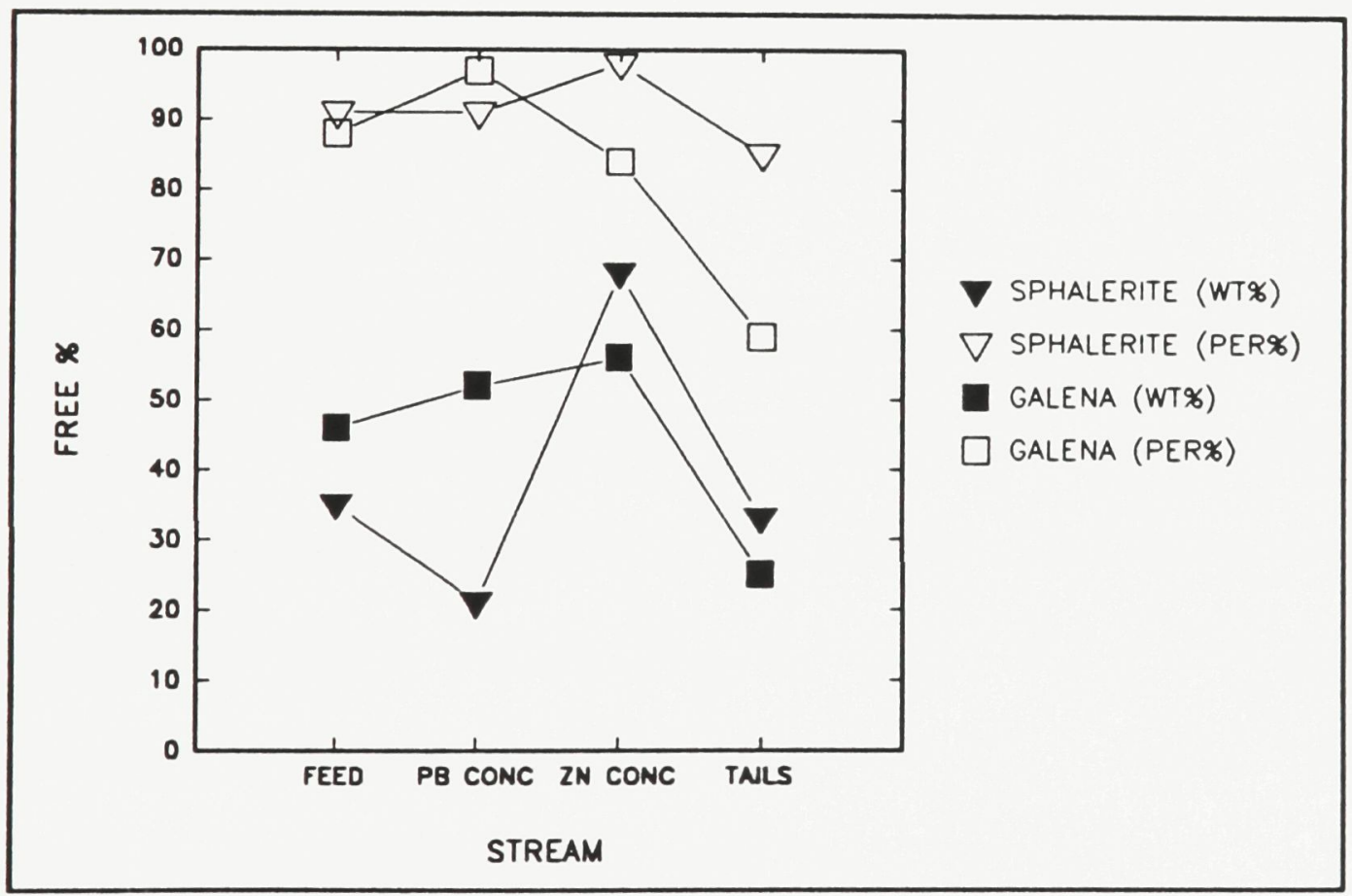

Figure 34 Comparison of percent free by wt\% versus perimeter\% of sphalerite and galena in selected streams of Faro concentrator. 


\section{Distribution of binary particles}

The influence on the recovery of sphalerite and galena by locking with each of the other gangue minerals was evaluated by determining the distribution of the minerals locked in binary particles $(0-90 \%$ class $)$ to the concentrates. If all the gangue minerals have an identical flotation response then the distributions of the binaries should be identical. The data in Table 25 show that the distributions are not identical. For the lead circuit, the data show that the chances of a binary galena particle being recovered is improved by locking with sphalerite $(88 \%)$, followed by siderite, pyrite and barite. Of course, the distribution of sphalerite to the lead concentrate is also increased by locking with galena only. For the zinc circuit galena distribution to the zinc concentrate is increased by locking with sphalerite. The recovery of sphalerite in binary particles is improved by locking with chalcopyrite $(98 \%)$, followed by siderite, and pyrite.

\section{Encapsulated ore minerals}

The quantities of ore minerals which are completely locked (i.e. not having any free perimeter) in the various gangue minerals in the final concentrator tailings were measured. The efficiency of differential flotation is related to the amount of exposed ore mineral surface. The quantity of encapsulated ore minerals should indicate the reasons, if any, for losses to the tailings by encapsulation. The data in Table 26 show that encapsulation is not a significant factor in metal losses to the tailings. 
TABLE 25

FLONRATES AND OISTRIBUTIONS TO CONCENTRATES OF GALEMA AND SPHALERITE LOCKED IN BIMARY PARTICLES

FARO LEAD FLOTATION CIRQUIT

Galene Flowrates (tph)

Lead Conc. Lead Tails.

$\begin{array}{lll}0.68 & 0.27 & 72 \\ 0.00 & 0.00 & -5 \\ 0.23 & 0.22 & 51 \\ 0.00 & 0.00 & - \\ 0.00 & 0.04 & 0 \\ 0.91 & 0.13 & 88\end{array}$

Sphalerite Flowrates (tph)

Type of binary

Sp-siderite

Sp-Quartz

Sp-Pyrite

Sp-Chal copyrite

Sp-Bari te

Sp-Galena

Gol-Siderite

Gal-Pyrite

Gal-Chal copyrite

Gal-Barite

Gal-Sphalerite

Lead Conc.

0.54

0.00

0.00

0.05

0.00

0.89

Lead Tails

10.20

0.00

0.49

0.97

0.49

0.97

Sphalerite Distribution(x)
5
o
5
48

FARO ZINC FLOTATION CIRCUIT
Galene Flowrates (tph)

zinc Conc.

0.01

0.00

0.00

0.00

0.00

0.15

Sphalerite Flowrates (tph)

zinc Conc.

2.67
0.00
0.38
3.05
0.00
0.76
Zinc Tails.

\subsection{2}

0.00

0.13

0.06

0.06

0.52
Galena Distribution ( $(x)$

zinc conc.
4
0
0
83

Sp-Barite

Sp-Galene
Lead Conc.

Galena Distribution ( $x$ )

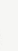

(2)

8


TABLE 26

DISTRIBUTION OF SPHALERTTE AND GALENA IN FREE, EXPOSED AND
ENCAPSULATED GRAINS IN FARO FINAL TAIINOS (WT\%)

\begin{tabular}{|c|c|c|c|}
\hline MINERAL & FREE & $\begin{array}{c}\text { EXP. } \\
\text { OSED }\end{array}$ & $\begin{array}{c}\text { ENCAP } \\
\text { SULAT } \\
\text { ED }\end{array}$ \\
\hline \multicolumn{4}{|c|}{$+75 \mu \mathrm{M}$} \\
\hline SPHALERTTE & 20 & 80 & 0 \\
\hline GALENA & 12 & 69 & 19 \\
\hline \multicolumn{5}{|c|}{$+38 \mu \mathrm{M}$} \\
\hline SPHALERTTE & 30 & 66 & 4 \\
\hline GALENA & 22 & 73 & 5 \\
\hline \multicolumn{5}{|c|}{$-38 \mu \mathrm{M}$} \\
\hline SPHALERTTE & 36 & 64 & 0 \\
\hline GALENA & 35 & 65 & 0 \\
\hline \multicolumn{5}{|c|}{ OVERALL } \\
\hline SPHALERTTE & 33 & 66 & 1 \\
\hline GALENA & 25 & 67 & 8 \\
\hline
\end{tabular}

Mineral associations of gangue minerals in the final lead and zinc concentrates

The associations of the gangue minerals reporting to the lead and zinc concentrates were determined by measuring the distribution of these minerals locked in particles which contain either sphalerite or galena, both sphalerite and galena or neither of the two ore minerals. The data in Table 27 show what proportion of these minerals are reporting to the concentrates due to locking with sphalerite or galena.

Associations of sphalerite and galena in the lead flotation circuit

By far the largest portion (70\%) of the galena lost to the scavenger tails is associated with siderite (Table 23). The galena is also associated with pyrite (41\%) and 
TABLE 27

DISTRIBUTION OF DILUENT MINERALS IN FARO CONCENTRATES (WT\% OF CONCENTRATE)

\begin{tabular}{|c|c|c|c|c|}
\hline \multicolumn{5}{|c|}{ LEAD CONCENTRATE } \\
\hline MINERAL & $\begin{array}{c}\text { Locked with } \\
\text { galena but } \\
\text { not } \\
\text { sphalerite }\end{array}$ & $\begin{array}{l}\text { Locked with } \\
\text { sphalerite } \\
\text { but not } \\
\text { galena }\end{array}$ & $\begin{array}{l}\text { Locked with } \\
\text { both }\end{array}$ & $\begin{array}{l}\text { Locked with } \\
\text { nei ther }\end{array}$ \\
\hline Quartz & 0.19 & 0.13 & 0.01 & 0.60 \\
\hline Muscovite & 0.19 & 0.05 & 0.03 & 0.87 \\
\hline Pyrite & 1.55 & 0.56 & 0.15 & 1.83 \\
\hline Chal copyrite & 0.00 & 0.07 & 0.00 & 0.05 \\
\hline Barite & 0.58 & 0.00 & 0.17 & 1.32 \\
\hline Pyrrhotite & 0.01 & 0.02 & 0.00 & 0.17 \\
\hline Sphalerite & 7.95 & $2.74^{\circ}$ & $\ldots$ & 2.35 \\
\hline siderite & 1.19 & 1.54 & 0.29 & 3.47 \\
\hline \multicolumn{5}{|c|}{ ZINC CONCENTRATE } \\
\hline Quartz & 0.01 & 0.16 & 0.00 & 0.12 \\
\hline Pyrite & 0.02 & 0.37 & 0.05 & 0.36 \\
\hline Chal copyrite & 0.00 & 0.45 & 0.03 & 0.17 \\
\hline Barite & 0.00 & 0.07 & 0.02 & 0.19 \\
\hline Pyrrhotite & 0.01 & 0.06 & 0.02 & 0.16 \\
\hline Galena & $1.15^{\circ}$ & 0.56 & $\ldots$ & 0.35 \\
\hline siderite & 0.08 & 1.20 & 0.17 & 0.90 \\
\hline
\end{tabular}

- Free sphalerite
- Free galena

sphalerite $(37 \%)$. The largest portion of galena recovered in the rougher concentrate is locked with siderite $(24 \%)$ and secondly with sphalerite $(22 \%)$. A large portion of the sphalerite $(63 \%)$ distributed to the lead rougher concentrate is locked in particles that contain galena (Table 22). Table 23 shows that most of the galena in the regrind mill is attached to siderite. Almost $60 \%$ of the sphalerite in the mill discharge is associated with siderite and galena (Table 22). 
In all the streams of the lead cleaner circuit Table 23 shows that galena is mostly locked with siderite. In the final lead concentrate galena is mostly attached to siderite (24\%) and sphalerite (15\%). Data in Table 25 show that galena locked in binary particles with sphalerite and siderite are preferentially recovered in the final lead concentrate. This indicates that sphalerite is not depressed as well as pyrite in the lead circuit. According to data in Table 22 approximately $40 \%$ of the sphalerite in the lead concentrate is not associated with galena and approximately $20 \%$ of the sphalerite is free and $11 \%$ is attached to siderite as binary particles. Furthermore, $82 \%$ of the siderite in the lead concentrate is not locked with galena and $53 \%$ is not locked with either galena or sphalerite (Table 27). The association data show that dilution of the lead concentrate by gangue minerals is not mainly due to locking. The recovery of sphalerite, siderite and pyrite which are not locked with galena indicates this. Activation of these minerals is probably occurring.

Associations of sphalerite and galena in the zinc flotation circuit

Table 22 shows that $41 \%$ of the sphalerite in the zinc rougher concentrate is locked with siderite and $39 \%$ of the sphalerite lost to tailings is locked with siderite. Most of the galena distributed to the rougher zinc concentrate is locked with siderite $(61 \%)$ and sphalerite (40\%) (Table 23).

The regrind mill increases sphalerite liberation by a small amount while galena liberation is increased by a large amount due to the fact that the feed to the regrind mill contains a large amount of sphalerite with a small amount of galena locked with it. Table 
23 shows that $45 \%$ of the galena in the regrind mill feed (zinc cyc. $w / f$ ) is locked with sphalerite.

The sphalerite in the first cleaner concentrate is mostly locked with siderite $(32 \%)$ (Table 22). In the second cleaner sphalerite is mostly locked with siderite but now chalcopyrite is a close second showing that sphalerite locked with siderite is being rejected in favour of sphalerite locked with chalcopyrite. The locked sphalerite $(0$ $99.99 \%$ classes) in the final zinc concentrate is mostly attached to chalcopyrite and siderite (Table 22). The amount of siderite in the zinc concentrate is $2 \%$ whereas that of chalcopyrite is $.65 \%$ (Table 27). Most of the galena (56\%) in the final zinc concentrate is free (Table 23).

In the final tailings most of the galena (60\%) is associated with siderite. Table 26 shows that only $8 \%$ of the galena is encapsulated. A large portion of the sphalerite is locked with siderite $(39 \%)$ and galena (31\%). Table 26 shows that only $1 \%$ of the sphalerite in the final tails is encapsulated.

Relationship between Base Metal Recovery and Grade and Mineralogy in Faro Ore

In general, metal recovery and grade are adversely affected by a combination of inadequate mineral liberation, surface activation or depression of minerals and mechanical entrainment. These factors result in portions of the ore minerals being misplaced in the wrong concentrate and in the final tailings. Of the three factors, only mineral liberation was determined. The determination of the relative importance of activation/depression versus mechanical entrainment in the ore is beyond the scope of this study. The fact that 
activation is occurring may only be surmised by the presence, or absence, of known deleterious minerals.

Lead recovery and grade

Overall, the concentrator recovers $83 \%$ of the lead at a grade of $62 \%$ (Appendix 10). The galena in the lead concentrate is mostly "liberated" $(86 \%)$ and in the $-38 \mu \mathrm{m}$ sieve fraction (96\%). Lead reporting to the zinc circuit represents $17 \%$ of the lead in the feed. This amount is distributed as $13 \%$ to the tailings and $4 \%$ to the zinc concentrate.

The galena in the lead scavenger tails is predominantly (78\%) locked in middlings and tailings particles. Most of this galena is in the $+38 \mu \mathrm{m}$ sieve fraction, only $22 \%$ is "liberated" and $12 \%$ is free. The liberation of the galena in the final tailings has increased due to the zinc regrind to $32 \%$ "liberated" and $25 \%$ free. Galena in the unbroken ore is very fine-grained; about $27 \%$ of it is finer than $13 \mu \mathrm{m}$. The actual grind achieved in the feed to the lead cleaner circuit is $79 \%-38 \mu \mathrm{m}$ which results in a galena "liberation" of only $77 \%$. A higher liberation of galena in the lead regrind circuit is compromised by classification of the galena by the hydrocyclones. Because recovery of "liberated" galena in the lead cleaners is higher than recovery of unliberated galena it is suggested that better liberation of galena will improve lead recovery. This would be facilitated by rejecting more pyrite in the lead rougher-scavengers.

Galena which is associated with siderite and sphalerite does not liberate easily. Siderite, especially, remains stubbornly locked to galena throughout the circuit. Most of the locked galena lost to tailings is associated with siderite. Of the small portion of galena 
reporting to the zinc concentrate $36 \%$ is associated with sphalerite. Therefore the association of galena with siderite and sphalerite seems to have an adverse effect on galena recovery.

Lead grade is mostly affected by the presence of impurities not attached to galena. This includes $5.1 \%$ sphalerite and $5.0 \%$ siderite, as well as lesser quantities of pyrite, barite, muscovite and quartz. Non-selective behaviour of sphalerite and siderite is indicated by the presence of such large amounts of these minerals in the lead concentrate as well as the presence of significant portions of "liberated" sphalerite, in the final tailings.

The presence of both sphalerite and siderite not locked with galena in the lead concentrate indicates possible activation of those minerals. Further evidence of activation is the fact that galena locked with sphalerite and siderite in binary particles has higher recovery rates than galena locked in pyrite binaries in the lead concentrate.

There is evidence that several ions can activate sphalerite in the lead circuit including $\mathrm{Cu}, \mathrm{Pb}, \mathrm{Ag}$ (Chryssoulis et al 1992) and $\mathrm{Fe}^{2+}$ (Leroux et al 1986). Both $\mathrm{Fe}^{2+}$, primarily from grinding but also from the breakdown of marcasite and pyrrhotite, and $\mathrm{Ag}$ due to the breakdown of acanthite, are candidates for the role of sphalerite activation in the Faro circuit. However, both of these ions readily complex with cyanide. The best candidate is lead, in the form of $\mathrm{Pb}^{2+}$, which is not complexed by cyanide and may be released during grinding and subsequently coat the sphalerite grains as $\mathrm{PbS}$ (Chryssoulis et al 1992). It has been suggested that siderite may be activated by $\mathrm{Cu}$ or $\mathrm{Pb}$ ions (Gaudin 1939, Taggart 1945). However, the presence of secondary copper minerals was not 
detected.

The quantities of the three major diluent gangue minerals associated with galena only in the lead concentrate are $8.0 \%$ sphalerite, $1.6 \%$ pyrite and $1.2 \%$ siderite (Table 27 ). However Table 23 shows that more unliberated galena is associated with siderite than with either sphalerite or pyrite. This indicates that the siderite is distributed, as relatively small grains, among the galena-bearing particles whereas sphalerite and pyrite are distributed as coarse grains. This further suggests that the sphalerite is recovered in the lead concentrate more due to activation than locking with galena.

Due to the fact that $66 \%$ of the unrecovered galena in the lead scavenger tails is not "liberated" (Table 18) it is concluded that galena recovery is most adversely affected by inadequate liberation. The fineness of the galena is the overriding factor affecting lead recovery in Faro ore. The fact that the major diluents in the final lead concentrate are not attached to galena indicates that lead grade is adversely affected by poor selectivity. It is suggested that activation of sphalerite and siderite, possibly due to lead, is the major factor affecting lead grade.

Zinc recovery and grade

The concentrator recovers $77 \%$ of the zinc (Appendix 10) at a grade of $51 \%$ in the zinc concentrate. The sphalerite in the zinc concentrate is mostly "liberated" $(95 \%)$ and is in the $-38 \mu \mathrm{m}$ sieve fraction ( $82 \%)$. The concentrator loses $7.9 \%$ of the zinc in the lead concentrate. There most of the sphalerite (55\%) is attached to galena, however $25 \%$ is free. The greater portion of sphalerite is lost to the final tailings (15\%) where it is mostly 
"liberated" (75\%) and a large portion is free (33\%). Only $1 \%$ is encapsulated. It is clear that most of the zinc losses are not due to poor liberation. The reasons for sphalerite losses to tailings are speculative. Mechanical entrainment is one alternative or possibly depression by $\mathrm{Fe}^{3+}$ or oxidized coatings of lead (Chryssoulis et al 1992) which have prevented copper activation. Most of the sphalerite lost to the tailings is associated with siderite and to a lesser extent, galena and pyrite.

Most of the sphalerite reporting to the lead concentrate is "liberated" and associated with galena. This indicates that it may be affected by activation more than by association with galena as previously discussed.

Dilution of the zinc concentrate is mainly caused by the presence of siderite which is attached to sphalerite and the presence of free galena (Table 27). Most of the locked sphalerite is associated with chalcopyrite (Table 22) which indicates that the chalcopyrite is fine-grained and disseminated in the sphalerite because on a weight basis it is not a significant diluter (Table 27). A large portion (83\%) of all galena in the zinc circuit locked in binaries with sphalerite is distributed to the zinc concentrate (Table 25). Sphalerite in binary particles with chalcopyrite and siderite are also strongly recovered in the zinc concentrate. Siderite appears to be non-selective given that it is also strongly associated with sphalerite in the tailings. This indicates that chalcopyrite locked with sphalerite may assist the recovery of sphalerite in the zinc circuit.

Zinc grade is also affected by the recovery of diluent minerals not locked with sphalerite. About $3 \%$ of the zinc concentrate consists of minerals which are not associated with sphalerite, a major portion of these are galena and siderite. Overall, the data indicate 
that sphalerite's association with siderite, galena and chalcopyrite are causes of low zinc grade. An important upper limit on zinc grade is the $\mathrm{Zn}$ content of the sphalerite which averages about $55 \%$.

Liberation of Tetrahedrite and Gold-silver

A search for silver-bearing minerals in the three sieve fractions of the final tailings found only two tetrahedrite grains in the $-38 \mu \mathrm{m}$ fraction and both grains were free. In the lead concentrate seven tetrahedrite grains were found all of which were locked. The zinc concentrate showed one tetrahedrite grain which was locked. In the lead first cleaner tail were found 40 tetrahedrite grains of which 19 were free. In the zinc first cleaner tail were found 2 tetrahedrite grains of which all were locked. Given that about one-half of the tetrahedrite grains are free in all the streams examined it is assumed that most of the tetrahedrite is "liberated" ( $+70 \%$ class). Four gold-silver alloy grains were found in the lead scavenger tails and all four were free. Neither acanthite nor native silver was found in any of the concentrator samples.

Mineral Associations of Tetrahedrite

Thirty one grains of locked tetrahedrite were found in the concentrator samples, most of these were found in the lead first cleaner tails. Twenty one were found associated with galena, seven with chalcopyrite, five with sphalerite, four with barite, four with carbonate and one with pyrite. All the tetrahedrites in the lead concentrate were locked with galena. One grain of tetrahedrite found in the final zinc concentrate was locked with 
sphalerite and all the tetrahedrite grains in the final tailings were free.

Silver Distribution in Concentrator Feed

The mineralogical distribution of silver in the Faro concentrator feed was determined by identifying the significant silver carriers, measuring their silver content and their abundance in each stream of the concentrator and then performing a material balance for the silver in each mineral carrier.

The identity of the silver carriers has previously been established as well as the silver content of galena and tetrahedrite. Dynamic Secondary Ion Mass Spectroscopy (SIMS) was used to analyze all the major sulphide minerals, except for galena, to determine the trace amounts of silver contained in each of these minerals. Results of this analysis are shown in Table 28.

TABLE 28

AVERAGE SILVER CONTENT OF SULPHIDE MINERALS IN FARO ORE BY SIMS ANALYSIS

\begin{tabular}{|c|c|}
\hline MINERAL & $\begin{array}{c}\text { SILVER } \\
\text { CONTENT } \\
\text { (PPM) }\end{array}$ \\
\hline MARCASTTE & 62 \\
\hline CHALCOPYRITE & 35 \\
\hline SPHALERTTE & 21 \\
\hline PYRTTE & 2 \\
\hline PYRRHOTITE & 2 \\
\hline
\end{tabular}

An attempt to estimate the abundance of tetrahedrite by means of an antimony balance (assay data are given in Appendix 10) gave unrealistically high concentrations of tetrahedrite. It is felt that this result may be attributed to the presence of several minerals 
which contain significant amounts of $\mathrm{Sb}$ at concentrations below the detection limit of the microprobe. The tetrahedrite quantities were estimated by means of counting the number of tetrahedrite grains found in an estimated number of particles scanned in each of the concentrator samples examined. The assumptions are that the average ore specific gravity is 4.0 and the tetrahedrite grains have the same average grain size as the rest of the particles.

A materials balance was performed on the measured silver distributions to improve the accuracy of the calculated distribution in the concentrator feed and to calculate the distributions of each silver-bearing mineral in the concentrator (Table 29). For those samples which were not scanned for silver minerals the abundances of tetrahedrite were estimated and given a very large relative error for the materials balance calculation.

\section{Mineralogical Distribution of Silver in Faro Concentrator}

The determination of the silver content of the silver-bearing minerals allows the mineralogical distribution of the silver to be calculated in each stream of the concentrator. The distributions in each stream sample as well as the overall distribution in the concentrator of the silver-bearing minerals were calculated on the basis of the total balanced silver assay. The data for selected streams in the concentrator are shown in Table 29. The silver distribution in Faro ore is given by the distribution of the Faro concentrator feed. The data indicate that galena is the major silver-bearing mineral followed by marcasite, tetrahedrite, sphalerite, pyrite, chalcopyrite, and pyrrhotite. A large portion of the silver $(21 \%)$ is unaccounted for. Silver due to native silver and gold-silver 


\section{TABLE 29}

MINERALOGICAL DISTRIBUTION OF SILVER IN SELECTED STREAMS OF FARO CONCENTRATOR

\begin{tabular}{|c|c|c|c|c|c|c|}
\hline & \multicolumn{2}{|c|}{ FEED } & \multicolumn{2}{|c|}{ LEAD CONC. } & \multicolumn{2}{|c|}{ 2INC CONC. } \\
\hline & $\begin{array}{c}\text { WTX } \\
\text { SAMPLE } \\
\end{array}$ & $\begin{array}{l}\text { WTX } \\
\text { FEED } \\
\end{array}$ & $\begin{array}{c}\text { NTX } \\
\text { SAMPLE } \\
\end{array}$ & $\begin{array}{l}\text { WTX } \\
\text { FEED } \\
\end{array}$ & $\begin{array}{c}\text { WTX } \\
\text { SAMPLE } \\
\end{array}$ & $\begin{array}{l}\text { WTX } \\
\text { FEED }\end{array}$ \\
\hline Galena & 63.2 & 100.00 & 98.3 & 82.44 & 23.7 & 3.53 \\
\hline Marcasite & 7.4 & 100.00 & 0.1 & 0.72 & 0.5 & 0.59 \\
\hline Chal copyrite & 0.3 & 100.00 & 0.1 & 15.48 & 1.2 & 35.74 \\
\hline Sphalerite & 3.2 & 100.00 & 0.5 & 7.85 & 27.5 & 77.01 \\
\hline Pyrite & 0.8 & 100.00 & 0.1 & 0.70 & 0.1 & 0.61 \\
\hline Pyrrhotite & 0.1 & 100.00 & 0.1 & 8.23 & 0.1 & 4.99 \\
\hline Tetrahedrite & 4.5 & 100.00 & 1.0 & 11.86 & 1.0 & 2.54 \\
\hline \multirow[t]{3}{*}{ Unknown" } & 20.5 & 100.00 & 0.0 & 0.03 & 45.9 & 17.67 \\
\hline & \multicolumn{2}{|c|}{ FINAL TAILS } & \multicolumn{2}{|c|}{ PB IST CL.TAILS } & & \\
\hline & $\begin{array}{c}\text { WTX } \\
\text { SAMPLE } \\
\end{array}$ & $\begin{array}{l}\text { WTX } \\
\text { FEED } \\
\end{array}$ & $\begin{array}{c}\text { WTX } \\
\text { SAMPLE }\end{array}$ & $\begin{array}{l}\text { WTX } \\
\text { FEED } \\
\end{array}$ & & \\
\hline Galena & 21.1 & 13.37 & 45.0 & 22.58 & & \\
\hline Marcasite & 18.6 & 98.68 & 5.0 & 21.77 & & \\
\hline Chal copyrite & 0.4 & 48.77 & 1.3 & 150.42 & & \\
\hline Spholerite & 1.3 & 15.10 & 4.3 & 42.58 & & \\
\hline Pyrite & 1.9 & 98.69 & 0.5 & 21.78 & & \\
\hline Pyrrhotite & 0.1 & 84.03 & 0.1 & 18.05 & & \\
\hline Tetrahedrite & 6.4 & 85.60 & 36.9 & 259.92 & & \\
\hline Unknown" & 50.3 & 82.33 & 7.0 & 10.85 & & \\
\hline
\end{tabular}

includes negligible amounts contained in acanthite, native silver and gold-silver alloy.

alloy is insignificant to the total silver balance so they are included in the unknown group.

Due to the fact that galena contains $63 \%$ of the silver in the ore the overall recovery of silver is dependent on the recovery of galena. It is seen that $82 \%$ of silver in galena is recovered in the lead concentrate. The data show that although tetrahedrite concentrates in the first cleaner tails it is ultimately lost (78\%) to the final tails. The other sulphide minerals collectively account for about $16 \%$ of the silver in the feed. Except for 
sphalerite and chalcopyrite most of the silver contained in these minerals is lost to tailings.

The unaccounted $21 \%$ of the total silver in the concentrator feed probably is contained in acanthite in the unprocessed ore. The absence of acanthite grains in any of the concentrator samples that were searched may be due to their being leached by cyanide. $\mathrm{NaCN}$ is added as a depressant for pyrite and sphalerite in the lead circuit and it is well known that acanthite readily dissolves in dilute cyanide solutions (Wyslouzil and Salter 1990). Some of this silver may be reprecipitated onto the surfaces of other sulphide minerals in the mineral slurry (Chryssoulis et al 1984).

Support for the silver distribution in Faro ore given in Table 29 and the proposition that the unknown silver is in fact "visible" silver was obtained from a laboratory cyanide leach test. The leach test was performed on $1 \mathrm{~kg}$ core sample of $2 \mathrm{E}$ ore (ground to $80 \%-16 \mu \mathrm{m}$ ), because there was insufficient concentrator feed remaining. The result was that $65 \%$ of the silver is unleachable, or "invisible". Assuming that about $10 \%$ of the silver in the galena, $50 \%$ of the silver in the tetrahedrite and all of the silver in the unknown group was leached then the remaining "invisible portion is calculated to be $71 \%$ (Wyslouzil and Salter 1990). The close agreement supports the proposition that the source of the silver in the unknown portion is "visible", namely, acanthite. If the unknown silver was present as submicron inclusions the leach test would have indicated a much higher proportion of invisible silver. If the silver is present as submicron tetrahedrite it is reasonable to assume the distribution of the unknown group would have been much higher in the lead first cleaner tails. In fact, the distribution of tetrahedrite, as 
a relative percentage of that in the lead circuit feed, is $260 \%$ whereas the distribution of "unknown" to that stream is only $11 \%$ (Table 29 ).

In summary, the overriding factor affecting silver recovery is its distribution in galena. All the silver recovered in the concentrator is due to silver contained in galena recovered in the lead concentrate. It is interpreted that the major silver losses are due to it being distributed in acanthite in the unprocessed ore. During processing acanthite dissolves and reprecipitates onto the surfaces of other minerals which report to the zinc concentrate and tailings. To a lesser extent silver in galena accounts for some of the losses to the tailings. These losses in galena are related to the fineness of galena and its lower liberation.

Ironically, losses of silver contained in tetrahedrite are due to tetrahedrite being too well liberated. Tetrahedrite recovery in the lead circuit is enhanced by its association with galena.

Deleterious Minerals

Minerals such as kaolinite, talc, chlorite, and graphite are known to form slime coatings on sulphide minerals rendering them non-selective. None of these minerals are present in sufficient amounts in the samples studied to be detrimental to metal recovery. Fine-grained muscovite is present in large quantities in the concentrator feed but no indication was found that it is interfering with metal recovery.

Marcasite and pyrrhotite are undesirable sulphide minerals due to their instability 
in water in which they release $\mathrm{Fe}$ ions which can render sphalerite non-selective and which consume cyanide (Wyslouzil and Salter 1990). Both minerals are present in sufficient amounts in Faro ore to affect sphalerite in the lead circuit. Similarly, acanthite, if present as previously proposed, may provide a source of $\mathrm{Ag}$ ions which prematurely activate sphalerite in the lead circuit. The depression of pyrite in the lead circuit may also be reduced by the cyanide losses. Secondary copper, secondary lead and iron oxide minerals were not observed.

Table 30 summarizes the mineralogical factors which affect grade and recovery in Faro ore.

\section{TABLE 30}

MINERALOGICAL FACTORS WHICH REDUCE METAL RECOVERY AND GRADE IN FARO CONCENTRATOR

\begin{tabular}{|c|l|l|}
\hline \multicolumn{1}{|c|}{ RECOVERY } & \multicolumn{1}{|c|}{ GRADE } \\
\hline ZINC & $\begin{array}{l}\text { "Liberated" sphalerite lost to tailings (due } \\
\text { to depression by ferric ion or oxidized } \\
\text { lead?). } \\
\text { "Liberated" sphalerite lost to lead conc. } \\
\text { (due to surface coatings of PbS?). }\end{array}$ & $\begin{array}{l}\text { Presence of siderite and galena locked } \\
\text { with sphalerite due to strong association } \\
\text { with both minerals. }\end{array}$ \\
& $\begin{array}{l}\text { Presence of free gangue including galena } \\
\text { and siderite. }\end{array}$ \\
\hline LEAD & $\begin{array}{l}\text { Fine-grained galena lost to zinc circuit due } \\
\text { to locking and association with siderite, } \\
\text { sphalerite and pyrite. } \\
\text { Misclassification of locked galena in lead } \\
\text { regrind minimizes galena liberation. }\end{array}$ & $\begin{array}{l}\text { Presence of free gangue, mostly sphalerite } \\
\text { and siderite, possibly due to activation. }\end{array}$ \\
\hline SILVER & $\begin{array}{l}\text { Presence of "liberated" sphalerite possibly } \\
\text { due to activation and also due to strong } \\
\text { association with galena }\end{array}$ \\
\hline & $\begin{array}{l}\text { Silver in acanthite possibly lost due to } \\
\text { Some silver in galena lost to tailings. } \\
\text { Silver in tetrahedrite lost to tailings. }\end{array}$ & \\
\hline
\end{tabular}




\section{CHAPTER 6}

\section{MINERALOGY OF THE VANGORDA ORE TYPES}

\section{INTRODUCTION}

The ore types of the Vangorda deposit are very similar to those of the Faro deposit and the same ore scheme is used to define them (Appendix 1). Only the three major ore types are selected for this study; namely, 4A, 4E and $4 \mathrm{G}$.

Due to its near surface location the Vangorda ore body has suffered oxidation from seepage of groundwater. Significant mineralogical changes have resulted in all Vangorda ore types.

Ten samples were taken, in consultation with Curragh geological staff, by sampling representative drill cores from sections $3 \mathrm{E}, 11 \mathrm{E}, 12 \mathrm{E}, 17 \mathrm{E}$ and $21 \mathrm{E}$ of the Vangorda deposit (Figure 7). From these samples, fifteen polished sections were made for further examination. In addition, Curragh Resources supplied the author with 71 polished sections and 11 polished thin sections of a representative suite of samples. A list of all the samples and their locations is shown in Appendix 13. From the total of these polished sections several of the most representative of each ore type were selected for determination of grain size distributions and associations of the important ore minerals by image analysis. The remaining core samples of each ore type was combined, crushed, blended and riffled. The crushed product for each ore type was then assayed and a modal analysis was performed.

Forty minerals were identified in drill core and concentrator samples of Vangorda 
ore and are listed in Table 1. Microprobe analyses of sphalerite in samples of the concentrator concentrate and tailings are given in Appendix 14. Microprobe analyses of galena in samples taken from the lead concentrate are shown in Appendix 15. Average silver and antimony contents of $825 \mathrm{ppm}$ and $923 \mathrm{ppm}$ respectively were found in 101 grains analyzed but no As nor Bi was detected. Microprobe analyses of tetrahedritetennantite are given in Appendix 16. In contrast to Faro ore, the tetrahedrite-tennantite grains have a composition closer to the tennantite end-member and contain very little silver. Microprobe analyses of randomly selected Vangorda carbonate grains are shown in Appendix 17. Overall, ankerite is the most common carbonate species in the core samples. Some carbonate grains contain zinc as a minor constituent.

\section{A ORE}

The 4A ore type, a ribbon-banded graphitic quartzite, is normally low grade and peripheral to the deposit, comprising only approximately $5 \%$ of the Vangorda orebody. This ore type makes up much of the uppermost horizon associated with the carbonaceous phyllite at the base of the Vangorda formation.

Five polished sections and six polished thin sections were made for examination. The minerals present and their textural relationships are almost identical to that of $2 \mathrm{~A}$ ore from Faro and will not be repeated here. The chemical and modal analyses of two combined core samples of $4 \mathrm{~A}$ ore are shown in Tables 31 and 32 , respectively. The $4 \mathrm{~A}$ ore type contains significantly more arsenopyrite than $2 \mathrm{~A}$ ore.

The grain size distributions of pyrite, sphalerite, galena, chalcopyrite, quartz and 
TABLE 31

ASSAYS OF VANGORDA ORE TYPES (WT\%)

\begin{tabular}{|c|c|c|c|}
\hline & $4 A$ & $4 E$ & $4 G$ \\
\hline $\mathrm{Zn}$ & 4.2 & 2.9 & 6.6 \\
\hline $\mathrm{Pb}$ & 2.4 & 2.4 & 4.6 \\
\hline $\mathrm{Ag}(\mathrm{ppm})$ & 30.9 & 23.7 & 85.4 \\
\hline $\mathrm{Au}(\mathrm{ppm})$ & 0.48 & 0.86 & 0.34 \\
\hline $\mathrm{Fe}$ & 5.7 & 30.2 & 14.1 \\
\hline $\mathrm{Cu}$ & $<0.05$ & 0.3 & 0.1 \\
\hline $\mathrm{As}$ & 0.33 & 0.28 & 0.03 \\
\hline $\mathrm{Cd}(\mathrm{ppm})$ & $<100$ & $<100$ & 100 \\
\hline $\mathrm{Sb}(\mathrm{ppm})$ & 100 & 100 & 200 \\
\hline $\mathrm{Hg}(\mathrm{ppm})$ & 20 & $<10$ & 30 \\
\hline $\mathrm{Mn}$ & $<0.03$ & 0.6 & 0.6 \\
\hline $\mathrm{C}_{8}$ & 0.61 & 0.22 & 0.15 \\
\hline $\mathrm{C}_{\omega s}$ & $<0.02$ & $<0.02$ & $<0.02$ \\
\hline
\end{tabular}

arsenopyrite are shown in Table 33 and Figure 35. A comparison with 2A ore (Figure 9) shows that pyrite in $4 \mathrm{~A}$ ore is much finer-grained, having a $\mathrm{K}_{80}$ of $75 \mu \mathrm{m}$ whereas that of $2 \mathrm{~A}$ ore has a $\mathrm{K}_{80}$ of about $212 \mu \mathrm{m}$. Sphalerite is about the same size in the two ores, but galena is much coarser in $4 \mathrm{~A}$, having a $\mathrm{K}_{80}$ of about $38 \mu \mathrm{m}$ compared to $13 \mu \mathrm{m}$ in 2A. Individual quartz grains could not be discriminated by the image analyzer so that the "grain size" given in Table 33 and Figure 35 is that of clusters of quartz grains.

The mineral associations of sphalerite and galena as measured by the perimeter association technique are shown in Table 34 . Galena is strongly associated with quartz ( $84 \%$ of its perimeter) and preferential association with quartz is indicated (INDEX = .83). 
TABLE 32

MINERAL QUANTITIES IN THE VANGORDA ORE TYPES (W
\begin{tabular}{|c|c|c|c|}
\hline & \multicolumn{1}{|c|}{4 A } & \multicolumn{1}{c|}{4 E } & \multicolumn{1}{c|}{4 G } \\
\hline Pyrite & 8.59 & 52.89 & 27.18 \\
\hline Galen & 2.77 & 2.77 & 5.31 \\
\hline Sphalerite & 7.20 & 4.97 & 11.32 \\
\hline Pynthotite & 0.12 & 1.19 & 0.03 \\
\hline Chalcopyrite & 0.01 & 0.87 & 0.29 \\
\hline Arsenopyrite & 0.65 & 0.48 & 0.26 \\
\hline Barite & 0.17 & 13.94 & 45.55 \\
\hline Quarte & 64.61 & 6.86 & 1.03 \\
\hline Ankerite & 11.38 & 12.18 & 3.39 \\
\hline Siderite & 4.50 & 2.19 & 2.92 \\
\hline Magnetite & 0.00 & 1.66 & 2.72 \\
\hline
\end{tabular}

- these data were obtained by a combination of assaying and image analysis

includes minor marcasite; includes trace kaolinite

includes muscovite and trace calcile

includes trace clinochlore, celsian and goethite

The association of galena with quartz generally trends downwards from $85 \%$ to $80 \%$ as galena's grain size becomes coarser. Galena shows non-preferred association with sphalerite (INDEX $=-.76$ ). The association of galena with sphalerite increases from $4 \%$ to a high of $10 \%$ as galena's grain size becomes coarser indicating that, as found in $2 \mathrm{~A}$ ore, coarse-grained galena is more closely associated with sphalerite than fine-grained galena is. Similarly, with muscovite galena's association is non-preferential (INDEX = $-82)$.

Sphalerite is strongly associated with quartz (74\%) and has a preferential association with quartz (INDEX $=.48)$. However it shows non-preferrential association with galena (INDEX $=-.70)$ and muscovite $($ INDEX $=-.76)$. 
TABLE 33

GRAIN SIZE DISTRIBUTIONS FOR VANGORDA 4 A ORE (CUMULATTVE \% PASSING)

\begin{tabular}{|c|c|c|c|c|c|c|}
\hline $\begin{array}{l}\text { GRAIN } \\
\text { SIZE } \\
(\mu \mathrm{M})\end{array}$ & PY & SP & GAL & $C P$ & QTZ & ASP \\
\hline 3.4 & 1.13 & 1.67 & 21.90 & 2.54 & & 6.25 \\
\hline 4.7 & 1.80 & 2.65 & 28.83 & 3.55 & & 13.47 \\
\hline 6.7 & 3.89 & 6.14 & 39.09 & 8.00 & & 35.23 \\
\hline 9.4 & 8.17 & 13.01 & 49.56 & 22.46 & & 52.98 \\
\hline 13 & 14.08 & 21.63 & 57.94 & 36.06 & 0.44 & 68.52 \\
\hline 19 & 21.85 & 31.29 & 66.00 & 54.86 & 0.86 & 76.37 \\
\hline 26 & 33.79 & 44.80 & 76.22 & 65.72 & 1.49 & 80.20 \\
\hline 38 & 49.85 & 57.56 & 84.43 & 86.97 & 3.11 & 91.87 \\
\hline 53 & 68.35 & 71.26 & 92.08 & 89.27 & 4.90 & 95.63 \\
\hline 75 & 83.25 & 84.68 & 97.30 & 100.00 & 8.06 & 100.00 \\
\hline 106 & 91.87 & 93.99 & 98.82 & & 12.15 & \\
\hline 150 & 98.69 & 98.06 & 100.00 & & 18.33 & \\
\hline 212 & 99.90 & 99.61 & & & 26.82 & \\
\hline 300 & & & & & 38.49 & \\
\hline 425 & & & & & 52.75 & \\
\hline 600 & & & & & 68.65 & \\
\hline 850 & & & & & 83.92 & \\
\hline
\end{tabular}

The texture of $4 \mathrm{~A}$ ore is dominated by the abundant coarse-grained quartz with interstitial pyrite, sphalerite and fine-grained galena disseminated in the quartz. Pyrite has about the same grain size as the sphalerite but the galena is much finer-grained. In $4 \mathrm{~A}$ ore the pyrite grains form individual clusters of subhedral to anhedral grains. Sphalerite tends to occur as long sinuous bands in the quartz matrix as also observed in $2 \mathrm{~A}$ ore. Arsenopyrite concentrates in the $4 \mathrm{~A}$ ore (Table 32 ) in which it occurs as very small 


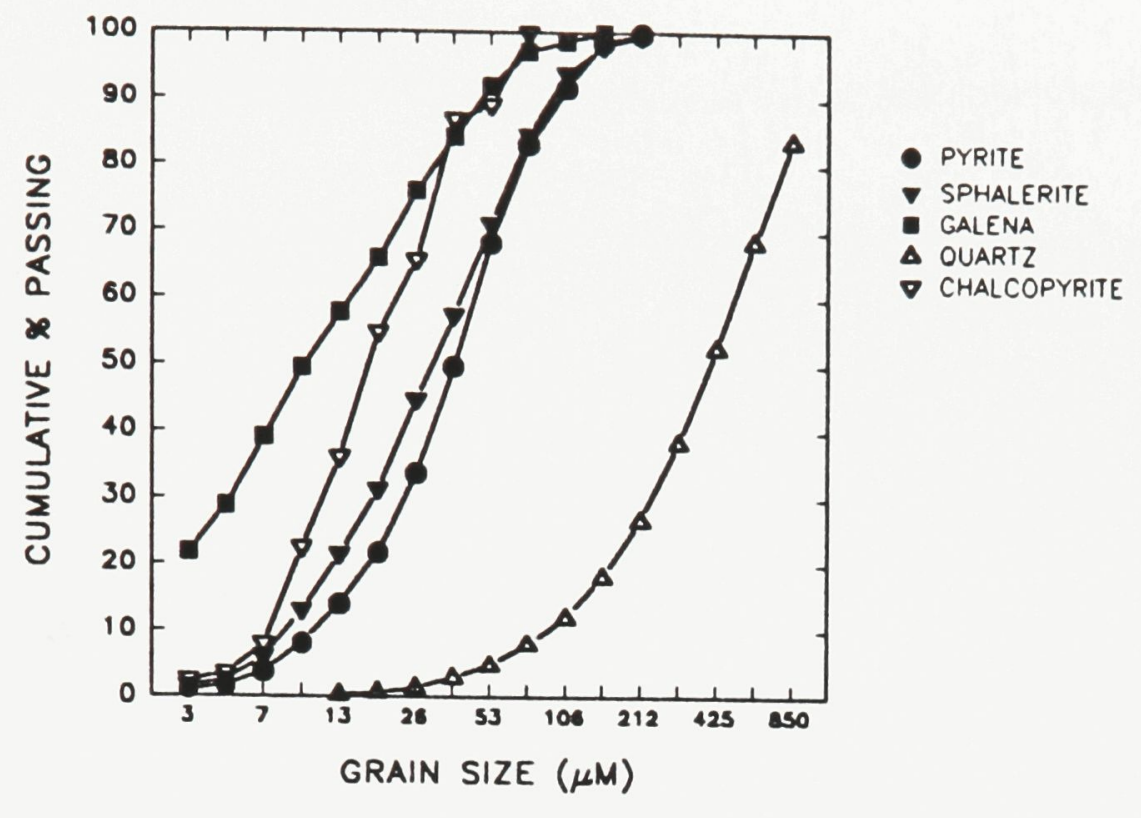

Figure 35 Grain size distributions of ore minerals in Vangorda 4A ore.

subhedral grains associated with pyrite. Muscovite is a major mineral in the siliceous ore types of Vangorda. In 4A ore, where it is best developed, it forms thin aligned bands associated with the opaque carbonaceous grains. It also occurs as disseminated grains in the quartz matrix with less pronounced alignment.

\section{E ORE}

The $4 \mathrm{E}$ ore type is the second most important comprising approximately $20 \%$ of the Vangorda orebody and is found predominantly in the main horizon. Thirty one polished sections of this ore type were examined.

The chemical and modal analyses of three combined core samples of $4 \mathrm{E}$ ore are shown in Tables 31 and 32, respectively. The grain size distributions of pyrite, sphalerite, 
TABLE 34

MINERAL ASSOCIATIONS OF GALEMA AMO SPMALERITE IN 4A ORE BY GRAIN SIZE (PERIMETERX)

GALEMA

\begin{tabular}{|c|r|r|r|r|r|r|r|r|}
\hline $\begin{array}{c}\text { GAL GRAIN } \\
\text { SIZE } \\
(\mu M)\end{array}$ & OTZ & \multicolumn{1}{|c|}{ SID } & PY & CP & BAR & PO & MUSC & SP \\
\hline+150 & 0 & 0 & 0 & 0 & 0 & 0 & 0 & 0 \\
\hline+106 & 80 & 1 & 4 & 0 & 0 & 0 & 12 & 3 \\
\hline+75 & 97 & 0 & 2 & 0 & 0 & 0 & 1 & 0 \\
\hline+53 & 80 & 0 & 5 & 0 & 0 & 0 & 6 & 10 \\
\hline+38 & 82 & 0 & 3 & 2 & 0 & 0 & 6 & 7 \\
\hline+26 & 80 & 1 & 7 & 2 & 0 & 0 & 5 & 6 \\
\hline+9 & 84 & 0 & 5 & 1 & 0 & 0 & 4 & 5 \\
\hline+1 & 85 & 0 & 7 & 1 & 0 & 0 & 4 & 4 \\
\hline ALL S1ZES & 84 & 0 & 6 & 1 & 0 & 0 & 4 & 4 \\
\hline EXPECTED & 46 & 0 & 13 & 0 & 0 & 0 & 23 & 17 \\
\hline INDEX & .83 & $n$ & -.54 & $n$ & $n a$ & $n$ & -.82 & -.76 \\
\hline
\end{tabular}

SPHALERITE

\begin{tabular}{|c|c|c|c|c|c|c|c|c|}
\hline $\begin{array}{c}\text { SP GRAIN } \\
\text { SIZE } \\
(\mu M) \\
\end{array}$ & QTZ & SID & PY & CP & BAR & PO & MUSC & GAL \\
\hline+150 & 75 & 0 & 14 & 2 & 0 & 0 & 4 & 5 \\
\hline+106 & 61 & 0 & 28 & 3 & 0 & 0 & 6 & 3 \\
\hline$+\pi 5$ & 72 & 0 & 15 & 3 & 0 & 0 & 5 & 5 \\
\hline+53 & 72 & 0 & 17 & 1 & 0 & 0 & 6 & 4 \\
\hline+38 & 76 & 0 & 13 & 2 & 0 & 0 & 5 & 4 \\
\hline+26 & 78 & 0 & 11 & 2 & 0 & 0 & 7 & 3 \\
\hline+9 & 78 & 0 & 12 & 2 & 0 & 0 & 6 & 2 \\
\hline+1 & 0 & 0 & 0 & 0 & 0 & 0 & 0 & 0 \\
\hline ALL SIZES & 74 & 0 & 14 & 2 & 0 & 0 & 6 & 3 \\
\hline EXPECTED & 50 & 0 & 14 & 1 & 0 & 0 & 25 & 10 \\
\hline INDEX & .48 & na & 0 & 1.0 & no & na & -.76 & -.70 \\
\hline
\end{tabular}


galena, chalcopyrite, quartz and pyrrhotite are shown in Table 35 and Figure 36 . The data show that pyrite, sphalerite and galena are all much finer-grained in $4 \mathrm{E}$ ore than in $2 \mathrm{E}$ ore (Figure 12).

TABLE 35

GRAIN SLZE DISTRIBUTIONS FOR VANGORDA 4E ORE (CUMULATIVE \% PASSING)

\begin{tabular}{|c|c|c|c|c|c|c|}
\hline $\begin{array}{c}\text { GRAD } \\
\text { SIZE } \\
(\mu \mathrm{M})\end{array}$ & PY & SP & GAL & $\mathrm{CP}$ & QTZ & PO \\
\hline 3.4 & 1.17 & 3.35 & 24.67 & 4.02 & 1.85 & 5.74 \\
\hline 4.7 & 1.81 & 5.19 & 32.29 & 5.88 & 2.68 & 14.27 \\
\hline 6.7 & 3.81 & 11.11 & 44.93 & 14.31 & 5.80 & 18.21 \\
\hline 9.4 & 7.79 & 24.06 & 57.43 & 32.21 & 12.79 & 27.86 \\
\hline 13 & 14.69 & 38.75 & 69.16 & 52.25 & 22.31 & 62.16 \\
\hline 19 & 24.13 & 50.75 & 76.57 & 62.30 & 32.71 & 71.46 \\
\hline 26 & 37.71 & 66.48 & 84.68 & 80.53 & 49.47 & 84.96 \\
\hline 38 & 52.45 & 77.57 & 89.78 & 88.86 & 63.61 & 96.52 \\
\hline 53 & 68.22 & 86.39 & 94.53 & 99.96 & 77.51 & 100.00 \\
\hline 75 & 82.00 & 92.68 & 97.26 & 100.00 & 88.05 & \\
\hline 106 & 92.41 & 97.13 & 98.80 & & 95.18 & \\
\hline 150 & 97.97 & 99.13 & 99.60 & & 99.26 & \\
\hline 212 & 99.53 & 99.78 & 100.00 & & 100.00 & \\
\hline
\end{tabular}

The associations of sphalerite and galena are shown in Table 36. The data show that galena has a strong association with pyrite (58\%) but also it has a fairly strong association with the carbonates, siderite $(15 \%)$ and ankerite $(16 \%)$. The data show that fine-grained galena $(-26 \mu \mathrm{m}$ grain fraction) is more closely associated with pyrite than coarse-grained galena. However, coarse-grained galena is more closely associated 


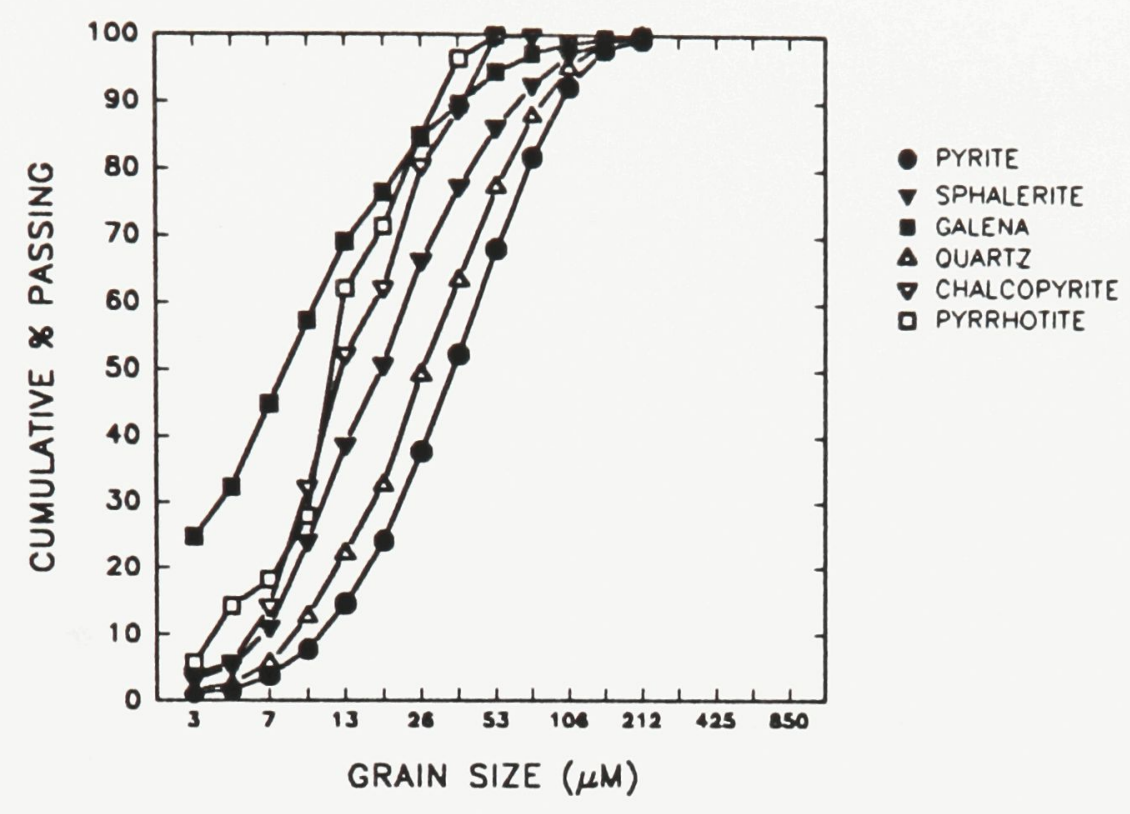

Figure 36 Grain size distributions of ore minerals in $4 \mathrm{E}$ ore.

with sphalerite and siderite than fine-grained galena.

Sphalerite is also closely associated with pyrite $(50 \%)$ and the data show that sphalerite is also more closely associated with pyrite at fine grain sizes than at coarse grain sizes. Coarse-grained sphalerite is more closely associated with ankerite than finegrained sphalerite.

The minerals present and their textural relationships are similar to $2 \mathrm{E}$ ore and their description will not be repeated. There are significant differences however. The texture of pyritic $4 \mathrm{E}$ ore is dominated by texture of the pyrite which is much finer-grained than its 2E counterpart. Pyrite most often occurs as closely crowded, fine to medium-grained euhedral to subhedral grains up to $400 \mu \mathrm{m}$ in diameter (Plate 11). Sphalerite, galena and chalcopyrite are often interstitial to the pyrite grains and rarely as rounded inclusions. 
TABLE 36

MINERAL ASSOCIATIONS OF GALEMA AND SPHALERITE IN 4 ORE BY GRAIN SIZE (PERIMETERX)

galema

\begin{tabular}{|c|c|c|c|c|c|c|c|c|}
\hline $\begin{array}{c}\text { GAL GRAIN } \\
\text { SIZE } \\
\text { (MN) }\end{array}$ & QTZ & S10 & PY & $C P$ & BAR & PO & ANK & SP \\
\hline+150 & 1 & 54 & 45 & 0 & 0 & 0 & 0 & 0 \\
\hline+106 & 4 & 37 & 56 & 0 & 0 & 0 & 0 & 3 \\
\hline+75 & 3 & 30 & 39 & 0 & 0 & 0 & 14 & 14 \\
\hline+53 & 1 & 23 & 47 & 0 & 0 & 0 & 16 & 13 \\
\hline+38 & 1 & 16 & 50 & 0 & 0 & 0 & 22 & 11 \\
\hline+26 & 2 & 17 & 40 & 0 & 0 & 0 & 26 & 15 \\
\hline+9 & 2 & 14 & 59 & 0 & 0 & 0 & 15 & 10 \\
\hline+1 & 2 & 11 & 65 & 0 & 0 & 0 & 15 & 7 \\
\hline ALL SIZES & 2 & 15 & 58 & 0 & 0 & 0 & 16 & 9 \\
\hline EXPECTED & 9 & 16 & 50 & 0 & 0 & 0 & 11 & 14 \\
\hline INDEX & -.78 & -.06 & .16 & na & na & na & .45 & -.36 \\
\hline
\end{tabular}

SPHALERITE

\begin{tabular}{|c|c|c|c|c|c|c|c|c|}
\hline $\begin{array}{l}\text { SP GRAIN } \\
\text { SIZE } \\
(\mu M)\end{array}$ & QTZ & SID & PY & CP & BAR & PO & ANK & GAL \\
\hline+150 & 4 & 15 & 38 & 1 & 0 & 0 & 28 & 14 \\
\hline+106 & 3 & 13 & 43 & 0 & 0 & 0 & 28 & 13 \\
\hline$+\pi 5$ & 5 & 13 & 43 & 1 & 0 & 0 & 26 & 12 \\
\hline+53 & 6 & 13 & 45 & 1 & 0 & 0 & 20 & 15 \\
\hline+38 & 6 & 14 & 48 & 0 & 0 & 0 & 20 & 12 \\
\hline+26 & 6 & 12 & 54 & 0 & 0 & 0 & 17 & 11 \\
\hline+9 & 5 & 13 & 57 & 0 & 0 & 0 & 14 & 11 \\
\hline+1 & 0 & 0 & 0 & 0 & 0 & 0 & 0 & 0 \\
\hline ALL SIZES & 5 & 13 & 50 & 0 & 0 & 0 & 20 & 12 \\
\hline EXPECTED & 8 & 15 & 47 & 0 & 0 & 0 & 10 & 20 \\
\hline INDEX & -.38 & -.13 & .06 & no & na & no & 1.0 & -.40 \\
\hline
\end{tabular}




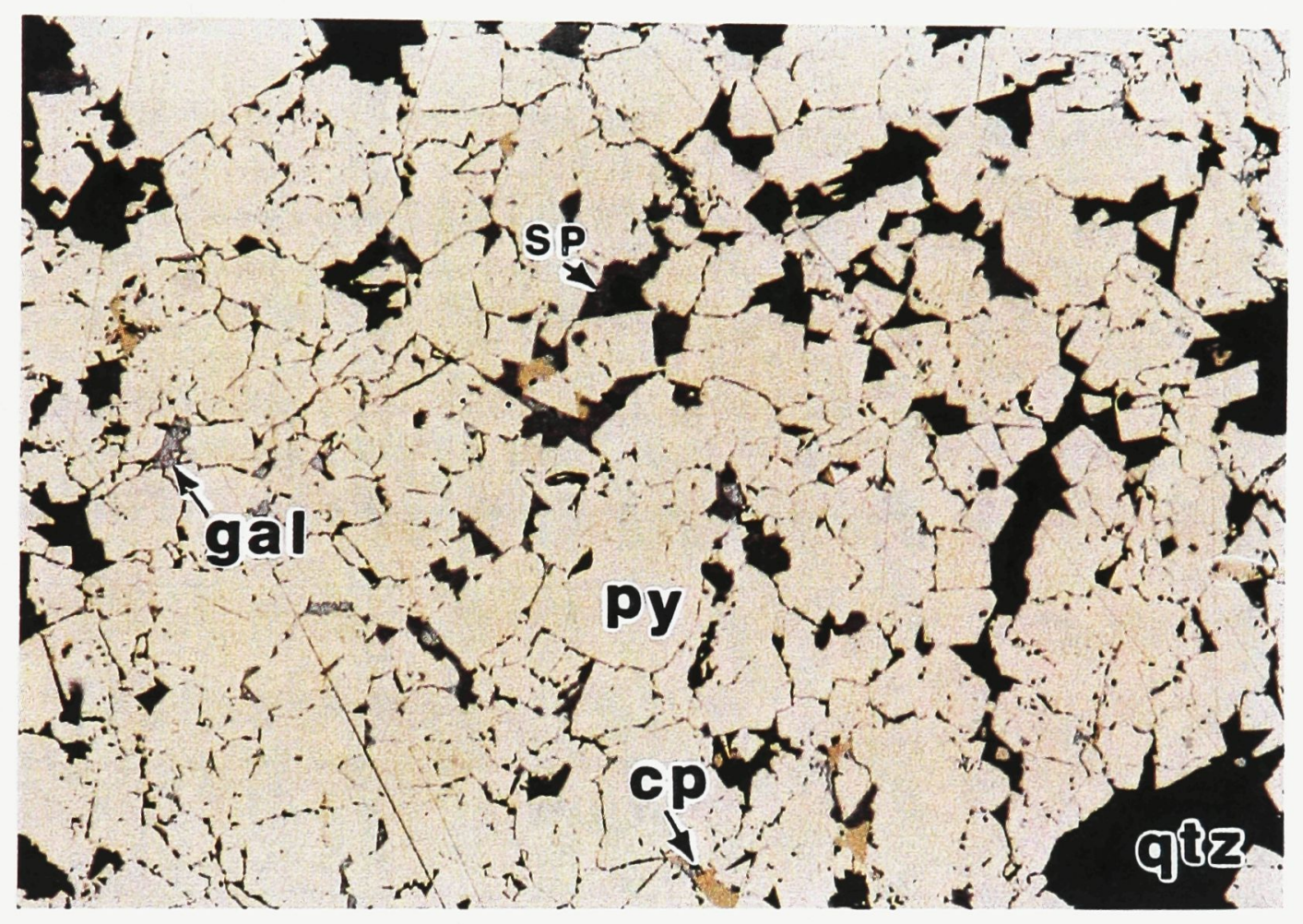

Scale:

$250 \mu \mathrm{m}$

Plate 11

Photomicrograph of $4 \mathrm{E}$ ore showing interstitial sphalerite (sp), galena (gal), chalcopyrite (cp) and quartz (qtz) in a matrix of closely-spaced pyrite grains (py). 
Fractured and brecciated pyrite grains, common in $2 \mathrm{E}$, were not observed in $4 \mathrm{E}$ ore. As well, pyrite is most often inclusion-free although occasionally it contains rounded inclusions of sphalerite, galena and quartz, particularly in the coarser pyrite grains. Cryptocrystalline pyrite was also rarely observed. Weak banding, observed by eye in some sections and defined by alternating layers of pyrite and sphalerite, is also present. Magnetite, arsenopyrite and coarse-grained marcasite are more common in $4 \mathrm{E}$ than in $2 \mathrm{E}$ ore. In $4 \mathrm{E}$ ore some sphalerite grains contain minute grains of chalcopyrite and, to a lesser extent, pyrrhotite. Pyrrhotite is found in all ore types but occurs mainly in $4 \mathrm{E}$ ore (Table 32). There it occurs as small individual grains disseminated throughout the sulphide matrix (Table 35). It often shows alteration to marcasite and pyrite. A less abundant mode of occurrence is as small blebs $(<10 \mu \mathrm{m})$ in sphalerite. Pyrrhotite, itself, commonly contains small blebs of chalcopyrite.

Chalcopyrite occurs in trace amounts as fine grains interstitial to pyrite, as veinlets in coarse pyrite grains and as ubiquitous minute grains, $<10 \mu \mathrm{m}$, in sphalerite displaying a texture suggesting exsolution. Chalcopyrite is not of economic importance in the Vangorda.

4G ORE

The most important ore facies of the Vangorda deposit is the $4 \mathrm{G}$ comprising approximately $75 \%$ of the orebody. It is gradational with the $4 \mathrm{E}$ type and together the two form all of the main horizon. Twenty two polished sections of this ore type were examined. 
The chemical and modal analyses of four combined core samples of $4 \mathrm{G}$ ore are shown in Tables 31 and 32, respectively. The grain size distributions of pyrite, sphalerite, galena, barite, arsenopyrite and magnetite are shown in Table 37 and in Figure 37 . The ore minerals pyrite, sphalerite and galena are much finer-grained than in $2 \mathrm{G}$ ore.

The associations of sphalerite and galena are shown in Table 38. The association data show that galena is most closely associated with barite (66\%) and sphalerite (23\%) but less so with pyrite (7\%). There is an indication of preferred association with the carbonates (INDEX $=3.0$ ). In particular, a significant increase in the proportion of galena associated with the carbonates is noted in the $-26+9 \mu \mathrm{m}$ size range (Figure 38). Finegrained galena is more closely associated with pyrite and quartz than coarse-grained galena.

Sphalerite is also closely associated with barite $(66 \%)$ but less so with pyrite (5\%) as in $2 \mathrm{E}$ ore. The data do not indicate an association between sphalerite and galena as strong as in $2 \mathrm{G}(24 \%)$. There is an indication of preferred association with the carbonates $($ INDEX $=4.0$ ). In particular, a significant increase in the proportion of sphalerite associated with the carbonates is noted in the $-26+9 \mu \mathrm{m}$ size range (Figure 38). As discussed in the previous chapter the association of fine-grained sphalerite and galena with siderite and ankerite is unfavourable for liberation and recovery of those minerals.

The minerals present and their textural relationships are very similar to $2 \mathrm{G}$ ore. However, $4 \mathrm{G}$ ore is much finer-grained and magnetite is more abundant than in $2 \mathrm{G}$ ore. The texture of this ore is defined by the rounded fine- to medium-grained pyrite and barite. Solution pits are common in barite in many polished sections of $4 \mathrm{G}$ ore as 
TABLE 37

GRAIN SIZE DISTRIBUTIONS FOR VANOORDA 40 ORE

(CUMULATIVE \% PASSING)

\begin{tabular}{|c|c|r|r|r|r|r|}
\hline $\begin{array}{c}\text { GRAIN } \\
\text { SIZE } \\
(\mu \mathrm{M})\end{array}$ & \multicolumn{1}{|l|}{ PY } & \multicolumn{1}{l|}{ GAL } & \multicolumn{1}{l|}{ ASP } & \multicolumn{1}{l|}{ BAR } & MAG \\
\hline 3.4 & 0.82 & 3.04 & 24.10 & 3.47 & 1.44 & 1.57 \\
\hline 4.7 & 1.18 & 4.87 & 33.69 & 6.43 & 2.21 & 2.39 \\
\hline 6.7 & 2.25 & 10.48 & 65.16 & 21.57 & 4.39 & 4.49 \\
\hline 9.4 & 4.29 & 23.15 & 78.82 & 38.04 & 9.23 & 10.08 \\
\hline 13 & 7.62 & 37.88 & 87.89 & 41.14 & 17.23 & 22.16 \\
\hline 19 & 12.36 & 52.65 & 95.03 & 54.84 & 28.27 & 37.44 \\
\hline 26 & 20.30 & 69.12 & 98.04 & 71.84 & 46.73 & 56.44 \\
\hline 38 & 30.49 & 82.06 & 99.57 & 75.48 & 67.00 & 78.74 \\
\hline 53 & 46.35 & 91.92 & 99.79 & 75.48 & 84.40 & 92.12 \\
\hline 75 & 64.79 & 96.96 & 100.00 & 100.00 & 93.43 & 97.57 \\
\hline 106 & 81.32 & 99.23 & & & 97.24 & 98.77 \\
\hline 150 & 92.00 & 100.00 & & & 98.93 & 100.00 \\
\hline 212 & 100.00 & & & & 100.00 & \\
\hline & & & & & & \\
\hline
\end{tabular}

evidence of groundwater leaching. Characteristic banding, evident to the eye in most core samples of this ore type, is defined by alternating layers and/or stringers of barite, pyrite and sphalerite (Plate 12). At microscopic scale sphalerite, galena and magnetite form in the interstices of the large pyrite and barite grains (See Plate 13). The microcrystalline variety of pyrite was also found in $4 \mathrm{G}$ ore. Fine blebs of chalcopyrite in sphalerite was not observed in $4 \mathrm{G}$ ore. 


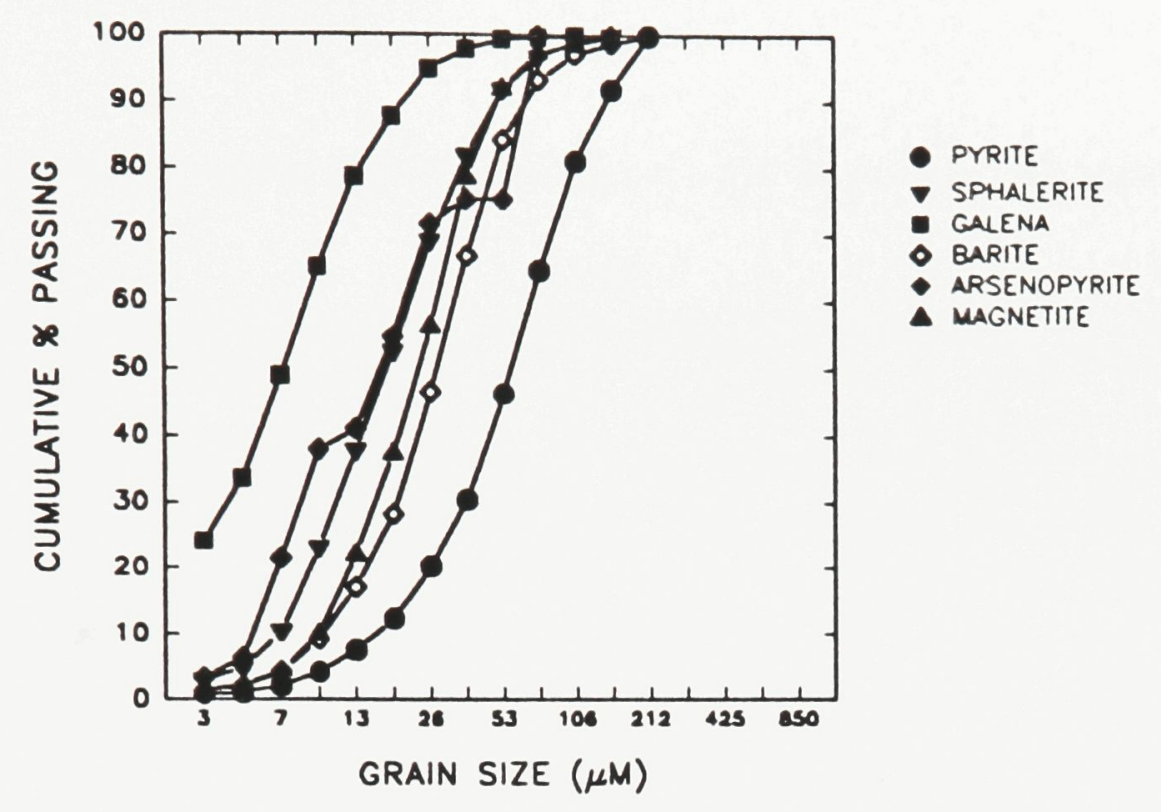

Figure 37 Grain size distributions of ore minerals in $4 \mathrm{G}$ ore.

GENERAL MINERALOGY AND GRAIN SIZE DISTRIBUTIONS OF VANGORDA ORES

Table 39 shows a comparison of the $\mathrm{K}_{80}$ sizes of the Vangorda ore types. The ore minerals are finer-grained than those of Faro ores. Compared to galena in Faro ore the galena in the Vangorda is extremely fine-grained, with a $\mathrm{K}_{80}$ ranging from $13 \mu \mathrm{m}$ to 26 $\mu \mathrm{m}$ for the three ore types with $24 \mathrm{wt} \%$ less than $3.4 \mu \mathrm{m}$ in the predominant $4 \mathrm{G}$ ore (Table 37). This fineness should result in galena losses due to locking. Sphalerite is fairly coarse-grained in all the ore types, having an average $\mathrm{K}_{80}$ of about $53 \mu \mathrm{m}$. However it is still much finer than that of Faro ore which has a $\mathrm{K}_{80}$ of less than $106 \mu \mathrm{m}$. Sphalerite is coarse enough that it should not present a problem for processing. Similarly, pyrite, the major gangue mineral, is much finer than that in Faro ore but again it should not present 
TABLE 38

MINERAL ASSOCIATIONS OF GALEMA AMD SPHALERITE IN 4 G ORE BY GRAIN SIZE (PERIMETERX)

GALEMA

\begin{tabular}{|c|c|c|c|c|c|c|c|c|}
\hline $\begin{array}{c}\text { GAL GRAIN } \\
\text { SIZE } \\
(\mu N)\end{array}$ & OTZ & $\underset{\text { ANK }}{\text { SID }}+$ & PY & $C P$ & BAR & PO & MAG & SP \\
\hline+150 & 0 & 0 & 10 & 0 & 70 & 0 & 0 & 20 \\
\hline+106 & 0 & 2 & 5 & 0 & 72 & 0 & 0 & 21 \\
\hline$+\pi$ & 0 & 1 & 6 & 0 & 68 & 0 & 1 & 24 \\
\hline+53 & 0 & 3 & 6 & 0 & 65 & 0 & 0 & 26 \\
\hline+38 & 1 & 3 & 9 & 0 & 64 & 0 & 0 & 23 \\
\hline+26 & 1 & 5 & 7 & 0 & 65 & 0 & 0 & 22 \\
\hline+9 & 1 & 9 & 7 & 0 & 55 & 0 & 0 & 28 \\
\hline+1 & 4 & 2 & 13 & 0 & 66 & 0 & 0 & 15 \\
\hline ALL SIZES & 0 & 4 & 7 & 0 & 66 & 0 & 0 & 23 \\
\hline EXPECTED & 2 & 1 & 10 & 0 & 58 & 0 & 1 & 28 \\
\hline INDEX & -1.0 & 3.0 & -.30 & na & .14 & na & -1.0 & -.18 \\
\hline
\end{tabular}

SPHALERITE

\begin{tabular}{|c|r|r|r|r|r|r|r|r|}
\hline $\begin{array}{c}\text { SP GRAIN } \\
\text { SIZE } \\
(\mu M)\end{array}$ & OTZ & $\begin{array}{c}\text { SID } \\
+\end{array}$ & \multicolumn{1}{c|}{ PY } & \multicolumn{1}{c|}{ CP } & \multicolumn{1}{c|}{ BAR } & PO & MAG & GAL \\
\hline+150 & 1 & 6 & 7 & 0 & 62 & 0 & 0 & 24 \\
\hline+106 & 1 & 3 & 4 & 0 & 70 & 0 & 0 & 22 \\
\hline+75 & 1 & 3 & 4 & 0 & 69 & 0 & 0 & 23 \\
\hline+53 & 0 & 2 & 7 & 0 & 67 & 0 & 0 & 24 \\
\hline+38 & 0 & 2 & 6 & 0 & 69 & 0 & 0 & 23 \\
\hline+26 & 0 & 4 & 6 & 0 & 68 & 0 & 0 & 22 \\
\hline+9 & 0 & 9 & 5 & 0 & 58 & 0 & 1 & 27 \\
\hline+1 & 0 & 0 & 0 & 0 & 89 & 0 & 0 & 11 \\
\hline ALL SIZES & 0 & 5 & 5 & 0 & 66 & 0 & 0 & 24 \\
\hline EXPECTED & 2 & 1 & 9 & 0 & 52 & 0 & 1 & 34 \\
\hline INDEX & -1.0 & 4.0 & -.44 & $n a$ & .27 & $n$ & -1.0 & -.29 \\
\hline
\end{tabular}




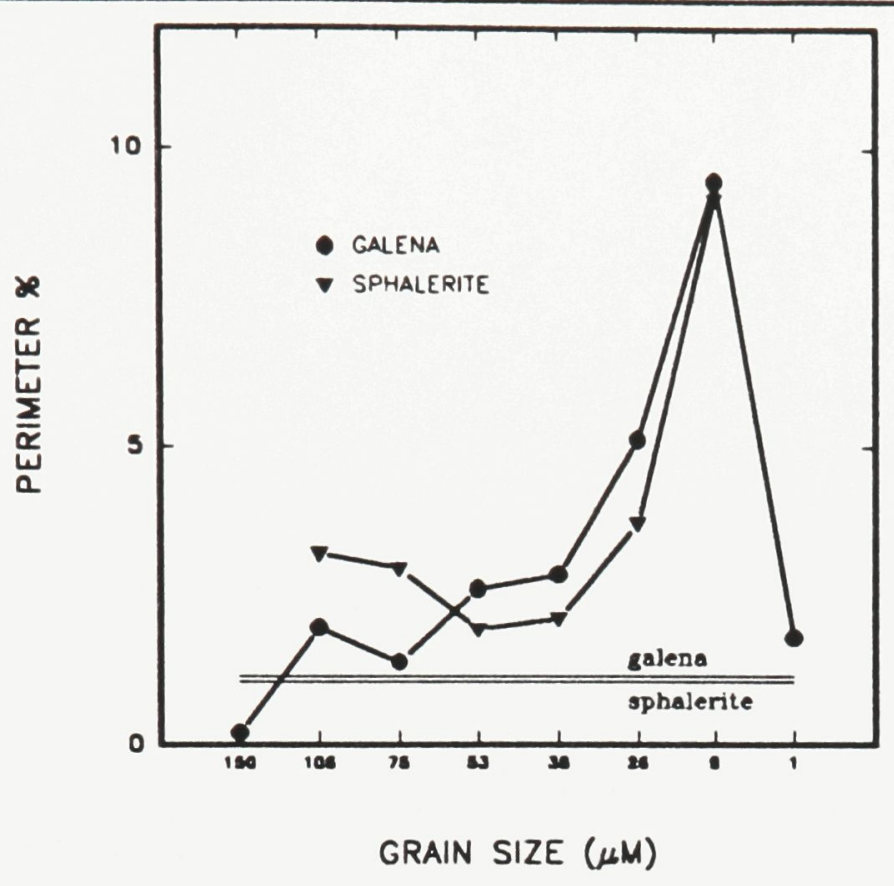

Figure 38 Associations of galena and sphalerite with carbonates by size in $4 \mathrm{G}$ ore. Flat lines show expected associations.

a liberation problem.

Porous galena, which was not seen in the Faro ores, is observed in some sections. It appears as dark-grey grains with a rough porous-like surface (Plate 14). Also secondary galena commonly appears as rims and veins on sphalerite and covellite in highlyweathered samples (Plate 15).

Marcasite occurs in all ore types mainly as an alteration product of pyrrhotite and to a much lesser extent as primary fine euhedral grains. The common textural variety is the fibrous type which is often observed replacing pyrrhotite. Occasionally it forms coarse anhedral crystals. The cryptocrystalline variety is rare in Vangorda ores.

Tetrahedrite-tennantite was identified in both the core and the concentrator products. It is more frequent in the Vangorda core samples examined than in the Faro 


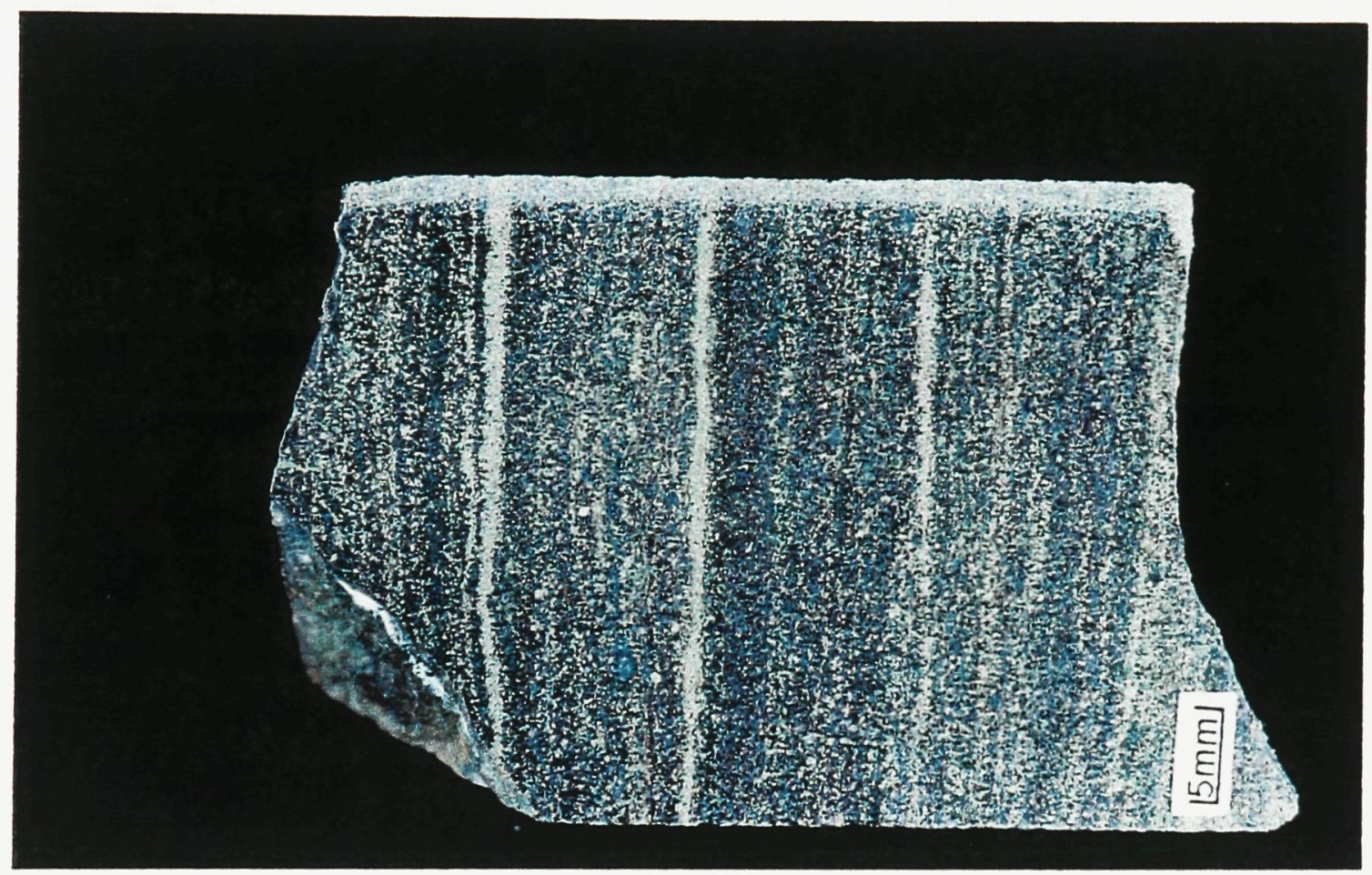

\section{Plate 12}

Photograph showing banded $4 G$ ore. Pale yellow layers of pyrite separate darker bands consisting of layers of barite (grey) and sphalerite (reddish brown). 


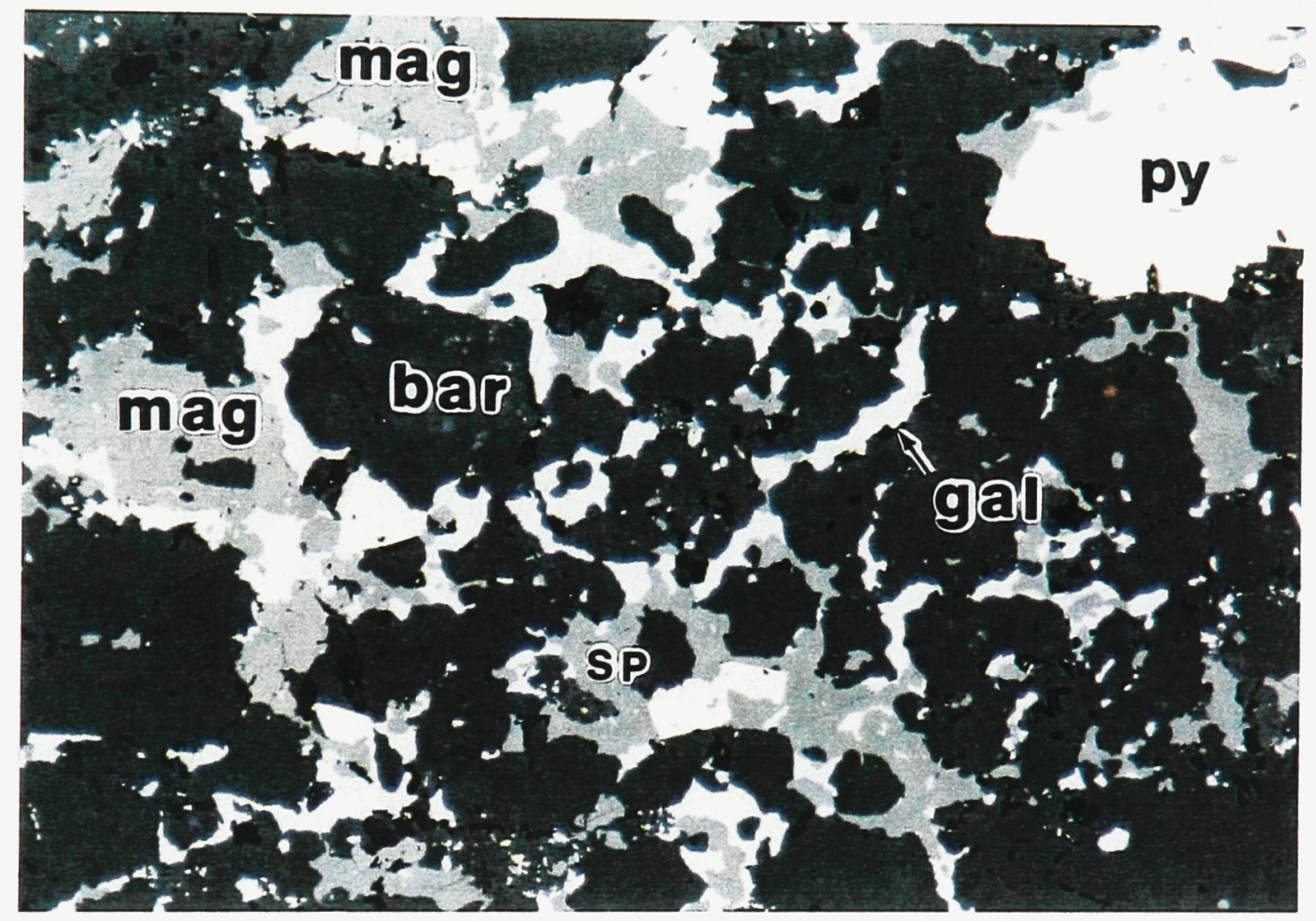

Scale:

$1 \mathrm{~mm}$

Plate 13

Photomicrograph of $4 \mathrm{G}$ ore showing the typical relationship between the large barite grains (ba) and the interstitial sphalerite (sp) and galena (gal). A few large magnetite grains (mag) are seen in the upper left of the photo and also pyrite (py). 
TABLE 39

SIZE DISTRIBUTIONS OF ORE MINERALS IN VANGORDA ORE TYPES ( $\mu$ M, 80\% PASSINO)

\begin{tabular}{|l|c|c|c|}
\hline & 4A & 4E & 40 \\
\hline Galena & 26 & 19 & 13 \\
\hline Sphalerite & 75 & 38 & 38 \\
\hline Pyrite & 75 & 75 & 106 \\
\hline
\end{tabular}

core samples. A total of 53 grains were found in the core samples. Their size ranged from 3 to $140 \mu \mathrm{m}$ with a mean size of $26 \mu \mathrm{m}$ and a $K_{80}$ of about $106 \mu \mathrm{m}$ (Table 40). Only one grain of acanthite was found in the concentrator samples and that was a free grain in the lead concentrate.

Only five grains of gold-silver alloy, which ranged in size from 16 to $40 \mu \mathrm{m}$, were found. One grain was large enough to be analyzed by electron microprobe and it contained $55 \% \mathrm{Ag}$ and $45 \% \mathrm{Au}$.

Covellite is frequently found in weathered ores (Plate 16). Also it appears as rims and patches on sphalerite grains (Plate 17) and much less often as rims on chalcopyrite (Plate 18) and galena.

Celsian, is found in trace amounts mostly associated with barite rich zones. Magnetite is present in minor amounts as coarse grains. It often has inclusions of pyrite as in the Faro ores indicating replacement of the pyrite by magnetite. Also, magnetite sometimes displays rounded inclusions of sphalerite which it appears to be replacing. Magnetite often displays a thin rim of siderite. 


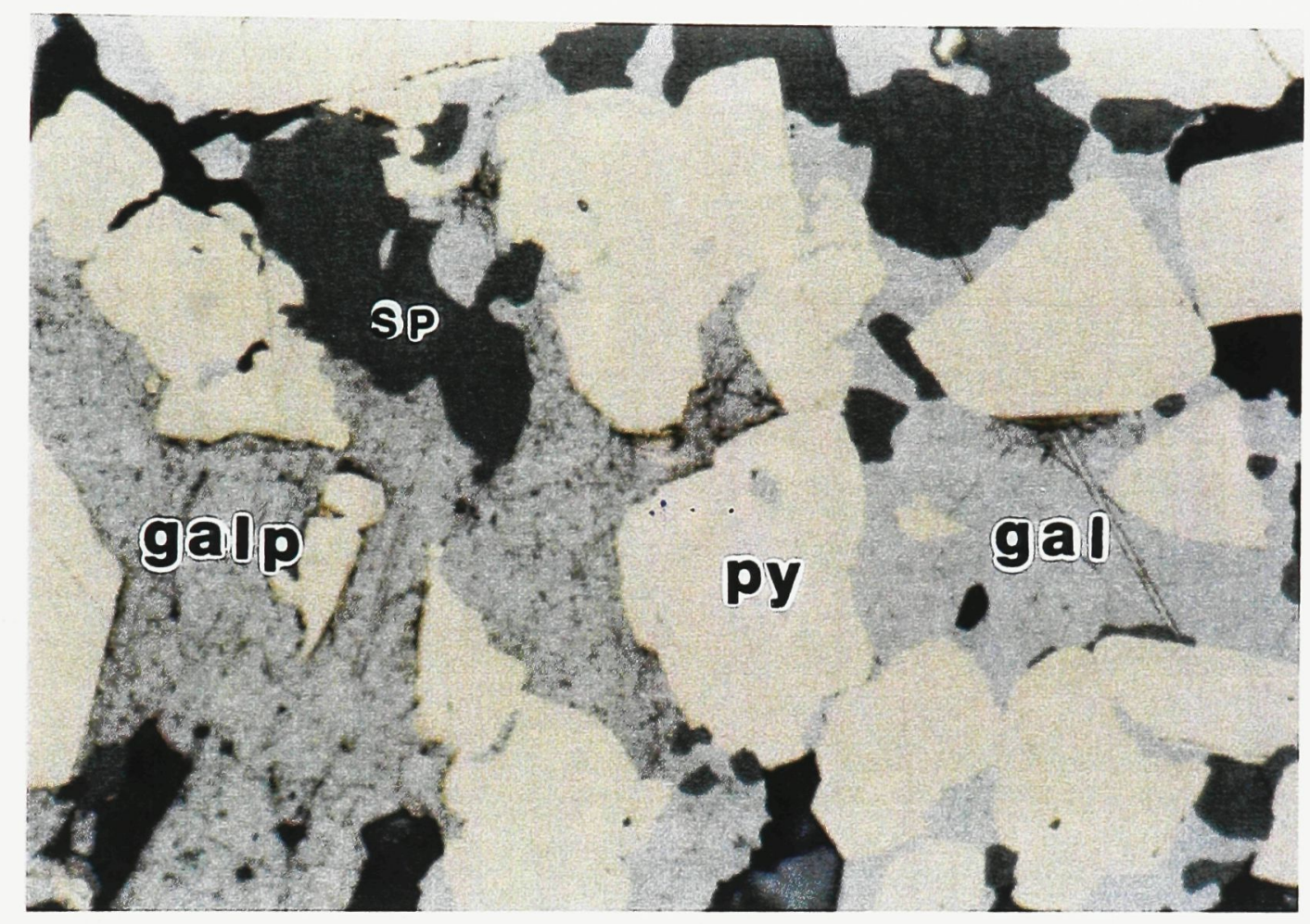

Scale: $50 \mu \mathrm{m}$

\section{Plate 14}

Photomicrograph shows normal galena (gal) on the right and porous galena (galp) on the left. Both are interstitial to pyrite (py). Also sphalerite (sp) is nearby. 


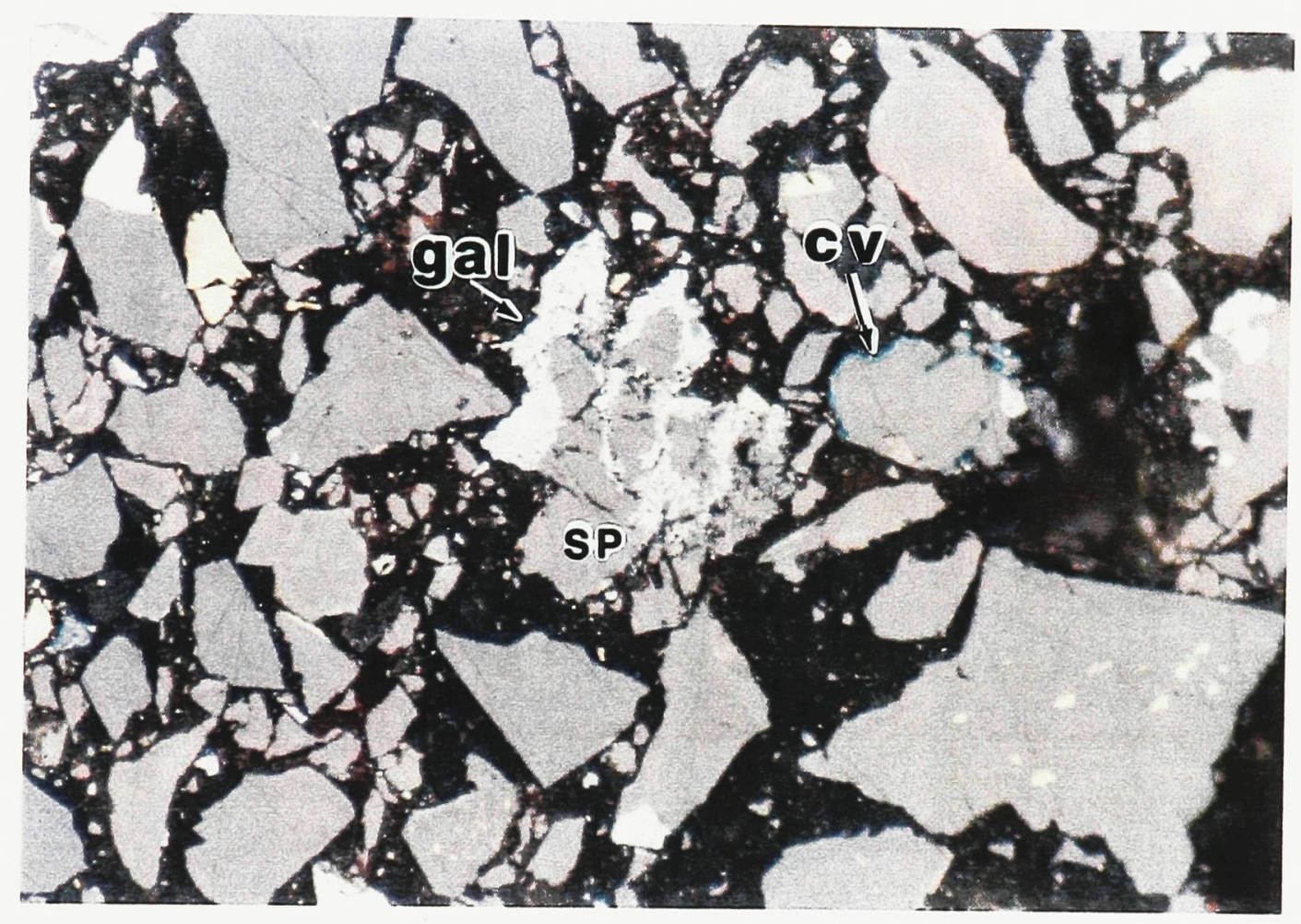

Scale: $50 \mu \mathrm{m}$

\section{Plate 15}

Photomicrograph of secondary galena (gal) forming veins and rims on a particle of sphalerite (sp) in zinc concentrate. Nearby to the right is a particle of sphalerite with a rim of covellite (cv). 
TABLE 40

SIZE DISTRIBUTION OF TETRAHEDRITE-TENNANTTTE ORAINS IN VANGORDA ORE

\begin{tabular}{|l|c|c|}
\hline $\begin{array}{c}\text { Size Interval } \\
(\mu \mathrm{M})\end{array}$ & Frequency & WT\% \\
\hline+150 & NIL & 0 \\
\hline$-150+106$ & 1 & 25 \\
\hline$-106+75$ & 2 & 29 \\
\hline$-75+38$ & 11 & 34 \\
\hline$-38+19$ & 10 & 8 \\
\hline-19 & 29 & 4 \\
\hline
\end{tabular}

Goethite is a fairly common alteration product of magnetite and the iron sulphides in Vangorda ores, especially those samples which are severely weathered.

\section{MINERAL ASSOCIATIONS OF VANGORDA ORES}

The association data show that overall galena and sphalerite tend to be associated with each other but not preferentially so as in the Faro. Galena and sphalerite are strongly associated with quartz in the quartzose $4 \mathrm{~A}$, with pyrite in pyritic $4 \mathrm{E}$ and with barite in baritic 4G. In general for the three ore types, fine-grained galena is more closely associated with pyrite and quartz than coarse-grained galena. Coarse-grained galena is more closely associated with coarse-grained sphalerite than fine-grained galena. In $4 \mathrm{G}$ ore the close association of fine-grained sphalerite and galena with the carbonates, siderite and 


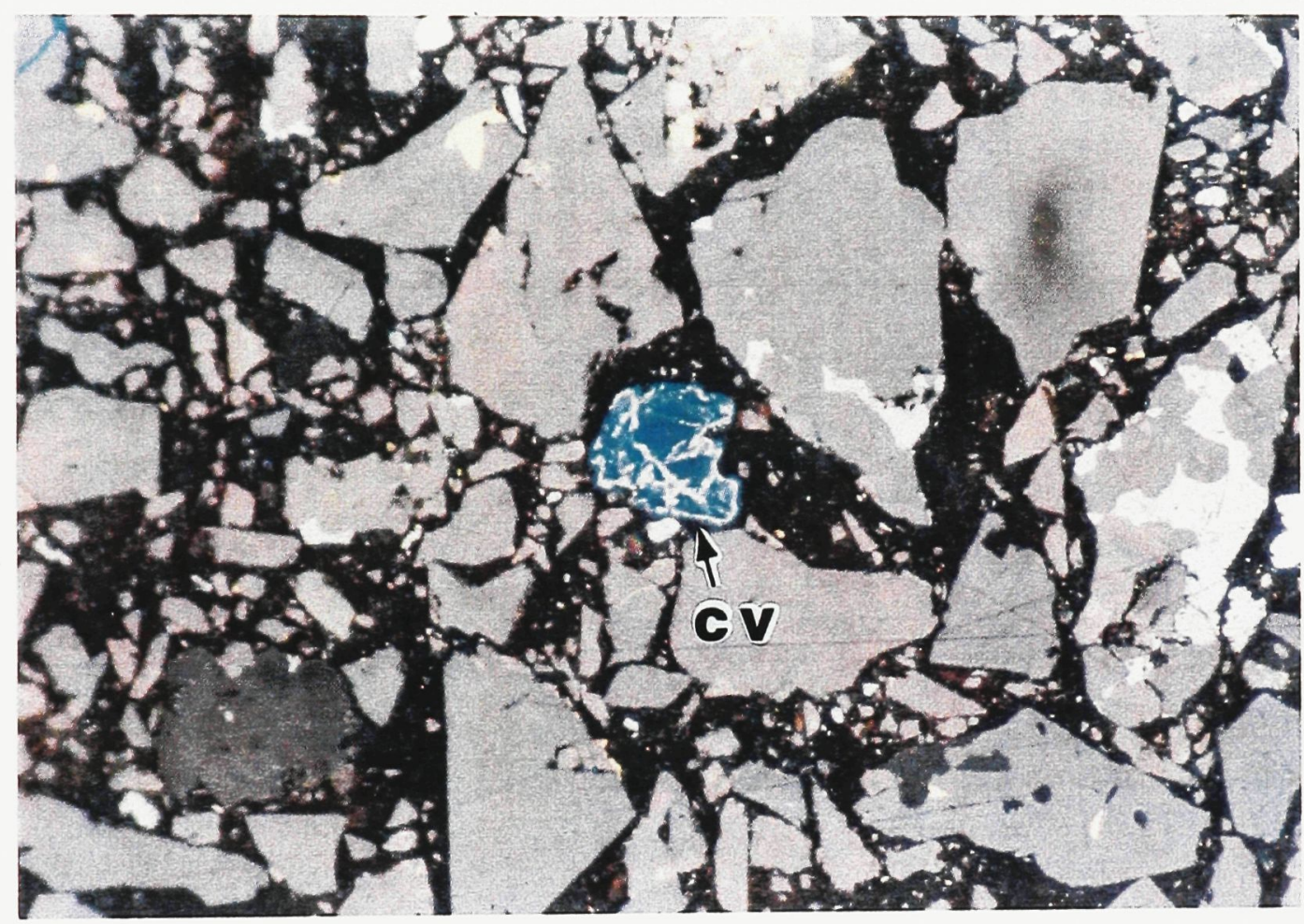

Scale:

$50 \mu \mathrm{m}$

Plate 16

Photomicrograph of a covellite-bearing particle (cv) in Vangorda zinc concentrate. White veins of secondary galena are normally associated with covellite. 


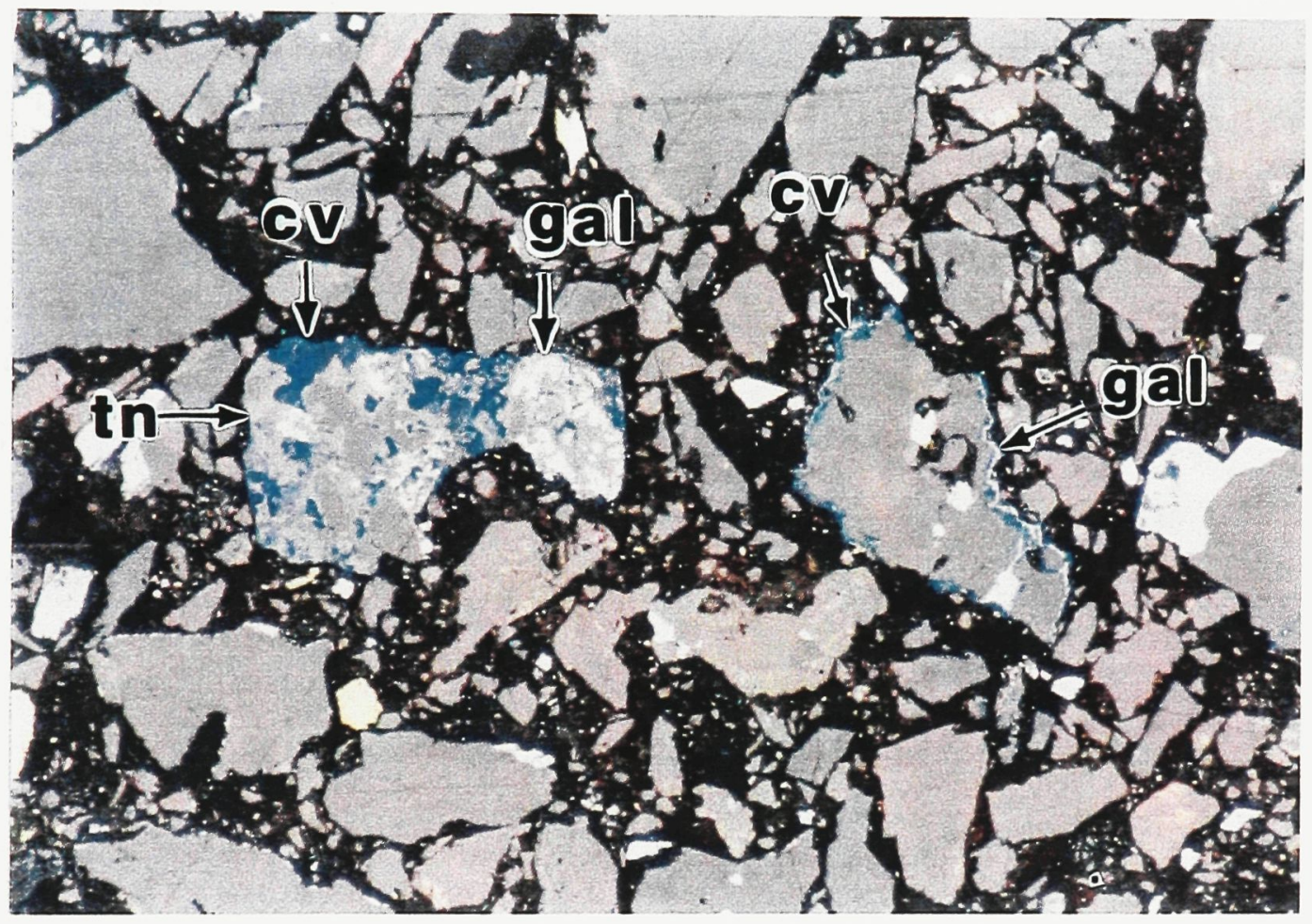

Scale:

$50 \mu \mathrm{m}$

Plate 17

Photomicrograph of Vangorda zinc concentrate showing a particle of weathered sphalerite containing covellite (cv), secondary galena (gal) and tennantite (tn). To the right is a sphalerite particle rimmed by covellite (cv) and secondary galena (gal). 


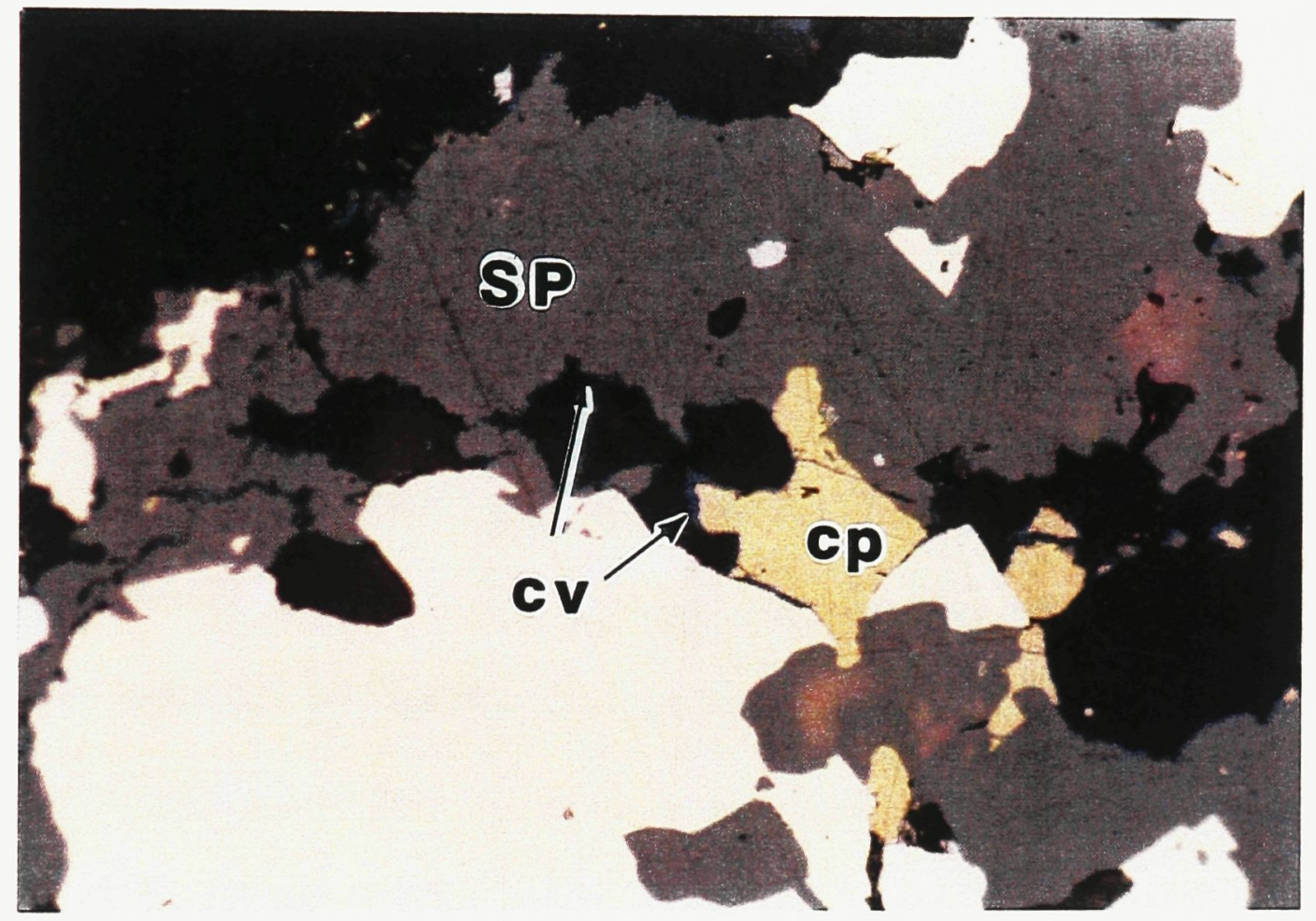

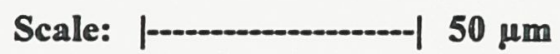

\section{Plate 18}

Photomicrograph of $4 \mathrm{G}$ ore showing chalcopyrite (cp) and sphalerite (sp) with thin rims of covellite (cv). 
ankerite, indicates a possible problem in achieving liberation, as was found in the analysis of the Faro concentrator. Galena and sphalerite have a low association with muscovite.

Tennantite is mainly associated with galena and sphalerite but has been observed associated, to a lesser extent, with chalcopyrite, pyrite and rarely with barite and carbonates. Normally the grains occur at grain boundaries and are finer-grained than those in the Faro ore.

Gold-silver is associated with chalcopyrite, sphalerite, galena and magnetite.

\section{SUMMARY}

The Vangorda ore minerals in all the ore types are much finer-grained than those of the Faro reflecting the lower grade of metamorphic environment which the Vangorda orebody was subjected to. Therefore it is expected that the recoveries of metals from Vangorda ores will be lower than for the Faro ores. One factor which should improve the grindability of the Vangorda ores is the fineness of the pyrite. It is expected the finegrained pyrite will allow breakage to proceed more easily to a finer particle size distribution than the Faro ore. This is supported by the fact that Vangorda ore has a lower Bond work index ${ }^{1}$ than Faro ore (G. McDonald pers. comm.). Furthermore, the Vangorda orebody has a large proportion of baritic ore which indicates ore liberation will be relatively easy to achieve and that there will be relatively good selectivity in flotation. The mutual association of sphalerite, galena and especially with siderite and ankerite will also be detrimental to grade and recovery.

\footnotetext{
'The Bond work index is a measure of the resistance of a material to breakage.
} 


\section{CHAPTER 7}

\section{METALLURGICAL CHARACTERISTICS OF VANGORDA ORE}

\section{INTRODUCTION}

The metallurgical characteristics of Vangorda ore are determined in the same manner as for the Faro ore. Flowsheets of the grinding circuit and the lead and zinc flotation circuits are shown in Figures 16,39 and 40. Operating parameters of the grinding mills are given in Appendix 7. Due to the fact that the size distribution of Vangorda flotation feed is approximately $80 \%$ less than $53 \mu \mathrm{m}$ the concentrator samples, except for the feed and final tailings, were not sieved before analysis.

The Vangorda ore was introduced to the concentrator for the first time about 24 hours before the sampling campaign began. Therefore it is reasonable to assume that the observed mineral behaviour is partially due to suboptimal operating conditions normally existing during startup.

\section{RESULTS AND DISCUSSION}

Grain Size Distribution of Ore Minerals in Unbroken Concentrator Feed

The ore mineral grain size distributions in the unbroken concentrator feed were measured and combined with those of the core samples of $4 \mathrm{G}$ and $4 \mathrm{E}$ ores. The results are shown in Table 41 and plotted in Figure 41. The grain size distributions for tennantite, and gold-silver are taken as those already reported in the previous chapter.

The $\mathrm{K}_{80}$ of sphalerite, galena and pyrite in the unbroken concentrator feed are $80 \%$ 


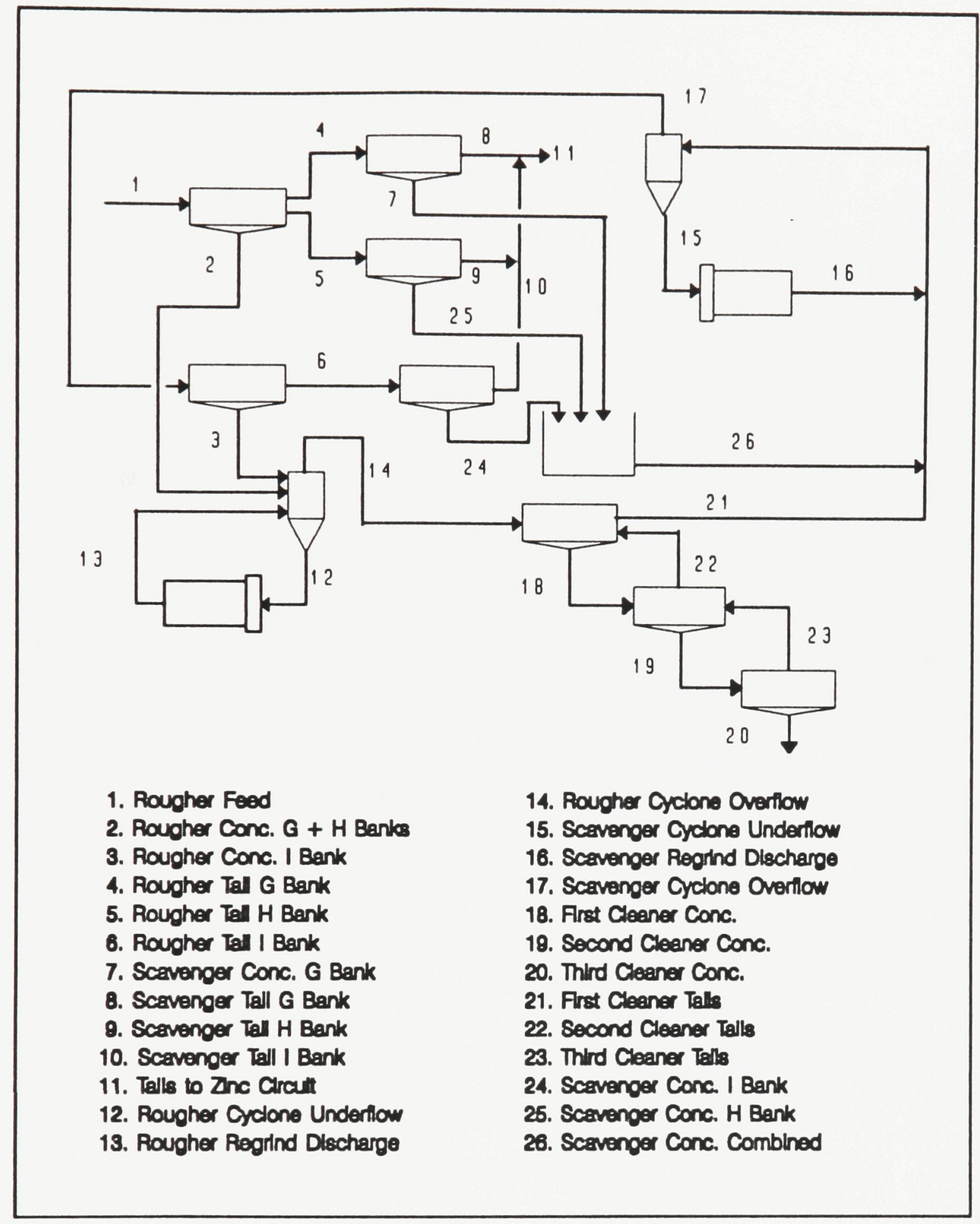

Figure 39 Vangorda lead flotation circuit. 


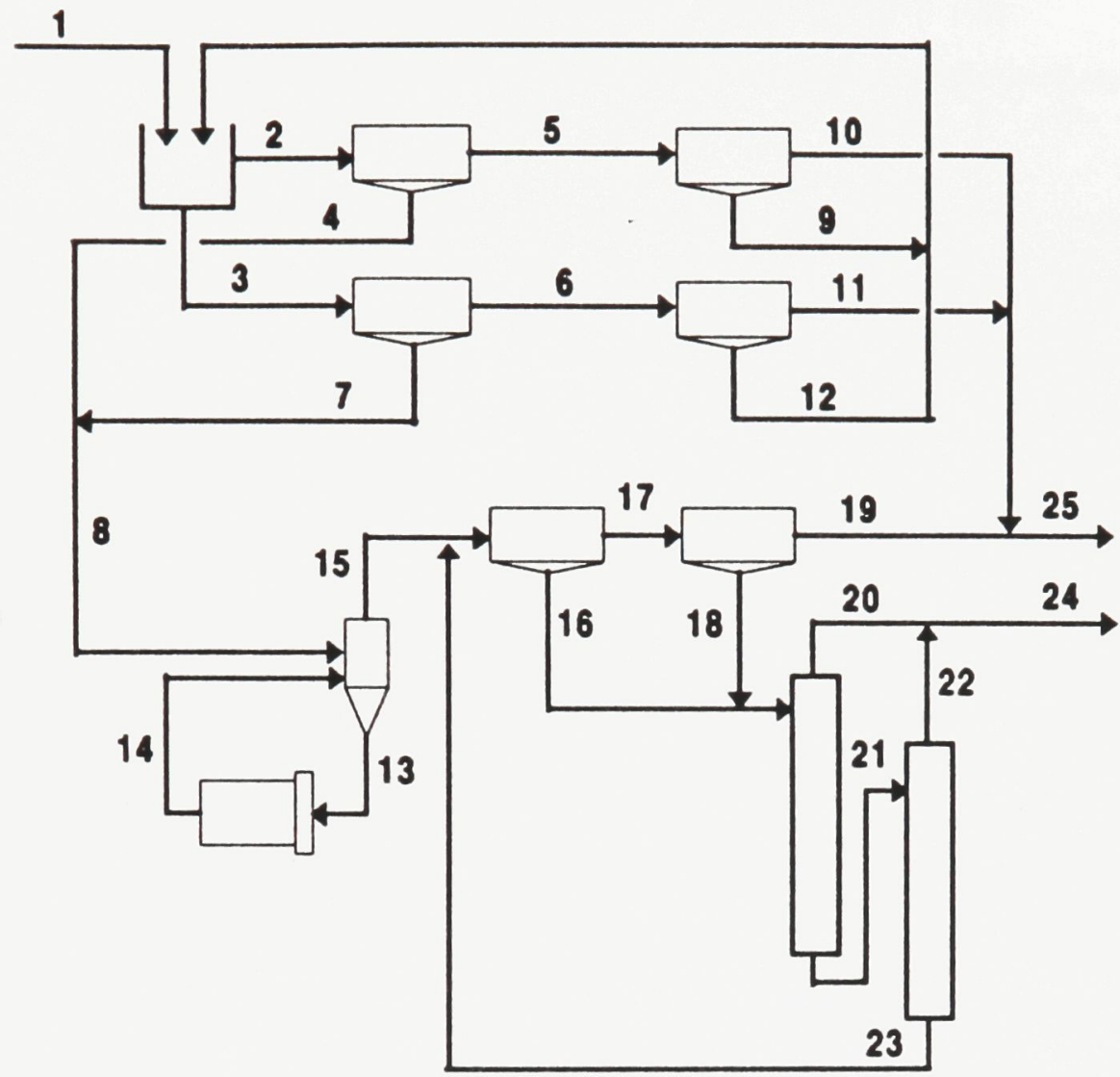

1. Feed

2. Rougher Feed $L$ Bank

3. Rougher Feed K Bank

4. Rougher Conc. L Bank

5. Rougher Tails $L$ Bank

6. Rougher Tails K Bank

7. Rougher Conc. K Bank

8. Rougher Conc. $\mathrm{K}+\mathrm{L}$

9. Scavenger Conc. L Bank

10. Scavenger Tails $L$ Bank

11. Scavenger Tails $K$ Bank

12. Scavenger Conc. K Bank

13. Regrind Cyclone Underflow
14. Regrind Discharge

15. Regrind Cyclone Overflow

16. Rougher Conc. J Bank

17. Rougher Tails J Bank

18. Scavenger Conc. J Bank

19. Scavenger Tails J Bank

20. Rougher Column Conc.

21. Rougher Column Tails

22. Scavenger Column Conc.

23. Scavenger Column Tails

24. Final Conc.

25. Final Tails

Figure 40 Vangorda zinc flotation circuit. 
TABLE 41

GRAIN SIZE DISTRIBUTIONS OF VANOORDA CONCENTRATOR FEED (CUMULATIVE \% PASSING)

\begin{tabular}{|c|c|c|c|c|c|c|c|c|}
\hline $\begin{array}{c}\text { GRAIN } \\
\text { SLZE } \\
(\mu \mathrm{M})\end{array}$ & PY & SP & GAL & BAR & QTZ & $\begin{array}{c}\text { SID } \\
+ \\
\text { ANK }\end{array}$ & CP & PO \\
\hline 3.4 & 0.67 & 2.42 & 19.47 & 0.97 & 1.85 & 0.10 & 2.32 & 3.37 \\
\hline 4.7 & 1.01 & 3.84 & 26.81 & 1.49 & 2.68 & 1.03 & 3.40 & 8.37 \\
\hline 6.7 & 2.10 & 8.28 & 48.70 & 2.97 & 5.80 & 2.48 & 8.28 & 10.76 \\
\hline 9.4 & 4.31 & 18.36 & 59.94 & 6.33 & 12.79 & 5.10 & 18.80 & 16.72 \\
\hline 13 & 8.11 & 30.07 & 68.96 & 11.88 & 22.31 & 10.43 & 31.41 & 37.59 \\
\hline 19 & 13.35 & 41.64 & 76.61 & 19.53 & 32.71 & 20.25 & 39.48 & 44.85 \\
\hline 26 & 21.22 & 55.70 & 82.56 & 32.38 & 49.47 & 35.69 & 60.71 & 59.59 \\
\hline 38 & 30.26 & 67.84 & 87.57 & 46.70 & 63.61 & 53.77 & 78.75 & 73.20 \\
\hline 53 & 41.37 & 79.59 & 93.69 & 59.71 & 77.51 & 72.59 & 93.58 & 83.28 \\
\hline 75 & 52.76 & 88.03 & 94.68 & 67.39 & 88.05 & 87.53 & 98.08 & 88.09 \\
\hline 106 & 63.35 & 94.11 & 96.68 & 71.96 & 95.18 & 96.07 & 100.00 & 92.31 \\
\hline 150 & 71.42 & 98.07 & 98.50 & 76.03 & 99.26 & 99.39 & & 96.14 \\
\hline 212 & 78.27 & 99.66 & 99.45 & 80.21 & 100.00 & 99.84 & & 98.15 \\
\hline 300 & 83.69 & 100.00 & 100.00 & 84.66 & & 100.00 & & 99.44 \\
\hline 425 & 89.03 & & & 90.29 & & & & 99.79 \\
\hline 600 & 93.72 & & & & & & & 100.00 \\
\hline 850 & 97.52 & & & & & & & \\
\hline
\end{tabular}

passing $53 \mu \mathrm{m}, 23 \mu \mathrm{m}$ and $212 \mu \mathrm{m}$, respectively (Table 41 ). These data may be compared with the actual grinds achieved shown in Table 42 . The data in Table 42 show $86 \%$ passing $53 \mu \mathrm{m}$ in the plant feed which indicates that pyrite should be well liberated (Petruk 1986). The lead rougher cyclone overflow is $81 \%$ passing $19 \mu \mathrm{m}$ thus, for galena the grind is about the same as the grain size distribution indicating liberation may not be good. The size distribution of the zinc regrind overflow is $82.7 \%$ passing $26 \mu \mathrm{m}$ indicating that sphalerite will be well liberated. The $\mathrm{K}_{\mathbf{8 0}}$ for tennantite is estimated to be 


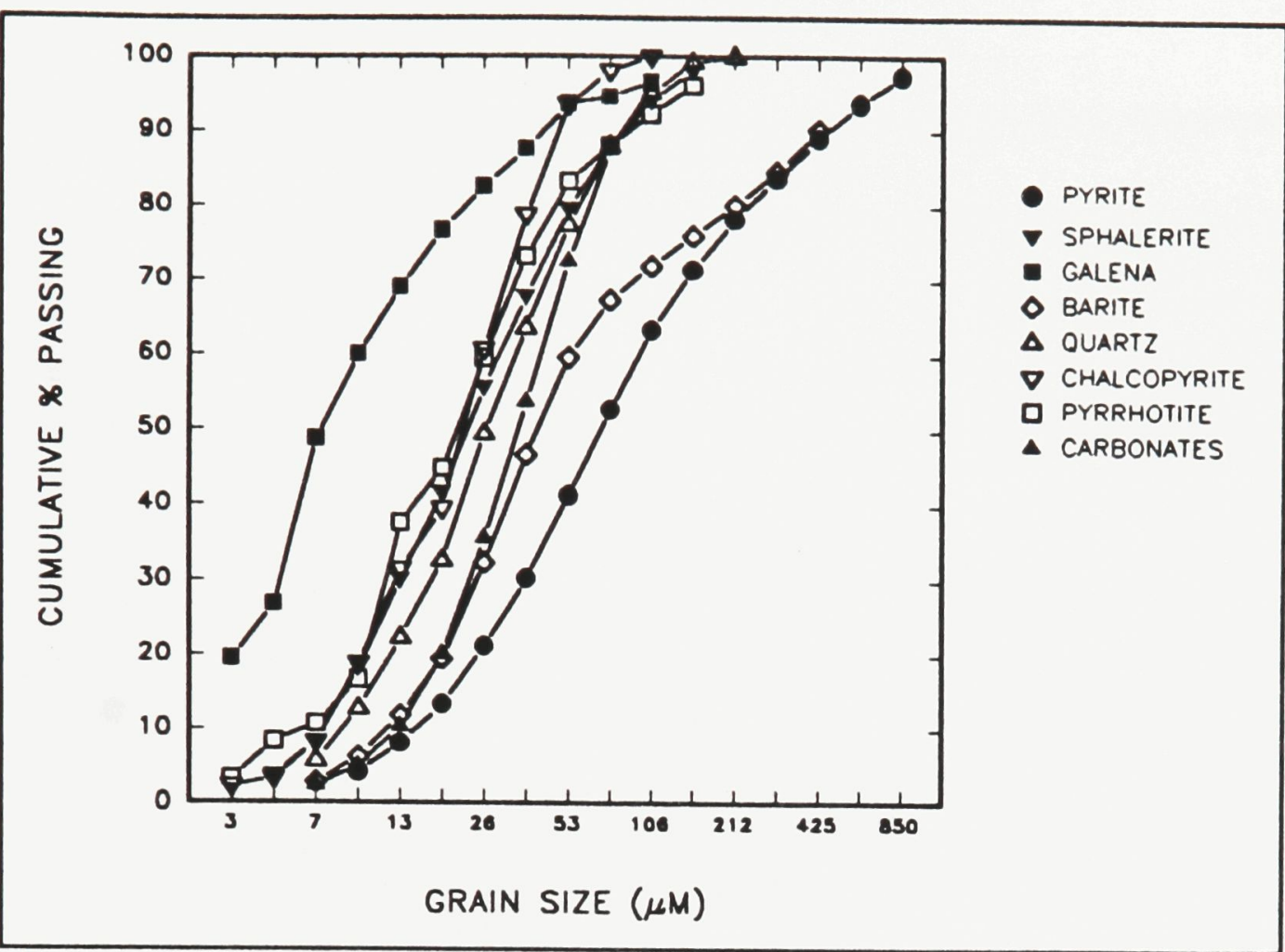

Figure 41 Grain size distributions of ore minerals in Vangorda concentrator feed.

$100 \mu \mathrm{m}$ and for gold-silver about $40 \mu \mathrm{m}$, which shows that both minerals should be well liberated.

Metal and Mineral Quantities and Recoveries

The balanced solid flowrates, in TPH, calculated by the materials balance program, BILMAT, are given in Appendix 18. Measured and balanced assays and recoveries for lead, zinc, silver, antimony, copper and gold in each stream are given in Appendix 19 for each circuit. The balanced quantities of the major and minor minerals in each stream are given in Appendix 20. 


\section{TABLE 42}

PARTICLE SIZE DISTRIBUTIONS OF SELECTED STREAMS IN VANGORDA CONCENTRATOR* (CUMULATIVE \% PASSING)

\begin{tabular}{|c|c|c|c|c|c|c|}
\hline $\begin{array}{c}\text { GRAIN } \\
\text { SIZE } \\
(\mu \mathrm{M})\end{array}$ & FEED & $\begin{array}{c}\text { LEAD } \\
\text { RO CYC } \\
\text { O/F }\end{array}$ & $\begin{array}{c}\text { LEAD } \\
\text { CONC. }\end{array}$ & $\begin{array}{c}\text { ZINC } \\
\text { RO CYC } \\
\text { O/F }\end{array}$ & $\begin{array}{c}\text { ZINC } \\
\text { CONC. }\end{array}$ & $\begin{array}{c}\text { FINAL } \\
\text { TAILS }\end{array}$ \\
\hline 9.4 & 33.93 & 53.20 & 51.91 & 50.37 & 46.07 & 32.11 \\
\hline 13 & 40.89 & 64.23 & 63.27 & 58.31 & 56.78 & 38.76 \\
\hline 19 & 51.52 & 81.20 & 80.76 & 70.99 & 73.11 & 48.98 \\
\hline 26 & 61.98 & 93.40 & 94.44 & 82.71 & 87.10 & 58.11 \\
\hline 38 & 72.11 & 95.44 & 98.81 & 83.92 & 92.27 & 66.28 \\
\hline 53 & 86.08 & & 99.85 & & 98.49 & 81.20 \\
\hline 75 & 93.73 & & 100.00 & & 99.74 & 89.49 \\
\hline 106 & 97.37 & & & & 100.00 & 94.77 \\
\hline
\end{tabular}

From combined sieve and cyclosizer data

Liberation and Distributions of Sphalerite and Galena in the Lead Flotation Circuit The liberation of sphalerite and galena was measured in all the concentrator samples and the data were balanced for each circuit and are shown in TPH in Table 43.

Rougher-scavenger flotation $\mathrm{G}+\mathrm{H}$ banks

The rougher cells recover only $60 \%$ of the galena and $13 \%$ of the sphalerite (Figure 42 and 43). The galena reporting to the rougher tails amounts to $4.8 \mathrm{TPH}$ of which about $50 \%$ is "liberated" (Figure 44). The sphalerite distributed to the rougher concentrate amounts to 5.5 TPH of which $77 \%$ is "liberated".

The scavenger cells recover $34 \%$ of the galena in the rougher tails which results in a combined rougher-scavenger galena recovery of $74 \%$ (Figure 42 ). The remaining $26 \%$ of the galena which is lost to the scavenger tails is $41 \%$ "liberated" (Figure 44). The 
TABLE 43

LIBERATION OF GALENA AND SPHALERITE IN THE VANGORDA CONCENTRATOR (TPH)

LEAD CIRCUIT

Rougher feed

Rougher conc. gth

Rougher conc. i

Rougher tail gth

Scavenger conc. i

Rougher tail i

Scavenger conc. $g+h$

Scavenger tail $g+h$

Scavenger tail i

Tails

Cyclone underflow

Regrind discharge

Cyclone overflow

Scavenger cyc. u/flow

Scavenger reg. disch.

Scavenger cyc. olflow

First cleaner conc.

Second cleaner conc.

Third cleaner conc.

First cleaner tail

Second cleaner tail

Third cleaner tail
Liberated
Galena

18.25

13.41

3.27

4.84

6.75

7.50

2.19

2.64

0.75

3.40

64.90

63.77

15.55

17.27

16.63

10.77

19.71

31.98

13.08

2.47

6.63

18.90
Middl ing

\subsection{4}

0.77

1.02

2.57

2.95

3.29

0.75

1.82

0.35

2.16

11.68

12.79

2.89

2.87

2.38

4.31

3.71

5.85

1.78

1.11

1.99

4.07
Tailing
Galena

2.87

0.52

0.38

2.34

1.18

1.40

0.41

1.94

0.23

2.18

3.27

3.20

0.89

1.61

1.14

1.78

1.18

1.35

0.21

0.67

0.94

1.13
Liberated Middling Tailino
Sphal. Sphal. Sphal.

37.37

4.00

2.07

$\begin{array}{lll}4.18 & 1.02 & 0.25\end{array}$

$\begin{array}{lll}3.68 & 0.55 & 0.06\end{array}$

$\begin{array}{lll}33.18 & 2.98 & 1.79\end{array}$

$\begin{array}{lll}13.70 & 1.80 & 0.14\end{array}$

$\begin{array}{lll}17.73 & 2.94 & 0.30\end{array}$

$\begin{array}{lll}1.94 & 0.39 & 0.05\end{array}$

$\begin{array}{lll}31.24 & 2.60 & 1.77\end{array}$

$\begin{array}{lll}4.03 & 1.14 & 0.15\end{array}$

$\begin{array}{lll}35.27 & 3.74 & 1.91\end{array}$

$\begin{array}{lll}27.69 & 8.43 & 0.99\end{array}$

$28.22 \quad 8.03 \quad 0.83$

$\begin{array}{lll}8.40 & 1.17 & 0.18\end{array}$

$\begin{array}{lll}14.50 & 2.49 & 0.42\end{array}$

$\begin{array}{lll}13.97 & 3.01 & 0.44\end{array}$

$\begin{array}{lll}21.41 & 3.50 & 0.34\end{array}$

$\begin{array}{lll}9.67 & 1.42 & 0.10\end{array}$

$\begin{array}{lll}13.45 & 2.87 & 0.26\end{array}$

$\begin{array}{lll}2.10 & 0.38 & 0.03\end{array}$

$\begin{array}{lll}6.30 & 0.79 & 0.14\end{array}$

$\begin{array}{lll}7.57 & 1.04 & 0.07\end{array}$

$\begin{array}{lll}11.35 & 2.48 & 0.21\end{array}$

ZINC CIRCUIT

Feed

Rougher feed $l+k$

Rougher conc. $1+k$

Rougher tail $l+k$

Scavenger conc. $1+k$

Scavenger tail $1+k$

Regrind cyc. underflow

Regrind discharge

Regrind cyc. overflow

Rougher concentrate j

Rougher tail j

Scavenger concentrate j

Scavenger tail j

Rougher column conc.

Rougher colum tail

Scavenger colum conc.

Scavenger colum tail

Zinc concentrate

Final tail
Tailing

Galena

\begin{abstract}
iberated
Galena
\end{abstract}
3.18

3.85

1.76

2.09

0.67

1.42

6.97

7.66

2.46

7.14

4.27

3.32

0.94

1.09

9.37

0.42

8.96

1.51

2.37
2.58

2.36

2.70

1.84

0.86

0.34

0.52

5.52

4.32

0.64

2.19

0.94

0.70

0.24

0.33

2.57

0.08

2.49

0.40

0.76
3.26

1.42

1.84

0.68

1.16

3.96

3.14

0.61

1.47

1.01

0.66

0.35

0.19

1.94

0.07

1.88

0.26

1.50
Liberated Middling Tailing
Sphal.

33.57

37.95

31.04

6.90

4.38

2.52

103.75

113.01

40.30

103.15

28.03

24.91

3.12

25.36

102.71

11.82

90.89

37.18

5.64
5.48

6.61

5.06

1.55

1.12

0.43

12.73

9.17

1.50

5.84

2.20

1.44

0.75

0.51

6.77

0.24

6.54

0.75

1.18
2.26

3.18

1.28

1.89

0.91

0.98

2.72

1.84

0.41

1.24

0.81

0.49

0.32

0.06

1.67

0.03

1.64

0.09
1.30 


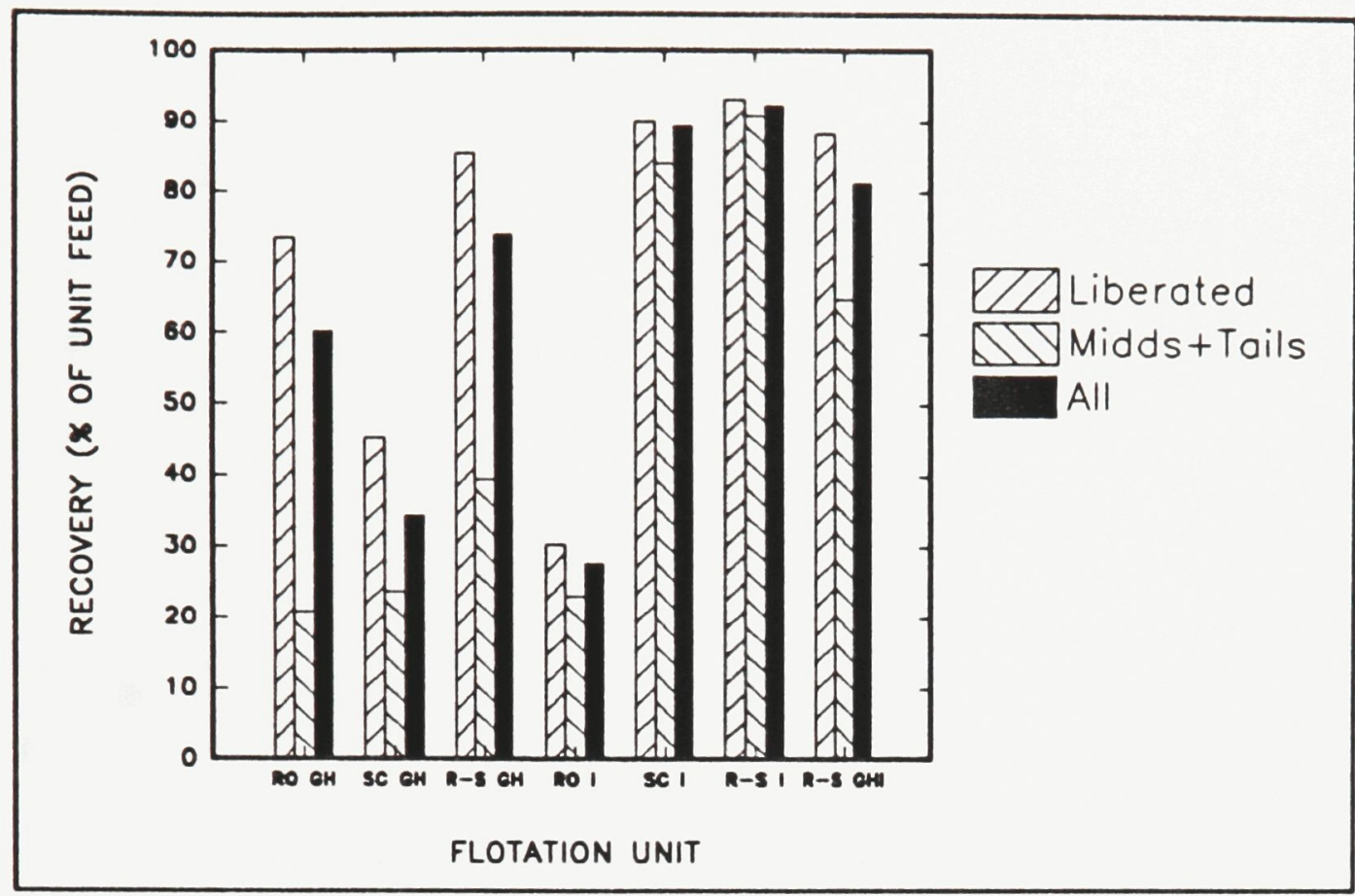

Figure 42 Galena recovery by liberation class in Vangorda lead circuit.

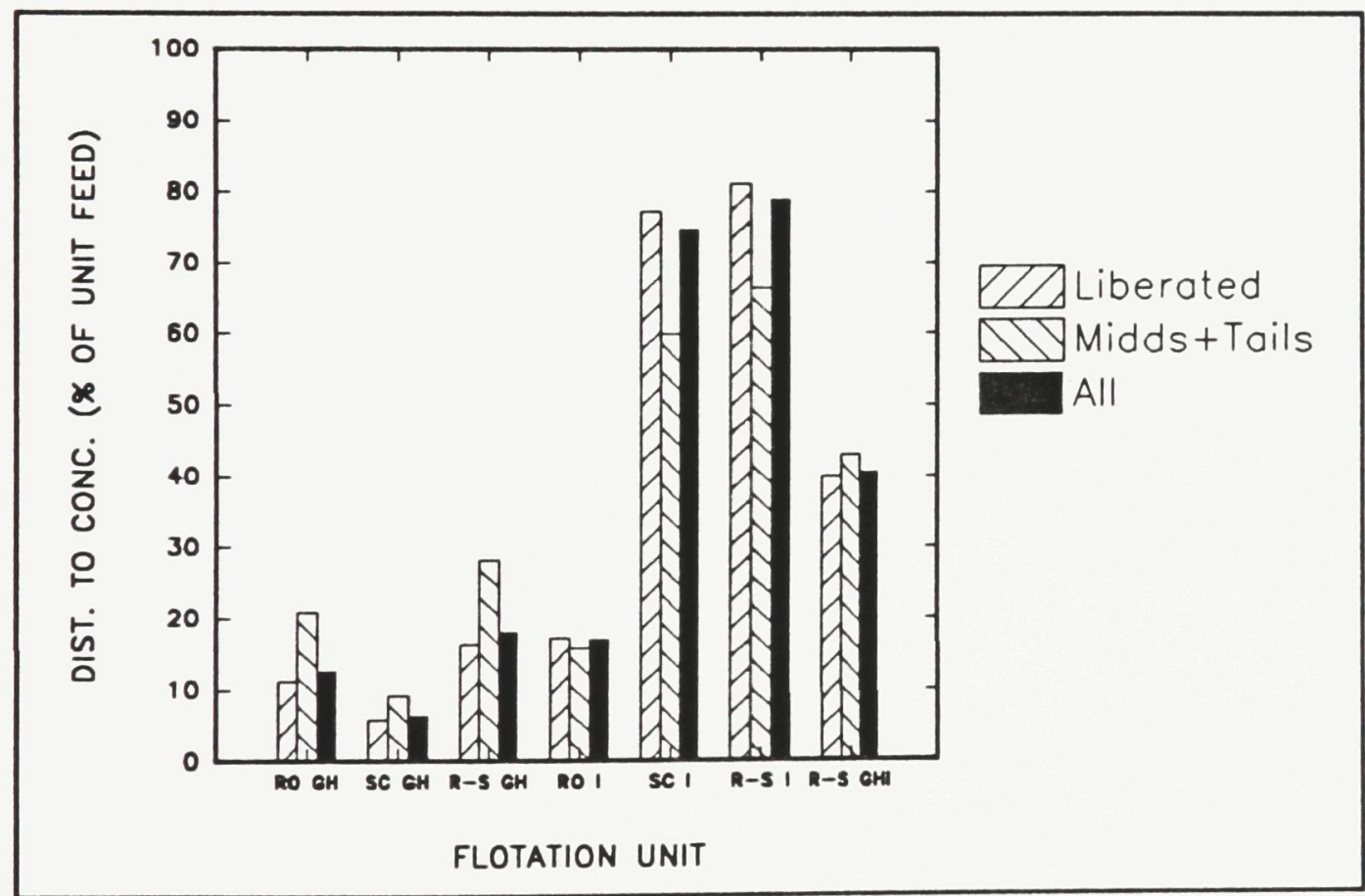

Figure 43 Sphalerite distribution by liberation class in Vangorda lead circuit. 


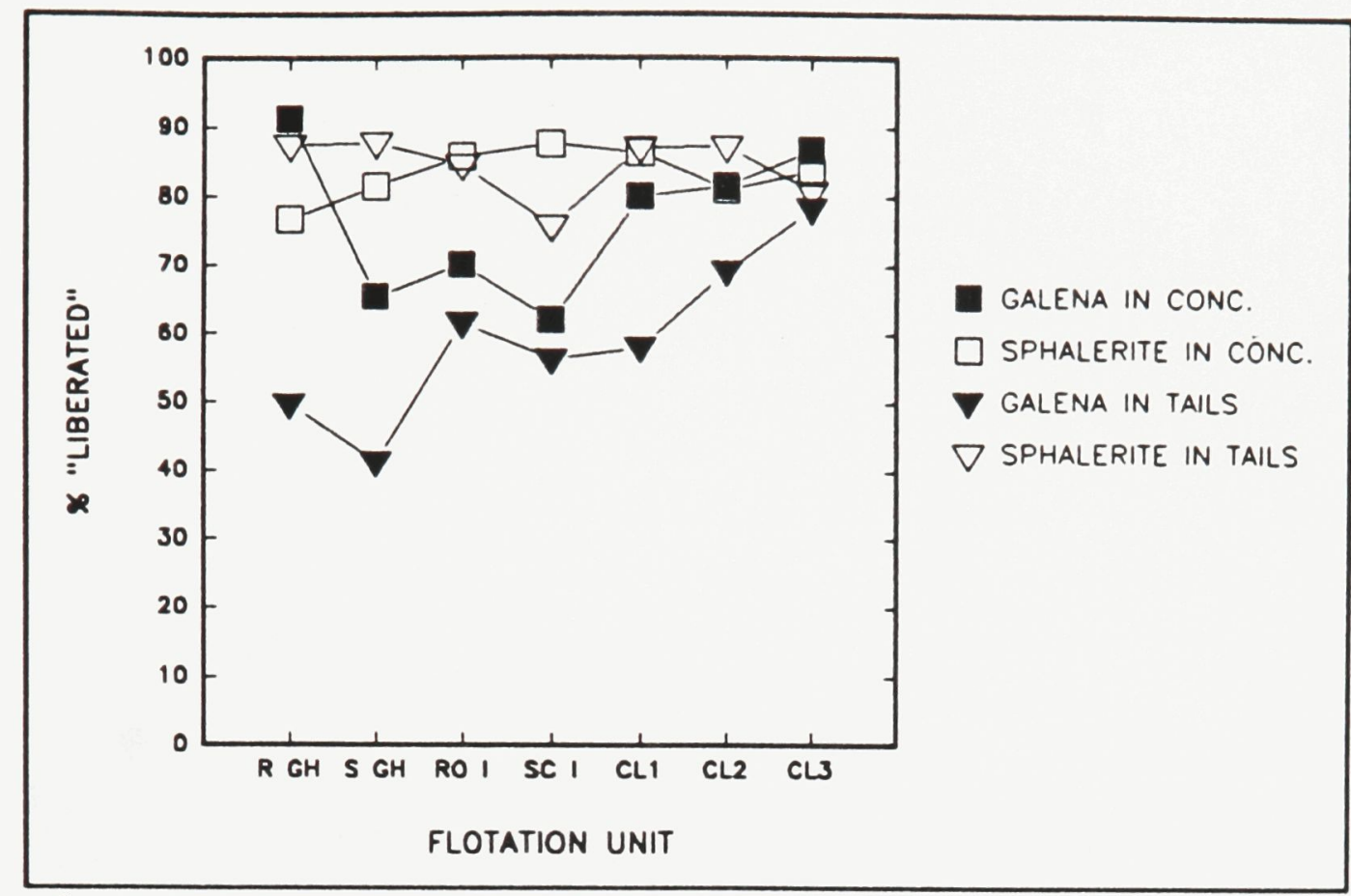

Figure 44 Percent "liberated" in flotation streams of Vangorda lead circuit.

scavengers distribute $6 \%$ of the sphalerite in the rougher tails to the scavenger concentrate (Figure 43).

It is concluded that the rougher-scavenger flotation bank is recovering only $74 \%$ of the galena due to the loss of a significant amount of "liberated" and middling galena in the scavenger tailings.

Rougher-scavenger flotation I bank

The purpose of the I bank flotation cells is to recover galena from freshly reground middlings in the scavenger regrind cyclone overflow (SCOF). The feed (SCOF) consists of $15 \%$ galena of which $64 \%$ is "liberated" and $22 \%$ sphalerite of which $85 \%$ is "liberated" (Figure 45).

The I bank rougher recovers only $27 \%$ of the galena (Figure 42 ). The galena in 


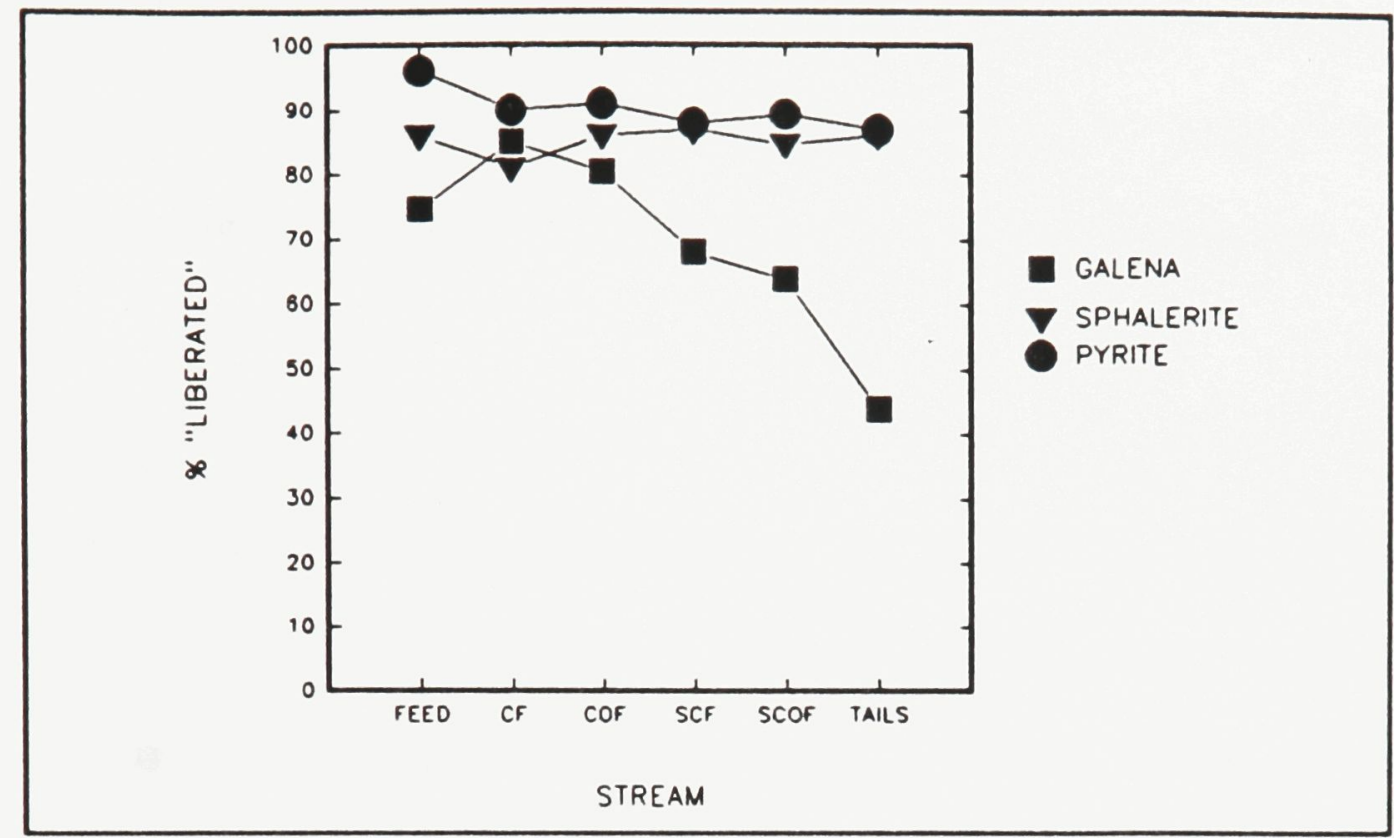

Figure 45 Percent "liberated" in selected streams of Vangorda lead circuit.

the rougher concentrate is $70 \%$ "liberated" while that in the tails is $62 \%$ "liberated" (Figure 44). Therefore the low recovery is not due to inadequate liberation of galena. The I bank scavenger recovers $89 \%$ of the galena in the rougher tails (Figure 42 ). The galena in the scavenger concentrate is $62 \%$ "liberated" whereas that in the scavenger tail is $56 \%$ "liberated" (Figure 44). The slow flotation response of galena is demonstrated by the large difference in galena recovery between the rougher and scavenger cells (Figure 42). The I bank rougher-scavenger unit is distributing a significant proportion of "liberated" sphalerite to the two lead concentrates.

Taking the rougher-scavengers of the $\mathrm{G}, \mathrm{H}$ and I banks together, the galena recovery is $81 \%$ (Figure 42 ). The galena lost to tails is $44 \%$ "liberated" (Figure 45 ). The overall sphalerite distribution to concentrates is $40 \%$ (Figure 43) of which most is "liberated" (Figure 44). Two thirds of this sphalerite is floated by the I bank scavenger. This indicates poor selectivity for sphalerite in the I bank scavenger. 
It is concluded that a considerable amount of "liberated" and middling galena is lost to tailings. Also, a large proportion of "liberated" sphalerite is recovered in the I bank scavenger concentrate. The causes for this poor selectivity are discussed later.

Rougher hydrocyclone - regrind ball mill

The hydrocyclone distributes to the underflow (CUF) $81 \%$ of the galena in the cyclone feed (Figure 46). The distributions of galena to the underflow for the "liberated", middling and tailing classes are $81 \%, 80 \%$ and $80 \%$, respectively. Galena "liberation" is $85 \%$ in the rougher cyclone feed (CF) and $81 \%$ in the cyclone overflow (COF) indicating, within experimental error, no measurable increase in the "liberated" class of galena (Figure 45).

Sphalerite distribution to the cyclone underflow is $79 \%$ of the sphalerite in the cyclone feed (Figure 46). Sphalerite distributions to the underflow for the "liberated", middling and tailings classes are $77 \%, 88 \%$ and $87 \%$, respectively. Sphalerite "liberation" increases from $81 \%$ to $86 \%$ across the regrind circuit (Figure 45 ).

A negligible increase in "liberation" of pyrite is observed (Figure 45).

Scavenger hydrocyclone - regrind ball mill

The hydrocyclone distributes to the underflow $56 \%$ of the galena in the cyclone feed (Figure 47). The galena distributions for the "liberated", middling and tailing classes are $62 \%, 55 \%$ and $47 \%$, respectively. Galena "liberation" is $68 \%$ in the regrind circuit feed (SCF) and $64 \%$ in the product (SCOF), indicating no increase in liberation (Figure 


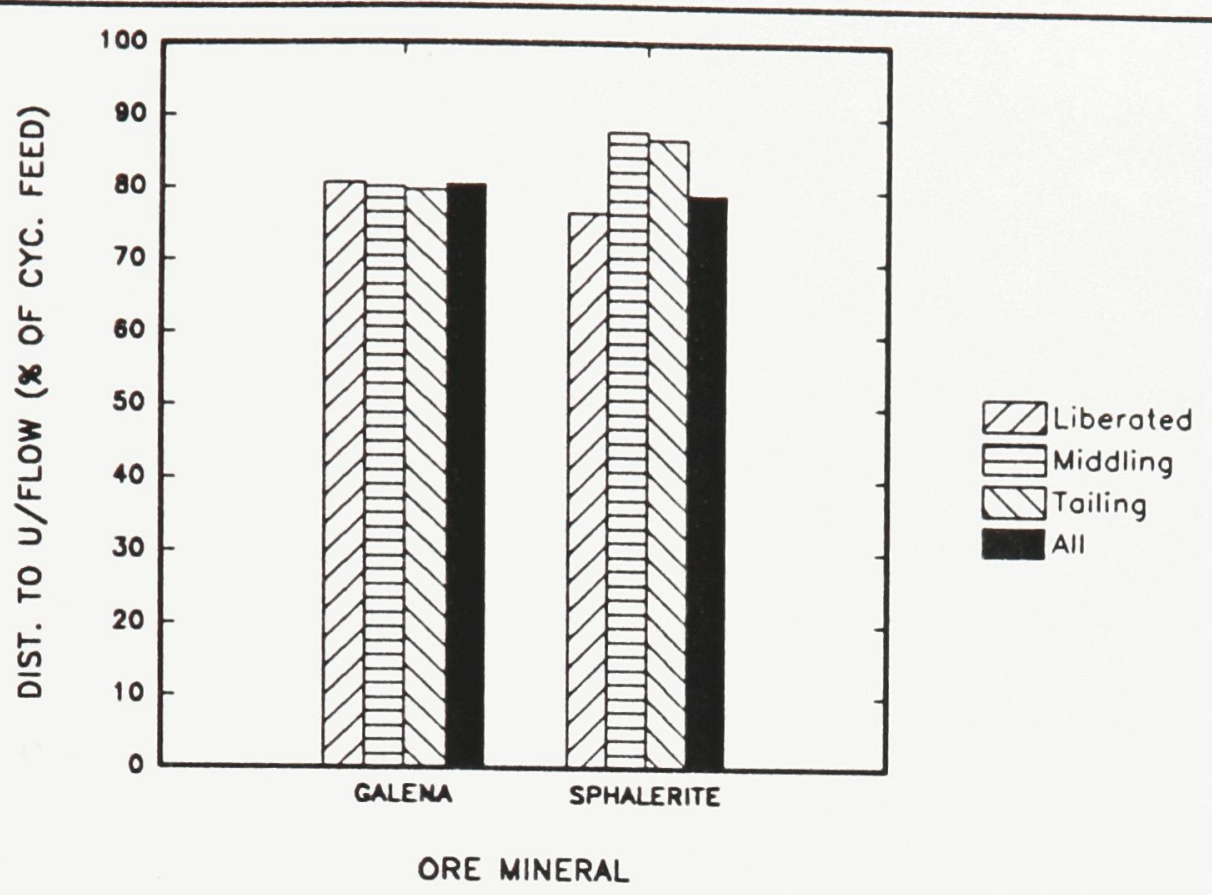

Figure 46 Galena and sphalerite distribution by liberation class to Vangorda lead rougher regrind cyclone underflow.

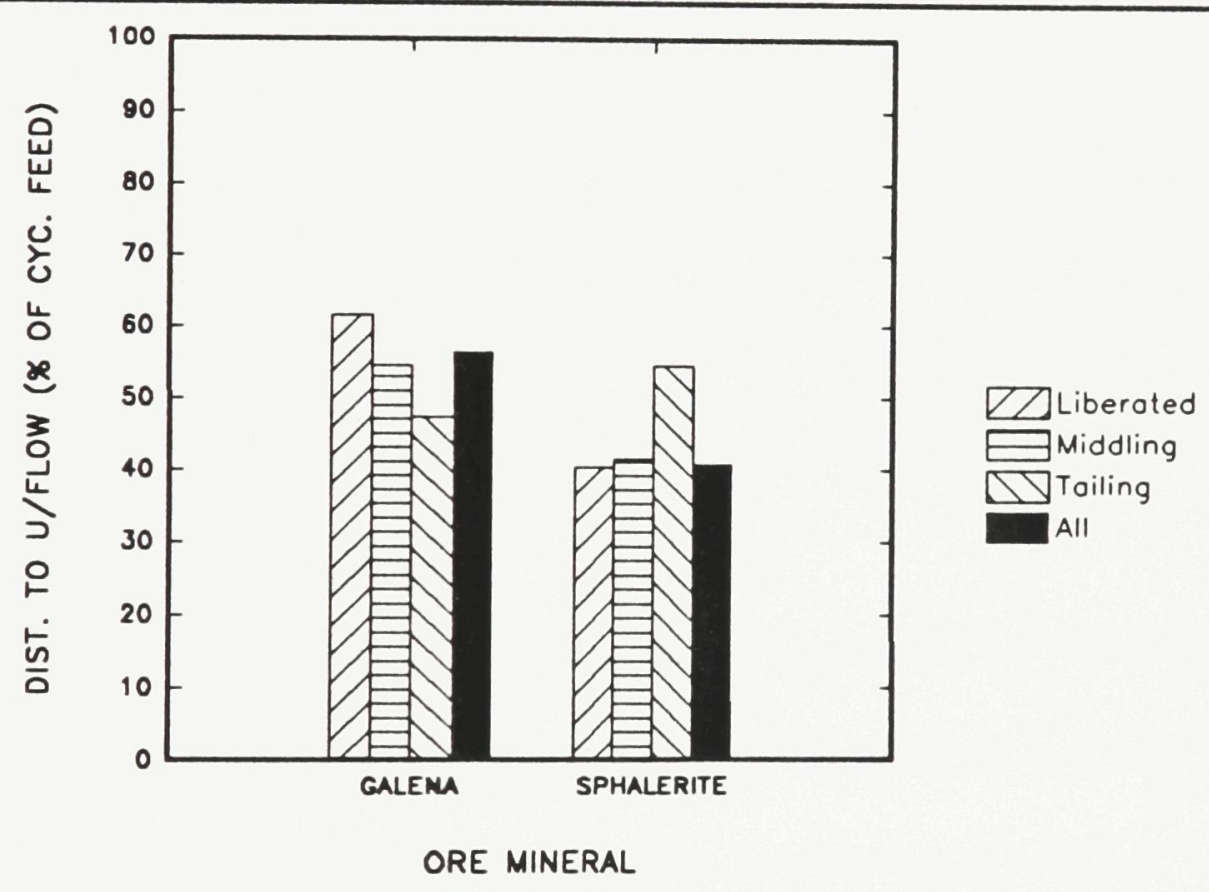

Figure 47 Galena and sphalerite distribution by liberation class to Vangorda lead scavenger regrind cyclone underflow. 
45).

Sphalerite distribution to the cyclone underflow is $41 \%$ of the sphalerite in the cyclone feed (Figure 47). Sphalerite distributions for the "liberated", middling and tailings classes are $40 \%, 42 \%$ and $55 \%$, respectively. Sphalerite "liberation" is $87 \%$ in the regrind circuit feed (SCF) and $85 \%$ in the product (SCOF) indicating a negligible increase in liberation (Figure 45).

Pyrite "liberation" does not increase either (Figure 45).

Lead cleaners

Recovery of galena to the first cleaner concentrate is $85 \%$ of the galena in the first cleaner feed whereas recovery of "liberated" galena is $89 \%$ (Figure 48). Distribution of sphalerite to the first cleaner concentrate is $61 \%$ of sphalerite in the first cleaner feed whereas that of "liberated" sphalerite is also $61 \%$ (Figure 49). This shows poor rejection of sphalerite by the first cleaners. The first cleaner tail consists of 4.25 TPH galena of which $58 \%$ is "liberated" and $7.23 \mathrm{TPH}$ sphalerite of which $87 \%$ is "liberated" (Figure 44).

Sphalerite distribution to the second cleaner concentrate is $66 \%$ of the sphalerite in the second cleaner feed (Figure 49). This suggests that sphalerite is not being depressed sufficiently. Galena recovery is $80 \%$ of galena in the second cleaner feed whereas "liberated" galena recovery is $83 \%$ (Figure 48 ). Recovery of galena in the unliberated classes $(0-70 \%)$ is $71 \%$. 


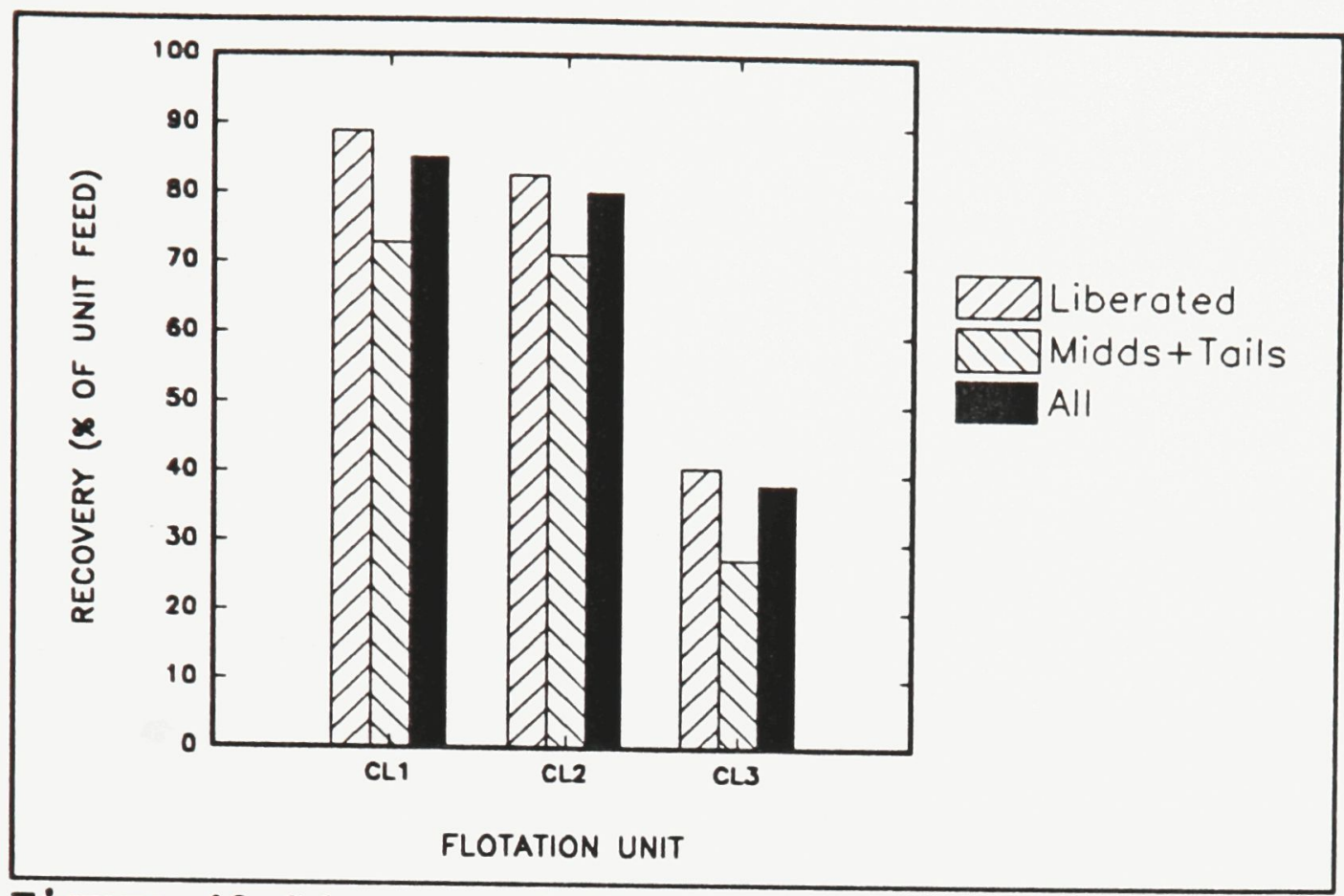

Figure 48 Galena recovery by liberation class in Vangorda lead cleaner circuit.

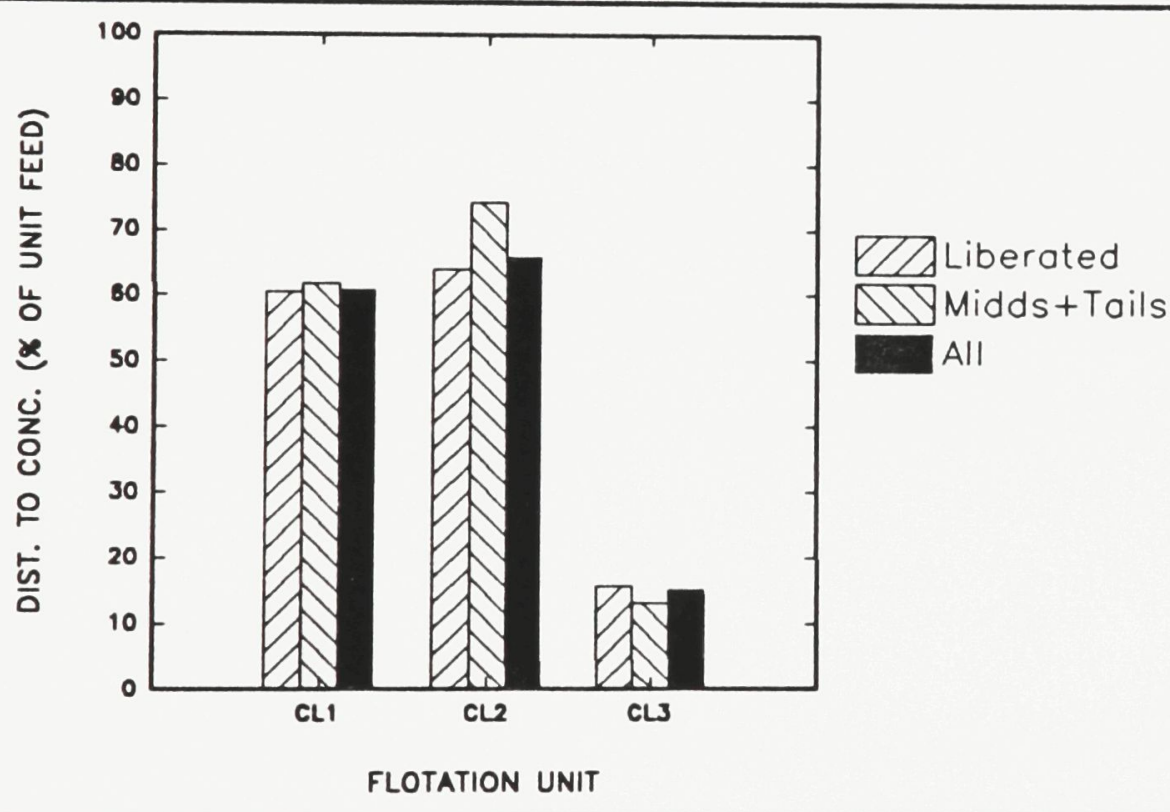

Figure 49 Sphalerite distribution by liberation class in Vangorda lead cleaner circuit. 
In the third cleaners galena recovery is $38 \%$ of the galena in the third cleaner feed whereas "liberated" galena recovery is $41 \%$, indicating poor cleaning action (Figure 48 ). Sphalerite distribution to the final lead concentrate is $15 \%$ of the sphalerite in the third cleaner feed (Figure 49).

Liberation and Distributions of Sphalerite and Galena in the Zinc Flotation Circuit Rougher-scavenger flotation $\mathrm{K}+\mathrm{L}$ banks

The rougher cells recover $78 \%$ of the sphalerite (Figure 50 ) and distribute to the concentrate $51 \%$ of the galena (Figure 51). The sphalerite reporting to the rougher tails amounts to $10 \mathrm{TPH}$ of which about $67 \%$ is 'liberated" (Figure 52).

The scavenger cells recover $62 \%$ of the sphalerite in the rougher tails which results in a combined rougher-scavenger sphalerite recovery of $90 \%$ (Figure 50). The remaining $10 \%$ of the sphalerite which is lost to the scavenger tails is predominantly (64\%) "liberated" (Figure 52). The distribution of galena by the combined rougher-scavengers to the concentrates is $62 \%$ (Figure 51 ). It is concluded that the rougher-scavengers recover most of the recoverable sphalerite but some "liberated" sphalerite is lost.

Hydrocyclone - regrind ball mill

The hydrocyclone distributes to the underflow $74 \%$ of the sphalerite in the cyclone feed (Figure 54). The sphalerite distributions to the underflow for the "liberated", middling and tailing classes are $72 \%, 89 \%$ and $87 \%$, respectively. Sphalerite "liberation" is $83 \%$ in the feed to the regrind circuit (R KL) (Figure 52) and $95 \%$ in the regrind cyclone 
175

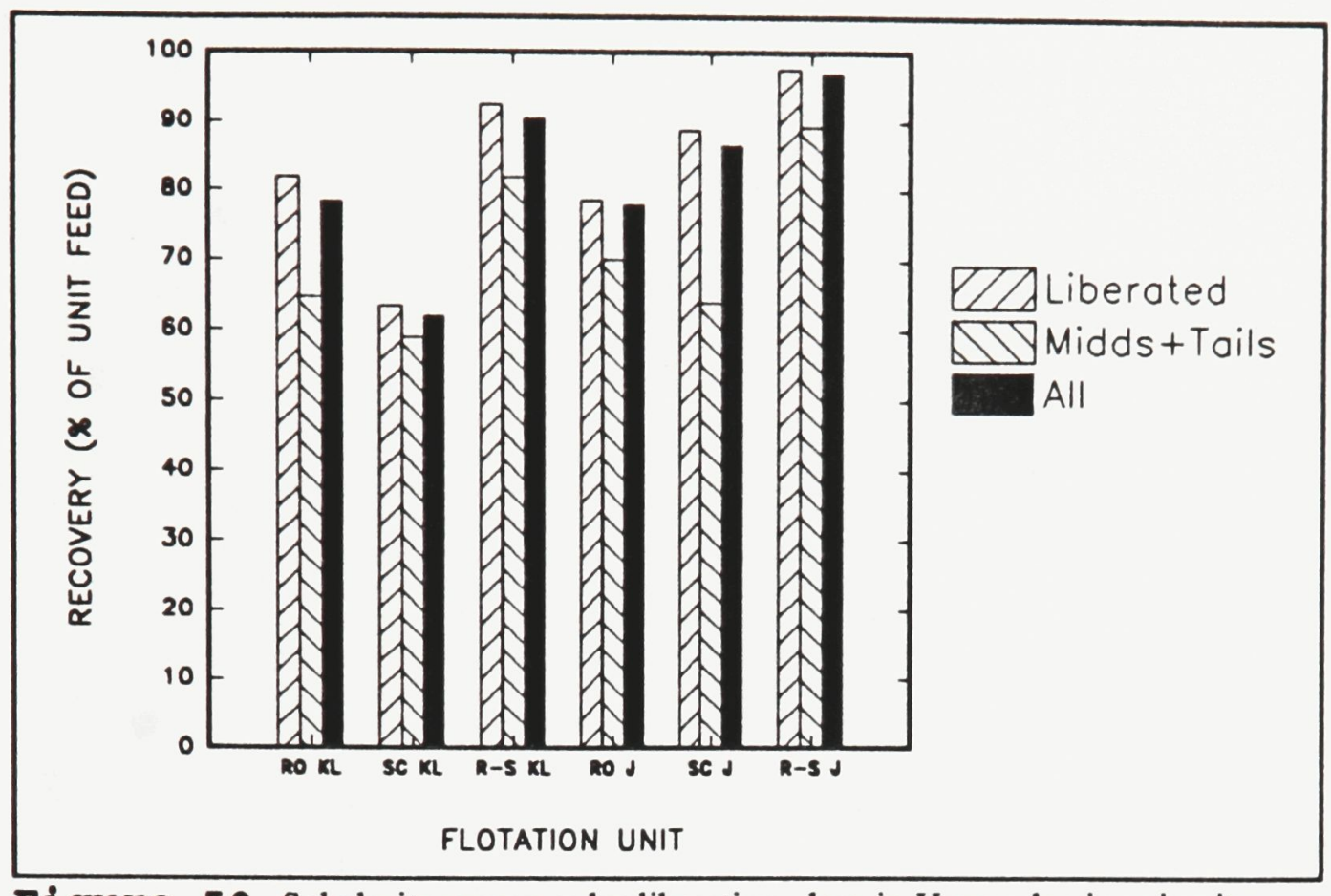

Figure 50 Sphalerite recovery by liberation class in Vangorda zinc circuit.

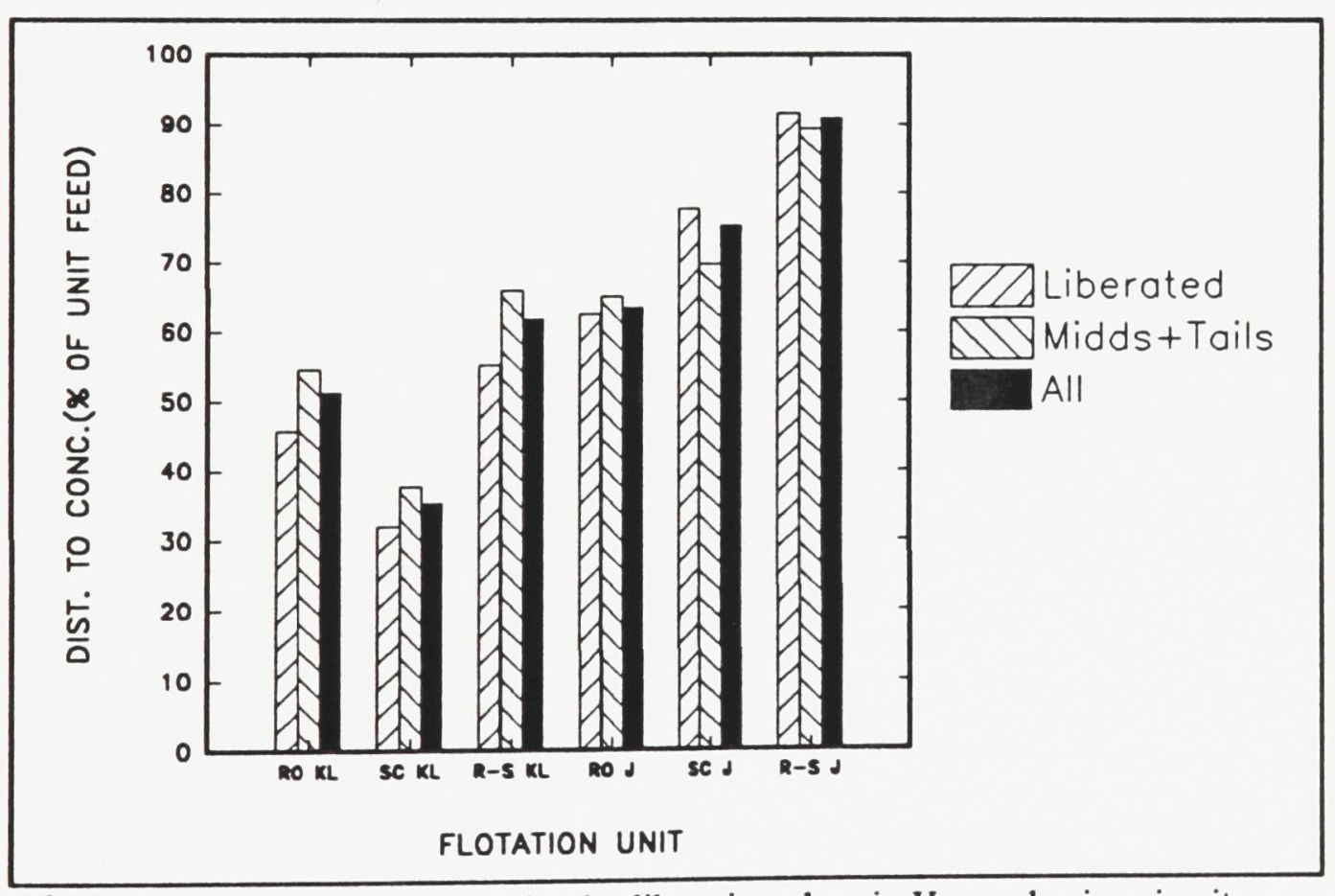

Figure 51 Galena distribution by liberation class in Vangorda zinc circuit. 


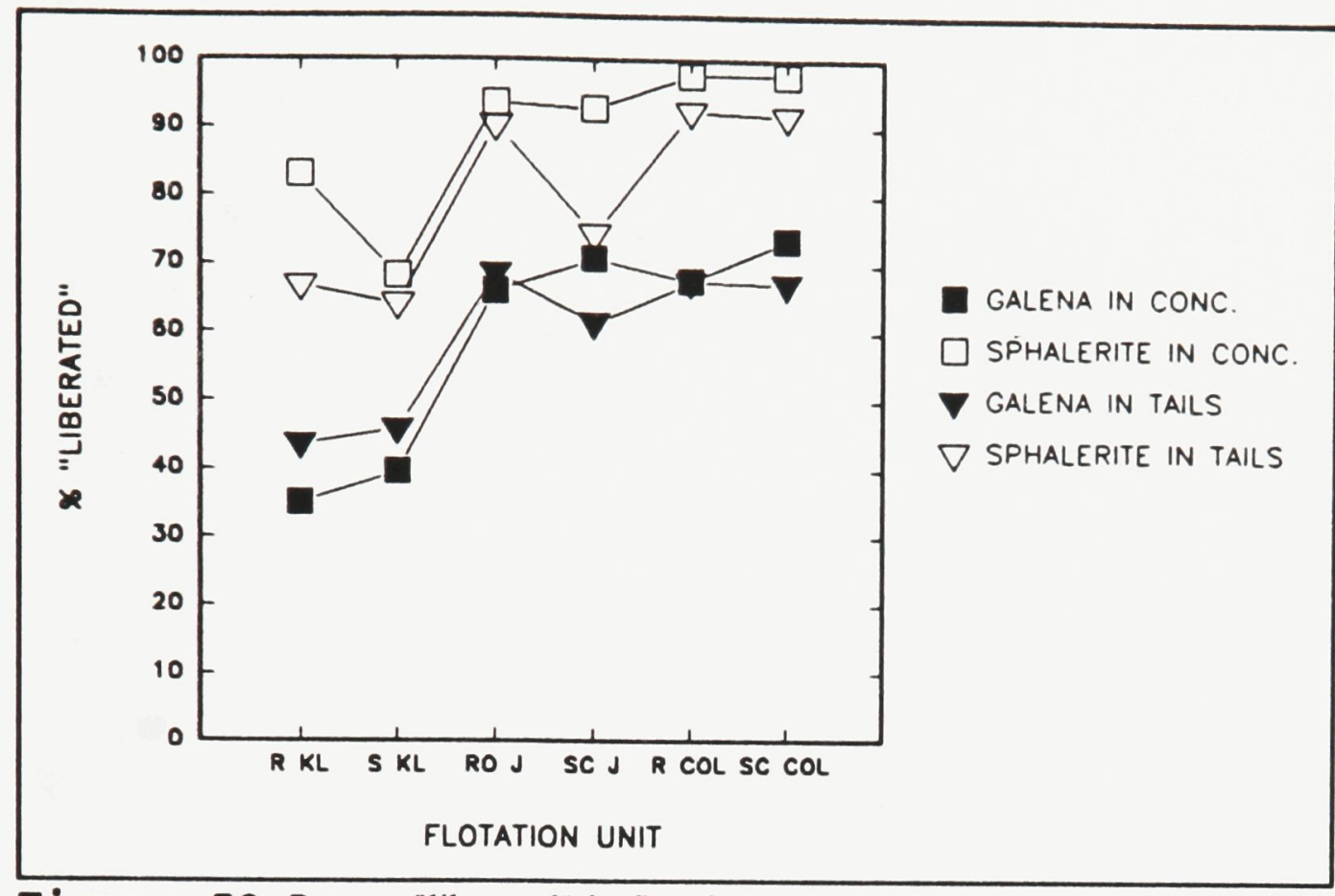

Figure 52 Percent "liberated" in flotation streams of Vangorda zinc circuit.

overflow (COF), indicating a significant increase in "liberation" (Figure 53). Galena "liberation" increases from $35 \%$ to $66 \%$ across the ball mill (Figures 52 and 53 ).

A comparison of galena "liberation" in the the Faro regrind circuits with the Vangorda regrind circuits shows that "liberation" of galena does not increase in any of the three lead regrind circuits but does increase by a large amount in both zinc regrind circuits. This is a curious result and can not be explained by differences in the mineralogical characteristics of the lead and zinc regrind streams.

\section{Rougher-scavenger flotation J bank}

The rougher-scavenger $\mathrm{J}$ bank of flotation cells upgrade the reground rougher concentrate and the column tailings. Recovery of sphalerite in the rougher concentrate is $78 \%$ of the sphalerite in the feed to the J bank and the recovery of "liberated" sphalerite 


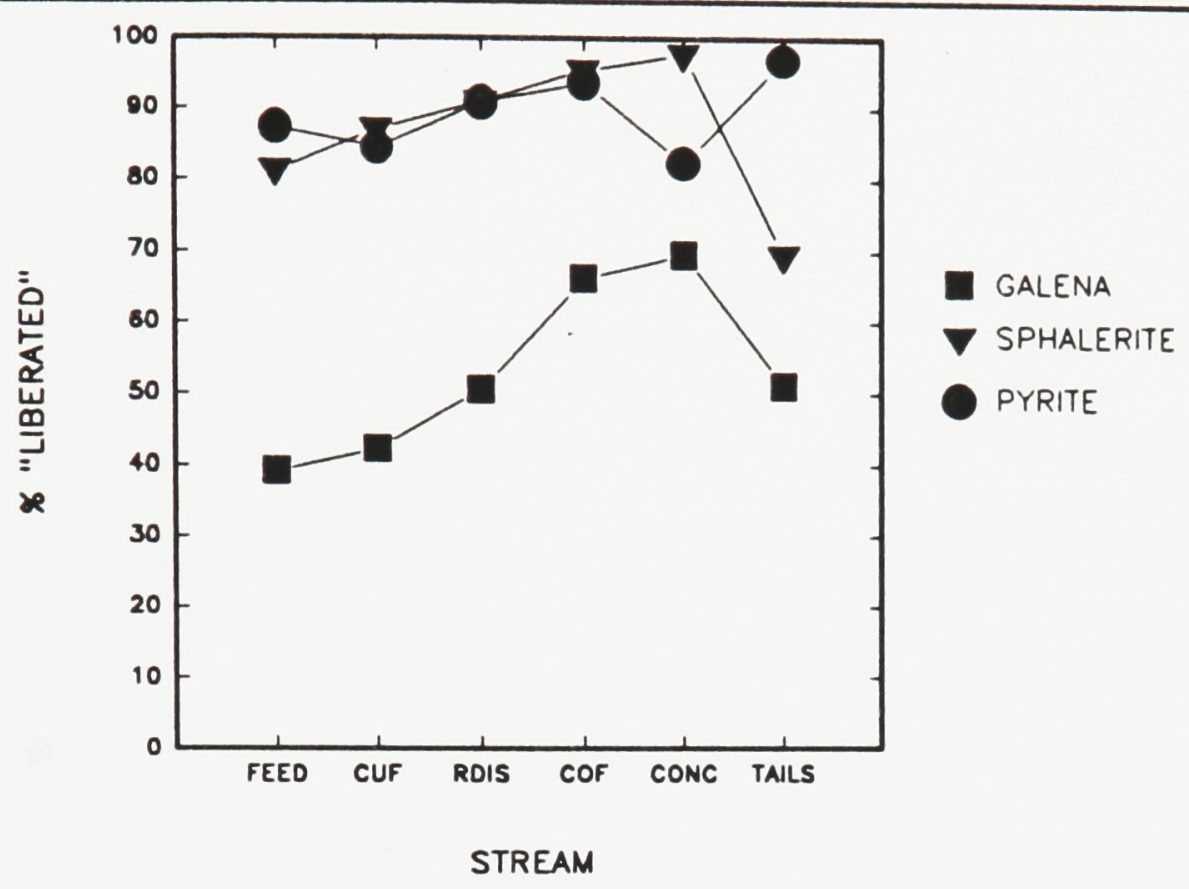

Figure 53 Percent "liberated" in selected streams of Vangorda zinc circuit.

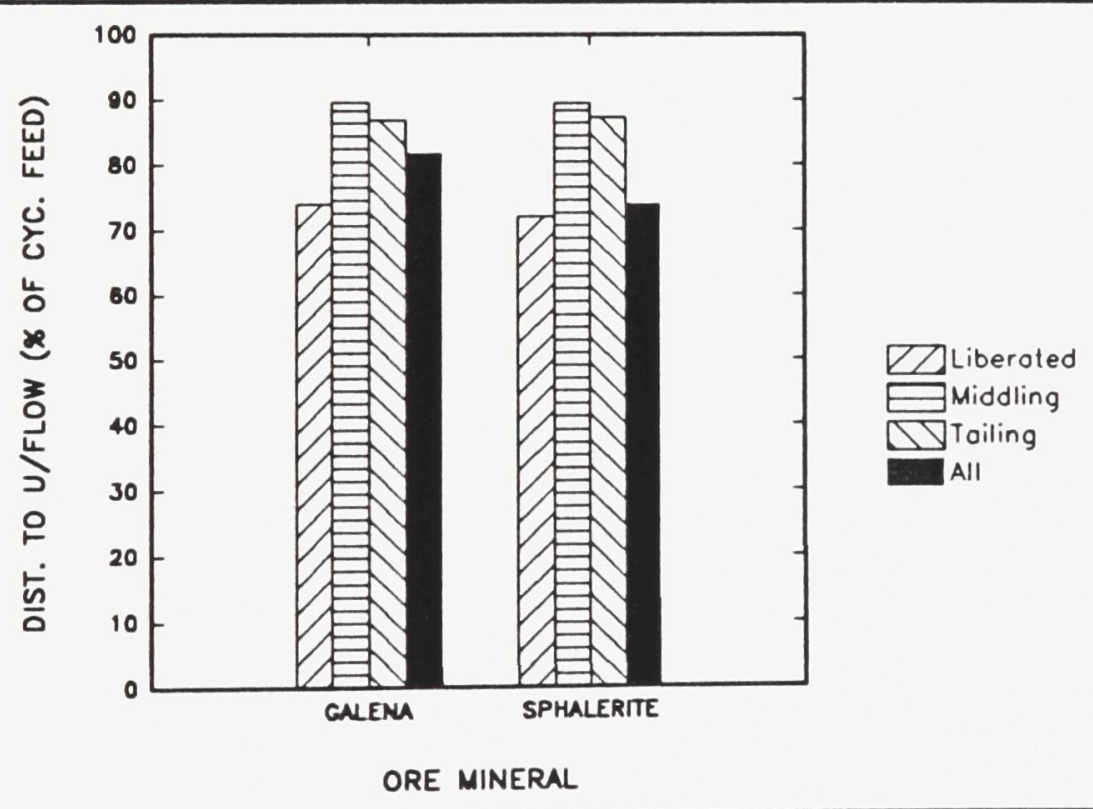

Figure 54 Galena and sphalerite distribution by liberation class to Vangorda zinc regrind cyclone underflow. 
is $79 \%$ (Figure 50 ). Distribution of galena to the rougher concentrate is $63 \%$ of the galena in the J bank feed whereas that of "liberated" galena is also $63 \%$ (Figure 51). These data show poor rejection of galena by the roughers. The rougher tail consists of $31 \mathrm{TPH}$ sphalerite of which $90 \%$ is "liberated" (Figure 52).

In the $\mathrm{J}$ bank scavengers sphalerite recovery is $86 \%$ of the sphalerite in the scavenger feed whereas "liberated" sphalerite recovery is $89 \%$ (Figure 50). Galena distribution to the concentrate is $75 \%$ of the galena in the scavenger feed, up from $63 \%$ in the roughers (Figure 51). The galena in the scavenger conc is $71 \%$ "liberated" (Figure 52). Overall the rougher-scavengers recover $97 \%$ of the total sphalerite and $98 \%$ of the "liberated" sphalerite (Figure 50). However, they also distribute $91 \%$ of the galena and $92 \%$ of the "liberated" galena to the concentrate (Figure 51). Obviously, there is little rejection of "liberated" galena.

Rougher-scavenger columns circuit

The purpose of the column circuit is to upgrade the concentrate to obtain final grade zinc concentrate. Sphalerite recovery in the roughers is $18 \%$ (Figure 55) whereas galena distribution to the concentrate is $10 \%$ of galena in the rougher feed (Figure 56). The sphalerite in the rougher column concentrate is $98 \%$ "liberated" whereas the sphalerite in the tails is $92 \%$ "liberated" (Figure 52). Most of the galena in the concentrate is "liberated" (68\%).

In the scavenger column sphalerite recovery is $11 \%$ (Figure 55) whereas galena distribution to the concentrate is $4 \%$ (Figure 56). The sphalerite in the scavenger column 


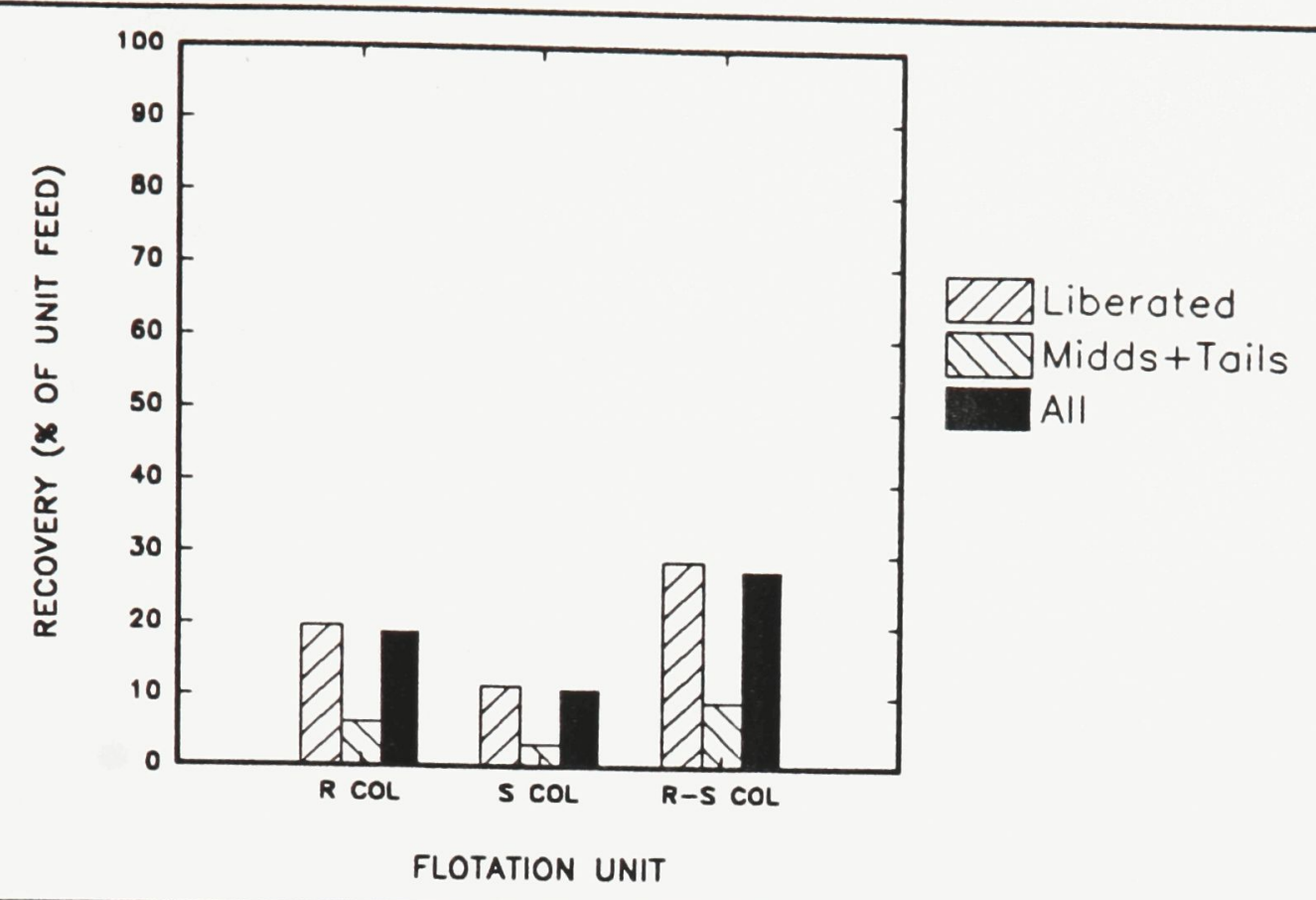

Figure 55 Sphalerite recovery by liberation class in Vangorda zinc column circuit.

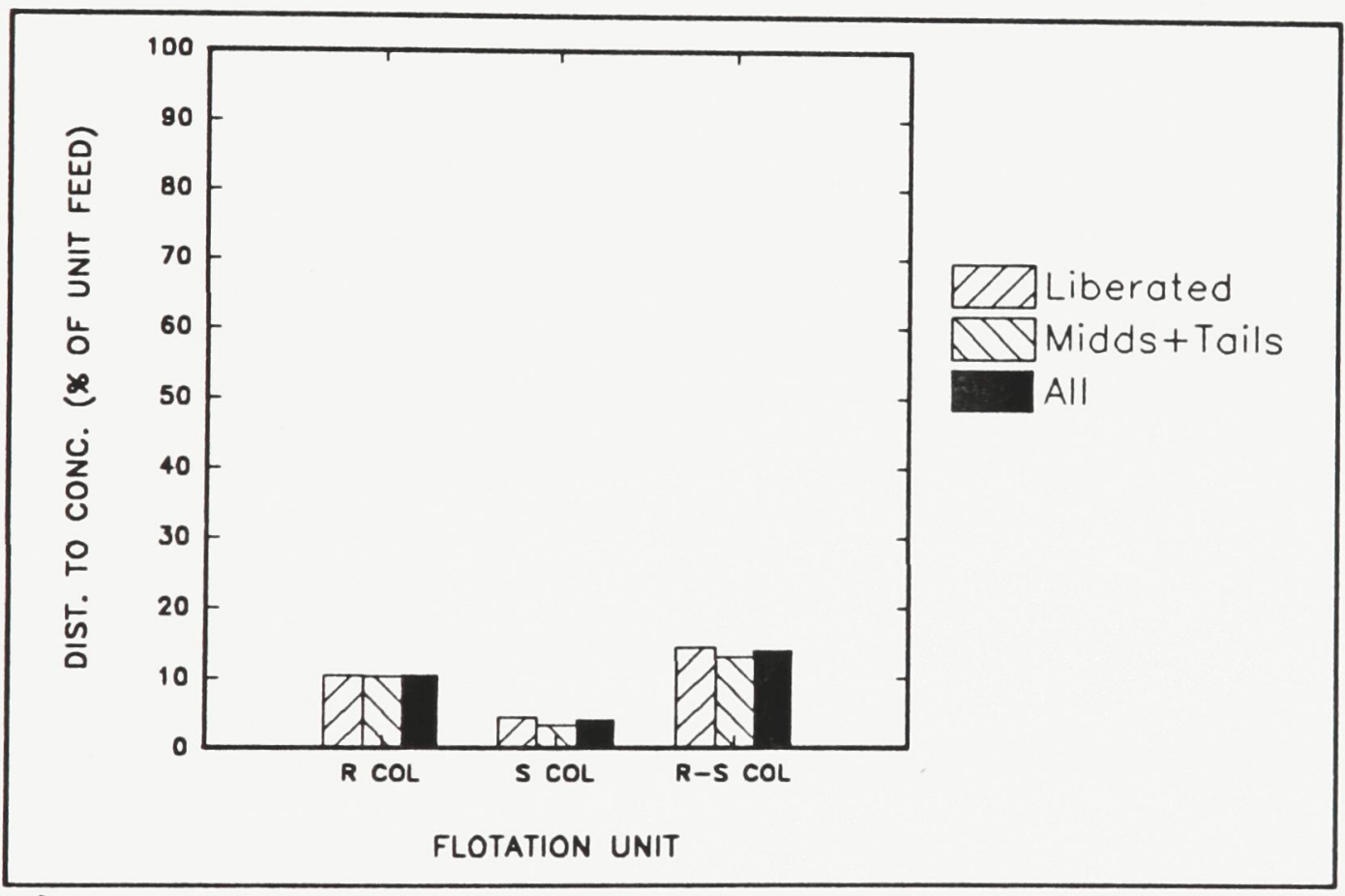

Figure 56 Galena distribution by liberation class in Vangorda zinc column circuit. 
concentrate is $98 \%$ "liberated" whereas the sphalerite in the tails is $92 \%$ "liberated". Most of the galena in the scavenger column concentrate is "liberated" (74\%) (Figure 52).

Taken together the two columns recover $27 \%$ of the total sphalerite and $29 \%$ of the "liberated" sphalerite (Figure 55). The combined column concentrate, i.e. the final zinc concentrate, contains 2.17 TPH of galena which is $70 \%$ "liberated".

Final tailings

The final tailings contain $8.12 \mathrm{TPH}$ of sphalerite which is $70 \%$ "liberated" and 4.63 TPH of galena of which $51 \%$ is "liberated" (Figure 53).

In summary, the data for sphalerite show that:

1. Most of the sphalerite recovered in the final zinc concentrate was "liberated" sphalerite (98\%),

2. $84 \%$ of the sphalerite lost to the final lead concentrate was "liberated" and $70 \%$ of the sphalerite lost to the final tailings was "liberated". This indicates that sphalerite liberation is not a major factor in zinc losses.

In summary, the data for galena show that:

1. Most of the galena recovered in the final lead concentrate was "liberated" galena (87\%),

2. Only small amounts of galena recovered in the final lead concentrate were in middling (12\%) and tailing (1\%) class particles, 
3. $56 \%$ of the galena lost to the lead scavenger tails was not "liberated". This indicates that the liberation of galena is not at optimum.

Mineral Associations of Sphalerite and Galena

Unbroken concentrator feed

The mineral associations of sphalerite and galena in the unbroken concentrator feed were measured and combined with those of the $4 E$ and $4 G$ core samples and are given in Table 44.

\section{TABLE 44}

MINERAL ASSOCLATIONS IN ROD MILL FEED (\%PERIMETER)

\begin{tabular}{|c|c|c|c|c|c|c|}
\hline \multicolumn{7}{|c|}{ GALENA } \\
\hline QTZ & $\begin{array}{c}\text { SID + } \\
\text { ANK }\end{array}$ & PY & CP & BAR & PO & $\begin{array}{c}\text { SP / } \\
\text { GAL }\end{array}$ \\
\hline 3 & 9 & 19 & 0 & 50 & 0 & 19 \\
\hline \multicolumn{7}{|c|}{ SPHALERTE } \\
\hline 2 & 9 & 18 & 1 & 48 & 0 & 22 \\
\hline
\end{tabular}

Preferred Breakage

A comparison of the mineral associations of galena and sphalerite in those samples (Table 44) with that of the normalized mineral associations in the lead circuit feed (Table 45) shows significant differences. The sequence of the mineral association data for galena show a significant increase in the proportion of galena-carbonate (siderite-ankerite) 


\section{TABLE 45}

NORMALIZED MINERAL ASSOCIATIONS OF GALENA AND SPHALERTE IN LEAD CIRCUIT FEED (PERIMETER \%)

\begin{tabular}{|c|c|c|c|c|c|c|c|}
\hline \multicolumn{10}{|c|}{ GALENA } \\
\hline & QTZ & $\begin{array}{c}\text { SID }+ \\
\text { ANK }\end{array}$ & PY & CP & BAR & PO & $\begin{array}{c}\text { SP / } \\
\text { GAL }\end{array}$ \\
\hline & 9 & 30 & 12 & 0 & 7 & 4 & 38 \\
\hline INDEX & 2.0 & 2.33 & -.37 & na & -.86 & na & 1.0 \\
\hline & & & \multicolumn{7}{|c|}{ SPHALERTE } & & 3 \\
\hline & 2 & 37 & 14 & 2 & 7 & 3 & 35 \\
\hline INDEX & 0 & 3.11 & -.22 & 1.0 & -.85 & na & .59 \\
\hline
\end{tabular}

$($ INDEX $=2.33)$ and galena-sphalerite $($ INDEX $=1.0)$ interface and a significant decrease in galena-barite (INDEX $=-.86$ ) interface. This indicates a strong bonding of galena to carbonates and sphalerite, weak bonding (preferential breakage) of galena to barite and moderate bonding of galena to pyrite and quartz. The sphalerite data show a significant increase in the proportion of sphalerite-carbonate (INDEX $=3.11$ ) and sphalerite-galena $($ INDEX $=.59)$ interface and a significant decrease in sphalerite-barite (INDEX $=-.85)$ interface. This indicates strong bonding of sphalerite to carbonates and galena, weak bonding of sphalerite to barite, and moderate bonding of sphalerite to pyrite, quartz and chalcopyrite.

The sequence of increasing bond strength of sphalerite with the major minerals is:

$$
\text { BARITE } \rightarrow \text { PYRITE } \rightarrow \text { GALENA } \rightarrow \text { CARBONATES }
$$

Similarly, the sequence for galena is:

$$
\text { BARITE } \rightarrow \text { PYRITE } \rightarrow \text { SPHALERITE } \rightarrow \text { CARBONATES }
$$


A similar breakage behaviour pattern is observed here as was seen in the Faro ore. Carbonate (mostly siderite) and sphalerite tend not to break away from galena but barite and pyrite do. In contrast to Faro, pyrite in Vangorda ore does not show a strong tendency to break away from sphalerite and galena. This difference may be due to the relative fineness of the Vangorda pyrite compared to that of the Faro.

Significantly, barite is easily detached from both galena and sphalerite which is fortunate in terms of mineral processing since most of the orebody consists of barite-rich 4G ore. Also the preferred attachment of galena and sphalerite with the carbonates and with each other is repeated again, as for the Faro ore.

\section{Concentrator samples}

The mineral associations in concentrator samples was determined as the weight distribution of each ore mineral in various types of locked binary and ternary particles. The balanced data for galena and sphalerite are shown in Tables 46 and 47, respectively. These results are discussed later.

The perimeter technique of measuring associations was also performed on the concentrator feed and final products (Appendix 21). The data for the lead conc., zinc conc. and the final tailings are shown in Table 48. The data in the table show that in the lead concentrate sphalerite is most strongly associated with galena and vice versa. This shows that the breakage of mineral pairs in the grinding circuit has resulted in galenasphalerite particles reporting to the lead concentrate. In the zinc concentrate sphaleritesiderite and sphalerite-galena particles represent most of the locking interface. This 
TABLE 46

BALANCED DISTRIBUTION OF SPHALERITE NHOWG BIMARY MND TERMARY PARTICLES

IN EACH STRENM OF VANGORDA LEAD CIRCUIT (WTX)

Stream

Rougher feed

Ro. conc. $g+h$

Rougher conc. i 56

Ro. tail $g+h$

Scav. conc. i

Rougher tail i

Scav. conc. $9+\mathrm{h}$

Scav. tail g+h 70

Scav. tail i

Tails

Cyc. underflow 70

Regrind disch.

Cycl. overflow $\quad 50$

Scav. cyc. u/f 72

Scav. reg. dis. 68

Scav. cyc. o/f 51

First $\mathrm{cl}$. conc. $\quad 58$

Sec. cl. conc. $\quad 58$

Third cl. conc. 55

First cl. tail 49

Second $\mathrm{cl}$. tail 56

Third cl. tail

44

67

50
Ternary
Porticles

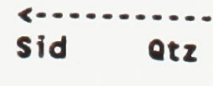

Binat

Part
Py

Partic

MIL NIL
6

$c_{p}$

Bar

Gal

Free Total

69

$23 \quad 13$

67

28

MIL NIL
6

1

NIL 19

$27 \quad 100$

$\begin{array}{rr}1 & 2 \\ 18 & 20\end{array}$

69

$\begin{array}{rr}1 & 1 \\ 22 & 13\end{array}$

NIL

NIL

NIL

$\begin{array}{ll}\text { NIL } & 3 \\ 3 & 47\end{array}$

27

100

51

NIL NIL
6

NIL

$\begin{array}{lr}1 & 3 \\ 2 & 30\end{array}$

$37 \quad 100$

$\begin{array}{rr}1 & 4 \\ 11 & 20\end{array}$

$\begin{array}{rr}4 & \text { NIL }\end{array}$

$\begin{array}{rrr}1 & \text { NIL } & \text { NIL } \\ 7 & 6 & 15\end{array}$

$28 \quad 100$

Co

$\begin{array}{rr}1 & 4 \\ 13 & 20\end{array}$

4
4

2

$\begin{array}{lrrr}\text { NIL } & 2 & 40 & 100\end{array}$

13

$\begin{array}{rr}1 & 2 \\ 28 & 24\end{array}$

NIL

NIL

${ }_{10}^{2}$

NIL 2

41

100

$\begin{array}{rr}1 & \text { NIL } \\ 22 & 12\end{array}$

NIL NIL

19

NIL $\quad 3 \quad 23$

$23 \quad 100$

$\begin{array}{rr}3 & 5 \\ 17 & 20\end{array}$

$\begin{array}{rrr}\text { NIL } & \text { NIL } & 4 \\ 5 & 6 & 18\end{array}$

$\begin{array}{rrrr}\text { NIL } & \text { NIL } & 28 & 100\end{array}$

$\begin{array}{cc}1 & 1 \\ 21 & 13\end{array}$

$\begin{array}{ccc}\text { NIL } & \text { NIL } & 1 \\ 6 & 10 & 8\end{array}$

$\begin{array}{llll}\text { NIL } & 1 & 43 & 100\end{array}$

$\begin{array}{llll}\text { NIL } & \text { NIL } & 30 & 100\end{array}$

$\begin{array}{rr}1 & \text { NIL } \\ 17 & 10\end{array}$

$\begin{array}{rrr}\text { NIL NIL } & 2 \\ 3 & 9 & 17\end{array}$

$\begin{array}{lrll}\text { NIL } & 4 & 23 & 100\end{array}$

6

$\begin{array}{rrr}1 & 1 & \text { NIL } \\ 14 & 8\end{array}$

$\begin{array}{rrr}\text { NIL } & \text { NIL } & 2 \\ 2 & 9 & 18\end{array}$

NIL $\quad \begin{array}{r}5 \\ 6\end{array} \quad 25 \quad 100$

$\begin{array}{rr}1 & 2 \\ 12 & 12\end{array}$

NIL NIL

NIL 8

83

$38 \quad 100$

72

NIL NIL
13

$\begin{array}{rrr}\text { NIL } & \text { NIL } & \text { NIL } \\ 3 & 8 & 16\end{array}$

$\begin{array}{rr}\text { NIL } & 7 \\ 5 & 48\end{array}$

$21 \quad 100$

$\begin{array}{rr}1 & 1 \\ 12 & 16\end{array}$

NI

NIL $\quad \begin{array}{r}7 \\ 7\end{array}$

NIL $\quad 6$

$23 \quad 100$

$\begin{array}{rr}1 & 4 \\ 14 & 20\end{array}$

$\begin{array}{rr}4 & \text { NIL }\end{array}$

2

$\begin{array}{lr}\text { NIL } & 2 \\ \text { NIL } & 17\end{array}$

$40 \quad 100$

$\begin{array}{rr}\text { NIL } & 1 \\ 9 & 10\end{array}$

$\begin{array}{rrr}\text { NIL } & \text { MIL } & \text { NIL } \\ 2 & 2 & 14\end{array}$

NIL $\quad 9$

$32 \quad 100$

$\begin{array}{rr}\text { NIL } & 1 \\ 11 & 12\end{array}$

NIL

NIL 19

NIL $\quad 9 \quad 31$

100

NIL NIL

NIL

NIL

NIL

$\begin{array}{llll}\text { NIL } & 16 & 29 & 100\end{array}$

$\begin{array}{rr}1 & 3 \\ 14 & 15\end{array}$

MII

$\begin{array}{rr}1 & 1 \\ 10 & 12\end{array}$

MII

NIL

NIL
7

1

$\begin{array}{rr}\text { NIL } & 5 \\ 3 & 21\end{array}$

$41 \quad 100$

$\begin{array}{rr}\text { NIL } & 1 \\ 3 & 17\end{array}$

NIL

31

33

100

$\begin{array}{rr}1 & 2 \\ 13 & 14\end{array}$

NIL

12

$\begin{array}{rrrr}\text { NIL } & 8 & 31 & 100 \\ 3 & 36 & & \end{array}$ 
TABLE 46 (CONTINUED)

BALANCED DISTRIBUTION OF SPHALERITE AMONG BIMARY ANO TERMARY PARTICLES IN EACH STRENH OF VANGORDA ZINC CIRCUIT (WTX)

\begin{tabular}{|c|c|c|c|c|c|c|c|c|c|c|}
\hline Stream & $\begin{array}{l}\text { Ternery } \\
\text { Particles }\end{array}$ & sid & otz & $\begin{array}{l}\text { Bin } \\
\text { Ank }\end{array}$ & $\begin{array}{l}\text { iry Par } \\
\text { Py }\end{array}$ & $\begin{array}{l}\text { cles. } \\
\text { Cp }\end{array}$ & Bar & Gal & Free & Total \\
\hline Feed & 73 & 24 & ? & $\begin{array}{r}\text { MIL } \\
8\end{array}$ & ${ }_{13}^{\text {MIL }}$ & $\begin{array}{c}1 \\
16\end{array}$ & MIL & $\begin{array}{r}1 \\
14\end{array}$ & 23 & 100 \\
\hline Ro. feed $l+k$ & 69 & $\begin{array}{r}1 \\
28\end{array}$ & 11 & $\begin{array}{l}\text { MIL } \\
10\end{array}$ & $\underset{14}{\text { NIL }}$ & $\begin{array}{r}1 \\
16\end{array}$ & MIL & $\begin{array}{r}1 \\
15\end{array}$ & 27 & 100 \\
\hline Ro. conc. $1+k$ & 64 & 24 & $\begin{array}{l}1 \\
7\end{array}$ & $\begin{array}{r}\text { MIL } \\
8\end{array}$ & $\begin{array}{l}\text { MIL } \\
13\end{array}$ & $\begin{array}{r}1 \\
17\end{array}$ & MIL & 14 & 32 & 100 \\
\hline Ro. tail l+k & 71 & 41 & $\begin{array}{r}1 \\
27\end{array}$ & ${ }_{16}^{\text {MIL }}$ & $\underset{18}{\text { NIL }}$ & $\begin{array}{r}1 \\
10\end{array}$ & $\begin{array}{r}\text { MIL } \\
8\end{array}$ & ${ }_{16}^{\text {NIL }}$ & 26 & 100 \\
\hline Scav. conc. $1+k$ & 72 & $\begin{array}{r}1 \\
50\end{array}$ & $24^{2}$ & ${ }_{19}^{\text {NIL }}$ & $\begin{array}{l}\text { NIL } \\
19\end{array}$ & $\begin{array}{r}1 \\
13\end{array}$ & WIL & $\begin{array}{r}\text { NIL } \\
21\end{array}$ & 24 & 100 \\
\hline Scav. tail l+k & 67 & $\begin{array}{r}1 \\
25\end{array}$ & $\begin{array}{r}\text { MIL } \\
32\end{array}$ & MIL & $\underset{15}{\text { MIL }}$ & $\begin{array}{l}1 \\
5\end{array}$ & NIL & NIL & 31 & 100 \\
\hline Regr. cyc. u/f & 71 & $\begin{array}{r}1 \\
28\end{array}$ & $\begin{array}{l}\text { NIL } \\
3\end{array}$ & MIL & 21 & $\begin{array}{r}1 \\
24\end{array}$ & ${ }_{10}^{\text {MIL }}$ & $\begin{array}{l}2 \\
3\end{array}$ & 23 & 100 \\
\hline Regr. discharge & 67 & $\begin{array}{r}1 \\
22\end{array}$ & $\begin{array}{l}\text { NIL } \\
\text { NIL }\end{array}$ & WIL & $\underset{17}{\text { NIL }}$ & $\underset{18}{\text { NIL }}$ & MIt & $\begin{array}{l}2 \\
5\end{array}$ & 30 & 100 \\
\hline Regr. cyc. o/f & 46 & $\begin{array}{r}1 \\
47\end{array}$ & $\begin{array}{l}\text { NIL } \\
\text { WIL }\end{array}$ & $\begin{array}{r}\text { NIL } \\
2\end{array}$ & ${ }_{3}^{\text {WIL }}$ & $\begin{array}{r}\text { MIL } \\
2\end{array}$ & MIL & 20 & 52 & 100 \\
\hline Ro. conc. j & 59 & ${ }_{12}^{\text {NIL }}$ & $\begin{array}{r}\text { NIL } \\
2\end{array}$ & NIL & $\underset{5}{\text { MIL }}$ & NIL & ${ }_{3}^{\text {MIL }}$ & $\begin{array}{r}1 \\
16\end{array}$ & 40 & 100 \\
\hline Rougher tail j & 47 & $\begin{array}{l}1 \\
9\end{array}$ & $\begin{array}{r}\text { NIL } \\
2\end{array}$ & MIL & MIL & 11 & WIL & $\begin{array}{r}1 \\
12\end{array}$ & 50 & 100 \\
\hline Scav. conc. $j$ & 50 & $\begin{array}{l}1 \\
9\end{array}$ & $\frac{\text { NIL }}{2}$ & $\underset{4}{\text { NIL }}$ & $\begin{array}{r}\text { NIL } \\
5\end{array}$ & $\begin{array}{r}1 \\
13\end{array}$ & MIL & $\begin{array}{c}1 \\
13\end{array}$ & 47 & 100 \\
\hline Scav. tail j & 36 & $\begin{array}{l}1 \\
9\end{array}$ & $\underset{1}{\text { NIL }}$ & $\begin{array}{r}\text { MIL } \\
2\end{array}$ & $\begin{array}{r}\text { MIL } \\
12\end{array}$ & $\begin{array}{l}1 \\
3\end{array}$ & $\begin{array}{l}1 \\
6\end{array}$ & NIL & 61 & 100 \\
\hline Ro. col. conc. & 45 & $\begin{array}{r}\text { NIL } \\
4\end{array}$ & $\begin{array}{l}\text { NIL } \\
\text { MIL }\end{array}$ & NIL & NIL & $\begin{array}{l}\text { NIL } \\
\text { NIL }\end{array}$ & ${ }_{1}^{\text {MIL }}$ & $\begin{array}{r}1 \\
20\end{array}$ & 54 & 100 \\
\hline Ro. colum tail & 59 & $\underset{13}{\text { MIL }}$ & $\begin{array}{r}\text { NIL } \\
2\end{array}$ & $\begin{array}{r}\text { NIL } \\
8\end{array}$ & $\begin{array}{r}\text { NIL } \\
6\end{array}$ & NIL & ${ }_{3}^{\text {MIL }}$ & $\begin{array}{r}1 \\
14\end{array}$ & 39 & 100 \\
\hline Sc. col. conc. & 55 & $\underset{11}{\text { NIL }}$ & NIL & $\underset{3}{\text { NIL }}$ & ${ }_{4}^{\text {MIL }}$ & NIL & ${ }_{1}^{\text {NIL }}$ & 21 & 44 & 100 \\
\hline Scav. col. tail & 60 & ${ }_{13}^{\text {NIL }}$ & $\underset{3}{\text { NIL }}$ & NIL & NIL & NIL & ${ }_{3}^{\text {NIL }}$ & $\begin{array}{r}1 \\
14\end{array}$ & 39 & 100 \\
\hline Zinc conc. & 48 & $\begin{array}{r}\text { MIL } \\
6\end{array}$ & $\begin{array}{l}\text { NIL } \\
\text { NIL }\end{array}$ & $\begin{array}{r}\text { MIL } \\
2\end{array}$ & $\begin{array}{r}\text { NIL } \\
2\end{array}$ & $\begin{array}{r}\text { MIL } \\
2\end{array}$ & NIL & 21 & 51 & 100 \\
\hline Final tail & 53 & $\begin{array}{r}1 \\
17\end{array}$ & ${ }_{16}^{\text {NIL }}$ & $\begin{array}{r}\text { NIL } \\
6\end{array}$ & ${ }_{13}^{\text {MIL }}$ & $\begin{array}{l}1 \\
4\end{array}$ & $\begin{array}{l}1 \\
6\end{array}$ & ${ }_{10}^{\text {NIL }}$ & 44 & 100 \\
\hline
\end{tabular}

100\%. The distribution of the ternaries, given in the second line for each stream, does not sum to $100 \%$. 
TABLE 47

BALANCED DISTRIBUTION OF GALEMA NMONG BINARY AND TERMARY PARTICLES IN EACH STREAM OF VAMGORDA LEAD CIRCUIT (UTX)

\begin{tabular}{|c|c|c|c|c|c|c|c|c|c|c|}
\hline Stream & $\begin{array}{c}\text { Ternary } \\
\text { Particles }\end{array}$ & sid & atz & $\begin{array}{l}\text { - Bin } \\
\text { Ank }\end{array}$ & $\begin{array}{l}\text { ry Par } \\
\text { Py }\end{array}$ & $\operatorname{les}^{\circ}$ & Bar & $\overrightarrow{s p}$ & Free & Tota \\
\hline Rougher feed & 61 & 24 & $24^{2}$ & NIL & $\begin{array}{l}\text { MIL } \\
12\end{array}$ & NIL & NIL & $\begin{array}{r}1 \\
15\end{array}$ & 35 & 100 \\
\hline Ro. conc. $\theta^{+h}$ & 53 & $\begin{array}{l}\text { NIL } \\
12\end{array}$ & 20 & $\begin{array}{r}\text { NIL } \\
2\end{array}$ & $\begin{array}{l}1 \\
2\end{array}$ & $\begin{array}{l}\text { MIL } \\
\text { MIL }\end{array}$ & NIL & $\begin{array}{r}1 \\
10\end{array}$ & 42 & 100 \\
\hline Rousher conc. i & 37 & $\begin{array}{r}3 \\
15\end{array}$ & $\begin{array}{r}6 \\
13\end{array}$ & $\begin{array}{l}1 \\
5\end{array}$ & MIL & MIL & $\begin{array}{r}\text { MIL } \\
2\end{array}$ & 12 & 50 & 100 \\
\hline Ro. tail g+h & 73 & $\begin{array}{r}1 \\
41\end{array}$ & 29 & $\begin{array}{l}\text { NIL } \\
14\end{array}$ & $\begin{array}{r}\text { NIL } \\
27\end{array}$ & $\begin{array}{r}\text { NIL } \\
6\end{array}$ & $\begin{array}{r}\text { NIL } \\
8\end{array}$ & 24 & 23 & 100 \\
\hline Scav. conc. i & 49 & $\begin{array}{r}3 \\
21\end{array}$ & $\begin{array}{r}5 \\
19\end{array}$ & $\begin{array}{r}\text { NIL } \\
9\end{array}$ & NIL & $\begin{array}{r}\text { NIL } \\
6\end{array}$ & $\begin{array}{l}\text { MIL } \\
\text { MIL }\end{array}$ & $\begin{array}{r}2 \\
15\end{array}$ & 41 & 100 \\
\hline Rougher tail i & 49 & $\begin{array}{r}3 \\
22\end{array}$ & $\begin{array}{r}5 \\
21\end{array}$ & $\begin{array}{r}\text { MIL } \\
10\end{array}$ & $\begin{array}{l}1 \\
9\end{array}$ & NIL & $\begin{array}{r}\text { NIL } \\
1\end{array}$ & $\begin{array}{r}2 \\
15\end{array}$ & 40 & 100 \\
\hline Scav. conc. $g^{+h}$ & 57 & $\begin{array}{r}1 \\
23\end{array}$ & $\begin{array}{r}2 \\
24\end{array}$ & $\begin{array}{l}\text { MIL } \\
10\end{array}$ & $\begin{array}{r}\text { MIL } \\
10\end{array}$ & $\begin{array}{r}\text { NIL } \\
6\end{array}$ & $\begin{array}{l}\text { MIL } \\
76\end{array}$ & $\begin{array}{r}1 \\
22\end{array}$ & 39 & 100 \\
\hline Scav. tail g+h & 82 & $\begin{array}{r}1 \\
51\end{array}$ & $\begin{array}{r}\text { MIL } \\
32\end{array}$ & $\begin{array}{r}\text { MIL } \\
16\end{array}$ & $\begin{array}{l}\text { NIL } \\
36\end{array}$ & NIL & MIL & $\frac{2}{25}$ & 15 & 100 \\
\hline Scav. tail i & 56 & ${ }^{2}$ & $\begin{array}{r}5 \\
33\end{array}$ & NIL & $\begin{array}{r}3 \\
17\end{array}$ & $\begin{array}{r}\text { NIL } \\
8\end{array}$ & $\begin{array}{l}1 \\
6\end{array}$ & $\begin{array}{r}1 \\
10\end{array}$ & 32 & 100 \\
\hline Tails & $\pi$ & $\begin{array}{r}1 \\
48\end{array}$ & $\begin{array}{r}1 \\
32\end{array}$ & $\begin{array}{l}\text { MIL } \\
16\end{array}$ & $\begin{array}{r}1 \\
33\end{array}$ & $\begin{array}{r}\text { NIL } \\
6\end{array}$ & NIL & $\begin{array}{r}23 \\
23\end{array}$ & 18 & 100 \\
\hline Cyc. underflow & 44 & $\begin{array}{r}1 \\
13\end{array}$ & 12 & NIL & $\begin{array}{l}1 \\
7\end{array}$ & NIL & NIL & $\begin{array}{r}1 \\
15\end{array}$ & 51 & 100 \\
\hline Regr. discharge & 41 & $\begin{array}{r}1 \\
12\end{array}$ & $\begin{array}{r}2 \\
10\end{array}$ & ${ }_{4}^{\text {NIL }}$ & $\begin{array}{r}\text { NIL } \\
\end{array}$ & $\begin{array}{r}\text { NIL } \\
3\end{array}$ & NIL & $\begin{array}{r}2 \\
15\end{array}$ & 55 & 100 \\
\hline Cyc. overflow & 34 & $\begin{array}{l}1 \\
8\end{array}$ & $\begin{array}{r}2 \\
10\end{array}$ & $\frac{\text { NIL }}{3}$ & $\begin{array}{r}\text { NIL } \\
5\end{array}$ & ${ }_{2}^{\text {NIL }}$ & NIL & $\begin{array}{r}2 \\
10\end{array}$ & 61 & 100 \\
\hline Scav. cyc. u/f & 50 & $\begin{array}{r}1 \\
13\end{array}$ & $\begin{array}{r}3 \\
14\end{array}$ & $\begin{array}{r}\text { NIL } \\
4\end{array}$ & $\begin{array}{r}\text { NIL } \\
8\end{array}$ & $\begin{array}{r}\text { NIL } \\
4\end{array}$ & ${ }_{3}^{\text {NIL }}$ & $\begin{array}{r}2 \\
13\end{array}$ & 44 & 100 \\
\hline Sc. reg. disch. & 46 & $\begin{array}{r}1 \\
11\end{array}$ & 11 & ${ }_{3}^{\text {NIL }}$ & NIL & NIL & NIL & $\begin{array}{r}2 \\
10\end{array}$ & 47 & 100 \\
\hline Sc. cyc. o/flow & 46 & $\begin{array}{r}3 \\
20\end{array}$ & $\begin{array}{r}5 \\
19\end{array}$ & $\begin{array}{r}\text { NIL } \\
8\end{array}$ & $\begin{array}{l}1 \\
9\end{array}$ & $\begin{array}{r}\text { NIL } \\
5\end{array}$ & $\begin{array}{r}\text { NIL } \\
1\end{array}$ & $\begin{array}{r}2 \\
14\end{array}$ & 43 & 100 \\
\hline First cl. conc. & 35 & $\begin{array}{l}1 \\
9\end{array}$ & $1_{11}^{2}$ & ${ }_{3}^{\text {NIL }}$ & ${ }_{4}^{\text {NIL }}$ & $\begin{array}{r}\text { NIL } \\
2\end{array}$ & NIL & $\begin{array}{r}3 \\
11\end{array}$ & 59 & 100 \\
\hline Sec. cl. conc. & 41 & $\begin{array}{r}1 \\
11\end{array}$ & $\begin{array}{r}3 \\
12\end{array}$ & $\begin{array}{r}\text { NIL } \\
5\end{array}$ & $\frac{\text { NIL }}{5}$ & $\begin{array}{r}\text { NIL } \\
2\end{array}$ & MIL & $\begin{array}{r}2 \\
11\end{array}$ & 53 & 100 \\
\hline Third cl. conc. & 30 & $\begin{array}{r}\text { NIL } \\
5\end{array}$ & $\begin{array}{l}2 \\
7\end{array}$ & $\begin{array}{r}\text { NIL } \\
2\end{array}$ & NIL & $\begin{array}{l}\text { NIL } \\
\text { NIL }\end{array}$ & $\begin{array}{l}\text { NIL } \\
\text { NIL }\end{array}$ & $\begin{array}{l}2 \\
8\end{array}$ & 66 & 100 \\
\hline First cl. tail & 49 & $\begin{array}{r}2 \\
21\end{array}$ & $\begin{array}{r}4 \\
24\end{array}$ & $\begin{array}{l}1 \\
9\end{array}$ & $\begin{array}{l}\text { NIL } \\
13\end{array}$ & NIL & $\underset{1}{\text { MIL }}$ & $\begin{array}{r}4 \\
16\end{array}$ & 40 & 100 \\
\hline Second $\mathrm{cl}$. tail & 44 & $\begin{array}{r}2 \\
17\end{array}$ & $\begin{array}{r}3 \\
18\end{array}$ & NIL & $\begin{array}{l}1 \\
7\end{array}$ & NIL & $\begin{array}{r}\text { MIL } \\
2\end{array}$ & $\begin{array}{r}4 \\
15\end{array}$ & 46 & 100 \\
\hline Third cl. tail & 46 & $\begin{array}{r}2 \\
14\end{array}$ & $\begin{array}{r}4 \\
15\end{array}$ & $\begin{array}{l}1 \\
6\end{array}$ & $\begin{array}{l}1 \\
6\end{array}$ & NIL & $\begin{array}{r}\text { NIL } \\
2\end{array}$ & $\begin{array}{r}2 \\
13\end{array}$ & 44 & 100 \\
\hline
\end{tabular}


TABLE 47 (CONTINUED)

BALANCED DISTRIBUTION OF GALEMA NONG BINARY NOD TERMARY PARTICLES IN EACH STREAM OF VANGORDA ZINC CIRCUIT (UTX)

\begin{tabular}{|c|c|c|c|c|c|c|c|c|c|c|}
\hline Stream & $\begin{array}{l}\text { Ternary } \\
\text { Porticles }\end{array}$ & sid & otz & 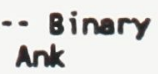 & $\begin{array}{l}\text { Part } \\
\text { Py }\end{array}$ & $\operatorname{leg}_{\text {Cp }} \cdots$ & Bar & sp & Free & Total \\
\hline Feed & 73 & $\begin{array}{r}1 \\
45\end{array}$ & $\begin{array}{l}\text { MIL } \\
10\end{array}$ & $\begin{array}{l}\text { NIL } \\
10\end{array}$ & $\begin{array}{c}1 \\
22\end{array}$ & $\begin{array}{r}\text { WIL } \\
2\end{array}$ & $\begin{array}{r}\text { MIL } \\
8\end{array}$ & 27 & 23 & 100 \\
\hline Ro. feed $1+k$ & 86 & $\begin{array}{r}1 \\
45\end{array}$ & NIL & NIL & $\begin{array}{r}1 \\
22\end{array}$ & ${ }_{3}{ }_{3}$ & ${ }_{7}^{\text {NIL }}$ & 27 & 10 & 100 \\
\hline Ro. conc. $l+k$ & 92 & $\begin{array}{r}1 \\
45\end{array}$ & $\begin{array}{l}\text { NIL } \\
\text { NIL }\end{array}$ & NIL & WIL & NIL & MIL & $3^{3}$ & 4 & 100 \\
\hline Ro. tail l+k & 84 & 4 & $\begin{array}{l}\text { NIL } \\
22\end{array}$ & MIL & $\begin{array}{c}1 \\
28\end{array}$ & ${ }_{3}^{\text {NIL }}$ & NIL & $\begin{array}{c}1 \\
19\end{array}$ & 13 & 100 \\
\hline Scav. conc. $1+k$ & 69 & $\begin{array}{r}1 \\
44\end{array}$ & ${ }_{13}^{\text {MIL }}$ & ${ }_{26}^{\text {NIL }}$ & $\begin{array}{r}1 \\
23\end{array}$ & $\begin{array}{r}\text { NIL } \\
8\end{array}$ & $\begin{array}{l}1 \\
3\end{array}$ & $\begin{array}{r}1 \\
28\end{array}$ & 27 & 100 \\
\hline Scav. tail l+k & 93 & $\begin{array}{r}1 \\
45\end{array}$ & $\begin{array}{l}\text { MIL } \\
26\end{array}$ & $\begin{array}{l}\text { NIL } \\
17\end{array}$ & $31^{2}$ & $\begin{array}{l}\text { NIL } \\
\text { WIL }\end{array}$ & $\begin{array}{r}\text { NIL } \\
9\end{array}$ & $\underset{16}{\text { NIL }}$ & 4 & 100 \\
\hline Reg. cyc. $w / f$ & 42 & $\begin{array}{r}1 \\
14\end{array}$ & $\begin{array}{l}\text { NIL } \\
\text { NIL }\end{array}$ & NIL & $\begin{array}{l}1 \\
5\end{array}$ & NIL & NIL & $\begin{array}{r}4 \\
12\end{array}$ & 52 & 100 \\
\hline Reg. discharge & 31 & $\begin{array}{r}1 \\
14\end{array}$ & $\begin{array}{l}\text { NIL } \\
\text { NIL }\end{array}$ & $\begin{array}{l}\text { NIL } \\
\text { NIL }\end{array}$ & $\begin{array}{l}2 \\
2\end{array}$ & $\begin{array}{l}\text { MIL } \\
\text { MIL }\end{array}$ & ${ }_{6}^{\text {NIL }}$ & $\begin{array}{l}4 \\
6\end{array}$ & 62 & 100 \\
\hline Reg. cyc. o/f & 41 & $\begin{array}{r}1 \\
12\end{array}$ & $\begin{array}{l}\text { NIL } \\
\text { MIL }\end{array}$ & ${ }_{6}^{\text {NIL }}$ & $\begin{array}{l}2 \\
6\end{array}$ & MIL & NIL & $\begin{array}{r}5 \\
18\end{array}$ & 51 & 100 \\
\hline Ro.conc. j & 42 & 11 & $\begin{array}{r}\text { NIL } \\
2\end{array}$ & NIL & $\begin{array}{l}1 \\
4\end{array}$ & $\begin{array}{l}\text { NIL } \\
\text { MIL }\end{array}$ & WIL & $\begin{array}{r}6 \\
25\end{array}$ & 50 & 100 \\
\hline Ro. tail j & 43 & $\begin{array}{r}1 \\
16\end{array}$ & $\begin{array}{r}\text { NIL } \\
2\end{array}$ & NIL & $\begin{array}{l}2 \\
8\end{array}$ & MIL & MIL & $\begin{array}{r}1 \\
15\end{array}$ & 53 & 100 \\
\hline Scav. conc. j & 41 & 14 & ${ }_{2}^{\text {NIL }}$ & NIL & $\begin{array}{l}1 \\
6\end{array}$ & NIL & NIL & $\begin{array}{r}2 \\
16\end{array}$ & 55 & 100 \\
\hline Scav. tail j & 50 & $\begin{array}{r}1 \\
23\end{array}$ & $\begin{array}{l}\text { NIL } \\
\text { NIL }\end{array}$ & NIL & $\begin{array}{r}4 \\
13\end{array}$ & NIL & $\mathrm{NIL}_{4}$ & ${ }_{11}^{\text {NIL }}$ & 45 & 100 \\
\hline Ro. col. conc. & 36 & $\begin{array}{l}1 \\
3\end{array}$ & $\begin{array}{l}\text { NIL } \\
\text { NIL }\end{array}$ & NIL & $\begin{array}{l}1 \\
1\end{array}$ & MIL & $\begin{array}{l}\text { NIL } \\
\text { NIL }\end{array}$ & $\begin{array}{r}8 \\
22\end{array}$ & 54 & 100 \\
\hline Ro. col. tail & 42 & $\begin{array}{c}1 \\
13\end{array}$ & $\begin{array}{r}\text { NIL } \\
2\end{array}$ & NIL & $\begin{array}{l}1 \\
5\end{array}$ & $\begin{array}{r}\text { NIL } \\
2\end{array}$ & $\begin{array}{r}\text { NIL } \\
2\end{array}$ & 22 & 52 & 100 \\
\hline Sc. col. conc. & 35 & MIL & $\begin{array}{l}\text { NIL } \\
\text { NIL }\end{array}$ & NIL & WIL & $\begin{array}{r}\text { NIL } \\
2\end{array}$ & $\begin{array}{l}\text { NIL } \\
\text { NIL }\end{array}$ & $\begin{array}{r}8 \\
23\end{array}$ & 57 & 100 \\
\hline scav. col. tail & 42 & $\begin{array}{r}1 \\
13\end{array}$ & $\begin{array}{r}\text { NIL } \\
2\end{array}$ & ${ }_{6}^{\text {NIL }}$ & $\begin{array}{l}1 \\
5\end{array}$ & $\frac{\text { MIL }}{2}$ & ${ }_{3}^{\text {NIL }}$ & 22 & 52 & 100 \\
\hline Zine conc. & 36 & $\begin{array}{l}1 \\
3\end{array}$ & $\begin{array}{l}\text { NIL } \\
\text { NIL }\end{array}$ & NIL & $\begin{array}{r}\text { WIL } \\
2\end{array}$ & WIL & $\begin{array}{l}\text { NIL } \\
\text { NIL }\end{array}$ & $\begin{array}{r}8 \\
23\end{array}$ & 55 & 100 \\
\hline Final tail & 77 & 37 & ${ }_{17}^{\text {NIL }}$ & $\underset{15}{\text { MIL }}$ & 25 & $\begin{array}{l}\text { NIL } \\
\text { NIL }\end{array}$ & NIL & ${ }_{13}^{\text {NIL }}$ & 19 & 100 \\
\hline
\end{tabular}

- The distribution of the ternaries, given in the second line for each stream, does not sum to $100 \%$. 
TABLE 48

NORMALIZED MINERAL ASSOCLATIONS IN VANGORDA CONCENTRATOR PRODUCTS (\%PERIMETER)

\begin{tabular}{|c|c|c|c|c|c|c|c|}
\hline \multicolumn{8}{|c|}{ FINAL LEAD CONCENTRATE } \\
\hline \multicolumn{8}{|c|}{ GALENA } \\
\hline QTZ & ANK & PY & $\mathbf{C P}$ & BAR & PO & SID & SP \\
\hline 1 & 2 & 6 & 2 & 4 & 2 & 16 & 67 \\
\hline \multicolumn{8}{|c|}{ SPHALERITE } \\
\hline QTZ & ANK & PY & $\mathbf{C P}$ & BAR & PO & SID & GAL \\
\hline 1 & 0 & 2 & 1 & 1 & 0 & 7 & 88 \\
\hline \multicolumn{8}{|c|}{ FINAL ZINC CONCENTRATE } \\
\hline \multicolumn{8}{|c|}{ GALENA } \\
\hline QTZ & ANK & PY & $\mathbf{C P}$ & BAR & PO & SID & SP \\
\hline 0 & 1 & 5 & 1 & 1 & 1 & 15 & 76 \\
\hline \multicolumn{8}{|c|}{ SPHALERITE } \\
\hline QTZ & ANK & PY & $\mathbf{C P}$ & BAR & PO & SID & GAL \\
\hline 1 & 3 & 11 & 5 & 3 & 2 & 51 & 24 \\
\hline \multicolumn{8}{|c|}{ FINAL TAILINGS } \\
\hline \multicolumn{8}{|c|}{ GALENA } \\
\hline QTZ & ANK & PY & $\mathrm{CP}$ & BAR & PO & SID & SP \\
\hline 17 & 5 & 49 & 2 & 5 & 4 & 10 & 8 \\
\hline \multicolumn{8}{|c|}{ SPHALERITE } \\
\hline QTZ & ANK & PY & $\mathbf{C P}$ & BAR & PO & SID & GAL \\
\hline 5 & 1 & 30 & 11 & 23 & 4 & 11 & 15 \\
\hline
\end{tabular}

indicates that the galena and siderite report to the zinc concentrate by locking with sphalerite. Both sphalerite and galena lost to the final tailings are mostly locked with pyrite and the carbonates. Again, the perimeter technique highlights very well the deleterious effect the association of sphalerite, galena and the carbonates in the unbroken ore has on grade and recovery.

The perimeter association technique also gives an alternate measurement of 
mineral liberation, as the percentage of mineral perimeter which is exposed or free. The magnitude of the relative changes in the percentage free with sieve size in the lead circuit feed for sphalerite and galena shows that at the grind achieved in the feed sphalerite is close to its optimum grind whereas that of galena is not (Appendix 21).

A comparison of the variations between streams of percent free on a perimeter $\%$ basis versus a weight $\%$ basis shows that there is general agreement in the trends (Figure 57). It is significant that the differences are largest for sphalerite in the lead concentrate. This indicates, again in similar fashion to the Faro ore, that a considerable amount of locked sphalerite with large areas of exposed surface is being lost to the lead concentrate. Similarly, galena lost to the zinc concentrate and final tailings has a high percentage of exposed perimeter.

Distribution of binary particles

The effect on ore mineral recovery by locking with each of the other gangue minerals is shown in Table 49. For the lead circuit the data show that the chances of a binary galena particle being recovered is best if it is locked with quartz $(75 \%)$, followed by sphalerite, pyrite and siderite. Distribution of binary particles of sphalerite to the lead concentrate is highest for those locked with galena. For the zinc circuit distribution of binary particles containing galena to the zinc concentrate is highest for those containing sphalerite. Recovery of sphalerite in binary particles is highest for those locked with galena $(95 \%)$. 


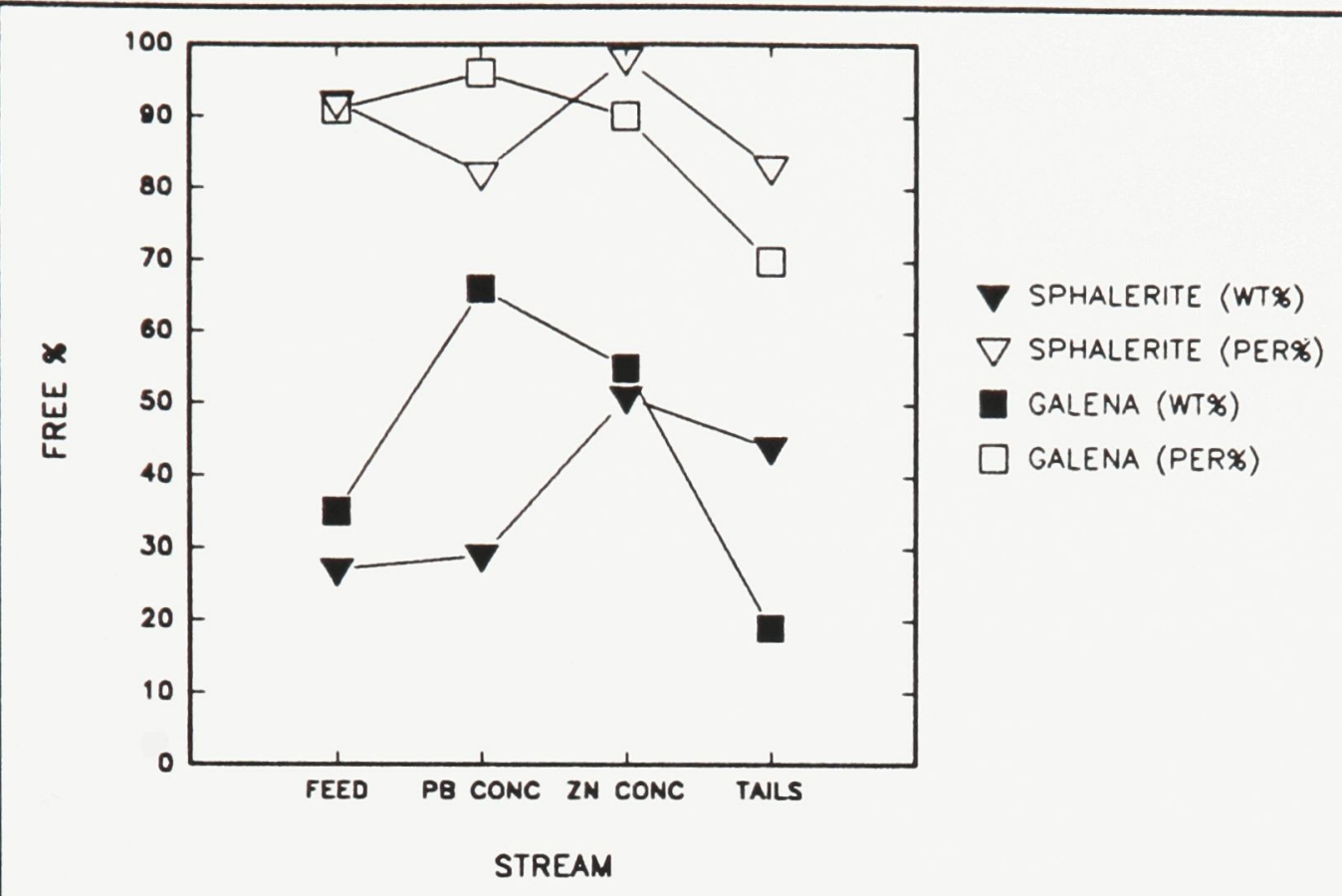

Figure 57 Comparison of percent free by wt\% versus perimeter\% of sphalerite and galena in selected streams of Vangorda concentrator.

Encapsulated ore minerals

The quantities of ore minerals encapsulated in the various gangue minerals in the final concentrator tailings were measured (Table 50). The data show that encapsulation is not a significant factor in lead and zinc losses to the tailings.

Mineral associations of gangue minerals in the final lead and zinc concentrates

The determination of the nature of the gangue minerals reporting to the lead and zinc concentrates was determined in the same manner as for the Faro ore. The data are shown in Table 51.

Associations of sphalerite and galena in the lead flotation circuit

Data in Table 47 show that most of the galena lost to the lead scavenger tails G+H 
TABLE 49

FLONRATES AND DISTRIBUTIONS TO CONCENTRATES OF GALEMA AND SPHALERITE LOCKED IN BINARY PARTICLES

\begin{tabular}{|c|c|c|c|}
\hline \multicolumn{4}{|c|}{ VANGORDA LEAD FLOTATION CIRCUIT } \\
\hline \multicolumn{2}{|c|}{ Galena Flowrates (tph) } & \multicolumn{2}{|c|}{ Galena Distribution $(x)$} \\
\hline Type of binary & Lead Conc. & Lead Tails. & Lead Conc. \\
\hline \multirow[t]{2}{*}{$\begin{array}{l}\text { Gal-Siderite } \\
\text { Gal-Quartz } \\
\text { Gal-Pyrite } \\
\text { Gal-Chalcopyrite } \\
\text { Gal-Barite } \\
\text { Gal-Sphalerite }\end{array}$} & $\begin{array}{l}0.07 \\
0.24 \\
0.05 \\
0.00 \\
0.00 \\
0.29\end{array}$ & $\begin{array}{l}0.07 \\
0.08 \\
0.04 \\
0.03 \\
0.02 \\
0.17\end{array}$ & $\begin{array}{r}50 \\
75 \\
56 \\
0 \\
0 \\
63\end{array}$ \\
\hline & Flowrates (tph) & \multicolumn{2}{|c|}{ Sphalerite Distribution $(x)$} \\
\hline Type of binary & Lead Conc. & Lead Tails & Lead Conc. \\
\hline $\begin{array}{l}\text { Sp-Siderite } \\
\text { Sp-Quartz } \\
\text { Sp-Pyrite } \\
\text { Sp-Chal copyrite } \\
\text { Sp-Barite } \\
\text { Sp-Galena }\end{array}$ & $\begin{array}{l}0.00 \\
0.00 \\
0.00 \\
0.00 \\
0.00 \\
0.39\end{array}$ & $\begin{array}{l}0.34 \\
0.43 \\
0.09 \\
0.43 \\
0.01 \\
0.16\end{array}$ & $\begin{array}{r}0 \\
0 \\
0 \\
0 \\
0 \\
71\end{array}$ \\
\hline
\end{tabular}

VANGORDA ZINC FLOTATION CIRCUIT

Galena Flowrates (tph)

Galena Distribution (x)

Type of binery

Zinc Conc.

Zine Tails.

zinc Conc.

Gal-siderite

Gal-Quartz

0.02

0.00

0.04

0.01

0.00

Gal-Chal copyrite

0.00

0.00

0.11

0.00

Gal-Barite

0.17

0.00

0.01

33

8

8

94

Sphalerite Flowrates (tph) Sphalerite Distribution (X)

Type of binary Zinc Conc. Zinc Tails. Zinc Conc.

$\begin{array}{lllr}\text { Sp-Siderite } & 0.15 & 0.10 & 60 \\ \text { Sp-Quartz } & 0.00 & 0.02 & 0 \\ \text { Sp-Pyrite } & 0.02 & 0.01 & 66 \\ \text { Sp-Chalcopyrite } & 0.11 & 0.09 & 55 \\ \text { Sp-Barite } & 0.00 & 0.05 & 0 \\ \text { Sp-Galena } & 0.42 & 0.02 & 95\end{array}$


TABLE 50

DISTRIBUTION OF SPHALERTE AND GALENA IN FREE, EXPOSED AND ENCAPSULATED GRAINS IN VANGORDA FINAL TAILINGS (WT\%)

\begin{tabular}{|c|c|c|c|}
\hline MINERAL & FREE & EXPOSED & $\begin{array}{c}\text { ENCAPSULA } \\
\text { TED }\end{array}$ \\
\hline \multicolumn{4}{|c|}{$+53 \mu \mathrm{M}$ Sieve Fraction } \\
\hline SPHALERTTE & 32 & 67 & 1 \\
\hline GALENA & 7 & 81 & 12 \\
\hline \multicolumn{4}{|c|}{$+38 \mu \mathrm{M}$ Sieve Fraction } \\
\hline SPHALERTTE & 23 & 75 & 2 \\
\hline GALENA & 11 & 79 & 10 \\
\hline \multicolumn{4}{|c|}{$-38 \mu \mathrm{M}$ Sieve Fraction } \\
\hline SPHALERITE & 54 & 42 & 4 \\
\hline GALENA & 30 & 68 & 2 \\
\hline \multicolumn{4}{|c|}{ OVERALL } \\
\hline SPHALERTE & 44 & 54 & 2 \\
\hline GALENA & 19 & 74 & 7 \\
\hline
\end{tabular}

banks is associated with siderite. Galena lost to the I bank scavenger tails is mostly associated with quartz (38\%) and siderite (34\%). Most of the sphalerite distributed to the rougher concentrates of the G,H I banks is locked with galena (Table 46).

In all the streams of the lead cleaner circuit the galena is mostly attached to sphalerite, quartz and siderite (Table 47). Approximately $58 \%$ of the sphalerite in the final lead concentrate is attached to galena and another $29 \%$ is free (Table 46). Data in Table 51 show that sphalerite locked with galena is the major contaminant in the final lead concentrate. 
TABLE 51

DISTRIBUTION OF DILUENT MINERALS IN VANGORDA CONCENTRATES (WT\% OF SAMPLE)

\begin{tabular}{|c|c|c|c|c|}
\hline \multicolumn{5}{|c|}{ LEND CONCENTRATE } \\
\hline MINERAL & $\begin{array}{c}\text { Locked with } \\
\text { galena but } \\
\text { not } \\
\text { sphalerite }\end{array}$ & $\begin{array}{l}\text { Locked with } \\
\text { sphalerite } \\
\text { but not } \\
\text { golena }\end{array}$ & $\begin{array}{c}\text { Locked with } \\
\text { both }\end{array}$ & $\begin{array}{l}\text { Free or } \\
\text { locked with } \\
\text { neither }\end{array}$ \\
\hline Quartz & 0.96 & 0.17 & 0.34 & 1.26 \\
\hline Ankerite & 0.57 & 0.12 & 0.20 & 1.13 \\
\hline Pyrite & 1.63 & 0.77 & 0.85 & 1.40 \\
\hline Chal copyrite & 0.01 & 0.02 & 0.00 & 0.04 \\
\hline Barite & 0.13 & 0.08 & 0.10 & 0.23 \\
\hline Pyrrhotite & 0.91 & 0.03 & 0.60 & 0.76 \\
\hline Sphalerite & 6.87 & $3.20^{\circ}$ & $\ldots$ & 0.89 \\
\hline siderite & 1.99 & 0.49 & 0.70 & 1.62 \\
\hline \multicolumn{5}{|c|}{ ZINC CONCENTRATE } \\
\hline Quartz & 0.04 & 0.31 & 0.02 & 0.11 \\
\hline Ankerite & 0.03 & 0.37 & 0.04 & 0.33 \\
\hline Pyrite & 0.37 & 2.46 & 0.04 & 2.08 \\
\hline Chal copyrite & 0.00 & 1.83 & 0.05 & 0.76 \\
\hline Barite & 0.00 & 0.35 & 0.03 & 0.25 \\
\hline Pyrrhotite & 0.01 & 0.58 & 0.01 & 0.67 \\
\hline Galena & $2.88^{\circ}$ & 1.79 & $\cdots$ & 0.61 \\
\hline siderite & 0.17 & 1.58 & 0.37 & 1.28 \\
\hline
\end{tabular}

Free sphalerite

Free galena

Associations of sphalerite and galena in the zinc flotation circuit

Data in Table 46 show that $32 \%$ of the sphalerite lost to the scavenger tails $L+K$ banks is locked with quartz and $26 \%$ is locked with siderite. In the final tails $44 \%$ of the sphalerite is free.

The locked sphalerite in the $\mathrm{K}+\mathrm{L}$ bank rougher concentrate is mostly locked with 
siderite and surprisingly a significant amount is locked with chalcopyrite (Table 46). The galena in the combined zinc rougher concentrate is locked with both siderite and sphalerite in ternary particles (Table 47). Only $31 \%$ of the galena in the J bank rougher concentrate is locked with sphalerite most of it, $50 \%$, is free.

The locked galena portion in the final zinc concentrate is mostly attached to sphalerite but $55 \%$ is free.

Relationship between Metal Recovery and Grade and Mineralogy in Vangorda Ore Lead recovery and grade

The concentrator recovers only $66 \%$ of the lead at a grade of $63 \%$ (Appendix 19). The galena in the final lead concentrate is mostly "liberated" $(87 \%)$ and mostly free (66\%). The galena lost to the lead circuit tailings is $44 \%$ "liberated", $28 \%$ middling and $28 \%$ tailings which means a high proportion $(72 \%)$ of recoverable galena is being lost. This shows that the low lead recovery in the Vangorda circuit is mostly due to factors other than poor liberation.

The low lead recovery may result from the possible presence of significant amounts of lead ions in the slurry. The source of these ions may be due to the progressive oxidation of galena in the circuit or due to the presence of porous and secondary galena, goethite and pyrrhotite in Vangorda ore. These minerals are known to be reactive in water (Chryssoulis et al 1992, Wyslouzil and Salter 1990). Under suitable conditions they release iron and/or lead ions to the slurry which may react with the surfaces of galena grains ultimately reducing its flotation response. Furthermore, the presence of porous and 
secondary galena indicates that $\mathrm{PbSO}_{4}$ (anglesite) and $\mathrm{PbCO}_{3}$ (cerussite) may also be present as surface coatings on the galena. Both minerals have a very slow flotation response.

Another factor contributing to the loss of recoverable galena is its association with siderite, pyrite and sphalerite. In particular, galena is strongly associated with the carbonates, ankerite and siderite, in the lead circuit feed. Table 47 shows that about $50 \%$ of the galena in the lead tailings is associated with the carbonates. This association clearly adversely affects recovery of galena. Middling particles of galena which would normally be recycled to regrind and then liberated and recovered are lost to tailings due to locking with carbonates. The galena in the final tailings is also mostly locked with the carbonates. As already seen in the Faro concentrator, siderite is also very non-selective in the Vangorda concentrator.

Galena is very fine-grained, approximately $80 \%-26 \mu \mathrm{m}$ in the concentrator feed. which indicates that the ore must be ground extremely fine to liberate galena properly. The final grind is only $81 \%-19 \mu \mathrm{m}$, in the lead rougher cyclone overflow (Table 42). This resulted in considerable loss of galena, $56 \%$ not "liberated", to the lead circuit tails. Therefore the fineness of the galena is a factor affecting the recovery of lead in Vangorda ore.

Lead grade is strongly affected by locking of gangue minerals with galena. The amount of gangue minerals recovered in the lead concentrate by locking with galena is $7 \%$ sphalerite, $3 \%$ carbonate, and $2 \%$ pyrite (See Table 51 ).

Most surprising is the recovery of a large amount of minerals which are not locked 
with galena at all. Significantly, there is $3 \%$ free sphalerite and $9 \%$ other minerals, comprising $12 \%$ of the total lead concentrate. Furthermore, most of the sphalerite in the lead concentrate is "liberated" (Figure 44) so that misplaced minerals account for more dilution than minerals locked in high grade galena particles. The analysis of the recovery of galena locked in binary particles (Table 48) shows that the lead flotation circuit rejects galena locked in barite and chalcopyrite binaries better than galena locked in binaries of quartz, sphalerite and pyrite. This supports the suggestion that sphalerite and pyrite are being activated in the lead circuit, as noted previously for the Faro lead circuit, and possibly even quartz (Fuerstenau et al). It is also possible that the carbonates are also being activated (Gaudin 1939, Taggart 1945). Furthermore, the efficacy of the deactivating action of the cyanide (dosage $220 \mathrm{~g} / \mathrm{T}$ ) is being adversely affected due to the presence of the cyanicides: covellite, digenite, pyrrhotite and marcasite. Copper may be the main activator here because of the prevalence of secondary copper minerals not observed in the Faro ores.

Zinc recovery and grade

The relatively coarse grain size of sphalerite contributes to the relative ease of its liberation and recovery. However, the concentrator recovers only $77 \%$ of the zinc (Appendix 19) at a grade of $48.5 \%$. The sphalerite in the final zinc concentrate is mostly "liberated" (98\%). The sphalerite lost to the final tailings is $69 \%$ "liberated", $15 \%$ middling and $16 \%$ tailings which means a very high proportion of the sphalerite (84\%) in the final tailings is recoverable. Therefore poor liberation is not the main cause of zinc 
losses to tailings. As noted for the Faro circuit it is possible that the loss of "liberated" sphalerite to the final tails is due to a coating of oxidized lead and/or ferric iron on the sphalerite grains (Chryssoulis et al 1992).

The concentrator distributes $5.8 \%$ of the zinc to the lead concentrate. Most of the sphalerite in the lead concentrate is "liberated". Again, as noted for the Faro zinc circuit, it is possible that activation of sphalerite is occurring. In this case it is more likely to be due to copper because of the strong presence of secondary copper minerals particularly covellite.

In the tailings most of the locked sphalerite is locked with carbonates, quartz and pyrite but is not encapsulated.

The zinc grade is reduced mainly by gangue locked to sphalerite particles in the decreasing order pyrite, chalcopyrite, galena and siderite. Although the sphalerite has excellent liberation, the zinc grade is ultimately limited by the zinc content of the sphalerite (58.3\%). Significant amounts of galena, pyrite and carbonate not locked with sphalerite also contribute to dilution of the zinc grade.

Liberation of Silver-carrier minerals and Gold-silver

One polished section for each stream examined was subjected to an automatic silver search (See Methodology). Because of the general lack of silver and silver-carrier mineral grains in all the samples studied their liberation and association were not determined by image analysis but were estimated by locating and examining those grains found by the silver search. In the concentrator samples, 40 grains of tetrahedrite-tennantite 
were found of which 27 were found in the lead first cleaner tails. Of these $\mathbf{4 0}$ grains 26 were free and 14 locked, indicating a high overall degree of liberation. Only one free grain of acanthite was found in the lead concentrate. No silver nor silver-containing mineral grains were found in the final concentrator tailings.

The liberation of gold-carrier mineral grains in all the samples studied was also estimated. Only five grains of gold-silver alloy were found in the concentrator samples and they were all free, therefore liberation is assumed to be very high.

Associations of Silver and Gold Carrier Minerals

Fourteen locked grains of tetrahedrite-tennantite were found in the concentrator samples. Of these 9 were locked with galena as binary particles, six were locked with galena in the first cleaner tail and the other three were locked with galena in the lead concentrate. None was encapsulated. All gold carrier minerals were free.

Silver and Gold Distribution and Recovery

The mineralogical distribution of silver and gold in the Vangorda concentrator feed was determined by identifying the significant silver and gold carrier minerals, measuring their silver and gold contents and their abundance in each stream of the concentrator. Several samples taken from the concentrator, but also some from core, were subjected to a trace mineral search technique by means of the image analysis system to identify the significant silver and gold carrier minerals.

Electron microprobe analysis was used to measure the silver content of galena and 
gold-silver alloy in concentrator products and in tetrahedrite in core samples and gold content of the gold-silver alloy. SIMS analysis was used to determine the silver and gold content of the major sulphide minerals (Table 52).

Due to the scarcity of tetrahedrite-tennantite grains it was not practical to measure their quantity by means of the image analyzer. An attempt to determine the quantity of tetrahedrite-tennantite in the Vangorda feed indirectly by an Sb balance was not attempted due to the highly variable $\mathrm{Sb}$ content of the tetrahedrite-tennantite. Instead the quantity was estimated by taking the ratio of the number of tetrahedrite-tennantite grains found and the total number of particles examined in each sample. On the basis of the average modal analysis the average specific gravity of the ore was taken as 4.0 and that the average

\section{TABLE 52}

AVERAGE SILVER AND GOLD CONTENT OF SULPHIDE MINERALS IN VANGORDA ORE BY SIMS ANALYSIS

\begin{tabular}{|c|c|c|}
\hline MINERAL & $\begin{array}{c}\text { SILVER } \\
\text { CONTENT } \\
\text { (PPM) }\end{array}$ & $\begin{array}{c}\text { GOLD } \\
\text { CONTENT } \\
\text { (PPM) }\end{array}$ \\
\hline MARCASITE & 3.4 & 0.4 \\
\hline CHALCOPYRITE & 109 & 0.11 \\
\hline SPHALERTTE & 20 & nd \\
\hline PYRTTE & 2.2 & 0.10 \\
\hline PYRRHOTTTE & 0.85 & 0.30 \\
\hline GALENA & nd & 0.11 \\
\hline ARSENOPYRTTE & nd & 13 \\
\hline
\end{tabular}

nd not determined

particle size in the sample is the same as that of the tetrahedrite-tennantite grains.

Materials balances were performed to determine the silver and gold distributions 
in each sample of the concentrator and to improve the accuracy of the data (Table 53).

Independent determination of the quantity of gold, silver and silver-containing minerals in ore by cyanide leaching was performed (Chryssoulis and Cabri 1990). Because an adequate quantity of the concentrator feed was no longer available the sample tested was a composite of $4 \mathrm{G}$ core which closely represented the concentrator feed at the time of the sampling campaign. The results were used as confirmation of the precious metal distribution given in Table 53. The leach test showed that $59 \%$ of the $\mathrm{Ag}$ and $91 \%$ of the Au is "visible". This is comparable with $31 \%$ and $85 \%$ respectively as shown in Table 53.

Silver distribution and recovery

Recovery of silver by its host mineral was calculated on the basis of the total silver assay in each of the concentrator samples. Knowing the silver content of the silvercarrier minerals allows the distribution of the silver to be calculated. The balanced distribution of silver by host mineral is shown in Table 53. The silver distribution in Vangorda ore is given by the distribution found in the Vangorda concentrator feed. The data indicate that galena is the major silver carrier mineral followed by sphalerite, pyrite, chalcopyrite, marcasite and pyrrhotite. A large proportion of the silver (31.6\%) is unaccounted for. On the basis of the relative numbers of tetrahedrite, silver and goldsilver grains found in the concentrator and core samples it is estimated that the silver due to these species is insignificant to the total silver balance so they are included in the unknown group. 


\section{TABLE 53}

MINERALOGICAL DISTRIBUTION OF SILVER AMD GOLD IN SELECTED STREAMS OF VANGORDA CONCENTRATOR

\begin{tabular}{|c|c|c|c|c|c|}
\hline & & & SILVER & & \\
\hline & FEED & & LEA & & \\
\hline Mineral & พTT & DIST. & Mineral & WTX & DIST. \\
\hline $\begin{array}{l}\text { Galena } \\
\text { Marcasite } \\
\text { Chal copyrite } \\
\text { Sphalerite } \\
\text { Pyrite } \\
\text { Pyrrhotite } \\
\text { Unknown }\end{array}$ & $\begin{array}{r}63.3 \\
0.2 \\
0.9 \\
2.7 \\
1.2 \\
0.1 \\
31.6 \\
\cdots \cdots \\
100.0\end{array}$ & $\begin{array}{l}100.00 \\
100.00 \\
100.00 \\
100.00 \\
100.00 \\
100.00 \\
100.00\end{array}$ & $\begin{array}{l}\text { Galena } \\
\text { Marcasite } \\
\text { Chal copyrite } \\
\text { Sphalerite } \\
\text { Pyrite } \\
\text { Pyrrhotite } \\
\text { Unknown }\end{array}$ & $\begin{array}{c}96.2 \\
0.0 \\
0.1 \\
0.4 \\
0.0 \\
0.0 \\
3.3 \\
\ldots \ldots \\
100.0\end{array}$ & $\begin{array}{r}69.80 \\
0.49 \\
5.34 \\
6.89 \\
0.38 \\
0.40 \\
4.84\end{array}$ \\
\hline & ZINC & & Fin & AILS & \\
\hline Mineral & WTX & DIST. & Mineral & บाT & DIST. \\
\hline $\begin{array}{l}\text { Galena } \\
\text { Marcasite } \\
\text { Chal copyrite } \\
\text { Sphalerite } \\
\text { Pyrite } \\
\text { Pyrrhotite } \\
\text { Unknown }\end{array}$ & \begin{tabular}{r}
39.9 \\
0.0 \\
2.9 \\
17.0 \\
0.1 \\
0.0 \\
40.1 \\
\hdashline$\ldots$ \\
100.0
\end{tabular} & $\begin{array}{r}10.08 \\
1.17 \\
44.24 \\
75.32 \\
1.22 \\
1.15 \\
26.60\end{array}$ & $\begin{array}{l}\text { Galena } \\
\text { Marcasite } \\
\text { Chalcopyrite } \\
\text { Sphalerite } \\
\text { Pyrite } \\
\text { Pyrrhotite } \\
\text { Unknown }\end{array}$ & \begin{tabular}{c}
39.6 \\
.7 \\
1.6 \\
2.0 \\
4.4 \\
0.4 \\
51.3 \\
\hdashline.. \\
100.0
\end{tabular} & $\begin{array}{l}20.12 \\
98.34 \\
50.42 \\
17.79 \\
98.40 \\
98.45 \\
68.62\end{array}$ \\
\hline
\end{tabular}

- includes negligible amounts contained in tetrahedrite-tennantite, acanthite, gold-silver alloy, native silver.

GOLD

FEED LEAD CONC

$\begin{array}{lrrlrr}\text { Mineral } & \text { WT\% } & \text { DIST } & \text { Mineral } & \text { WTX } & \text { DIST. } \\ \text { Galena } & 0.7 & 100.00 & \text { Galena } & 1.7 & 66.57 \\ \text { Marcasite } & 2.4 & 100.00 & \text { Marcasite } & 0.0 & 0.35 \\ \text { Chalcopyrite } & 0.1 & 100.00 & \text { Chalcopyrite } & 0.0 & 3.19 \\ \text { Arsenopyrite } & 2.1 & 100.00 & \text { Arsenopyrite } & 0.3 & 3.89 \\ \text { Pyrite } & 5.4 & 100.00 & \text { Pyrite } & 0.1 & 0.42 \\ \text { Pyrrhotite } & 3.9 & 100.00 & \text { Pyrrhotite } & 0.1 & 0.51 \\ \text { Gold-silver } & 85.4 & 100.00 & \text { Gold-silver } & 97.8 & 32.34 \\ & -2.0 & & & 100.0 & \end{array}$

ZINC CONC

FIMAL TAILS

$\begin{array}{lcrlrr}\text { Mineral } & \text { WTX } & \text { DIST } & \text { Mineral } & \text { WTX } & \text { DIST. } \\ \text { Galena } & 0.7 & 10.95 & \text { Galena } & 0.2 & 22.48 \\ \text { Marcasite } & 0.3 & 1.13 & \text { Marcasite } & 3.3 & 98.52 \\ \text { Chalcopyrite } & 0.4 & 45.05 & \text { Chalcopyrite } & 0.1 & 51.76 \\ \text { Arsenopyrite } & 0.2 & 1.04 & \text { Arsenopyrite } & 2.8 & 95.07 \\ \text { Pyrite } & 0.6 & 1.13 & \text { Pyrite } & 7.4 & 98.45 \\ \text { Pyrrhotite } & 0.5 & 1.32 & \text { Pyrrhotite } & 5.4 & 98.17 \\ \text { Gold-silver } & 97.2 & 9.46 & \text { Gold-silver } & 80.9 & 58.20 \\ & \mathbf{1 0 .} & & & -100.0 & \end{array}$


Confirmation of the amount of visible silver in the Vangorda ore was attempted by a diagnostic leach of core samples. The results of the leach test gives $41 \%$ invisible silver which is compared to $68 \%$ derived from Table 53 . The discrepancy may be partially explained by the fact that up to $20 \%$ of the $\mathrm{Ag}$ in galena can be leached by $\mathrm{NaCN}$ under the leaching conditions used in the test (Wyslouzil and Salter 1990) and also the samples are not exactly identical to the actual feed. Nevertheless, the leach test confirms that the unknown portion is likely due to visible silver. This indicates that the unknown portion is most probably acanthite.

Most of the silver in galena is recovered in the lead concentrate. A small amount of silver is recovered in the zinc concentrate contained in sphalerite and chalcopyrite.

The lack of acanthite grains may be due to their being leached out by cyanide which is used to depress pyrite and sphalerite in the lead circuit. There is evidence that some of the leached silver is reprecipitated onto the surfaces of other sulphide minerals (Chryssoulis et al 1984).

In summary the most important factor affecting silver recovery is its distribution between visible (acanthite) and invisible (galena) portions. It is interpreted that the largest portion of the silver loss is due to dissolution of acanthite. It may be reprecipitated onto the surfaces of other sulphide gangue minerals which do not report to the lead concentrate. Another large proportion of the silver loss is due to loss of galena to the tailings. Therefore part of the silver loss is indirectly related to the fine grain size of the host galena. 
Gold distribution and recovery

Gold-silver alloy is the only gold mineral found in the Vangorda ore. Other goldbearing minerals identified by SIMS are: galena, marcasite, chalcopyrite, arsenopyrite, pyrite and pyrrhotite. The gold distribution in the ore, determined in the same manner as for silver, is given by the gold distribution in the concentrator feed in Table 53. The amount attributed to gold-silver alloy is found by difference between the balanced total gold stream assay and the invisible gold measured by SIMS.

Confirmation of this distribution was attempted by a diagnostic gold leach. The results of the leach test give $9 \%$ invisible gold which is comparable to $15 \%$ from Table 53. The discrepancy may be attributed to the fact that the samples are not exactly identical to the actual feed. The leach test confirms that the unknown portion is very likely visible and may be assigned to gold-silver alloy.

Recovery of the gold-bearing minerals was calculated on the basis of the total gold assay in each of the concentrator samples. The balanced distribution of gold and goldbearing minerals, shown in Table 53, show that gold-silver alloy is the major gold carrier. Only $32 \%$ of the gold-silver alloy is recovered in the lead concentrate. Most of it is lost to tailings in spite of the fact that all the gold grains observed were free and the usage of a gold collector in an attempt to recover it.

In summary the overriding factor affecting gold recovery is its distribution in goldsilver alloy. Gold losses to tailings are due to poor selectivity. 
Deleterious minerals

Aside from the presence of the highly undesirable minerals covellite, chalcocite, oxidized galena, secondary galena, pyrrhotite, marcasite and goethite there are other minerals which are known to form slime coatings on sulphide minerals thus rendering them non-selective. The minerals kaolinite, chlorite, and graphite, are all present, but in insufficient amounts in the samples studied to be detrimental to the metallurgy of Vangorda ore.

A summary of the mineralogical factors which affect metal recovery and grade in Vangorda ore is found in Table 54.

\section{TABLE 54}

MINERALOGICAL FACTORS WHICH AFFECT RECOVERY AND GRADE IN VANGORDA CONCENTRATOR

\begin{tabular}{|c|c|c|}
\hline & RECOVERY & GRADE \\
\hline LEAD & $\begin{array}{l}\text { Liberated galena lost to tailings (due to } \\
\text { presence of oxidized } \mathrm{Pb} \text { and/or ferric ions } \\
\text { from reactive secondary minerals?). } \\
\text { Galena lost to zinc circuit due to strong } \\
\text { association with carbonates. } \\
\text { Galena not liberated due to fine grain size. }\end{array}$ & $\begin{array}{l}\text { Presence of liberated sphalerite possibly due } \\
\text { to activation by secondary minerals. } \\
\text { Presence of locked sphalerite due to strong } \\
\text { association with galena. } \\
\text { Presence of non-selective siderite free of } \\
\text { galena. }\end{array}$ \\
\hline ZINC & $\begin{array}{l}\text { Liberated sphalerite lost to tailings (due to } \\
\text { presence of oxidized } \mathrm{Pb} \text { and/or ferric ions } \\
\text { from secondary minerals?) } \\
\text { Liberated sphalerite lost to lead conc. (due to } \\
\text { activation by ions from secondary minerals?) } \\
\text { Sphalerite lost to lead conc. locked with } \\
\text { galena due to strong association. }\end{array}$ & $\begin{array}{l}\text { Presence of pyrite, chalcopyrite, galena and } \\
\text { siderite locked with sphalerite due to } \\
\text { association. } \\
\text { Presence of free gangue including galena, } \\
\text { pyrite, and siderite. } \\
\text { Zinc content in sphalerite is } 58.3 \% \text {. }\end{array}$ \\
\hline SILVER & $\begin{array}{l}\text { Silver in acanthite lost due to dissolution in } \\
\text { cyanide. } \\
\text { Silver in galena lost to tailings. }\end{array}$ & \\
\hline GOLD & Gold-silver alloy non-selective. & \\
\hline
\end{tabular}




\section{CHAPTER 8}

\section{SUMMARY AND CONCLUSIONS}

The contributions of this thesis are:

(1) Development of a method for measuring mineral associations in broken and unbroken ore and for determining relative bond strengths between mineral grains.

(2) The effect of mineralogy on the grade and recovery of metal from the ores of the Anvil District.

A. Method for determining associations and bond strengths between mineral grains 1. By measuring mineral grain perimeters in unbroken ore the following can be determined:

a) association between mineral pairs - a textural parameter and a basis for determining preferred breakage and relative bond strength when measured in conjunction with $2 \mathrm{a}$,

b) size association between mineral pairs - a textural parameter, and

c) preferred association between mineral pairs - a textural parameter.

2. By measuring mineral grain perimeters in composite particles in broken ore the following can be determined:

a) association between mineral pairs - a basis for determining preferred breakage and relative bond strength,

b) preferred breakage and relative bond strength when compared to 1 (a), and

c) per cent of mineral perimeter that is free. 
B. The effect of mineralogy on the grade and recovery of metal from the ores of the Anvil District.

The important mineralogical factors that were found are:

1. The presence of deleterious minerals, covellite, chalcocite, digenite, marcasite, porous and secondary galena, goethite, and pyrrhotite have a strong effect on grade and recovery of lead and zinc. In the case of Vangorda ore oxidized galena, covellite, chalcocite and digenite render the ore minerals partially non-selective, whereas marcasite, porous and secondary galena, goethite and pyrrhotite increase ore mineral rejection. The net effect is a significant loss of grade and recovery.

2. The grain size distributions of the minerals in the unbroken ore affect metallurgical performance because they have a direct effect on mineral liberation and associations in the plant. The assemblage of coarse-grained pyrite and comparatively fine-grained ore minerals prolongs the grinding time to liberate the ore minerals. The presence of much fine-grained galena results in a low liberation and resultant lead losses through locking. In contrast the presence of much coarse-grained sphalerite, tetrahedrite and gold-silver alloy yields a high liberation for each of those minerals.

3. The associations of the ore minerals influence their liberation and their subsequent behaviour in locked particles in the concentrator. Significant observations are that siderite is not easily detached from sphalerite and galena and that sphalerite and galena are not easily detached from each other. In contrast, barite and pyrite are more readily detached 
from sphalerite and galena. Furthermore the detachment is enhanced by the recycling action of the hydrocyclone which tends to redirect heavy barite- and coarse pyrite-bearing particles to the regrind whereas the lighter siderite-bearing particles pass by. The behaviour of the carbonates, siderite in particular, in the concentrator indicates they tend to be non-selective and possibly they may be being activated during processing. Ore minerals locked with siderite are therefore also rendered non-selective. The close association of sphalerite and galena in combination with their relatively low mutual detachment leads to a significant mutual misplacement to the wrong concentrate.

4. The mineralogical distribution of silver and gold is the major factor affecting the recovery of those metals. The recovery of silver in the Faro and Vangorda ores is mainly dependent on the behaviour of the main silver-bearing mineral, galena. Silver contained in acanthite and tetrahedrite, which are both most probably well liberated, was not recovered from both the Faro and Vangorda ores. Gold, mainly present as liberated, "visible" gold, has a poor recovery in both ores. 
A Comparison of the Metallurgical Characteristics of Faro and Vangorda Ores

Characteristics which facilitate processing of Faro ore are:.

1. Faro has negligible secondary minerals. In contrast the Vangorda ore contains some secondary minerals which cause loss of selectivity.

2. Faro ore is much coarser-grained than Vangorda. Galena and sphalerite are finergrained in Vangorda thus requiring a finer grind to liberate. A finer target grind implies increased sliming and lower liberation.

3.. Galena in Faro ore contains more silver than galena in Vangorda ore resulting in better silver recovery.

4. Faro tetrahedrite contains more silver. Any tetrahedrite which could be recovered in the lead concentrate will result in increased $\mathrm{Ag}$ recovery.

Characteristics which facilitate processing of Vangorda ore are:

1. Pyrite is fine-grained in Vangorda ore which means it takes less energy to liberate.

2. Sphalerite has more zinc in Vangorda ore which allows a higher zinc concentrate grade.

3.Vangorda has more barite which results in increased detachment of sphalerite and galena (better liberation) and better behaviour in the concentrator.

4. Vangorda has a lower carbonate content in particular it contains less siderite. 
Other salient points which have arisen as a result of this study are:

1. The change in the relative amounts of intergranular surface between the ore minerals and the gangue minerals in the unground versus the ground ore is strong evidence that preferred breakage is taking place.

2. The likelihood of breakage of intergranular bonds is related to the relative sizes of the minerals, the roughness of the intergranular surfaces and the mineral species which form the bonds. There is evidence that coarse-grained pyrite and barite break preferentially from sphalerite and galena. Evidence that another factor (or factors) besides grain size and surface roughness may affect breakage is seen by comparing mediumgrained siderite which detaches poorly from sphalerite and galena and coarse-grained barite which detaches readily. Both siderite and barite grains have comparable surface irregularities.

A sequence of preferential breakage between mineral pairs is proposed which is related to the strength of their bonds. Barite breaks away from sphalerite and galena best, followed by pyrite from sphalerite and galena, then sphalerite and galena from each other and lastly siderite from sphalerite and galena. This sequence is followed by, and undoubtedly overlapped by, a sequence of random breakage according to individual mineral crushing strength, which is predominantly related to mineral hardness, grain size and cleavability.

3. The measurement of associations by perimeter in the unbroken ore show that sphalerite and galena are associated with the other minerals according to the ore modality. 
Furthermore the data show that they are preferentially associated with the predominant gangue mineral in each ore type. In particular in Anvil ores, sphalerite and galena are preferentially associated with pyrite in pyritic ores, with quartz in quartzose ores, and with barite in baritic ores.

4. The associations by grain size in the unbroken ore has enabled quantification of textural trends not noticed by optical examination. In quartzose ores a significant proportion of sphalerite and galena is disseminated as fine grains. In pyritic and baritic ores coarse-grained sphalerite and galena have a higher association than their fine-grained counterparts. In those same ores fine-grained galena is more closely associated with pyrite than coarse-grained galena. In $4 G$ ore, the deleterious association of fine-grained sphalerite and galena with siderite is detected.

5. The characterization of the liberation and association of gangue minerals is important because it indicates their effect on grade and recovery. The determination of the recovery of the ore minerals locked with the different gangue minerals in binary particles elucidates the effect mineral associations have on ore mineral recovery. Clearly the mutual association of sphalerite and galena is detrimental to grade and recovery in both concentrators. Furthermore, in the zinc circuits of both concentrators binary particles of sphalerite with chalcopyrite, pyrite and siderite tend to be recovered in the zinc concentrate. In contrast binaries of sphalerite and barite are completely rejected. In the Vangorda lead circuit binaries of galena and quartz are recovered in the lead concentrate indicating possibly activation of quartz. Also those data indicate gangue mineral floatability by direct comparison of their recoveries. The detrimental behaviour of siderite 
has not been reported in the literature before in processing of base metal ores.

The liberation of the gangue minerals in the concentrates shows how grade is affected and highlights whether locking is significant. In the lead concentrates dilution is mainly caused by sphalerite locked with galena whereas in the zinc concentrates dilution is mainly caused by free galena. Furthermore gangue free of both sphalerite and galena is a major diluent in all concentrates.

Recommendations for improved lead, zinc and silver recovery and grade in Faro ore 1. The data show that the optimum grind for galena recovery has not been reached and that the lead regrind circuit does not significantly increase galena liberation. Therefore it is suggested the lead first cleaner tails (galena "liberation' $=40 \%$ ) be reground rather than the lead rougher concentrate (galena "liberation" $=78 \%$ ). This will increase the chances of locked galena particles being liberated. The regrind product may be floated in a scavenger.

2. The lead scavenger concentrate should be rerouted to the regrind mill. Galena liberation is only $54 \%$ in the scavenger concentrate compared to $77 \%$ in the lead rougher feed. This indicates a large amount of middling galena present in the scavenger concentrate which should be reground before being refloated.

3. Siderite is a major diluent of the lead and zinc concentrates. This indicates that it is not being rejected efficiently and may be activating in the lead circuit. The use of a depressant specifically for siderite should be investigated. 
Recommendations for improved lead, zinc, silver and gold recovery and grade in Vangorda ore

1. Due to the friable nature of the weathered portions of Vangorda ore, the secondary minerals are concentrated in the fine fractions. These minerals may be partially eliminated by screening and discarding the fine fraction at the pit prior to trucking the ore to the concentrator. The success of this operation is a key to processing of Vangorda ore.

2. The carbonates, siderite and ankerite, are major diluents of both concentrates. The use of a depressant for the carbonates should be investigated.

3. The recycling action of free gold-silver alloy in the regrind circuits indicates that gold recovery by gravity methods is possible. Also optimization of gold collector reagents should be investigated.

Recommendations for further work

1. The sequence of preferred breakage should be determined for other base metal ores especially to determine if metamorphic grade is a factor. Preferred breakage should be compared for a given ore between laboratory and industrial grinding mills.

2. The nature of the intergranular surface between locked particles of different mineral pairs in base metal ores should be examined to see how important surface roughness is.

3. The characteristics of the carbonates (grain sizes versus associations versus surface roughness) should be examined in various plant products (i.e. concentrates versus 
tailings) of Faro and Vangorda ores.

4. An investigation into the reasons for losses of liberated sphalerite and galena to the wrong concentrate and tails by examination of the surfaces of sphalerite and galena particles may indicate a reason for loss of selectivity in the Anvil ores. 


\section{APPENDIX 1}

\section{SULPHIDE LITHOLOGIC CODE*}
A Sulphide-bearing, ribbon-banded, graphitic quartzite
B Pyrite-free quartzite (may contain base metal sulphides)
C Base metal-poor, pyritic quartzite
D Base metal-bearing pyritic quartzite
E Massive pyritic sulphides, $>50 \%$ total sulphides
F Buckshot facies, E- type pyritic sulphides with very coarse- grained pyrite
G Baritic facies, massive pyritic sulphides and sulphates (more than $10 \% \mathrm{BaSO}_{4}$ )
H Pyrrhotitic facies, $>50 \%$ total sulphides

These codes are used in conjunction with a numerical prefix. "2" refers to Faro orebody, "4" refers to Vangorda orebody. Code adopted from Curragh Resources. 


\section{APPENDIX 2}

\section{FARO DRILLCORE ORE SAMPLES}

VERTICAL CROSS SECTION 120

DDH DEPTH ORETYPE

(ft.)

$\begin{array}{lll}86 \mathrm{~F}-11 & 165.5 & 2 \mathrm{G} \\ 86 \mathrm{~F}-11 & 200.0 & 2 \mathrm{E} \\ 86 \mathrm{~F}-11 & 219.0 & 2 \mathrm{E} \\ 86 \mathrm{~F}-11 & 225.9 & 2 \mathrm{E} \\ 86 \mathrm{~F}-11 & 246.3 & 2 \mathrm{G} \\ 86 \mathrm{~F}-11 & 258.0 & 2 \mathrm{E} \\ 86 \mathrm{~F}-11 & 279.3 & 2 \mathrm{E} \\ 86 \mathrm{~F}-11 & 298.6 & 2 \mathrm{~A} \\ 86 \mathrm{~F}-11 & 311.2 & 2 \mathrm{D} \\ & & \\ 86 \mathrm{~F}-12 & 186.4 & 2 \mathrm{E} \\ 86 \mathrm{~F}-12 & 191.6 & 2 \mathrm{C} \\ 86 \mathrm{~F}-12 & 211.3 & 2 \mathrm{G} \\ 86 \mathrm{~F}-12 & 270.2 & 2 \mathrm{~A} \\ 86 \mathrm{~F}-12 & 285.8 & 2 \mathrm{E} \\ 86 \mathrm{~F}-12 & 291.8 & 2 \mathrm{G} \\ 86 \mathrm{~F}-12 & 295.9 & 2 \mathrm{~F} \\ 86 \mathrm{~F}-12 & 328.6 & 2 \mathrm{E} \\ 86 \mathrm{~F}-12 & 380.9 & 2 \mathrm{D} \\ 86 \mathrm{~F}-12 & 426.7 & 2 \mathrm{~A} \\ & & \\ 86 \mathrm{~F}-19 & 118.0 & 2 \mathrm{E} \\ 86 \mathrm{~F}-19 & 139.0 & 2 \mathrm{C} \\ 86 \mathrm{~F}-19 & 154.0 & 2 \mathrm{E} \\ 86 \mathrm{~F}-19 & 165.7 & 2 \mathrm{D} \\ 86 \mathrm{~F}-19 & 190.5 & 2 \mathrm{~A} \\ 86 \mathrm{~F}-19 & 193.0 & 2 \mathrm{D} \\ 86 \mathrm{~F}-19 & 200.3 & 2 \mathrm{D}\end{array}$

VERTICAL CROSS SECTION 128 DDH DEPTH

(ft.)

$\begin{array}{lll}87 \mathrm{~F}-09 & 303.5 & 2 \mathrm{E} \\ 87 \mathrm{~F}-09 & 320.5 & 2 \mathrm{E} \\ 87 \mathrm{~F}-09 & 331.5 & 2 \mathrm{D} \\ 87 \mathrm{~F}-09 & 336.5 & 2 \mathrm{E} \\ 87 \mathrm{~F}-09 & 386.0 & \text { 2E } \\ 87 \mathrm{~F}-09 & 399.8 & \text { 2D } \\ 87 \mathrm{~F}-09 & 404.0 & 2 \mathrm{C} \\ 87 \mathrm{~F}-09 & 409.7 & 2 \mathrm{~B}\end{array}$

$87 \mathrm{~F}-11 \quad 67.0 \quad 2 \mathrm{G}$

$87 \mathrm{~F}-11 \quad 86.0 \quad 2 \mathrm{G}$

$87 \mathrm{~F}-11 \quad 95.7 \quad 2 \mathrm{E}$

87F-11 $103.1 \quad 2 \mathrm{E}$

$87 \mathrm{~F}-11 \quad 147.6 \quad 2 \mathrm{D}$

$87 \mathrm{~F}-11 \quad 156.5 \quad 2 \mathrm{E}$

$87 \mathrm{~F}-11 \quad 182.2 \quad 2 \mathrm{E}$

87F-11 $194.4 \quad 2 \mathrm{E}$

$87 \mathrm{~F}-11 \quad 218.7 \quad 2 \mathrm{~B}$

$\begin{array}{lll}87 \mathrm{~F}-11 & 229.8 & 2 \mathrm{D}\end{array}$

87F-11 $235.7 \quad 2 \mathrm{H}$

$87 \mathrm{~F}-11 \quad 243.9 \quad 2 \mathrm{E}$

$87 \mathrm{~F}-11 \quad 258.1 \quad 2 \mathrm{~A}$

$87 \mathrm{~F}-11 \quad 267.0 \quad 2 \mathrm{D}$

$87 \mathrm{~F}-11 \quad 288.1 \quad 2 \mathrm{~A}$ 
APPENDIX 3

COMPOSITION OF SPHALERITE IN FARO ORE (WTX)

\begin{tabular}{|c|c|c|c|c|c|c|c|c|c|c|c|}
\hline and. & $2 n$ & Fe & $m n$ & $\mathbf{S}$ & total & anal. & $2 n$ & $\mathrm{Fe}$ & Mn & $\boldsymbol{s}$ & total \\
\hline $\begin{array}{l}1 \\
2 \\
3 \\
4 \\
5 \\
6 \\
7 \\
8 \\
9 \\
10 \\
11 \\
12 \\
13 \\
14 \\
15 \\
16 \\
17 \\
18 \\
19 \\
20 \\
21 \\
22 \\
23 \\
24 \\
25 \\
26 \\
27 \\
28 \\
29 \\
30 \\
31 \\
32 \\
33 \\
34 \\
35 \\
36 \\
37 \\
38\end{array}$ & $\begin{array}{l}58.7 \\
56.8 \\
54.5 \\
54.4 \\
55.2 \\
55.3 \\
55.1 \\
59.4 \\
59.7 \\
56.6 \\
52.7 \\
54.1 \\
54.0 \\
57.2 \\
54.9 \\
54.6 \\
53.3 \\
59.5 \\
52.9 \\
54.1 \\
54.7 \\
54.2 \\
54.1 \\
55.6 \\
56.3 \\
56.4 \\
56.2 \\
54.1 \\
55.3 \\
50.9 \\
56.9 \\
54.8 \\
55.5 \\
55.4 \\
55.9 \\
53.0 \\
59.5 \\
55.2\end{array}$ & $\begin{array}{r}7.7 \\
9.4 \\
10.4 \\
10.3 \\
10.1 \\
10.0 \\
9.9 \\
7.2 \\
7.0 \\
9.4 \\
10.8 \\
10.4 \\
9.9 \\
8.5 \\
10.2 \\
10.6 \\
10.5 \\
7.9 \\
10.1 \\
10.0 \\
10.7 \\
10.3 \\
9.7 \\
9.5 \\
9.7 \\
8.4 \\
8.7 \\
10.4 \\
10.6 \\
11.1 \\
8.8 \\
9.3 \\
9.1 \\
9.1 \\
9.0 \\
10.6 \\
6.5 \\
9.3\end{array}$ & \begin{tabular}{l}
0.1 \\
0.1 \\
0.6 \\
0.6 \\
0.4 \\
1.6 \\
1.5 \\
0.2 \\
0.1 \\
0.7 \\
2.5 \\
1.8 \\
2.0 \\
0.3 \\
1.8 \\
0.5 \\
2.3 \\
0.1 \\
1.9 \\
1.5 \\
1.1 \\
1.2 \\
1.5 \\
1.9 \\
0.1 \\
0.4 \\
\hdashline
\end{tabular} & $\begin{array}{l}34.2 \\
33.0 \\
33.1 \\
33.6 \\
33.6 \\
33.7 \\
33.5 \\
33.6 \\
33.1 \\
33.4 \\
33.7 \\
33.6 \\
33.6 \\
33.7 \\
33.5 \\
33.5 \\
33.3 \\
34.0 \\
33.5 \\
33.4 \\
33.5 \\
33.8 \\
33.6 \\
34.5 \\
33.6 \\
33.3 \\
34.4 \\
33.5 \\
33.6 \\
33.7 \\
33.4 \\
33.3 \\
33.4 \\
33.7 \\
33.5 \\
33.6 \\
33.4 \\
33.6\end{array}$ & $\begin{array}{r}100.7 \\
99.3 \\
98.6 \\
98.9 \\
99.3 \\
100.6 \\
100.0 \\
100.4 \\
99.9 \\
100.1 \\
99.7 \\
99.9 \\
99.5 \\
99.7 \\
100.4 \\
99.2 \\
99.4 \\
101.5 \\
98.4 \\
99.0 \\
100.0 \\
99.5 \\
98.9 \\
101.5 \\
99.7 \\
98.5 \\
101.1 \\
98.7 \\
99.7 \\
98.9 \\
99.3 \\
99.3 \\
99.2 \\
99.6 \\
99.6 \\
99.0 \\
99.5 \\
99.9\end{array}$ & $\begin{array}{l}39 \\
40 \\
41 \\
42 \\
43 \\
44 \\
45 \\
46 \\
47 \\
48 \\
49 \\
50 \\
51 \\
52 \\
53 \\
54 \\
55 \\
56 \\
57 \\
58 \\
59 \\
60 \\
61 \\
62 \\
63 \\
64 \\
65 \\
66 \\
67 \\
68 \\
69 \\
70 \\
71 \\
72 \\
73 \\
74 \\
75 \\
76\end{array}$ & $\begin{array}{l}55.4 \\
52.6 \\
55.6 \\
57.3 \\
52.1 \\
62.3 \\
61.6 \\
52.6 \\
55.9 \\
54.3 \\
51.6 \\
55.0 \\
55.1 \\
55.1 \\
54.7 \\
55.2 \\
53.7 \\
56.6 \\
56.2 \\
55.2 \\
54.1 \\
52.8 \\
60.6 \\
50.3 \\
56.7 \\
55.1 \\
53.9 \\
55.9 \\
57.7 \\
55.5 \\
55.5 \\
54.3 \\
56.4 \\
55.1 \\
56.8 \\
57.1 \\
55.7 \\
56.0\end{array}$ & $\begin{array}{r}9.5 \\
10.7 \\
9.6 \\
10.0 \\
10.5 \\
4.8 \\
4.7 \\
10.9 \\
9.3 \\
10.0 \\
11.0 \\
9.8 \\
9.4 \\
9.0 \\
10.5 \\
9.8 \\
10.0 \\
8.2 \\
9.3 \\
9.3 \\
10.4 \\
9.7 \\
5.1 \\
9.4 \\
8.3 \\
9.2 \\
10.3 \\
8.5 \\
8.5 \\
9.0 \\
9.4 \\
8.8 \\
9.0 \\
8.8 \\
8.0 \\
9.2 \\
9.2 \\
8.8\end{array}$ & 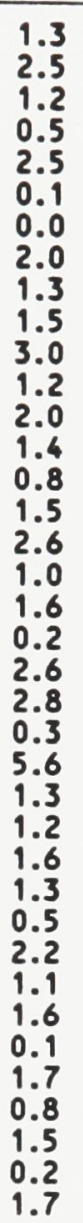 & $\begin{array}{l}33.6 \\
33.6 \\
33.5 \\
34.2 \\
33.5 \\
33.1 \\
33.2 \\
33.9 \\
34.3 \\
33.7 \\
33.8 \\
33.6 \\
33.8 \\
33.6 \\
33.8 \\
33.4 \\
33.8 \\
33.2 \\
33.8 \\
34.0 \\
34.1 \\
33.7 \\
33.3 \\
34.0 \\
33.5 \\
34.0 \\
33.8 \\
33.4 \\
33.8 \\
34.0 \\
33.7 \\
34.1 \\
33.5 \\
33.7 \\
33.4 \\
33.8 \\
34.5 \\
33.8\end{array}$ & $\begin{array}{r}99.8 \\
99.6 \\
99.9 \\
102.0 \\
98.6 \\
100.3 \\
99.5 \\
99.4 \\
100.8 \\
99.5 \\
99.4 \\
99.4 \\
100.3 \\
99.1 \\
99.8 \\
99.9 \\
100.1 \\
99.0 \\
100.9 \\
98.7 \\
101.2 \\
99.0 \\
99.3 \\
99.3 \\
99.8 \\
99.5 \\
99.6 \\
99.1 \\
100.5 \\
100.7 \\
99.7 \\
98.8 \\
99.0 \\
99.3 \\
99.0 \\
101.6 \\
99.6 \\
100.3\end{array}$ \\
\hline
\end{tabular}


APPENDIX 3 (CONTINUED)

COMPOSITION OF SPHALERITE IN FARO ORE

\begin{tabular}{|c|c|c|c|c|c|c|c|c|c|c|c|}
\hline anal. & $2 n$ & Fe & Mn & $\mathbf{S}$ & total & anal. & $2 n$ & $\mathrm{Fe}$ & Mn & $\mathbf{S}$ & total \\
\hline 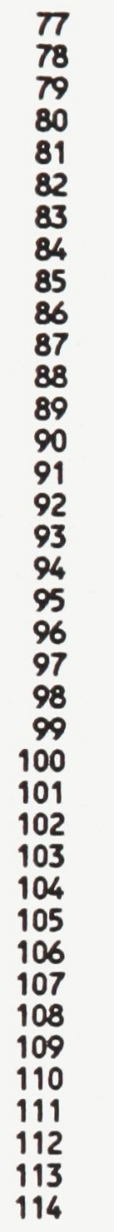 & $\begin{array}{l}\quad 54.8 \\
50.9 \\
52.7 \\
58 .\end{array}$ & $\begin{array}{r}9.5 \\
10.0 \\
9.5 \\
7.5 \\
9.1 \\
10.0 \\
8.5 \\
9.2 \\
8.8 \\
8.6 \\
9.1 \\
9.0 \\
9.3 \\
9.7 \\
8.6 \\
8.8 \\
9.5 \\
8.8 \\
9.4 \\
9.5 \\
8.8 \\
9.5 \\
8.7 \\
8.8 \\
9.5 \\
8.8 \\
9.7 \\
9.5 \\
9.6 \\
11.3 \\
8.8 \\
7.1 \\
10.5 \\
9.6 \\
11.2 \\
10.1 \\
11.1 \\
9.9\end{array}$ & $\begin{array}{l}1.6 \\
4.1 \\
2.8 \\
0.2 \\
2.6 \\
4.9 \\
0.1 \\
0.6 \\
1.8 \\
1.8 \\
2.1 \\
3.2 \\
2.7 \\
2.0 \\
2.2 \\
1.1 \\
1.6 \\
0.4 \\
1.9 \\
2.7 \\
1.6 \\
1.1 \\
0.3 \\
1.2 \\
0.1 \\
1.3 \\
1.9 \\
0.5 \\
1.4 \\
5.0 \\
1.9 \\
0.2 \\
0.4 \\
1.4 \\
3.0 \\
2.7 \\
0.2 \\
1.6\end{array}$ & $\begin{array}{l}33.7 \\
33.7 \\
34.1 \\
33.5 \\
33.9 \\
34.0 \\
33.7 \\
33.7 \\
33.7 \\
33.8 \\
33.9 \\
34.0 \\
34.0 \\
33.6 \\
34.0 \\
33.5 \\
33.7 \\
33.7 \\
33.7 \\
34 \\
34.0 \\
33.9 \\
33.4 \\
33.7 \\
33.7 \\
33.4 \\
33.4 \\
33.5 \\
33.8 \\
34.0 \\
34.0 \\
33.5 \\
33.7 \\
34.3 \\
33.6 \\
33.5 \\
34.9 \\
34.0 \\
34.0 \\
33.4 \\
33.4\end{array}$ & $\begin{array}{r}99.6 \\
98.7 \\
99.1 \\
99.7 \\
99.0 \\
100.0 \\
99.0 \\
98.9 \\
98.8 \\
99.3 \\
99.1 \\
99.4 \\
99.7 \\
100.1 \\
99.1 \\
99.7 \\
99.0 \\
101.3 \\
99.9 \\
101.6 \\
98.6 \\
99.1 \\
99.1 \\
99.3 \\
99.8 \\
99.9 \\
101.5 \\
100.4 \\
99.2 \\
99.6 \\
100.8 \\
99.5 \\
99.3 \\
100.5 \\
99.9 \\
100.5 \\
99.3 \\
99.6\end{array}$ & $\begin{array}{l}115 \\
116 \\
117 \\
118 \\
119 \\
120 \\
121 \\
122 \\
123 \\
124 \\
125 \\
126 \\
127 \\
128 \\
129 \\
130 \\
131 \\
132 \\
133 \\
134 \\
135 \\
136 \\
137 \\
138 \\
139 \\
140 \\
141 \\
142 \\
143 \\
144 \\
145 \\
146 \\
147 \\
148 \\
149 \\
150 \\
151\end{array}$ & 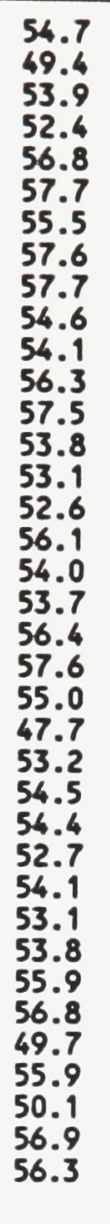 & $\begin{array}{r}10.0 \\
10.9 \\
9.9 \\
10.8 \\
8.5 \\
8.7 \\
9.1 \\
8.4 \\
8.4 \\
8.9 \\
9.7 \\
9.3 \\
8.0 \\
10.8 \\
10.4 \\
10.2 \\
8.6 \\
10.5 \\
10.1 \\
9.9 \\
9.7 \\
10.0\end{array}$ & $\begin{array}{l}1.3 \\
5.0 \\
2.1 \\
2.2 \\
0.7 \\
0.1 \\
2.2 \\
0.5 \\
0.4 \\
1.6 \\
1.6 \\
0.4 \\
0.0 \\
1.4 \\
2.0 \\
2.2 \\
1.5 \\
0.2 \\
1.3 \\
0.0 \\
0.1 \\
0.6 \\
6.0 \\
1.3 \\
1.2 \\
0.1 \\
3.0 \\
0.5 \\
1.2 \\
1.1 \\
0.0 \\
0.4 \\
5.1 \\
0.1 \\
4.2 \\
0.3 \\
0.0\end{array}$ & $\begin{array}{l}33.7 \\
33.8 \\
33 . \\
33 \\
34.3 \\
33.9 \\
33.9 \\
33 .\end{array}$ & $\begin{array}{r}99.7 \\
99.1 \\
99.2 \\
99.7 \\
99.9 \\
100.3 \\
100.4 \\
99.7 \\
100.4 \\
99.6 \\
99.2 \\
99.1 \\
98.7 \\
99.3 \\
99.2 \\
98.9 \\
99.7 \\
98.0 \\
98.5 \\
99.5 \\
100.9 \\
99.0 \\
98.8 \\
98.5 \\
98.3 \\
98.6 \\
98.9 \\
98.7 \\
98.2 \\
98.2 \\
98.1 \\
98.8 \\
99.3 \\
98.9 \\
99.3 \\
98.7 \\
99.0\end{array}$ \\
\hline & & & & & & $\begin{array}{l}\text { RAGE }= \\
\text { MAX }= \\
\text { MIN }= \\
\text { DEV }=\end{array}$ & $\begin{array}{r}55.2 \\
62.3 \\
48.3 \\
2.2\end{array}$ & $\begin{array}{r}9.4 \\
11.3 \\
4.7 \\
1.1\end{array}$ & $\begin{array}{l}1.4 \\
6.1 \\
0.0 \\
1.2\end{array}$ & $\begin{array}{r}33.7 \\
34.5 \\
33.0 \\
0.3\end{array}$ & \\
\hline
\end{tabular}

Each analysis is one spot. Analyses 1 to 54 fron Lead scavenger tails, 55 to 125 from final lead conc, 126 to 151 from final zinc conc.

Accelerating Voltage $20.0 \mathrm{Kv}$, Beam Current $20 \mathrm{~m}$, counting times 100 seconds, standards and $X$-ray emission lines used are sphalerite with $\mathbf{9 . 4 9 \%}$ Fe (ZnK., FeK.,SKe) and MnS (MnKa), ZAF correction applied. 
APPENDIX 4

TRACE ELEMENT CONTENT OF GALENA IN FARO ORE' ${ }^{*}(\mathrm{ppm})$

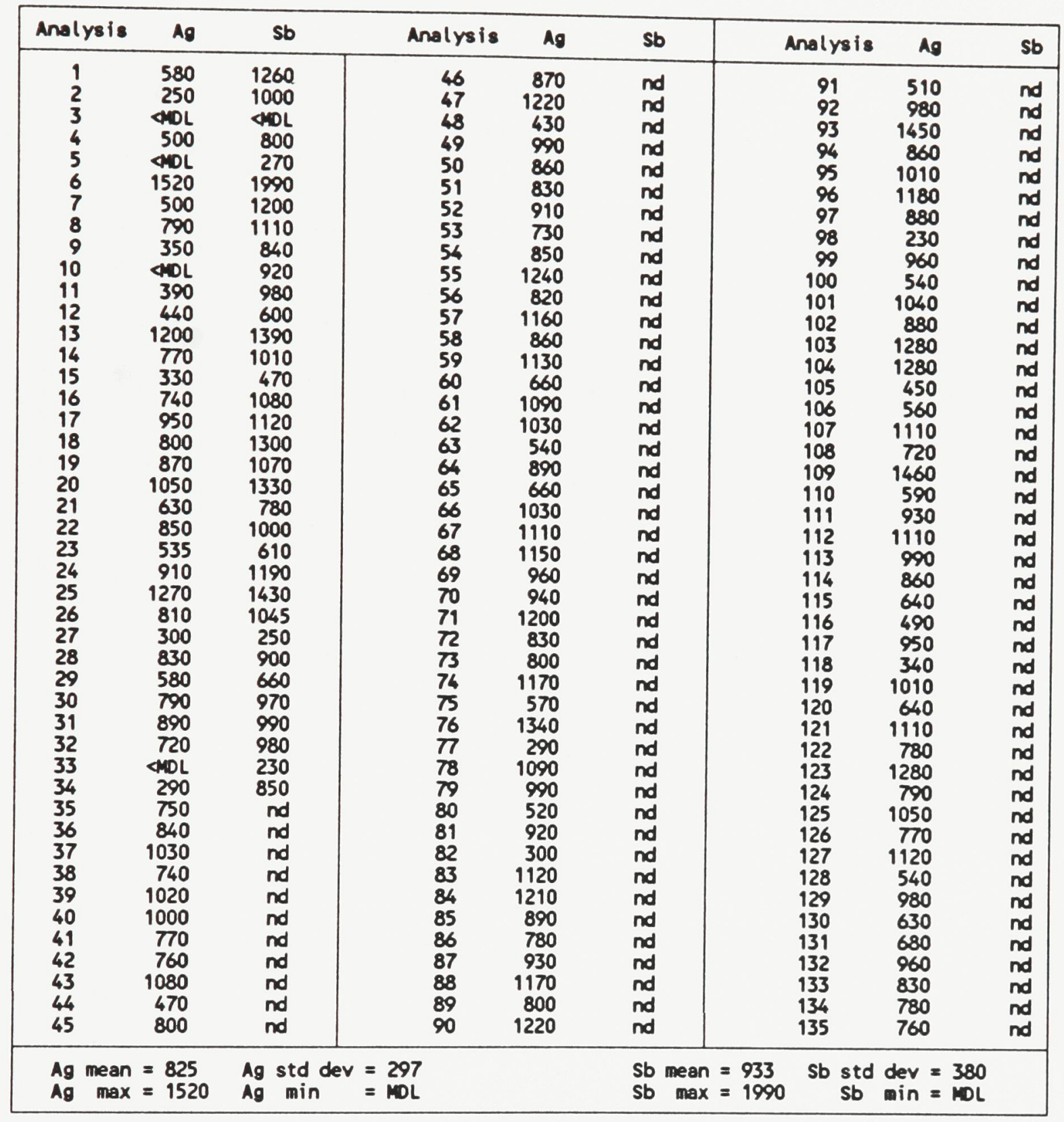

All analyses from final lead conc. As and Bi not detected; nd = not deterwined

Accelerating Voltage $20.0 \mathrm{Kv}$, Beam Current $40 \mathrm{~m}$, counting times 100 seconds, standards and $X$-ray

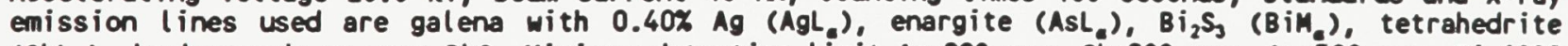
$\left(S b L_{\star}\right)$, backgrounds on pure PbS. Minimum detection limit Ag=290 ppm, Sb=200 ppm, As=500 ppm, Bi=1000 ppm. 


\section{APPENDIX $5^{\circ}$}

COMPOSITIONS OF TETRAHEDRITE IN FARO ORE (WT ₹)

\begin{tabular}{rrrlllllr} 
Anal. Cu & \multicolumn{1}{l}{ Ag } & Fe & Zn & Sb & As & S & Total \\
1 & 23.34 & 19.82 & 5.92 & 1.38 & 26.44 & 0.28 & 22.65 & 99.83 \\
2 & 25.35 & 17.85 & 5.67 & 1.22 & 27.13 & 0.31 & 23.00 & 100.53 \\
3 & 20.78 & 21.74 & 7.18 & 1.66 & 24.28 & 0.25 & 22.26 & 98.15 \\
4 & 22.16 & 22.04 & 4.80 & 2.10 & 26.67 & 0.31 & 22.12 & 100.20 \\
5 & 22.99 & 19.79 & 5.98 & 1.15 & 26.56 & 0.27 & 22.36 & 99.10 \\
6 & 21.60 & 21.93 & 6.14 & 1.16 & 26.59 & 0.27 & 22.15 & 99.84 \\
7 & 16.83 & 29.30 & 6.42 & 0.92 & 25.44 & 0.23 & 21.37 & 100.51 \\
8 & 21.35 & 21.80 & 4.65 & 3.45 & 26.04 & 0.27 & 22.10 & 99.66 \\
9 & 23.97 & 18.77 & 6.14 & 1.29 & 26.95 & 0.34 & 22.75 & 100.21 \\
10 & 23.68 & 18.62 & 6.20 & 1.39 & 26.90 & 0.33 & 22.62 & 99.74 \\
11 & 20.81 & 22.37 & 6.32 & 1.03 & 25.89 & 0.31 & 21.82 & 98.55 \\
12 & 25.89 & 15.40 & 5.28 & 2.58 & 26.87 & 0.28 & 22.54 & 98.84 \\
13 & 23.40 & 19.21 & 3.48 & 4.82 & 26.45 & 0.30 & 22.47 & 100.13 \\
14 & 32.88 & 5.34 & 6.03 & 2.59 & 28.05 & 0.49 & 23.60 & 98.98 \\
15 & 16.04 & 29.62 & 6.72 & 1.63 & 25.73 & 0.28 & 20.71 & 100.73 \\
16 & 23.35 & 19.28 & 6.54 & 1.02 & 26.96 & 0.32 & 22.35 & 99.82 \\
17 & 23.13 & 18.98 & 6.35 & 1.01 & 26.58 & 0.26 & 22.27 & 98.58 \\
18 & 15.74 & 29.71 & 6.75 & 0.80 & 25.35 & 0.26 & 20.60 & 99.21 \\
19 & 18.21 & 25.81 & 6.83 & 0.71 & 25.75 & 0.26 & 21.61 & 99.18 \\
& & & & & & & & \\
AVG & 22.18 & 20.91 & 5.97 & 1.68 & 26.35 & 0.30 & 22.18 & 99.57 \\
MAX & 32.88 & 29.71 & 7.18 & 4.82 & 28.05 & 0.49 & 23.60 & 100.73 \\
MIN & 15.74 & 5.34 & 3.48 & 0.71 & 24.28 & 0.23 & 20.60 & 98.15 \\
STD & 3.82 & 5.42 & 0.86 & 1.01 & 0.80 & 0.05 & 0.71 & 0.72
\end{tabular}

\section{- All analyses from lead first cleaner tails}

Accelerating voltage $20.0 \mathrm{Kv}$, Beam current $15 \mathrm{nA}$, counting times 100 seconds, standards and $\mathrm{x}$-ray emission lines used are tetrahedrite with $3.37 \% \mathrm{Fe}\left(\mathrm{CuK}_{\mathrm{a}}, \mathrm{FeK}_{\mathrm{a}}, \mathrm{SbL}_{\mathrm{a}}, \mathrm{SK}_{\mathrm{a}}\right.$ ), Ag metal $\left(\mathrm{AgL}_{a}\right)$, sphalerite with $4.78 \mathrm{Fe}\left(\mathrm{ZnK}_{a}\right)$ and enargite $\left(\mathrm{AsL}_{\mathrm{a}}\right), \mathrm{ZAF}$ correction applied. 


\section{APPENDIX 6 “* \\ COMPOSITIONS OF CARBONATES IN FARO ORE}

1

$\begin{array}{rr}\text { Feo } & 46.30 \\ \text { Mno } & 1.60 \\ \text { Zno } & 0.32 \\ \text { Mgo } & 3.86 \\ \mathrm{CaO} & 2.84 \\ \mathrm{BaO}^{*} & 0.23 \\ \mathrm{CO}_{2}{ }^{*} & 44.85\end{array}$

$\mathrm{Fe}, \mathrm{Mg}_{12} \mathrm{Ca}_{. \infty} \mathrm{Mn}_{.00} \mathrm{CO}_{3}$

5

FeO

Mno

Zno

Mgo

CaO

$\mathrm{BaO}$

$\mathrm{CO}_{2}{ }^{*}$

$$
\mathrm{Fe}_{90.9 \mathrm{Mn}_{.01}} \mathrm{CO}_{3}
$$

9

FeO

Mno 0.00

Zno 0.00

Mgo 16.51

CaO 23.53

$\mathrm{BaO} \quad 0.00$

$\mathrm{CO}_{2}{ }^{*} 51.61$

$\mathrm{Ca}_{13} \mathrm{Mg}_{{ }_{13}} \mathrm{Fe}_{12} \mathrm{CO}_{3}$
2

54.78

0.35

0.11

0.88

1.69

0.20

41.99

$\mathrm{Fe}_{93} \mathrm{Ca}_{.04} \mathrm{MBg}_{.03} \mathrm{Mn}_{91} \mathrm{CO}$,

6

50.48
1.38
0.30
1.49
2.49
0.36
43.50

$\mathrm{Fe}_{.0} \mathrm{Ca}_{.05} \mathrm{Mg}_{\mathrm{gos}} \mathrm{Mn}_{.08} \mathrm{Zn}_{.01} \mathrm{CO}_{3}$

10

56.42

0.10

0.22

0.65

1.23

0.13

41.25

$\mathrm{Fe}_{93} \mathrm{Cla}_{.03} \mathrm{Mg}_{. .2} \mathrm{CO}_{3}$
3

58.47

0.17

0.11

0.17

0.10

0.03

40.95

$\mathrm{Fe}_{9 .} \mathrm{Mg}_{.1} \mathrm{CO}$,

7

8

55.49

0.05

0.14

0.28

0.88

0.07

43.09

$\mathrm{Fe}_{9} \mathrm{Ca}_{.02} \mathrm{Mg}_{.01} \mathrm{CO}$,

$\mathrm{Fe}_{.0} \mathrm{Ca}_{.05} \mathrm{Mg}_{. .05} \mathrm{CO}_{3}$
59.47

0.10

0.19

0.07

0.03

0.07

40.07

$\mathrm{Fe}, \mathrm{Zn}_{01} \mathrm{CO}_{3}$

- by difference

* All analyses from final zinc tails

Accelerating Voltage $13.0 \mathrm{Kv}$, Beam current $10 \mathrm{nA}$, counting times 60 seconds, standards and X-ray emission lines used are dolomite ( $\mathrm{CaK}_{\mathrm{s}}, \mathrm{MgK}_{\mathrm{s}}$ ), rhodochrosite $\left(\mathrm{MnK}_{\mathrm{a}}\right), \mathrm{Zn}$ ferrite ( $\mathrm{ZnK}_{\mathrm{a}}$, FeK, and barite $\left(\mathrm{BaL}_{\mathbf{a}}\right), \mathrm{ZAF}$ correction applied. 


\section{APPENDIX 7}

FARO AND VANGORDA GRINDING CIRCUITS OPERATING PARAMETERS

\begin{tabular}{|l|c|c|c|c|}
\hline & Rod Mill & $\begin{array}{l}\text { Primary } \\
\text { Ball Mill }\end{array}$ & $\begin{array}{l}\text { Secondary } \\
\text { Ball Mill }\end{array}$ & $\begin{array}{l}\text { Regrind } \\
\text { Mills }\end{array}$ \\
\hline \hline Speed (rpm) & 16.3 & 16.35 & 16.4 & 20.4 \\
\hline $\begin{array}{l}\text { Media Dia. } \\
\text { (cm) }\end{array}$ & 10.1 & 3.8 & 2.5 & 2.5 \\
\hline $\begin{array}{l}\text { Pulp Density } \\
\text { (8solids) }\end{array}$ & 80 & 82 & 82 & 80 \\
\hline $\begin{array}{l}\text { Cyclone Feed } \\
\text { Density } \\
\text { (zsolids) }\end{array}$ & - & 65 & 60 & 60 \\
\hline $\begin{array}{l}\text { Target Grind } \\
\text { (80\% passing) }\end{array}$ & - & - & 75 & 25 \\
\hline $\begin{array}{l}\text { Circulating } \\
\text { Load (8) }\end{array}$ & - & 200 & 200 & 200 \\
\hline Discharge & Grate & Grate & Grate & overflow \\
\hline
\end{tabular}




\author{
APPENDIX 8 \\ FARO PLANT SOLID FLOWRATES (TPH)
}

LEAD CIRCUIT

stream

LEAD ROUGHER FEED

LEAD ROUGHER CONCENTRATE

LEAD ROUGHER TAIL

LEAD SCAVENGER CONCENTRATE

LEAD SCAVENGER TAIL

LEAD CYCLONE UNDERFLOW

LEAD REGRIND DISCHARGE

LEAD CYCLONE OVERFLOW

LEAD FIRST CLEANER CONCENTRATE

LEAD FIRST CLEANER TAIL

LEAD SECOND CLEANER CONCENTRATE

LEAD SECOND CLEANER TAIL

LEAD THIRD CLEANER TAIL

LEAD THIRD CLEANER CONCENTRATE
Measured

550.60

$-$

$-$

$-$

$-$

$-$

$-$

-

-

-

-

-

$-$
Balanced

550.60

124.08

570.55

51.97

518.58

228.06

228.06

124.08

136.47

92.06

71.43

104.45

39.41

32.02

ZINC CIRCUIT

Stream

LEAD SCAVENGER TAIL

ZINC SCAVENGER CONCENTRATE

ZINC ROUGHER FEED

ZINC ROUGHER CONCENTRATE

ZINC ROUGHER TAIL

ZINC SCAVENGER TAIL

ZINC REGRIND DISCHARGE

ZINC CYCLONE UNDERFLOW

ZINC CYCLONE OVERFLOW

ZINC SECOND CLEANER TAIL

ZINC FIRST CLEANER CONCENTRATE

ZINC FIRST CLEANER TAIL

ZINC SECOND CLEANER CONCENTRATE

ZINC THIRD CLEANER TAIL

ZINC THIRD CLEANER CONCENTRATE

ZINC FINAL TAIL
Measured

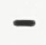

$-$

-

$-$

$-$

$-$

$\overline{-}$

-

-

-

-

-

-

-

-
Balanced

518.58

22.42

541.00

72.87

468.13

445.71

89.46

89.46

72.87

86.13

131.25

27.76

92.82

47.71

45.12

473.46 


\section{APPENDIX 9}

FARO STREAM PARTICLE SIZE DISTRIBUTIONS (WTX)

LEAD CIRCUIT

Stream

LEAD ROUGHER FEED

LEAD ROUGHER CONC.

LEAD ROUGHER TAIL

LEAD SCAVENGER CONC.

LEAD SCAVENGER TAIL

LEAD CYCLONE UNDERFLO

LEAD REGRIND DISCHAREE

LEAD CYCLONE OVERFLON

LEAD FIRST CLEANER CONC.

LEAD FIRST CLEANER TAIL

LEAD SECOND CLEANER CONC.

LEAD SECOND CLEANER TAIL

LEAD THIRD CLEANER TAIL

LEAD THIRD CLENMER CONC.
$+75$

Measured Balanced

18.86

4.85

18.32

8.52

16.95

5.92

5.53

2.02

1.6

3.89

1.97

3.89

1.97

1.96

\subsection{0}

4.71

17.47

8.54

18.37

6.37

5.15

2.47

2.00

2.72

1.90

2.08

2.02

1.75
$-75 \mu M+38 \mu$

Measured Balanced

$26.40 \quad 26.35$

$26.56 \quad 27.32$

$25.40 \quad 25.51$

$25.36 \quad 25.36$

$25.51 \quad 25.52$

$43.25 \quad 40.84$

$34.07 \quad 35.97$

$17.11 \quad 18.37$

$25.06 \quad 26.33$

$25.29 \quad 23.00$

$11.19 \quad 13.51$

$34.03 \quad 32.85$

26.9620 .37

$5.36 \quad 5.06$
$-38 \mu$

Measured Balanced

54.74

67.97

$66.12 \quad 66.10$

$57.54 \quad 56.11$

$50.83 \quad 52.80$

$60.40 \quad 58.88$

$80.87 \quad 79.16$

$73.34 \quad 71.66$

$70.82 \quad 74.28$

$86.84 \quad 84.60$

$62.08 \quad 65.07$

$71.07 \quad 77.62$

$92.68 \quad 93.19$

ZINC CIRCUIT

$+75 \quad$

Stream

LEAD SCAVENGER TAIL

ZINC SCAVENGER CONC.

ZINC ROUGHER FEED

ZINC ROUGHER CONC.

ZINC ROUGHER TAIL

ZINC SCAVENGER TAIL

ZINC REGRIND DISCHARGE

ZINC CYCLONE UNDERFLON

ZINC CYCLONE OVERFLOW

ZINC SECOND CLEANER TAIL

ZINC FIRST CLEANER CONC.

ZINC FIRST CLEANER TAIL

ZINC SECOND CLEANER CONC.

ZINC THIRD CLEANER TAIL

ZINC THIRD CLEANER CONC.

FINAL TAIL

\section{Measured Balanced}

$16.95 \quad 17.26$

$20.23 \quad 20.22$

$17.09 \quad 17.38$

$10.79 \quad 9.55$

$18.60 \quad 18.60$

$19.38 \quad 18.52$

$5.33 \quad 4.96$

$9.73 \quad 10.91$

$5.07 \quad 2.24$

$10.74 \quad 12.82$

$\begin{array}{ll}13.53 \quad 8.57 \\ 4.31 & 5.17\end{array}$

$4.31 \quad 5.17$

$3.81 \quad 4.23$

9.037 .81

$.43 \quad .44$

17.51

17.73
$-75 \quad M+38 \quad M$

Measured Balanced

25.51

35.08

25.27

29.62

26.08

25.82

31.81

38.38

22.18

47.12

45.13

19.45

35.70

43.52

12.51

25.04
25.74

35.05

26.12

28.59

25.74

25.27

30.39

39.73

17.12

52.00

39.15

21.19

31.06

46.61

14.62

25.03
$.38 M$

Measured Balanced

$\begin{array}{ll}57.54 & 57.01 \\ 44.69 & 44.73 \\ 57.63 & 56.49 \\ 59.59 & 61.86 \\ 55.32 & 55.66 \\ 54.80 & 56.21 \\ 62.86 & 64.65 \\ 51.89 & 49.36 \\ 72.75 & 80.63 \\ 42.14 & 35.17 \\ 41.35 & 52.29 \\ 76.24 & 73.64 \\ 60.48 & 64.70 \\ 47.45 & 45.58 \\ 87.07 & 84.95 \\ 57.46 & 57.25\end{array}$

$57.54 \quad 57.01$

44.73

$59.59 \quad 61.86$

$55.32 \quad 55.66$

$54.80 \quad 56.21$

$51.89 \quad 49.36$

$72.75 \quad 80.63$

$42.14 \quad 35.17$

$41.35 \quad 52.29$

$60.48 \quad 64.70$

45.58

$57.46 \quad 57.25$ 


\section{APPENDIX 10}

FARO CONCENTRATOR MEASURED AND BALANCED STREAM ASSAYS AND DISTRIBUTION

(x)

LEAD CIRCUIT

LEND (WTX)

ZINC (UTX)

SILVER (PPM)

\begin{tabular}{lrrr} 
Stream & Meas. & Bal. & \multicolumn{1}{c}{ Dist. } \\
FEED & & & \\
RO. CONC. & 19.34 & 4.33 & 100.00 \\
RO. TAIL & 1.43 & 20.33 & 105.76 \\
SCAV. CONC. & 6.44 & 6.68 & 31.10 \\
SCAV. TAIL & .73 & .76 & 14.55 \\
CYC. U/FLO & 26.90 & 26.43 & 252.54 \\
REG. DISC. & 26.00 & 26.43 & 252.73 \\
CYC. O/FLOU & 20.40 & 20.33 & 105.76 \\
IST CL. CONC. & 25.00 & 24.77 & 141.73 \\
IST CL. TAIL & 5.80 & 5.78 & 22.31 \\
2ND CL. CONC. & 42.20 & 41.67 & 124.77 \\
2ND CL. TAIL & 13.30 & 13.31 & 58.27 \\
3RD CL. TAIL & 24.90 & 25.00 & 41.31 \\
3RD CL. CONC. & 62.23 & 62.18 & 83.46
\end{tabular}

\begin{tabular}{rrr} 
Meas. & \multicolumn{1}{c}{ Bal. } & Dist. \\
5.17 & 5.30 & 100.00 \\
12.14 & 11.94 & 50.77 \\
5.96 & 5.87 & 114.79 \\
12.70 & 12.74 & 22.69 \\
5.24 & 5.18 & 92.10 \\
9.36 & 9.45 & 73.91 \\
9.55 & 9.45 & 73.91 \\
12.20 & 11.94 & 50.77 \\
15.80 & 15.30 & 71.56 \\
12.70 & 13.58 & 42.86 \\
13.20 & 12.41 & 30.39 \\
17.70 & 17.78 & 63.66 \\
16.00 & 16.64 & 22.48 \\
7.14 & 7.20 & 7.90
\end{tabular}

Meas. Bal. Dist.

$\begin{array}{lll}65 & 65 \quad 100.00\end{array}$

$235 \quad 243 \quad 84.95$

$39 \quad 40 \quad 64.95$

$\begin{array}{lll}125 & 126 & 18.07\end{array}$

$\begin{array}{lll}33 & 32 \quad 46.88\end{array}$

$\begin{array}{lll}288 & 288 & 184.74\end{array}$

$288 \quad 288 \quad 184.74$

$242 \quad 243 \quad 84.95$

$\begin{array}{lll}281 & 267 & 102.39\end{array}$

$\begin{array}{lll}125 & 123 \quad 31.84\end{array}$

$\begin{array}{lll}426 & 417 & 83.92\end{array}$

$\begin{array}{lll}164 & 168 & 49.27\end{array}$

$276 \quad 278 \quad 30.81$

$\begin{array}{lll}582 & 590 & 53.12\end{array}$

ZINC CIRCUIT

LEAD (WTX)

ZINC (UTX)

SILVER (PPH)

$\begin{array}{lrrr}\text { Stream } & \text { Meas. } & \text { Bal. } & \text { Dist. } \\ \text { PB SC. TAIL } & .73 & .73 & 100.00 \\ \text { SCAV. CONC. } & 2.93 & 2.87 & 16.93 \\ \text { RO. FEED } & .75 & .82 & 116.93 \\ \text { RO. CONC. } & 2.08 & 1.85 & 35.49 \\ \text { RO. TAIL } & .64 & .66 & 81.44 \\ \text { SCAV. TAIL } & .54 & .55 & 64.51 \\ \text { REG. DISCH. } & 2.13 & 2.17 & 51.11 \\ \text { CYC. U/FLON } & 2.21 & 2.17 & 51.11 \\ \text { CYC. O/FLON } & 1.88 & 1.85 & 35.49 \\ \text { 2ND CL. TAIL } & 2.05 & 2.06 & 46.68 \\ \text { 1ST CL. CONC. } & 3.42 & 1.96 & 67.79 \\ \text { 1ST CL. TAIL } & 1.85 & 1.97 & 14.37 \\ \text { 2ND CL. CONC. } & 2.45 & 2.45 & 59.86 \\ \text { 3RD CL. TAIL } & 3.08 & 3.08 & 38.74 \\ \text { 3RD CL. CONC. } & 1.73 & 1.78 & 21.12 \\ \text { FINAL TAIL } & .74 & .63 & 78.88\end{array}$

Meas.

Bal. Dist.

5.24

16.90

5.66

39.10

1.42

.48

38.50

38.50

38.70

33.30

40.00

7.22

46.50

40.70

50.93

1.22

$\begin{array}{rr}5.37 & 100.00 \\ 17.41 & 14.01 \\ 5.87 & 114.01 \\ 35.01 & 91.60 \\ 1.33 & 22.41 \\ .53 & 8.40 \\ 38.50 & 123.65 \\ 38.50 & 123.65 \\ 35.01 & 91.60 \\ 33.30 & 102.98 \\ 39.57 & 186.48 \\ 7.95 & 7.92 \\ 46.03 & 153.39 \\ 40.89 & 70.03 \\ 51.46 & 83.36 \\ .96 & 16.33\end{array}$

Meas. Bal. Dist.

$\begin{array}{lll}33 & 33 & 100.00\end{array}$

$\begin{array}{rrr}89 & 88 & 11.55 \\ 32 & 35 & 111.55\end{array}$

29.69

81.86

70.31

35.59

35.59

29.69

44.29

63.28

10.70

40.97

21.98

18.99 


\section{APPENDIX 10 (CONTINUED)}

FARO CONCENTRATOR MEASURED AND BALANCED STREAM ASSAYS NMD DISTRIBUTION (X)

\begin{tabular}{lccc} 
& \multicolumn{3}{c}{ ANTIMONY (PPM) } \\
Stream & Meas. & Bal. & Dist. \\
& & & \\
FEED & 110 & 119 & 100.00 \\
RO. CONC. & 390 & 402 & 75.95 \\
RO. TAIL & 90 & 83 & 72.33 \\
SCAV. CONC. & 210 & 213 & 16.89 \\
SCAV. TAIL & 70 & 70 & 55.44 \\
CYC. U/FLON & 480 & 490 & 170.05 \\
REG. DISC. & 500 & 490 & 170.05 \\
CYC. O/FLON & 390 & 402 & 75.95 \\
1ST CL. CONC. & 430 & 423 & 87.86 \\
1ST CL. TAIL & 230 & 224 & 31.39 \\
2ND CL. CONC. & 670 & 644 & 70.11 \\
2ND CL. TAIL & 270 & 272 & 43.30 \\
3RD CL. TAIL & 420 & 426 & 25.54 \\
3RD CL. CONC. & 960 & 914 & 44.56
\end{tabular}

LEAD CIRCUIT

\begin{tabular}{rrr}
\multicolumn{3}{c}{ COPPER (WTX) } \\
Meas. & Bal. & Dist. \\
.17 & .17 & 100.00 \\
1.27 & 1.28 & 167.32 \\
.43 & .45 & 271.70 \\
3.55 & 3.41 & 186.89 \\
.16 & .16 & 84.81 \\
.51 & .52 & 124.85 \\
.53 & .52 & 124.85 \\
1.27 & 1.28 & 167.32 \\
.84 & .80 & 114.97 \\
1.61 & 1.57 & 152.13 \\
.68 & .66 & 49.83 \\
.90 & .91 & 99.78 \\
.82 & .83 & 34.64 \\
.45 & .45 & 15.19
\end{tabular}

COLD (PPH)

ZINC CIRCUIT

ANT IMONY (PPM)

COPPER (WT\%)

COLD (PPN)

$\begin{array}{lrrrrrrrrr}\text { Stream } & \text { Meas. } & \text { Bal. } & \text { Dist. } & \text { Meas. } & \text { Bal. } & \text { Dist. } & \text { Meas. } & \text { Bal. } & \text { Dist. } \\ \text { PB SC. TAIL } & 70 & 65 & 100.00 & .16 & .17 & 100.00 & .19 & .22 & 100.00 \\ \text { SCAV. CONC. } & 140 & 139 & 9.25 & 1.13 & 1.11 & 28.23 & .10 & .10 & 2.02 \\ \text { RO. FEED } & 60 & 68 & 109.25 & .19 & .21 & 128.23 & .25 & .21 & 102.02 \\ \text { RO. CONC. } & 80 & 80 & 17.35 & .74 & .67 & 55.30 & .63 & .24 & 15.61 \\ \text { RO. TAIL } & 70 & 66 & 91.90 & .14 & .14 & 72.93 & .38 & .21 & 86.41 \\ \text { SCAV. TAIL } & 60 & 62 & 82.65 & .08 & .09 & 44.70 & .31 & .21 & 84.39 \\ \text { REG. DISCH. } & 80 & 80 & 21.26 & .70 & .70 & 71.51 & .38 & .45 & 35.70 \\ \text { CYC. U/FLO } & 80 & 80 & 21.26 & .71 & .70 & 71.51 & .63 & .45 & 35.70 \\ \text { CYC. O/FLOU } & 70 & 80 & 17.35 & .71 & .67 & 55.30 & .31 & .24 & 15.61 \\ \text { 2ND CL. TAIL } & 110 & 121 & 31.04 & .87 & .87 & 84.95 & .48 & .47 & 36.53 \\ \text { IST CL. CONC. } & 120 & 100 & 38.79 & .84 & .86 & 127.74 & .38 & .39 & 45.14 \\ \text { IST CL. TAIL } & 130 & 116 & 9.60 & .37 & .40 & 12.51 & .25 & .28 & 7.00 \\ \text { 2ND CL. CONC. } & 80 & 76 & 20.90 & .93 & .87 & 91.83 & .10 & .14 & 11.62 \\ \text { 3RD CL. TAIL } & 90 & 93 & 13.14 & .88 & .91 & 49.04 & .40 & .07 & 3.01 \\ \text { 3RD CL. CONC. } & 60 & 58 & 7.76 & .80 & .84 & 42.79 & .29 & .21 & 8.61 \\ \text { FINAL TAIL } & 70 & 66 & 92.24 & .16 & .11 & 57.21 & .16 & .22 & 91.39\end{array}$




\section{APPENDIX 11}

BALANCED MINERAL QUNTITIES IN FARO CONCENTRATOR (WTX)

LEAD FLOTATION CIRCUIT

$\begin{array}{rrrrr}\text { Sphalerite } & \text { Galeno } & \text { Quartz } & \text { Muscovite } & \text { Pyrite- } \\ 9.60 & 5.01 & 11.38 & 4.06 & 39.42 \\ 21.62 & 23.53 & 2.08 & .74 & 36.36 \\ 10.63 & 1.50 & 11.35 & 4.01 & 41.52 \\ 23.08 & 7.72 & 4.62 & 1.77 & 40.70 \\ 9.38 & .88 & 12.02 & 4.24 & 41.60 \\ 17.12 & 30.58 & .49 & .20 & 41.41 \\ 17.12 & 30.58 & .49 & .20 & 41.41 \\ 21.62 & 23.53 & 2.08 & .74 & 36.36 \\ 27.72 & 28.65 & .94 & .51 & 26.96 \\ 24.61 & 6.69 & 2.49 & .61 & 47.59 \\ 22.48 & 48.20 & 1.14 & 1.10 & 14.70 \\ 32.21 & 15.40 & .94 & .32 & 33.97 \\ 30.14 & 28.93 & 1.32 & 1.06 & 23.31 \\ 13.04 & 71.91 & .93 & 1.14 & 4.09\end{array}$

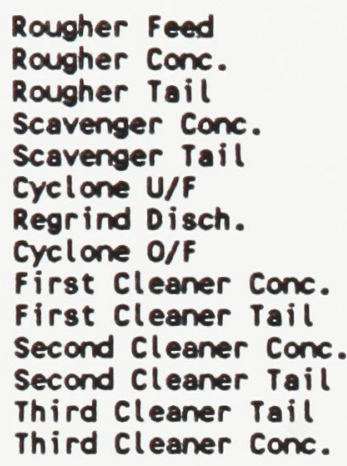

.33
.80
.79
5.30
.34
.50
.50
.80
.51
1.03
.36
.64
.55
.12

Barite- Kaolinite Pyrrhotite

9.96
1.82
9.63
1.53
10.44
1.80
1.80
1.82
1.67
1.73
2.10
1.55
2.12
2.07

.01
.00
.03
.07
.00
.01
.01
.02
.02
.03
.02
.02
.01
.02

1.02

.89

1.10

1.45

1.07

.34

.34

.89

.88

1.13

.76

1.09

1.21

.20

\section{siderite-}

19.24

12.15

19.43

13.76

20.02

7.55

7.55

12.12

12.13

14.10

9.16

13.86

11.33

6.48

- includes a small amount of ankerite

- includes a small amount of magnetite and some marcasite. marcasite/pyrite $=1 / 4$

- includes a small amount of arsenopyrite

- includes small amounts of chlorite, celsian, biotite, rhodochrosite, rutile and apatite 


\title{
APPENDIX 11 (CONTINOED)
}

\author{
BALANCED MINERAL QUANTITIES IN FARO CONCENTRATOR
}

ZIMC FLOTATION CIRCUIT

\begin{tabular}{|c|c|c|c|c|c|}
\hline Stream & Sphalerite & Galena & Quartz & Siderite & Pyrite \\
\hline \multirow[t]{2}{*}{$\begin{array}{l}\text { Lead Scavenger Tail } \\
\text { Scavenger Conc } \\
\text { Rougher Feed } \\
\text { Rougher Conc. } \\
\text { Rougher Tail } \\
\text { Scavenger Tail } \\
\text { Regrind Disch. } \\
\text { Cyclone Underflow } \\
\text { Cyclone Overflow } \\
\text { Second Cleaner Tail } \\
\text { First Cleaner Conc. } \\
\text { First Cleaner Tail } \\
\text { Second Cleaner Conc. } \\
\text { Third Cleaner Tail } \\
\text { Final Conc. } \\
\text { Final Tail }\end{array}$} & $\begin{array}{l}9.72 \\
31.47 \\
10.62 \\
63.34 \\
2.42 \\
.96 \\
69.75 \\
69.75 \\
63.34 \\
60.32 \\
71.71 \\
14.39 \\
83.48 \\
74.04 \\
93.46 \\
1.74\end{array}$ & $\begin{array}{l}.85 \\
3.32 \\
.95 \\
2.14 \\
.76 \\
.63 \\
2.51 \\
2.51 \\
2.14 \\
2.38 \\
2.27 \\
2.28 \\
2.83 \\
3.56 \\
2.06 \\
.73\end{array}$ & $\begin{array}{r}16.21 \\
6.32 \\
15.80 \\
2.85 \\
17.81 \\
18.39 \\
1.69 \\
1.69 \\
2.85 \\
2.06 \\
1.45 \\
7.03 \\
.67 \\
1.03 \\
.29 \\
17.72\end{array}$ & $\begin{array}{l}21.16 \\
18.20 \\
21.04 \\
12.50 \\
22.37 \\
22.58 \\
8.39 \\
8.39 \\
12.50 \\
14.51 \\
10.30 \\
29.14 \\
5.51 \\
8.58 \\
2.23 \\
22.97\end{array}$ & $\begin{array}{l}40.03 \\
32.85 \\
39.73 \\
15.71 \\
43.47 \\
44.01 \\
14.41 \\
14.41 \\
15.71 \\
16.70 \\
11.24 \\
39.92 \\
5.02 \\
9.01 \\
.81 \\
43.77\end{array}$ \\
\hline & Chal copyrite & Barite- & Pyrrhotite & & \\
\hline $\begin{array}{l}\text { Lead Scavenger Tail } \\
\text { Scavenger Conc } \\
\text { Rougher Feed } \\
\text { Rougher Conc. } \\
\text { Rougher Tail } \\
\text { Scavenger Tail } \\
\text { Regrind Disch. } \\
\text { Cyclone Underflow } \\
\text { Cyclone Overflow } \\
\text { Second Cleaner Tail } \\
\text { First Cleaner Conc. } \\
\text { First Cleaner Tail } \\
\text { Second Cleaner Conc. } \\
\text { Third Cleaner Tail } \\
\text { Final Conc. } \\
\text { Final Tail }\end{array}$ & $\begin{array}{r}.20 \\
1.69 \\
.26 \\
.63 \\
.21 \\
.13 \\
1.02 \\
1.02 \\
.63 \\
1.06 \\
.92 \\
.59 \\
1.11 \\
1.54 \\
.65 \\
.16\end{array}$ & $\begin{array}{r}10.35 \\
3.74 \\
10.08 \\
1.86 \\
11.36 \\
11.74 \\
1.89 \\
1.89 \\
1.86 \\
1.57 \\
1.12 \\
4.43 \\
.79 \\
1.27 \\
11.28 \\
11.31\end{array}$ & $\begin{array}{r}1.48 \\
2.40 \\
1.52 \\
.98 \\
1.60 \\
1.56 \\
.34 \\
.34 \\
.98 \\
1.41 \\
1.01 \\
2.20 \\
.60 \\
.94 \\
.24 \\
1.60\end{array}$ & & \\
\hline $\begin{array}{l}\text { - includes small am } \\
\text { - celsian, rhodochr } \\
\text { includes a small a } \\
\text { marcasite/pyrite } \\
\text { - includes a small an }\end{array}$ & $\begin{array}{l}\text { its of musco } \\
i \text { te, rutile } \\
\text { int of magne } \\
1 / 4 \\
\text { it of arsen }\end{array}$ & and & dolomi & chlori & \\
\hline
\end{tabular}




\section{APPENDIX 12}

MINERAL ASSOCIATIONS OF SPHALERITE ATIONS OF SPHALERITE AND GALE CONCENTRATOR PRODUCTS BY SIEVE FRACTIONS

(\% PERIMETER)

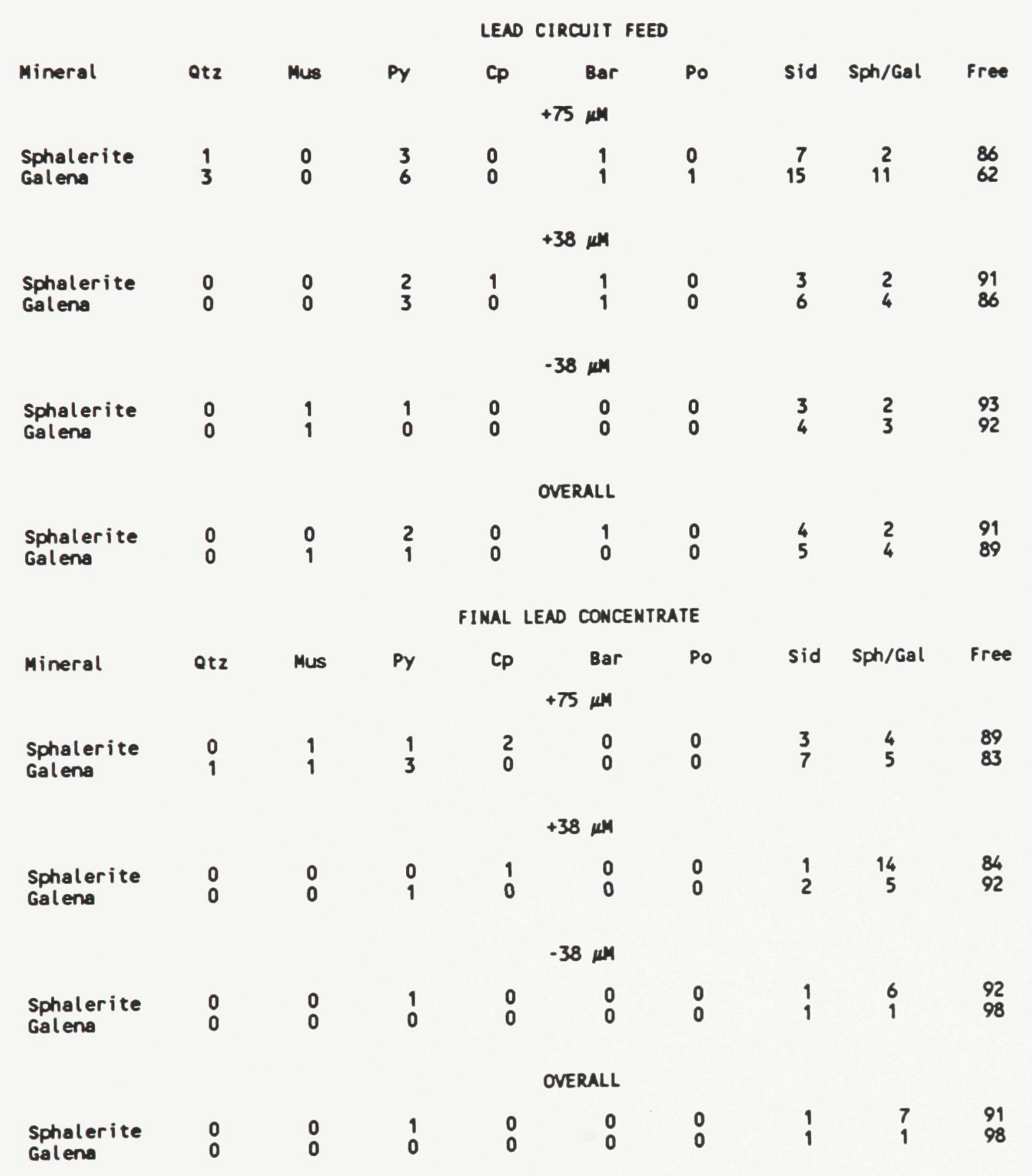




\section{APPENDIX 12 (CONTINUED)}

FIMAL ZINC CONCENTRATE

\begin{tabular}{|c|c|c|c|c|c|c|c|c|c|}
\hline Mineral & Otz & Mus & Py & $C p$ & $\begin{array}{l}\text { Bar } \\
\text { MM }\end{array}$ & Po & sid & Sph/Gal & Free \\
\hline $\begin{array}{l}\text { Sphalerite } \\
\text { Galend }\end{array}$ & $\begin{array}{l}0 \\
0\end{array}$ & $\begin{array}{l}0 \\
0\end{array}$ & $\begin{array}{l}0 \\
2\end{array}$ & $\begin{array}{l}0 \\
1\end{array}$ & $\begin{array}{l}0 \\
0\end{array}$ & $\begin{array}{l}0 \\
0\end{array}$ & $\begin{array}{l}1 \\
6\end{array}$ & $\begin{array}{r}1 \\
23\end{array}$ & $\begin{array}{l}98 \\
68\end{array}$ \\
\hline $\begin{array}{l}\text { Sphalerite } \\
\text { Galene }\end{array}$ & $\begin{array}{l}0 \\
0\end{array}$ & $\begin{array}{l}0 \\
0\end{array}$ & $\begin{array}{l}1 \\
3\end{array}$ & $\begin{array}{l}0 \\
3\end{array}$ & $\begin{array}{l}0 \\
1 \\
\mu M\end{array}$ & $\begin{array}{l}0 \\
0\end{array}$ & $\begin{array}{l}2 \\
3\end{array}$ & $\begin{array}{r}1 \\
23\end{array}$ & $\begin{array}{l}96 \\
67\end{array}$ \\
\hline $\begin{array}{l}\text { Sphalerite } \\
\text { Galena }\end{array}$ & $\begin{array}{l}0 \\
1\end{array}$ & $\begin{array}{l}0 \\
0\end{array}$ & $\begin{array}{l}0 \\
1\end{array}$ & $\begin{array}{l}0 \\
0\end{array}$ & $\begin{array}{r}0 \\
0 \\
\text { ALL }\end{array}$ & $\begin{array}{l}0 \\
0\end{array}$ & $\begin{array}{l}1 \\
0\end{array}$ & $\begin{array}{r}0 \\
11\end{array}$ & $\begin{array}{l}99 \\
87\end{array}$ \\
\hline $\begin{array}{l}\text { Sphalerite } \\
\text { Galena }\end{array}$ & $\begin{array}{l}0 \\
1\end{array}$ & $\begin{array}{l}0 \\
0\end{array}$ & $\begin{array}{l}0 \\
1\end{array}$ & $\begin{array}{l}0 \\
0\end{array}$ & $\begin{array}{l}0 \\
0\end{array}$ & $\begin{array}{l}0 \\
0\end{array}$ & $\begin{array}{l}1 \\
1\end{array}$ & $\begin{array}{r}0 \\
13\end{array}$ & $\begin{array}{l}99 \\
84\end{array}$ \\
\hline
\end{tabular}

FIMAL TAILINGS

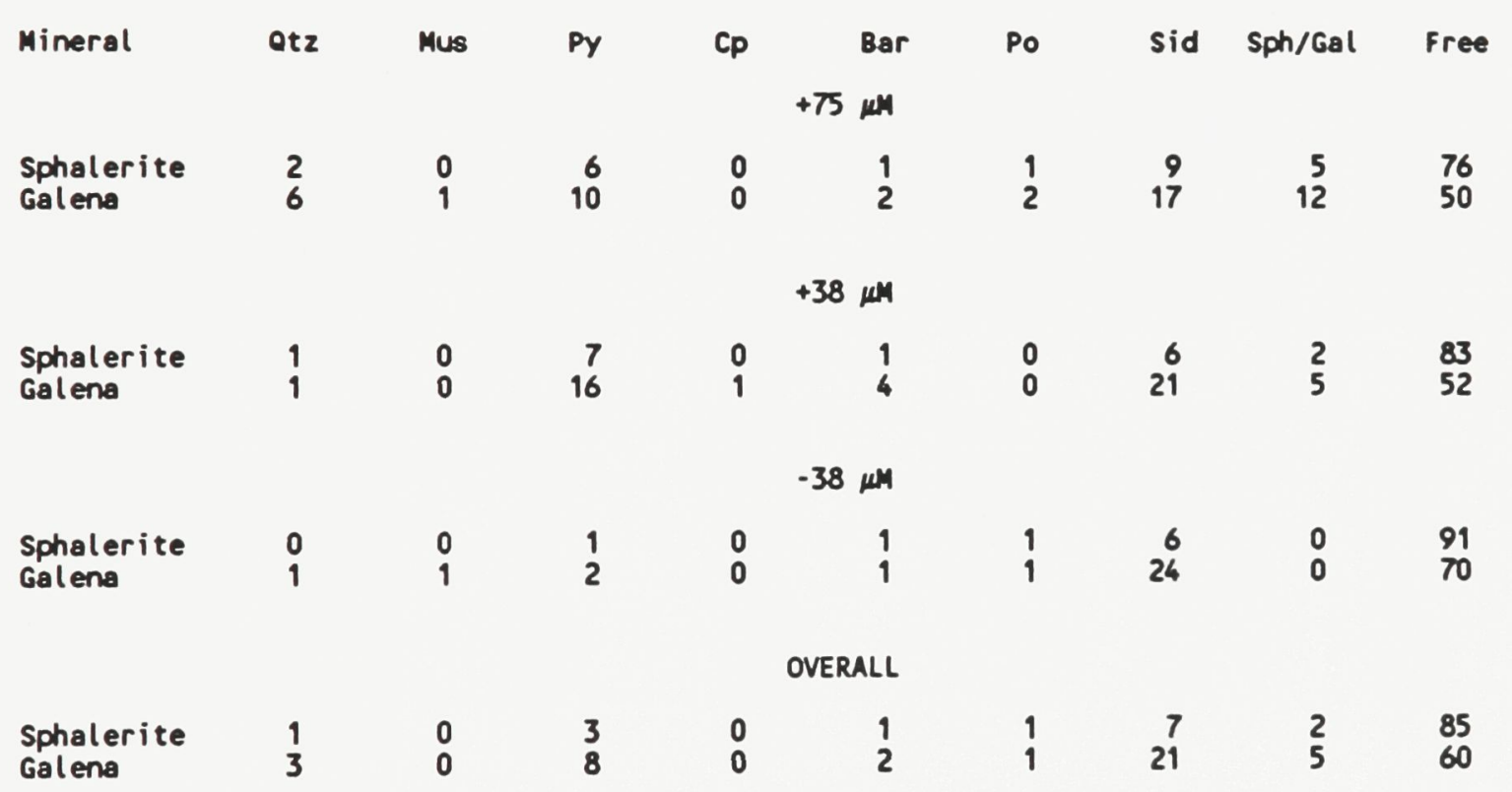




\section{APPENDIX 13}

\begin{tabular}{|c|c|c|c|}
\hline$\underline{\mathrm{DDH}}$ & $\frac{\text { DEPTH }}{\text { (ft.) }}$ & ORETYPE & SECTION \\
\hline $90 \mathrm{~V}-120$ & 98.0 & $4 A$ & $3 E$ \\
\hline $90 \mathrm{~V}-120$ & 111.0 & $4 \mathrm{H}$ & $3 E$ \\
\hline $90 \mathrm{~V}-120$ & 204.0 & $4 G$ & $3 E$ \\
\hline $90 \mathrm{~V}-120$ & 218.0 & $4 E$ & $3 \mathrm{E}$ \\
\hline $90 \mathrm{~V}-120$ & 236.0 & $4 E$ & $3 E$ \\
\hline $90 v-26$ & 113.0 & $4 \mathrm{G}$ & $11 \mathrm{E}$ \\
\hline $90 \mathrm{~V}-26$ & 143.0 & $4 A$ & $11 \mathrm{E}$ \\
\hline $90 V-48$ & 177.5 & $4 E$ & $12 \mathrm{E}$ \\
\hline $90 \mathrm{~V}-72$ & 50.0 & $4 \mathrm{G}$ & $17 \mathrm{E}$ \\
\hline $90 V-04$ & 56.5 & $4 G$ & $21 E$ \\
\hline
\end{tabular}

POLISHED SECTIONS OF VANGORDA DRILLCORE

\begin{tabular}{|c|c|c|c|c|c|c|c|}
\hline$\underline{\mathrm{DDH}}$ & $\frac{\text { DEPTH }}{(\mathrm{ft} .)}$ & ORETYPE & SECTION & $\underline{\mathrm{DDH}}$ & $\frac{\text { DEPTH }}{(\mathrm{ft} .)}$ & ORETYPE & SECTION \\
\hline $87 V-27$ & 101.5 & $4 A$ & 00 & $87 V-11$ & 85.0 & $4 A$ & $02 \mathrm{E}$ \\
\hline $87 V-27$ & 109.5 & 4A & 00 & $87 \mathrm{~V}-11$ & 140.5 & 4D & $02 \mathrm{E}$ \\
\hline $87 v-27$ & 211.5 & $4 \mathrm{~A}$ & 00 & $87 \mathrm{~V}-11$ & 164.5 & 4G & $02 \mathrm{E}$ \\
\hline $87 v-27$ & 231.7 & 4G & 00 & $87 \mathrm{~V}-11$ & 195.0 & 4G & $02 \mathrm{E}$ \\
\hline $87 V-27$ & 254.4 & $4 \mathrm{E}$ & 00 & $87 \mathrm{~V}-11$ & 257.5 & 4D & $02 \mathrm{E}$ \\
\hline $87 V-27$ & 263.9 & 4G & 00 & $87 \mathrm{~V}-11$ & 277.8 & $4 C$ & $02 \mathrm{E}$ \\
\hline $87 V-27$ & 277.8 & $4 \mathrm{E}$ & 00 & & & & \\
\hline $87 V-09$ & 79.5 & $4 G$ & $03 E$ & $87 \mathrm{~V}-10$ & 82.5 & $4 \mathrm{~A}$ & 03E \\
\hline $87 V-09$ & 99.0 & $4 \mathrm{~A}$ & $03 E$ & $87 V-10$ & 170.0 & $4 \mathrm{E}$ & $03 \mathrm{E}$ \\
\hline $87 V-09$ & 134.5 & 4G & $03 \mathrm{E}$ & $87 \mathrm{~V}-10$ & 189.9 & $4 \mathrm{E}$ & 03E \\
\hline $87 V-09$ & 148.9 & 4G & $03 E$ & $87 V-10$ & 193.3 & $4 G$ & $03 E$ \\
\hline $87 V-09$ & 194.0 & $4 \mathrm{E}$ & $03 E$ & $87 \mathrm{~V}-10$ & 221.5 & $4 \mathrm{~K}$ & 03E \\
\hline $87 \mathrm{~V}-09$ & 211.2 & 4D & $03 E$ & $87 V-10$ & 244.5 & $4 \mathrm{E}$ & 03E \\
\hline $87 \mathrm{~V}-09$ & 258.1 & 4D & $03 E$ & $87 V-10$ & 258.6 & 4D & $03 \mathrm{E}$ \\
\hline $87 \mathrm{~V}-09$ & 297.2 & $4 C$ & 03E & & & & \\
\hline $87 V-07$ & 31.5 & 4A & 05E & $87 \mathrm{~V}-05$ & 89.8 & $4 E G$ & $07 \mathrm{E}$ \\
\hline $87 V-07$ & 39.4 & $4 G$ & $05 E$ & $87 V-05$ & 94.4 & $4 G$ & $07 \mathrm{E}$ \\
\hline $87 V-07$ & 45.3 & 4D & 05E & $87 V-05$ & 99.0 & $4 E$ & 07E \\
\hline $87 V-07$ & 91.6 & $4 \mathrm{E}$ & $05 E$ & $87 V-05$ & 136.7 & 4A & $07 E$ \\
\hline & & & & $87 V-05$ & 162.9 & $4 G$ & $07 \mathrm{E}$ \\
\hline $87 \mathrm{~V}-06$ & 123.8 & $4 \mathrm{E}$ & $07 E$ & $87 V-05$ & 181.6 & $4 \mathrm{E}$ & 07E \\
\hline $87 v-06$ & 149.2 & 4G & $07 E$ & $87 V-05$ & 191.0 & 4D & $07 \mathrm{E}$ \\
\hline $87 v-06$ & 155.0 & $4 \mathrm{E}$ & $07 E$ & $87 V-05$ & 201.5 & $4 C$ & $07 \mathrm{E}$ \\
\hline $87 v-06$ & 168.0 & $4 \mathrm{E}$ & $07 E$ & $87 V-05$ & 238.0 & $4 \mathrm{E}$ & $07 \mathrm{E}$ \\
\hline $87 V-06$ & 206.0 & $4 \mathrm{E}$ & $07 E$ & $87 V-05$ & 278.8 & 4D & $07 \mathrm{E}$ \\
\hline $87 V-06$ & 258.6 & $4 C$ & 07E & & & & \\
\hline
\end{tabular}




\section{APPENDIX 13 (CONTINOED)}

DDH DEPTH ORETYPE SECTION DDH DEPTH ORETYPE SECTION (ft.)

$\begin{array}{lrllllll}87 \mathrm{~V}-12 & 99.7 & 4 \mathrm{EG} & 10 \mathrm{E} & 87 \mathrm{~V}-25 & 110.8 & 4 \mathrm{E} & 11 \mathrm{E} \\ 87 \mathrm{~V}-12 & 214.6 & 4 \mathrm{E} & 10 \mathrm{E} & 87 \mathrm{~V}-25 & 117.5 & 4 \mathrm{E} & 11 \mathrm{E} \\ 87 \mathrm{~V}-12 & 273.3 & 4 \mathrm{G} & 10 \mathrm{E} & 87 \mathrm{~V}-25 & 129.4 & 4 \mathrm{G} & 11 \mathrm{E} \\ 87 \mathrm{~V}-12 & 291.5 & 4 \mathrm{E} & 10 \mathrm{E} & 87 \mathrm{~V}-25 & 180.4 & 4 \mathrm{E} & 11 \mathrm{E} \\ & & & & 87 \mathrm{~V}-25 & 244.9 & 4 \mathrm{E} & 11 \mathrm{E} \\ 87 \mathrm{~V}-01 & 98.2 & 4 \mathrm{G} & 14 \mathrm{E} & 87 \mathrm{~V}-14 & 33.5 & 4 \mathrm{C} & 18 \mathrm{E} \\ 87 \mathrm{~V}-01 & 118.4 & 4 \mathrm{D} & 14 \mathrm{E} & 87 \mathrm{~V}-14 & 33.5 & 4 \mathrm{C} & 18 \mathrm{E} \\ 87 \mathrm{~V}-01 & 174.2 & 4 \mathrm{D} & 14 \mathrm{E} & 87 \mathrm{~V}-14 & 56.8 & 4 \mathrm{D} & 18 \mathrm{E} \\ & & & & 87 \mathrm{~V}-14 & 68.1 & 4 \mathrm{E} & 18 \mathrm{E} \\ 87 \mathrm{~V}-02 & 77.5 & 4 \mathrm{G} & 14 \mathrm{E} & 87 \mathrm{~V}-17 & 27.0 & 4 \mathrm{G} & 21 \mathrm{E} \\ 87 \mathrm{~V}-02 & 105.5 & 4 \mathrm{G} & 14 \mathrm{E} & 87 \mathrm{~V}-17 & 53.5 & 4 \mathrm{E} & 21 \mathrm{E} \\ 87 \mathrm{~V}-02 & 121.1 & 4 \mathrm{E} & 14 \mathrm{E} & 87 \mathrm{~V}-17 & 62.4 & 4 \mathrm{CD} & 21 \mathrm{E} \\ 87 \mathrm{~V}-02 & 123.9 & 4 \mathrm{G} & 14 \mathrm{E} & & & & \\ 87 \mathrm{~V}-02 & 137.2 & 4 \mathrm{D} & 14 \mathrm{E} & & & & \\ 87 \mathrm{~V}-02 & 142.2 & 4 \mathrm{C} & 14 \mathrm{E} & & & & \\ & & & & & & & \\ 87 \mathrm{~V}-19 & 24.1 & 4 \mathrm{E} & 24 \mathrm{E} & 87 \mathrm{~V}-22 & 32.0 & 4 \mathrm{G} & 24 \mathrm{E} \\ 87 \mathrm{~V}-19 & 69.7 & 4 \mathrm{E} & 24 \mathrm{E} & 87 \mathrm{~V}-22 & 43.6 & 4 \mathrm{E} & 24 \mathrm{E} \\ 87 \mathrm{~V}-19 & 76.5 & 4 \mathrm{D} & 24 \mathrm{E} & 87 \mathrm{~V}-22 & 53.8 & 4 \mathrm{G} & 24 \mathrm{E} \\ 87 \mathrm{~V}-19 & 106.6 & 4 \mathrm{C} & 24 \mathrm{E} & 87 \mathrm{~V}-22 & 53.8 & 4 \mathrm{G} & 24 \mathrm{E} \\ 87 \mathrm{~V}-20 & 62.5 & 4 \mathrm{E} & 24 \mathrm{E} & 87 \mathrm{~V}-22 & 82.5 & 4 \mathrm{E} & 24 \mathrm{E} \\ 87 \mathrm{~V}-20 & 76.6 & 4 \mathrm{~A} & 24 \mathrm{E} & & & & \end{array}$




\section{APPENDIX 14}

\section{COMPOSITION OF SPHALERITE IN VANGORDA ORE (WT\%)}

\begin{tabular}{|c|c|c|c|c|c|c|c|c|c|c|c|}
\hline anal. & $2 n$ & $\mathrm{Fe}$ & Mn & $\mathbf{s}$ & total & anal. & $2 n$ & $\mathrm{Fe}$ & Mn & $\mathbf{s}$ & total \\
\hline $\begin{array}{c}1 \\
2 \\
3 \\
4 \\
5 \\
6 \\
7 \\
8 \\
9 \\
10 \\
11 \\
12 \\
13 \\
14 \\
15 \\
16 \\
17 \\
18 \\
19 \\
20 \\
21 \\
22 \\
23 \\
24\end{array}$ & $\begin{array}{l}61.8 \\
59.5 \\
59.6 \\
55.3 \\
56.8 \\
59.2 \\
55.9 \\
59.0 \\
56.3 \\
56.2 \\
53.2 \\
62.5 \\
57.2 \\
58.6 \\
56.7 \\
59.1 \\
55.0 \\
56.8 \\
64.1 \\
58.2 \\
52.8 \\
59.6 \\
58.2 \\
59.9\end{array}$ & $\begin{array}{r}6.4 \\
7.6 \\
8.1 \\
10.4 \\
9.4 \\
7.3 \\
9.9 \\
8.5 \\
8.4 \\
10.2 \\
9.0 \\
5.1 \\
9.2 \\
7.8 \\
8.9 \\
7.4 \\
10.4 \\
9.4 \\
3.8 \\
8.9 \\
9.3 \\
6.0 \\
6.9 \\
6.3\end{array}$ & $\begin{array}{l}0.2 \\
0.0 \\
0.2 \\
1.0 \\
0.1 \\
0.2 \\
0.4 \\
0.2 \\
0.6 \\
1.1 \\
3.7 \\
0.3 \\
0.2 \\
0.4 \\
1.0 \\
0.1 \\
1.1 \\
0.1 \\
0.2 \\
0.0 \\
3.7 \\
0.1 \\
0.1 \\
0.1\end{array}$ & $\begin{array}{l}32.7 \\
33.3 \\
33.3 \\
33.2 \\
33.7 \\
33.5 \\
33.4 \\
33.5 \\
33.5 \\
34.4 \\
33.5 \\
33.6 \\
33.4 \\
33.3 \\
32.9 \\
33.5 \\
33.6 \\
33.6 \\
33.1 \\
33.8 \\
33.7 \\
33.1 \\
33.2 \\
33.5\end{array}$ & $\begin{array}{r}101.1 \\
100.3 \\
101.2 \\
100.0 \\
100.0 \\
100.2 \\
99.5 \\
101.1 \\
98.6 \\
101.9 \\
99.4 \\
101.5 \\
100.0 \\
100.1 \\
99.4 \\
100.1 \\
100.0 \\
99.9 \\
101.2 \\
100.9 \\
99.4 \\
98.8 \\
98.5 \\
99.9\end{array}$ & $\begin{array}{l}25 \\
26 \\
27 \\
28 \\
29 \\
30 \\
31 \\
32 \\
33 \\
34 \\
35 \\
36 \\
37 \\
38 \\
39 \\
40 \\
41 \\
42 \\
43 \\
44 \\
45 \\
46 \\
47 \\
48\end{array}$ & $\begin{array}{l}56.0 \\
58.3 \\
58.0 \\
59.2 \\
56.6 \\
55.9 \\
56.9 \\
54.4 \\
57.2 \\
62.2 \\
58.7 \\
61.6 \\
57.1 \\
57.2 \\
57.8 \\
58.8 \\
57.6 \\
57.1 \\
63.0 \\
57.1 \\
59.6 \\
63.6 \\
62.2 \\
59.1\end{array}$ & $\begin{array}{l}8.9 \\
8.1 \\
7.2 \\
7.1 \\
9.0 \\
8.9 \\
8.8 \\
8.3 \\
7.5 \\
4.6 \\
7.8 \\
5.0 \\
8.5 \\
8.3 \\
8.2 \\
5.8 \\
8.1 \\
8.4 \\
3.4 \\
8.3 \\
6.2 \\
3.9 \\
4.4 \\
6.2\end{array}$ & $\begin{array}{l}1.1 \\
0.1 \\
0.1 \\
0.0 \\
0.4 \\
1.1 \\
0.2 \\
2.0 \\
0.4 \\
0.2 \\
0.1 \\
0.2 \\
0.2 \\
0.5 \\
0.2 \\
0.7 \\
0.1 \\
0.1 \\
0.1 \\
0.1 \\
0.3 \\
0.2 \\
0.2 \\
1.4\end{array}$ & $\begin{array}{l}33.5 \\
33.5 \\
33.5 \\
33.3 \\
33.9 \\
33.9 \\
33.9 \\
34.4 \\
33.3 \\
33.3 \\
33.5 \\
33.3 \\
33.6 \\
33.6 \\
33.4 \\
33.2 \\
33.7 \\
33.7 \\
32.8 \\
33.4 \\
33.4 \\
33.2 \\
33.3 \\
33.4\end{array}$ & $\begin{array}{r}99.4 \\
99.9 \\
98.7 \\
99.6 \\
99.8 \\
99.8 \\
99.8 \\
99.1 \\
98.4 \\
100.2 \\
100.1 \\
100.2 \\
99.4 \\
99.5 \\
99.6 \\
98.5 \\
99.4 \\
99.3 \\
99.3 \\
98.9 \\
99.5 \\
100.8 \\
100.0 \\
100.0\end{array}$ \\
\hline \multicolumn{7}{|c|}{$\begin{array}{l}\text { Mean }= \\
\text { Max }= \\
\text { Min }= \\
\text { Std dev }=\end{array}$} & $\begin{array}{r}58.3 \\
64.1 \\
52.8 \\
2.5\end{array}$ & $\begin{array}{r}7.6 \\
10.4 \\
3.4 \\
1.8\end{array}$ & $\begin{array}{l}0.5 \\
3.7 \\
0.0 \\
0.8\end{array}$ & $\begin{array}{r}33.4 \\
34.4 \\
32.7 \\
0.3\end{array}$ & \\
\hline
\end{tabular}

All analyses from final zinc conc.

Accelerating Voltage $20.0 \mathrm{Kv}$, Beam Current $20 \mathrm{~mA}$, counting times 100 seconds, standards and $X$-ray emission lines used are sphalerite with $9.49 \%$ Fe (ZnK., FeK., SKa) and Mns (MnKa), ZAF correction applied. 


\section{APPENDIX 15}

TRACE ELEMENT CONTENT OF GALENA IN VANGORDA ORE*'(PPM)

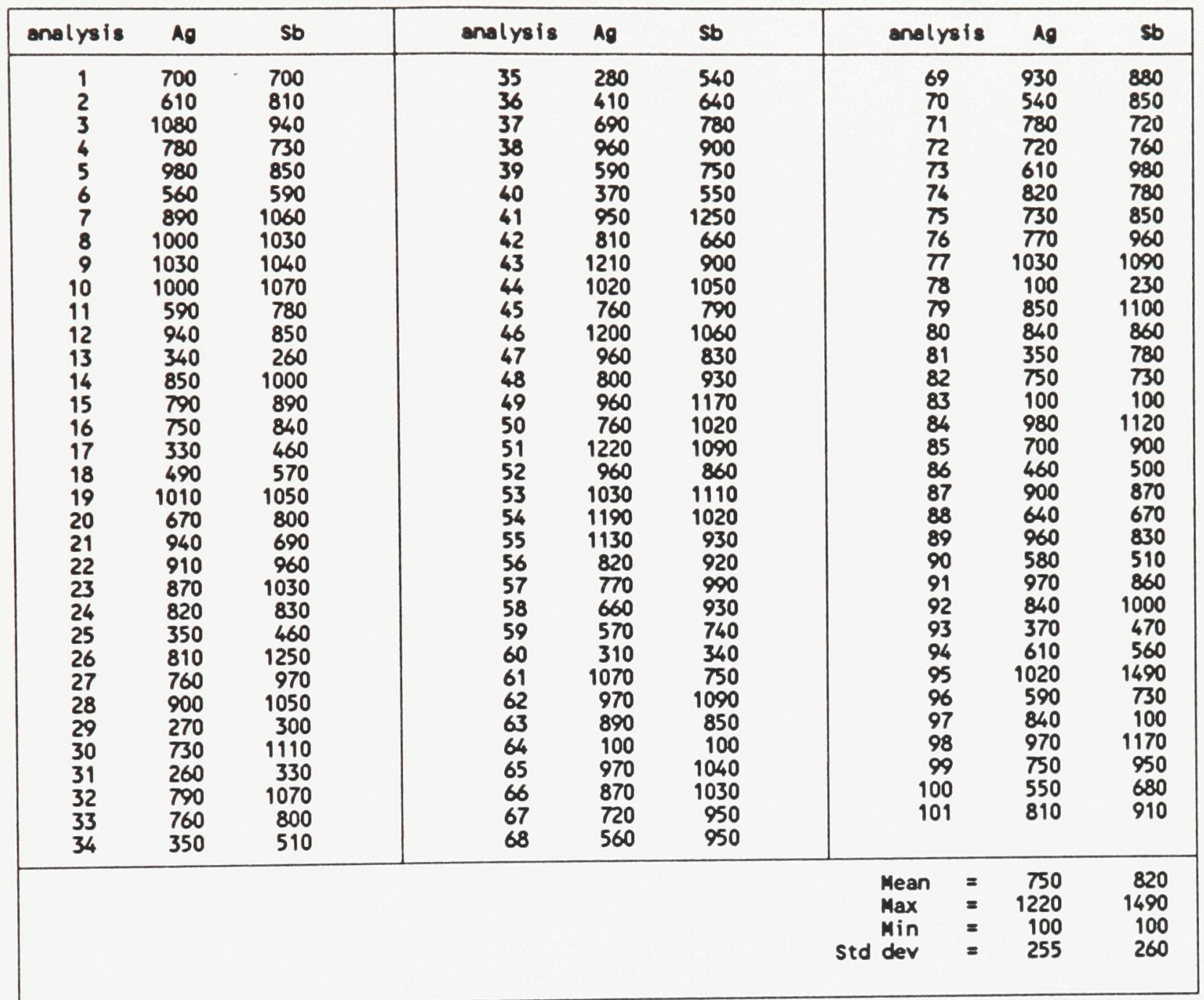

Each analyses a single spot. All analyses from final lead conc.

As and $\mathrm{Bi}$ not detected. Accelerating Voltage $20.0 \mathrm{Kv}$, Beam Current $40 \mathrm{~m}$, counting times 100 seconds, standards and $X$-ray emission lines used are galena with $0.40 \%$ Ag (AgL.), enargite (AsL, ), $B i_{2} S_{3}\left(B i M_{e}\right)$, tetrahedrite $\left(S L_{e}\right)$, backgrounds on pure PbS. Minimum detection limit $A g=250$ ppm, Sb=200 ppm, As=230 ppm, Bi=700 ppm. 


\section{APPENDIX 16}

COMPOSITIONS OF TETRAHEDRITE-TENNANTITE IN VANGORDA ORE (WT\%)

\begin{tabular}{rrrlrrrrr} 
Anal & Cu & Ag & Fe & Zn & \multicolumn{1}{l}{ Sb } & As & S & total \\
1 & 39.98 & 1.77 & 6.21 & 1.87 & 3.92 & 17.79 & 27.75 & 99.29 \\
2 & 39.78 & 2.19 & 6.81 & 1.79 & 5.33 & 16.55 & 27.44 & 99.89 \\
3 & 41.18 & 1.35 & 5.63 & 2.89 & 3.92 & 17.65 & 27.59 & 100.21 \\
4 & 32.82 & 3.57 & 4.25 & 11.15 & 14.02 & 9.02 & 26.77 & 101.60 \\
5 & 38.43 & 2.17 & 5.34 & 3.01 & 12.82 & 11.70 & 26.25 & 99.72 \\
6 & 38.47 & 2.19 & 5.02 & 3.94 & 12.82 & 11.65 & 26.51 & 100.60 \\
7 & 37.68 & 2.49 & 4.96 & 3.43 & 16.35 & 8.03 & 25.41 & 98.35 \\
8 & 37.67 & 2.44 & 4.41 & 3.85 & 14.28 & 10.17 & 26.36 & 99.18 \\
9 & 38.02 & 2.47 & 3.96 & 3.59 & 17.03 & 8.78 & 26.05 & 99.90 \\
10 & 38.65 & 2.15 & 4.29 & 3.16 & 13.15 & 11.31 & 26.30 & 99.01 \\
11 & 38.73 & 2.45 & 4.28 & 3.32 & 14.71 & 9.99 & 26.14 & 99.62 \\
12 & 39.05 & 2.32 & 4.18 & 3.39 & 14.86 & 10.02 & 26.00 & 99.82 \\
13 & 38.28 & 2.91 & 4.31 & 3.43 & 14.38 & 10.38 & 26.37 & 100.06 \\
14 & 38.19 & 3.03 & 4.59 & 3.86 & 12.54 & 12.11 & 26.34 & 100.66 \\
15 & 40.40 & 2.09 & 5.36 & 3.43 & 3.94 & 17.69 & 27.23 & 100.14 \\
16 & 37.50 & 3.87 & 4.45 & 3.40 & 12.00 & 12.24 & 26.31 & 99.77 \\
17 & 41.06 & 1.27 & 5.13 & 2.99 & 4.04 & 17.41 & 27.22 & 98.12 \\
18 & 41.12 & 1.69 & 5.08 & 3.42 & 4.88 & 16.67 & 27.61 & 100.47 \\
19 & 40.82 & 1.64 & 3.96 & 4.54 & 1.21 & 20.01 & 27.64 & 99.82 \\
20 & 41.21 & 1.59 & 3.74 & 4.54 & 1.16 & 29.74 & 27.04 & 99.02 \\
21 & 40.19 & 2.14 & 3.47 & 4.90 & 3.93 & 17.62 & 26.83 & 99.08 \\
22 & 39.69 & 2.09 & 3.95 & 4.70 & 4.78 & 17.16 & 26.74 & 99.11 \\
& & & & & & & & \\
AVG & 39.04 & 2.27 & 4.70 & 3.85 & 9.37 & 13.80 & 26.72 & 99.75 \\
MAX & 41.21 & 3.87 & 6.81 & 11.15 & 17.03 & 20.01 & 27.75 & 101.60 \\
MIN & 32.82 & 1.27 & 3.47 & 1.79 & 1.16 & 8.03 & 25.41 & 98.35 \\
STD & 1.83 & 0.63 & 0.80 & 1.77 & 5.35 & 3.87 & 0.63 & 0.70
\end{tabular}

'Analyses 1 to 18 from $87 \mathrm{~V} 11$ 195.0', 19 to 22 from $87 \mathrm{~V} 11$

Accelerating Voltage $20.0 \mathrm{Kv}$, Beam Current $15 \mathrm{nA}$, counting times 100 seconds, standards and X-ray emission lines used are tetrahedrite with $3.37 \% \mathrm{Fe}\left(\mathrm{CuK}_{\mathrm{a}}, \mathrm{FeK}_{\mathrm{\prime}}, \mathrm{SbL}_{\mathrm{a}}, \mathrm{SK}_{\mathrm{a}}\right)$, Ag metal $\left(\mathrm{AgL}_{\mathrm{a}}\right)$, sphalerite with $4.7 \% \mathrm{Fe}\left(\mathrm{ZnK}_{\mathrm{s}}\right)$ and enargite $\left(\mathrm{ASL}_{\mathrm{a}}\right), \mathrm{ZAF}$ correction applied. 


\section{APPENDIX 17}

MICROPROBE ANALYSES OF VANGORDA CARBONATES (WTף)*

1

$\begin{array}{rr}\text { Feo } & 7.87 \\ \mathrm{Mno} & 0.49 \\ \mathrm{Zno} & 0.01 \\ \mathrm{Mgo} & 17.31 \\ \mathrm{CaO} & 27.27 \\ \mathrm{BaO} & 0.00 \\ \mathrm{CO}_{2}{ }^{*} & 47.05\end{array}$

$\mathrm{Ca}_{47} \mathrm{Mg}_{.42} \mathrm{Fe}_{.11}$

5

$\begin{array}{rr}\text { Feo } & 17.53 \\ \mathrm{MnO} & 3.56 \\ \mathrm{ZnO} & 0.00 \\ \mathrm{MgO} & 6.98 \\ \mathrm{CaO} & 24.16 \\ \mathrm{BaO} & 0.07 \\ \mathrm{CO}_{2}{ }^{*} & 47.70\end{array}$

$\mathrm{Ca}_{{ }_{18}} \mathrm{Fe}_{27} \mathrm{Mg}_{\mathrm{g}_{19}} \mathrm{Mn}_{.6} \mathrm{CO}_{3}$

9

FeO 21.87

Mno 5.66

Zno 0.09

Mgo 1.91

CaO 24.78

$\mathrm{BaO} \quad 0.08$

$\mathrm{CO}_{2}{ }^{*} 45.61$

$\mathrm{Ca}_{31} \mathrm{Fe}_{39} \mathrm{Mn}_{.09} \mathrm{MBg}_{8.03} \mathrm{CO}_{3}$
2

$$
\begin{array}{r}
7.42 \\
17.06 \\
0.00 \\
7.88 \\
23.62 \\
0.02 \\
44.00
\end{array}
$$

$\mathrm{Ca}_{{ }_{33}} \mathrm{Mn}_{23} \mathrm{Mg}_{.21} \mathrm{Fe}_{.11} \mathrm{CO}$,

6

15.24

1.52

0.00

9.61

27.24

0.00

46.39

$\mathrm{Ca}_{31} \mathrm{Mg}_{22} \mathrm{Fe}_{22} \mathrm{Mn}_{22} \mathrm{CO}$

10

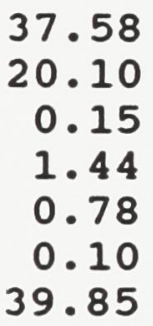

$\mathrm{Fe}_{.61} \mathrm{Mn}_{33} \mathrm{Mg}_{8.4} \mathrm{Cl}_{\mathbf{s}_{22}} \mathrm{CO}$,
3

4

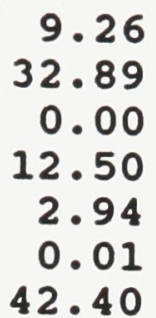

19.32

1.36

0.02

7.68

24.93

0.04

46.65

$\mathrm{Mn}_{90} \mathrm{Mg}_{32} \mathrm{Fe}_{.1} \mathrm{Cl}_{205} \mathrm{CO}_{3}$

$\mathrm{Ca}_{43} \mathrm{Fe}_{2.2} \mathrm{Mg}_{8.21} \mathrm{Mn}_{22} \mathrm{CO}$,

7

8

19.25

7.00

0.12

4.23

23.84

0.02

45.54

19.00

23.28

0.06

13.70

0.94

0.00

43.02

$\mathrm{Ca}_{47} \mathrm{Fe}_{30} \mathrm{Mg}_{12} \mathrm{Mn}_{11} \mathrm{CO}_{3}$

$\mathrm{MB}_{36} \mathrm{Mn}_{3 y} \mathrm{Fe}_{2 y} \mathrm{C}_{x_{21}} \mathrm{CO}_{3}$

11

12

$$
\begin{array}{r}
16.65 \\
2.57 \\
0.05 \\
8.64 \\
24.71 \\
0.00 \\
47.38
\end{array}
$$

14.91

30.07

0.12

10.11

1.61

0.02

43.16

$\mathrm{Ca}_{\boldsymbol{x}_{3}} \mathrm{Fe}_{2,} \mathrm{Mg}_{\mathbf{g}_{2}} \mathrm{Mn}_{.4} \mathrm{CO}$

$\mathrm{Mn}_{A_{7}} \mathrm{Mg}_{27} \mathrm{Fe}_{22} \mathrm{Ca}_{x_{31}} \mathrm{CO}$, 
13 14 15

16

$\begin{array}{lr}\mathrm{FeO} & 1.81 \\ \mathrm{MnO} & 8.02 \\ \mathrm{ZnO} & 0.00 \\ \mathrm{MgO} & 16.10 \\ \mathrm{CaO} & 26.79 \\ \mathrm{BaO} & 0.00 \\ \mathrm{CO}_{2}{ }^{*} & 47.28 \\ \mathrm{Ca}_{3} \mathrm{Mg}_{3,} \mathrm{Mn}_{{ }_{11} \mathrm{Fe}_{.2} \mathrm{CO},}\end{array}$

$$
\begin{array}{r}
18.68 \\
2.22 \\
0.00 \\
10.20 \\
27.17 \\
0.02 \\
41.71
\end{array}
$$

$\mathrm{Ca}_{A_{3}} \mathrm{Fe}_{2} \mathrm{MB}_{\mathrm{B}_{2}} \mathrm{Mn}_{{ }_{50}} \mathrm{CO}$,

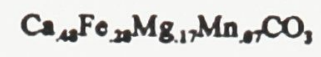

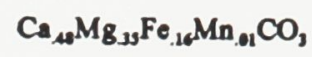

17

18

19

20

$\begin{array}{rr}\text { Feo } & 7.53 \\ \text { Mno } & 15.46 \\ \text { Zno } & 0.07 \\ \text { Mgo } & 8.70 \\ \mathrm{CaO} & 24.05 \\ \mathrm{BaO} & 0.02 \\ \mathrm{CO}_{2}{ }^{*} & \mathbf{4 4 . 1 7}\end{array}$

15.66

3.90

0.00

7.49

23.83

0.00

49.12

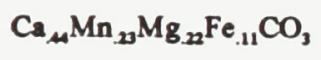

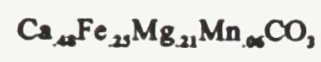

9.73

0.81

18.11

0.00

2.71

14.97

0.00

25.73

7.77

0.00

23.66

48.76

0.00

47.75

21

22

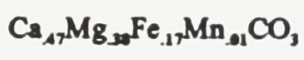

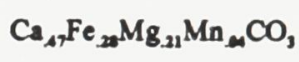

23

Feo 40.85

Mno 4.97

45.07

4.33

9.67

0.15

0.71

0.10

39.97

46.12

3.16

3.76

0.35

4.37

0.09

$\mathrm{CO}_{2}^{*} 37.88$

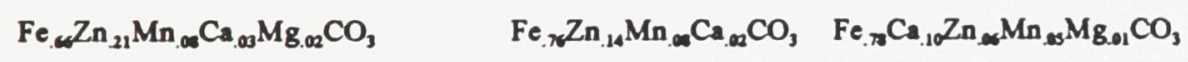

- Accelerating Voltage $13.0 \mathrm{Kv}$, Beam Current $10 \mathrm{nA}$, counting times 60 seconds, standards and X-ray emission lines used are dolomite $\left(\mathrm{CaK}_{\mathrm{a}}, \mathrm{MgK}_{\mathrm{s}}\right)$, rhodochrosite $\left(\mathrm{MnK}_{\mathrm{a}}\right)$, $\mathrm{Zn}$ ferrite $\left(\mathrm{ZnK}_{\mathrm{a}}, \mathrm{FeK}_{\mathrm{s}}\right)$ and barite $\left(\mathrm{BaL}_{\mathrm{a}}\right)$, $\mathrm{ZAF}$ correction applied. All analyses from final zinc tails.

** by difference 
APPENDIX 18

VANGORDA CONCENTRATOR SOLID FLOWRATES (TPH) LEAD CIRCUIT

\begin{tabular}{|c|c|c|}
\hline stream & Measured & Balanced \\
\hline ROUGHER FEED & 534.00 & $\frac{533.85}{533}$ \\
\hline ROUGHER CONCENTRATE G+H & - & 39.07 \\
\hline ROUGHER CONCENTRATE I & - & 16.34 \\
\hline ROUGHER TAIL G+H & - & 494.77 \\
\hline SCAVENGER CONCENTRATE I & - & 72.41 \\
\hline ROUGHER TAIL I & - & 106.77 \\
\hline SCAVENGER CONCENTRATE G+H & - & 16.51 \\
\hline SCAVENGER TAIL G+H & - & 478.27 \\
\hline SCAVENGER CONCENTRATE COMB. & - & 88.91 \\
\hline SCAVENGER TAIL I & - & 34.36 \\
\hline TAILS & - & 512.63 \\
\hline CYCLONE UNDERFLOW & - & 205.13 \\
\hline REGRIND DISCHARGE & - & 205.13 \\
\hline CYCLONE OVERFLOW & - & 55.41 \\
\hline SCAVENGER CYCLONE UNDERFLOW & - & 106.77 \\
\hline SCAVENGER REGRIND DISCHARGE & - & 106.77 \\
\hline SCAVENGER CYCLONE OVERFLOW & - & 123.11 \\
\hline FIRST CLEANER CONCENTRATE & - & 57.81 \\
\hline SECOND CLEANER CONCENTRATE & - & 77.84 \\
\hline THIRD CLEANER CONCENTRATE & - & 21.22 \\
\hline FIRST CLEANER TAIL & - & 34.19 \\
\hline SECOND CLEANER TAIL & - & 36.60 \\
\hline THIRD CLEANER TAIL & - & 55.62 \\
\hline \multicolumn{3}{|c|}{ ZINC CIRCUIT } \\
\hline Stream & Measured & Balanced \\
\hline FEED & - & 512.63 \\
\hline ROUGHER FEED L+K & - & 552.80 \\
\hline ROUGHER CONCENTRATE L+K & - & 87.93 \\
\hline ROUGHER TAIL L+K & - & 464.87 \\
\hline ROUGHER CONCENTRATE L+K & - & 87.93 \\
\hline SCAVENGER CONCENTRATE L+K & - & 40.17 \\
\hline SCAVENGER TAIL L+K & - & 424.70 \\
\hline REGRIND CYCLONE UNDERFLOW & - & 303.12 \\
\hline REGRIND DISCHARGE & - & 303.12 \\
\hline REGRIND CYCLONE OVERFLOW & - & 87.93 \\
\hline ROUGHER CONCENTRATE J & - & 170.29 \\
\hline ROUGHER TAIL J & - & 102.91 \\
\hline SCAVENGER CONCENTRATE $J$ & - & 59.78 \\
\hline SCAVENGER TAIL J & - & 43.13 \\
\hline ROUGHER COLUMN CONCENTRATE & - & 31.21 \\
\hline ROUGHER COLUMN TAIL & - & 198.86 \\
\hline SCAVENGER COLUMN CONCENTRATE & - & 13.59 \\
\hline $\begin{array}{l}\text { SCAVENGER COLUMN TAIL } \\
\text { SCR }\end{array}$ & - & 185.27 \\
\hline ZINC CONCENTRATE & - & 44.80 \\
\hline FINAL TAILS & - & 467.83 \\
\hline
\end{tabular}




\section{APPENDIX 19}

VANGORDA CONCENTRATOR MEASURED NMD BALANCED STREAM ASSAYS AND DISTRIBUTION (X)

LEAD CIRCUIT

LEAD (WTX)

ZINC (UT

SILVER (PPW)

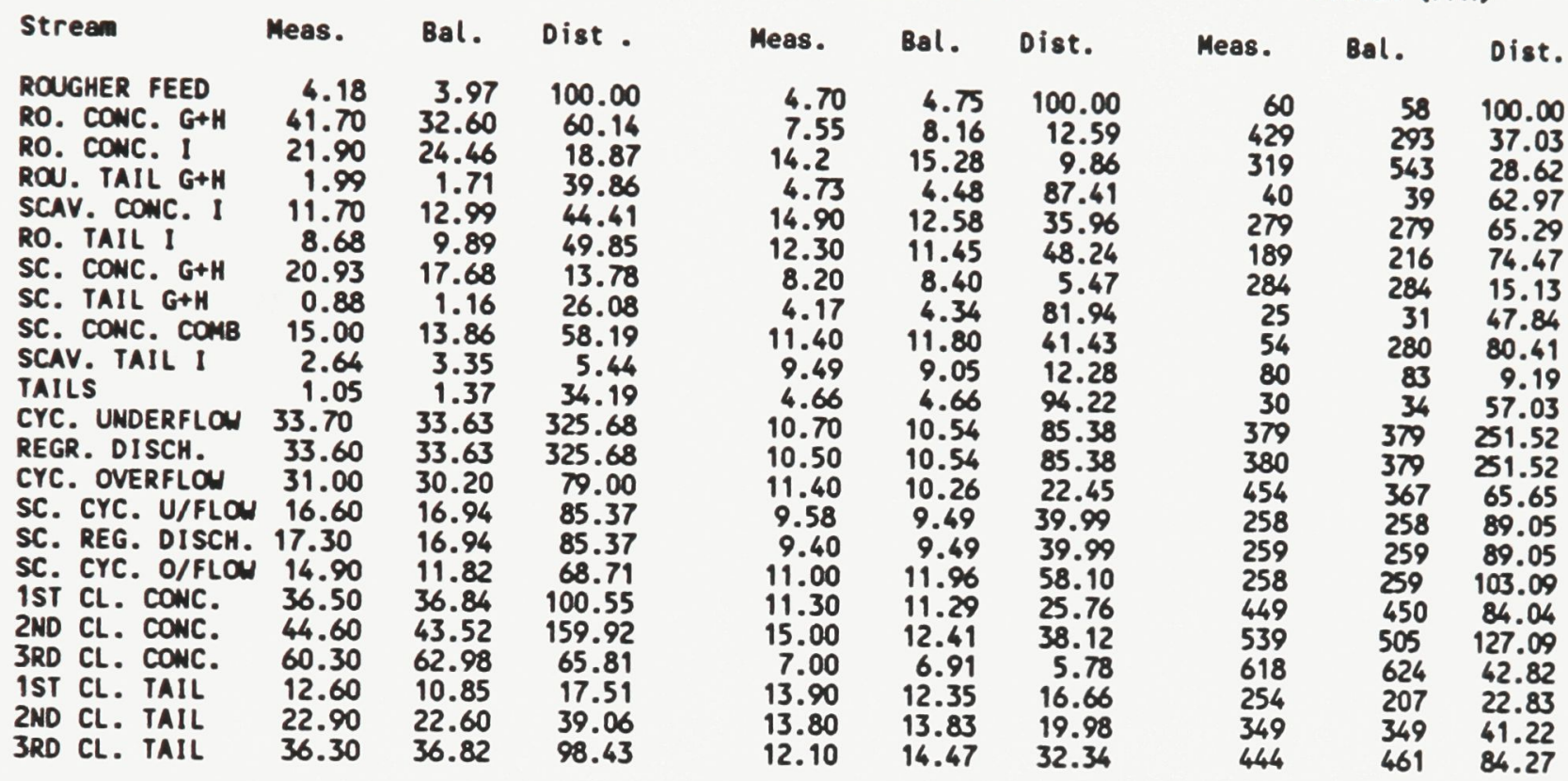

ZINC CIRCUIT

LEAD(WTX)

$\begin{array}{lccc}\text { Stream } & \text { Meas. } & \text { Bal. } & \text { Dist. } \\ \text { FEED } & 1.30 & 1.10 & 100.00 \\ \text { RO. FEED L+K } & 1.17 & 1.30 & 127.18 \\ \text { RO. CONC. L+K } & 4.05 & 3.65 & 57.02 \\ \text { RO. TAIL L+K } & 0.80 & 0.85 & 70.16 \\ \text { RO. CONC. L+K } & 3.71 & 3.65 & 57.02 \\ \text { SC. CONC. L+K } & 4.03 & 3.81 & 27.18 \\ \text { SC. TAIL L+K } & 0.52 & 0.57 & 42.98 \\ \text { REG. CYC. U/F } & 4.55 & 4.55 & 244.58 \\ \text { REG. DISCHARGE } & 4.54 & 4.55 & 244.58 \\ \text { REG. CYC. O/F } & 3.05 & 3.65 & 57.02 \\ \text { RO. CONC. J } & 5.52 & 5.55 & 167.85 \\ \text { ROUGHER TAIL J } & 5.40 & 5.28 & 96.52 \\ \text { SC. CONC. J } & 6.67 & 6.79 & 72.06 \\ \text { SC. TAIL J } & 3.10 & 3.20 & 24.46 \\ \text { RO. COL. CONC. } & 4.16 & 4.35 & 24.12 \\ \text { RO. COL. TAIL } & 5.91 & 6.11 & 215.79 \\ \text { SC. COL. CONC. } & 3.44 & 3.50 & 8.43 \\ \text { SC. COL. TAIL } & 6.65 & 6.30 & 207.35 \\ \text { ZINC CONC. } & 4.04 & 4.09 & 32.55 \\ \text { FINAL TAIL } & 0.66 & 0.81 & 67.45\end{array}$

ZINC(WTX)

Meas.
4.66
4.54
25.80
1.37
28.90
10.04
0.61
23.80
22.90
27.90
36.50
18.80
24.70
5.84
48.20
35.10
51.60
31.70
48.90
0.89

$\begin{array}{rr}\text { Bal. } & \text { Dist. } \\ 5.17 & 100.00 \\ 5.50 & 114.77 \\ 27.41 & 90.91 \\ 1.36 & 23.85 \\ 27.41 & 90.91 \\ 9.74 & 14.77 \\ 0.57 & 9.09 \\ 23.33 & 266.83 \\ 23.33 & 266.83 \\ 27.41 & 90.91 \\ 37.67 & 242.02 \\ 17.52 & 68.03 \\ 26.21 & 59.12 \\ 5.48 & 8.91 \\ 47.30 & 55.69 \\ 32.71 & 245.45 \\ 51.31 & 26.31 \\ 31.35 & 219.13 \\ 48.52 & 82.00 \\ 1.02 & 18.00\end{array}$

SILVER (PPH)

$\begin{array}{rrr}\text { Meas. } & \text { Bal. } & \text { Dist. } \\ 37 & 24 & 100.00 \\ 25 & 27 & 123.34 \\ 81 & 75 & 54.51 \\ 17 & 18 & 68.84 \\ 78 & 75 & 54.51 \\ 73 & 70 & 23.34 \\ 11 & 13 & 45.49 \\ 83 & 83 & 207.27 \\ 82 & 83 & 207.27 \\ 72 & 75 & 54.51 \\ 104 & 104 & 145.88 \\ 90 & 91 & 77.41 \\ 115 & 113 & 56.11 \\ 54 & 60 & 21.29 \\ 89 & 92 & 23.67 \\ 109 & 108 & 178.32 \\ 84 & 85 & 9.54 \\ 109 & 110 & 168.78 \\ 86 & 90 & 33.21 \\ 25 & 17 & 66.79\end{array}$




\section{APPENDIX 19 (CONTINUED)}

LEAD CIRCUIT

ANTIMONY (PPM)

$\begin{array}{lrrr}\text { Stream } & \text { Meas. } & \text { Bal. } & \text { Dist. } \\ \text { ROUGHER FEED } & 100 & 136 & 100.00 \\ \text { RO. CONC. G+H } & 700 & 681 & 36.64 \\ \text { RO. CONC. I } & 400 & 516 & 11.61 \\ \text { RO. TAIL G+H } & 100 & 93 & 63.36 \\ \text { SC. CONC.I } & 300 & 247 & 24.67 \\ \text { RO. TAIL I } & 200 & 204 & 30.06 \\ \text { SC. CONC. G+H } & 600 & 295 & 6.71 \\ \text { SC. TAIL G+H } & 100 & 86 & 56.65 \\ \text { SC. CONC. CONB } & 200 & 256 & 31.38 \\ \text { SC. TAILI } & 100 & 114 & 5.39 \\ \text { TAILS } & 100 & 88 & 62.04 \\ \text { CYC. UIFLOH } & 100 & 112 & 31.65 \\ \text { REG. DISCH. } & 700 & 112 & 31.65 \\ \text { CYC. OVERFLO } & 700 & 632 & 48.24 \\ \text { SC. CYC. U/F } & 500 & 511 & 75.12 \\ \text { SC. REG. DIS. } & 500 & 511 & 75.12 \\ \text { SC. CYC. O/F } & 400 & 246 & 41.66 \\ \text { IST CL. CONC. } & 800 & 766 & 60.99 \\ \text { 2ND CL. CONC. } & 1000 & 1006 & 107.89 \\ \text { 3RD CL. CONC. } & 1400 & 1300 & 37.96 \\ \text { IST CL. TAIL } & 450 & 218 & 10.28 \\ \text { 2ND CL. TAIL } & 450 & 457 & 23.03 \\ \text { 3RD CL. TAIL } & 900 & 896 & 69.92 \\ & & & \end{array}$

COPPER (UTY)

\begin{tabular}{lrr} 
Mes. & B.l. & \multicolumn{1}{l}{ Dist. } \\
0.17 & 0.18 & 100.00 \\
0.25 & 0.29 & 11.43 \\
0.84 & 1.01 & 16.87 \\
0.19 & 0.18 & 88.57 \\
2.85 & 2.17 & 160.30 \\
1.78 & 1.70 & 185.47 \\
0.87 & 1.06 & 17.94 \\
0.13 & 0.14 & 70.64 \\
1.76 & 1.96 & 178.24 \\
0.88 & 0.72 & 25.17 \\
0.25 & 0.18 & 95.80 \\
0.35 & 0.34 & 71.85 \\
0.34 & 0.34 & 71.85 \\
0.61 & 0.50 & 28.29 \\
0.76 & 0.70 & 76.70 \\
0.66 & 0.70 & 76.70 \\
1.69 & 1.61 & 202.34 \\
0.44 & 0.45 & 26.42 \\
0.34 & 0.36 & 28.64 \\
0.22 & 0.21 & 4.59 \\
0.98 & 0.68 & 23.70 \\
0.62 & 0.58 & 21.83 \\
0.44 & 0.42 & 24.05 \\
& &
\end{tabular}

COLD (PPM)

$\begin{array}{rrr}\text { Meas. } & \text { Bal. } & \text { Dist. } \\ 0.65 & 0.67 & 100.00 \\ 2.95 & 2.16 & 23.82 \\ 3.84 & 5.51 & 25.36 \\ 0.69 & 0.55 & 76.18 \\ 2.67 & 4.45 & 90.82 \\ 1.96 & 3.43 & 103.21 \\ 3.77 & 3.83 & 17.82 \\ 0.42 & 0.43 & 58.36 \\ 3.98 & 4.34 & 108.64 \\ 0.51 & 1.28 & 12.39 \\ 0.45 & 0.49 & 70.74 \\ 9.26 & 9.44 & 545.56 \\ 9.64 & 9.44 & 545.53 \\ 3.39 & 3.15 & 49.13 \\ 31.21 & 31.21 & 938.54 \\ 31.60 & 31.21 & 938.53 \\ 5.14 & 3.71 & 128.57 \\ 4.22 & 3.85 & 62.74 \\ 4.90 & 4.73 & 103.62 \\ 4.56 & 4.60 & 27.49 \\ 1.92 & 2.25 & 21.64 \\ 3.28 & 3.42 & 35.25 \\ 4.66 & 4.77 & 76.13\end{array}$

ZINC CIRCUIT

ANTIMONY (PPM)

COPPER (WTY)

GOLD (PPM)

\begin{tabular}{|c|c|c|c|c|c|c|c|c|c|}
\hline stream & Meas. & Bal. & Dist. & Meas. & Bal. & Dist. & Meas. & Bal. & Dist. \\
\hline $\begin{array}{l}\text { FEED } \\
\text { RO. FEED L+K } \\
\text { RO. CONC. L+K } \\
\text { RO. TAIL L+K } \\
\text { RO. CONC. L+K } \\
\text { SC. CONC. L+K } \\
\text { SC. TAIL L+K } \\
\text { REG. CYC. U/F } \\
\text { REG. DISCH. } \\
\text { REG. CYC. O/F } \\
\text { RO. CONC. J } \\
\text { RO. TAIL J } \\
\text { SC. CONC. J } \\
\text { SC. TAIL J } \\
\text { RO. COL. CONC. } \\
\text { RO. COL. TAIL } \\
\text { SC. COL. CONC. } \\
\text { SC. COL. TAIL } \\
\text { ZINC CONC. } \\
\text { FINAL TAIL }\end{array}$ & $\begin{array}{r}88 \\
50 \\
200 \\
50 \\
200 \\
100 \\
50 \\
200 \\
200 \\
100 \\
200 \\
200 \\
200 \\
200 \\
200 \\
200 \\
100 \\
200 \\
90 \\
40\end{array}$ & $\begin{array}{r}57 \\
60 \\
138 \\
45 \\
138 \\
99 \\
40 \\
200 \\
200 \\
138 \\
188 \\
188 \\
203 \\
166 \\
120 \\
203 \\
91 \\
211 \\
111 \\
51\end{array}$ & $\begin{array}{r}100.00 \\
113.71 \\
41.91 \\
71.80 \\
41.91 \\
13.71 \\
58.09 \\
208.97 \\
208.97 \\
41.91 \\
110.14 \\
66.55 \\
41.83 \\
24.72 \\
12.91 \\
139.06 \\
4.28 \\
134.78 \\
17.18 \\
82.82\end{array}$ & $\begin{array}{l}0.18 \\
0.23 \\
0.78 \\
0.12 \\
0.68 \\
0.66 \\
0.06 \\
0.55 \\
0.60 \\
0.75 \\
0.85 \\
0.85 \\
1.04 \\
0.40 \\
0.78 \\
0.87 \\
0.88 \\
0.93 \\
0.76 \\
0.07\end{array}$ & $\begin{array}{l}0.16 \\
0.20 \\
0.64 \\
0.11 \\
0.64 \\
0.70 \\
0.06 \\
0.57 \\
0.57 \\
0.64 \\
0.84 \\
0.80 \\
1.07 \\
0.43 \\
0.81 \\
0.91 \\
0.89 \\
0.92 \\
0.83 \\
0.09\end{array}$ & $\begin{array}{r}100.00 \\
134.86 \\
69.45 \\
65.41 \\
69.45 \\
34.86 \\
30.55 \\
215.88 \\
215.88 \\
69.45 \\
177.47 \\
102.86 \\
79.82 \\
23.05 \\
31.30 \\
225.99 \\
15.10 \\
210.89 \\
46.40 \\
53.60\end{array}$ & $\begin{array}{l}0.49 \\
0.55 \\
1.51 \\
0.52 \\
1.13 \\
1.86 \\
0.45 \\
3.60 \\
3.88 \\
1.13 \\
1.85 \\
1.68 \\
2.23 \\
0.79 \\
0.58 \\
1.80 \\
0.82 \\
1.96 \\
0.68 \\
0.92\end{array}$ & $\begin{array}{l}0.52 \\
0.61 \\
0.86 \\
0.57 \\
0.86 \\
1.76 \\
0.45 \\
3.73 \\
3.73 \\
0.86 \\
1.65 \\
1.67 \\
2.14 \\
1.02 \\
0.64 \\
1.95 \\
0.87 \\
2.03 \\
0.71 \\
0.51\end{array}$ & $\begin{array}{r}100.00 \\
126.31 \\
28.27 \\
98.04 \\
28.27 \\
26.31 \\
71.73 \\
421.41 \\
421.41 \\
28.27 \\
104.71 \\
64.02 \\
47.67 \\
16.35 \\
7.49 \\
144.89 \\
4.43 \\
140.47 \\
11.91 \\
88.09\end{array}$ \\
\hline
\end{tabular}




\section{APPENDIX 20}

BALANCED MINERAL OUNTITIES IN VANGORDA CONCENTRATOR (WTX)

LEAD FLOTATION CIRCUIT

$\begin{array}{cr}\text { Sphalerite } & \text { Galeno } \\ & \\ 8.43 & 4.40 \\ 15.58 & 36.11 \\ 24.71 & 33.21 \\ 7.87 & 1.90 \\ 23.12 & 15.83 \\ 21.55 & 12.16 \\ 15.15 & 17.19 \\ 7.62 & 1.38 \\ 21.64 & 16.08 \\ 18.23 & 4.43 \\ 8.33 & 1.58 \\ 18.19 & 39.39 \\ 18.19 & 39.39 \\ 18.27 & 35.25 \\ 16.67 & 21.03 \\ 16.67 & 21.03 \\ 21.97 & 14.96 \\ 19.70 & 44.04 \\ 21.18 & 50.78 \\ 10.96 & 72.70 \\ 22.81 & 12.02 \\ 24.76 & 27.44 \\ 25.00 & 42.57\end{array}$

Barite

Rougher feed

Rougher conc. gth

Rougher conc. i

Rougher tail $\mathrm{gth}$

Scavenger conc. i

Rougher tail i

Scavenger conc. $g^{+h}$

Scavenger tail $g+h$

Scavenger conc. comb.

Scavenger tail i

Tails

Cyclone underflow

Regrind discharge

Cyclone overflow

Scavenger cyc. U/flow

Scavenger reg. disch.

Scavenger cyc. o/flow

First cleaner conc.

Second cleaner conc.

Third cleaner conc.

First cleaner tail

Second cleaner tail

Third cleaner tail

\section{Chalcopyrite}

0.40

0.38

1.14

0.40

4.78

3.68

2.04

0.34

4.27

1.37

0.41

0.63

0.63

0.61

2.18

2.18

3.35

1.14

0.67

0.07

0.94

1.76

0.89
6.86

0.79

0.85

7.34

0.78

1.01

1.91

7.52

0.99

1.49

7.12

1.87

1.87

0.81

3.83

3.83

0.99

1.17

1.02

0.54

0.97

1.54

Quartz
16.08
16.37
12.02
9.02
16.37
9.05
12.74
16.93
16.35
10.52
20.52
16.63
3.19
3.19
11.38
2.96
2.96
12.25
6.74
4.27
2.73
16.75
9.06
4.84

Ankerite

2.26

2.70

3.15

2.22

4.35

4.30

4.95

2.13

4.46

4.19

2.27

1.86

1.86

2.82

2.38

2.38

4.14

3.16

2.43

2.02

3.32

3.81

2.58

Arsenopyrite

0.10

0.04

0.12

0.11

0.22

0.18

0.15

0.10

0.21

0.11

0.11

0.02

0.02

0.06

0.02

0.02

0.18

0.06

0.07

0.01

0.10

0.09

0.10
Pyrrhotite

8.47

3.09

5.36

8.90

6.33

5.55

3.72

9.08

5.85

3.88

8.73

3.34

3.34

3.76

6.26

6.26

5.52

2.83

3.07

3.30

4.67

3.14

3.36
Pyrite-

37.96

20.42

16.08

39.34

25.63

27.95

25.99

39.80

25.70

32.83

39.34

25.44

25.44

18.55

36.10

36.10

26.11

15.32

10.84

4.66

27.17

21.50

13.16

siderite-

15.03

8.53

7.60

15.57

9.90

10.88

12.22

16.00

10.27

12.95

15.51

6.06

6.06

8.48

8.58

8.58

10.56

5.84

5.60

4.80

11.27

10.93

6.33

- includes small amounts of muscovite and calcite

- includes marcasite and a small amount of magnetite. marcasite/pyrite $=1 / 9$

- includes small amounts of chlorite, celsian, biotite, rhodochrosite, rutile and apatite 


\title{
APPENDIX 20 (CONTINUED)
}

\author{
ZINC FLOTATION CIRCUIT
}

\begin{tabular}{|c|c|c|c|c|c|}
\hline & Sphalerite & Galeno & Ouartz & Ankerite & Pyrite- \\
\hline \multirow[t]{2}{*}{$\begin{array}{l}\text { Feed } \\
\text { Rougher feed } l+k \\
\text { Rougher conc. l+k } \\
\text { Rougher tail } l+k \\
\text { Scavenger conc. } l+k \\
\text { Scavenger tail } l+k \\
\text { Regrind cyc. underflow } \\
\text { Regrind discharge } \\
\text { Regrind cyc. overflow } \\
\text { Rougher concentrate j } \\
\text { Rougher tail j } \\
\text { Scavenger concentrate j } \\
\text { Scavenger tail j } \\
\text { Rougher colum conc. } \\
\text { Rougher colum tail } \\
\text { Scavenger colum conc. } \\
\text { Scavenger column tail } \\
\text { Zinc concentrate } \\
\text { Final tail }\end{array}$} & $\begin{array}{r}8.39 \\
9.00 \\
43.85 \\
2.26 \\
17.08 \\
0.92 \\
40.02 \\
40.02 \\
43.86 \\
64.11 \\
29.35 \\
45.75 \\
8.94 \\
80.67 \\
56.24 \\
87.75 \\
54.04 \\
82.83 \\
1.72\end{array}$ & $\begin{array}{l}1.55 \\
1.72 \\
4.76 \\
1.14 \\
4.01 \\
0.88 \\
5.26 \\
5.26 \\
4.74 \\
6.52 \\
6.22 \\
7.80 \\
4.26 \\
5.75 \\
7.01 \\
4.24 \\
7.21 \\
5.28 \\
1.22\end{array}$ & $\begin{array}{r}20.48 \\
19.63 \\
4.77 \\
22.59 \\
8.58 \\
23.86 \\
4.29 \\
4.29 \\
4.35 \\
3.17 \\
5.22 \\
3.14 \\
7.82 \\
0.62 \\
3.54 \\
0.18 \\
3.77 \\
0.46 \\
22.25\end{array}$ & $\begin{array}{l}3.53 \\
3.66 \\
5.17 \\
3.53 \\
5.92 \\
3.31 \\
1.68 \\
1.68 \\
4.37 \\
1.89 \\
5.66 \\
4.10 \\
7.60 \\
0.94 \\
2.68 \\
0.39 \\
2.84 \\
0.71 \\
3.74\end{array}$ & $\begin{array}{r}37.85 \\
37.61 \\
19.41 \\
41.05 \\
33.93 \\
41.69 \\
26.70 \\
26.70 \\
19.83 \\
15.17 \\
24.24 \\
17.06 \\
33.17 \\
6.17 \\
17.05 \\
2.17 \\
18.09 \\
3.49 \\
40.84\end{array}$ \\
\hline & Chalcopyrite & Barite & Arsenopyrite & Pyrrhotite & Siderite ${ }^{-}$ \\
\hline $\begin{array}{l}\text { Feed } \\
\text { Rougher feed l+k } \\
\text { Rougher conc. l+k } \\
\text { Rougher tail l+k } \\
\text { Scavenger conc. l+k } \\
\text { Scavenger tail l+k } \\
\text { Regrind cyc. underflow } \\
\text { Regrind discharge } \\
\text { Regrind cyc. overflow } \\
\text { Rougher concentrate j } \\
\text { Rougher tail j } \\
\text { Scavenger concentrate j } \\
\text { Scavenger tail j } \\
\text { Rougher colum conc. } \\
\text { Rougher colum tail } \\
\text { Scavenger colum conc. } \\
\text { Scavenger colum tail } \\
\text { Zinc concentrate } \\
\text { Final tail }\end{array}$ & $\begin{array}{l}0.24 \\
0.41 \\
1.36 \\
0.16 \\
2.13 \\
0.00 \\
1.88 \\
1.88 \\
1.68 \\
2.68 \\
2.53 \\
3.91 \\
0.81 \\
2.61 \\
3.05 \\
2.69 \\
3.08 \\
2.19 \\
0.07\end{array}$ & $\begin{array}{l}7.59 \\
7.39 \\
3.78 \\
8.01 \\
4.19 \\
8.36 \\
3.67 \\
3.67 \\
4.17 \\
2.02 \\
4.66 \\
2.50 \\
7.34 \\
0.75 \\
2.35 \\
0.38 \\
2.49 \\
0.59 \\
8.26\end{array}$ & $\begin{array}{l}0.10 \\
0.10 \\
0.03 \\
0.12 \\
0.12 \\
0.11 \\
0.28 \\
0.28 \\
0.03 \\
0.01 \\
0.05 \\
0.06 \\
0.04 \\
0.01 \\
0.03 \\
0.02 \\
0.03 \\
0.01 \\
0.11\end{array}$ & $\begin{array}{r}8.18 \\
8.19 \\
7.69 \\
7.87 \\
6.77 \\
7.97 \\
5.96 \\
5.96 \\
9.83 \\
0.88 \\
10.78 \\
5.37 \\
17.51 \\
1.46 \\
2.12 \\
0.84 \\
2.21 \\
1.08 \\
8.92\end{array}$ & $\begin{array}{r}12.09 \\
12.28 \\
9.31 \\
13.10 \\
17.26 \\
12.70 \\
10.25 \\
10.25 \\
9.31 \\
3.65 \\
12.24 \\
10.42 \\
14.46 \\
4.07 \\
5.60 \\
1.74 \\
5.88 \\
3.39 \\
12.87\end{array}$ \\
\hline
\end{tabular}




\section{APPENDIX 21}

MINERAL ASSOCIATIONS OF SPHALERITE AND GALEMA IN VANGORDA CONCENTRATOR PROOUCTS (X PERIMETER) FEED

\begin{tabular}{|c|c|c|c|c|c|c|c|c|c|}
\hline Mineral & atz & Ank & Py & $C p$ & Bar & Po & sid & Sph/Gal & Free \\
\hline $\begin{array}{l}\text { Sphalerite } \\
\text { Galens }\end{array}$ & $\begin{array}{l}0 \\
4\end{array}$ & $\stackrel{0}{1}$ & 6 & $\begin{array}{l}0 \\
0\end{array}$ & $\begin{array}{r}M{ }^{M} \\
2 \\
3\end{array}$ & $\begin{array}{l}0 \\
1\end{array}$ & $\begin{array}{l}3 \\
8\end{array}$ & 9 & $\begin{array}{l}87 \\
68\end{array}$ \\
\hline $\begin{array}{l}\text { Sphalerite } \\
\text { Galena }\end{array}$ & $\begin{array}{l}0 \\
1\end{array}$ & $\begin{array}{l}1 \\
1\end{array}$ & $\begin{array}{l}3 \\
7\end{array}$ & $\begin{array}{l}0 \\
0\end{array}$ & $\begin{array}{r}\mu M \\
2 \\
1\end{array}$ & $\begin{array}{l}1 \\
1\end{array}$ & 2 & $\begin{array}{r}6 \\
12\end{array}$ & $\begin{array}{l}85 \\
70\end{array}$ \\
\hline $\begin{array}{l}\text { Sphalerite } \\
\text { Galena }\end{array}$ & $\begin{array}{l}0 \\
1\end{array}$ & $\begin{array}{l}0 \\
0\end{array}$ & $\begin{array}{l}0 \\
1\end{array}$ & $\begin{array}{l}0 \\
0\end{array}$ & $\begin{array}{r}\mu M \\
0 \\
1\end{array}$ & $\begin{array}{l}0 \\
0\end{array}$ & $\begin{array}{l}3 \\
2\end{array}$ & $\begin{array}{l}2 \\
3\end{array}$ & $\begin{array}{l}95 \\
92\end{array}$ \\
\hline $\begin{array}{l}\text { Sphalerite } \\
\text { Galena }\end{array}$ & $\begin{array}{l}0 \\
1\end{array}$ & $\begin{array}{l}0 \\
0\end{array}$ & $\begin{array}{l}1 \\
1\end{array}$ & $\begin{array}{l}0 \\
0\end{array}$ & $\begin{array}{r}\text { ALL } \\
1 \\
1\end{array}$ & $\begin{array}{l}0 \\
0\end{array}$ & $\begin{array}{l}3 \\
3\end{array}$ & $\begin{array}{l}3 \\
4\end{array}$ & $\begin{array}{l}92 \\
90\end{array}$ \\
\hline
\end{tabular}

LEAD CONCENTRATE

$\begin{array}{lccccccccc}\text { Mineral } & \text { Qtz } & \text { Ank } & \text { Py } & \text { Cp } & \text { Bar } & \text { Po } & \text { Sid } & \text { Sph/Gal } & \text { Free } \\ \text { Sphalerite } & 0 & 0 & 0 & 0 & 0 & 0 & 1 & 16 & 83 \\ \text { Galena } & 0 & 0 & 0 & 0 & 0 & 0 & 1 & 3 & 96\end{array}$

ZINC CONCENTRATE

$\begin{array}{lccccccccc}\text { Mineral } & \text { Otz } & \text { Ank } & \text { Py } & \text { Cp } & \text { Bar } & \text { Po } & \text { sid } & \text { Sph/Gal Free } \\ \text { Sphalerite } & 0 & 0 & 0 & 0 & 0 & 0 & 1 & 1 & 98 \\ \text { Galena } & 0 & 0 & 1 & 0 & 0 & 0 & 1 & 7 & 91\end{array}$

\section{TAILINGS}

\begin{tabular}{|c|c|c|c|c|c|c|c|c|c|}
\hline Mineral & Otz & Ank & Py & Cp & Bar & Po & sid & Sph/Gal & Free \\
\hline & \multicolumn{9}{|c|}{$+53 \mu \mathrm{M}$} \\
\hline $\begin{array}{l}\text { Sphalerite } \\
\text { Galena }\end{array}$ & $\begin{array}{r}1 \\
11\end{array}$ & $0_{2}$ & $\begin{array}{l}9 \\
9\end{array}$ & $\begin{array}{l}0 \\
0\end{array}$ & $\begin{array}{l}1 \\
2\end{array}$ & $\begin{array}{l}0 \\
2\end{array}$ & $\begin{array}{l}2 \\
4\end{array}$ & $\begin{array}{l}2 \\
2\end{array}$ & $\begin{array}{l}85 \\
68\end{array}$ \\
\hline $\begin{array}{l}\text { Sphalerite } \\
\text { Galena }\end{array}$ & $\begin{array}{l}1 \\
6\end{array}$ & $0_{2}$ & $\begin{array}{l}8 \\
16\end{array}$ & $\begin{array}{l}0 \\
0\end{array}$ & $\begin{array}{r}1 \\
3\end{array}$ & $\begin{array}{l}0 \\
1\end{array}$ & $\begin{array}{l}9 \\
4\end{array}$ & $\begin{array}{l}2 \\
2\end{array}$ & $\begin{array}{l}79 \\
66\end{array}$ \\
\hline $\begin{array}{l}\text { Sphalerite } \\
\text { Galena }\end{array}$ & $\begin{array}{l}0 \\
1\end{array}$ & $\begin{array}{l}0 \\
0\end{array}$ & $\begin{array}{r}2 \\
18\end{array}$ & $\begin{array}{l}3 \\
1\end{array}$ & $\mu$ & $\begin{array}{l}1 \\
0\end{array}$ & $\begin{array}{l}0 \\
2\end{array}$ & $\begin{array}{l}3 \\
3\end{array}$ & $\frac{85}{75}$ \\
\hline $\begin{array}{l}\text { Sphalerite } \\
\text { Galena }\end{array}$ & $\begin{array}{l}0 \\
5\end{array}$ & $\begin{array}{l}0 \\
1\end{array}$ & $\begin{array}{l}5 \\
15\end{array}$ & 2 & $\begin{array}{r}\text { ALL } \\
4 \\
1\end{array}$ & 1 & $\begin{array}{l}2 \\
3\end{array}$ & $\begin{array}{l}3 \\
2\end{array}$ & 83 \\
\hline
\end{tabular}




\section{REFERENCES}

Abbott, J.G., Gordey, S.P. and Tempelman-Kluit, D.J., 1986: Setting of stratiform, sediment-hosted lead-zinc deposits in Yukon and northeastern British Columbia. In Mineral Deposits of Northern Cordillera, CIM Spec. Vol. 37, J.A. Morin, ed., 1-18.

Analytical Services Group, 1995: Determination of carbon species in rocks and related materials. Analytical Procedures Manual, LIMS Code 1CS3C1, MSL/CANMET, NRCan, Canada.

Barbery, G., Bloise, R., Gateau, C. and Reinhart, C., 1983: Mineral liberation measurements and their interpretation. ICAM 81, Proc. 1st Int. Congr. Appl. Min., DeVilliers and Cawthorn eds., 469-473.

Bearmen, R.A., Pine, R.J. and Wills, B.A., 1989: Use of Fracture Toughness Testing in Characterizing the Comminution Potential of Rock. Proc. MMIJ/IMM Joint Symposium, Kyoto, Japan, 161-180.

Brock, J.S., 1973: Geophysical Exploration leading to the discovery of the Faro deposit. CIM Bull, Oct, 97-116.

Campbell, F.A. and Ethier, G.E., 1974: Sulfur Isotopes, Iron Content of Sphalerites, and Ore Textures in the Anvil Ore Body, Canada. Econ Geol 69, 482-493.

Carne, R.C. and Cathro, R.J., 1982: Sedimentary exhalative (sedex) zinc-lead-silver deposits, northern Canadian Cordillera. Can Min Metall Bull 75, 66-78.

Carson, D.J.T., 1977: Geological and mineralogical investigation of the metallury of the Grum orebody, Yukon Territory. unpublished report, Kerr Addison Mines, 47p.

Cecile, M.P., 1982: The lower Paleozoic Misty Creek embayment, Selwyn Basin, Yukon and Northwest Territories. Geol Surv Can, Bull 335, p78.

Chryssoulis, S.L. and Cabri, L.J., 1990: Significance of gold mineralogical balances in mineral processing. Trans IMM, Sect C, 99, 1-10.

Chryssoulis, S.L., Cabri, L.J., and Lennard, W., 1989: Calibration of the ion microprobe for quantitative trace metal analyses of ore minerals. Econ Geol 84, 1684-1689.

Chryssoulis, S.L., Gilders, R. and Salter, R., 1984: Silver carriers in the Brunswick Mining and Smelting ore. RPC, Rep No MDP/84/01, p82. 
Chryssoulis, S.L., Stowe, K.G. and Reich, F., 1992: Characterization of composition of mineral surfaces by laser-probe microanalysis. Trans IMM,Sect C, 101, 1-6.

Chryssoulis, S.L. and Wilson, J.M.D., 1990: Determination of trace silver in Faro ore. Division Report MSL 90-66 (IR), CANMET, EMR Canada, p4.

Chryssoulis, S.L., 1991: 'Invisible' gold and silver content of major sulphide minerals from the Vangorda and Faro mines. unpublished report, Curragh Resources, 10p.

Eisbacher, G.H., 1983: Devonian-Mississippian sinistral transcurrent faulting along the cratonic margin of Western North America: a hypothesis: Geol 11, 1, 7-10.

Freiman, S.W. and Swanson, P.L., 1990: Fracture of polycrystalline ceramics. In Deformation processes in minerals, ceramics and rocks, Edited by D.J. Barber and P.G Meredith, 72-83.

Fuerstenau, M.C., Miller, J.D., Pray, R.E., and Perinne, B.F., 1965: Metal ion activation in xanthate flotation of quartz. Trans. AIME, 232, 359-365.

Gabrielse, H., 1967: Tectonic evolution of the northern Canadian Cordillera. Can Jour Earth Sci 4, 271-298.

Gabrielse, H., 1985: Major dextral transcurrent displacements along the Northern Rocky Mountain Trench and related lineaments in north-central British Columbia. GSA Bull 96, $1-14$.

Gabrielse, H., Blusson, S.L. and Roddick, J.A. 1973: Geology of the Flat River, Glacier Lake and Wrigley Lake map areas. Geol Surv Can Mem 366, p153.

Gabrielse, H. and Yorath, C.J. (eds.), 1992: Geology of the Cordilleran Orogen in Canada. Geology of Canada, 4, GSC, p844.

Gaudin, A.M. 1939: Principles of Mineral Dressing. McGraw-Hill Book Co Inc., New York, 554p.

Godwin, C.I. and Sinclair, A.J. 1982: Average lead isotope growth curves for shale hosted zinc-lead deposits, Canadian Cordillera; Econ Geol 77, 675-690.

Gondi, J. 1972: Geology of the Anvil Mine. in Major lead-zinc deposits of western Canada, Field excursion A24-C24 Guidebook, Int Geol Cong 24, Montreal, 20-26.

Goodfellow, W.D., 1987: Anoxic stratified oceans as a source of sulphur in sedimenthosted stratiform $\mathrm{Zn}-\mathrm{Pb}$ deposits (Selwyn Basin, Yukon, Canada). Chem Geol, 65, 359382. 
Goodfellow, W.D. and Jonasson, I.R. 1984: Ocean stagnation and ventilation defined by $8^{34} \mathrm{~S}$ secular trends in pyrite and barite, Selwyn Basin, Yukon. Geol 12, 583-586.

Gy, P.M., 1979: Sampling of particulate materials - theory and practice. Developments in Geomathematics Series, 4, Elsevier, New York.

Hodouin, D. and Flament, F., 1985: BILMAT - Computer program for material balance data adjustment. In the SPOC manual, edited by D. Laguitton, chap 3.1, Division Report SP85-1/3.1E, 141p.

Hodouin, D., Garon M., Remillard, M. and Therien, M., 1988: Assessment of precious metals distribution in Lac Mattagami flotation plant by computer mass balance calculation. CIM Bulletin 81, 62-69.

Jennings, D.S., Jilson, G.A. and Pigage, L.C. 1980: Anvil Range stratigraphy, south central Yukon Territory. (prog with abst.), Cordilleran Section, Geol Assoc Can, Jan,1617.

Jennings, D.S. and Jilson, G.A., 1986: Geology and sulphide deposits of Anvil Range, Yukon. In Mineral Deposits of Northern Cordillera, CIM Spec. Vol. 37, J.A. Morin, ed., 319-361.

King, R.P., 1979: A model for the quantitative estimation of mineral liberation by grinding. Int J Min Proc, 6, 207-220.

King, R.P., 1990: Calculation of the liberation spectrum in products produced in continuous milling products. Proc 7th Eur. Symp. on Comminution, Ljubljana, 2, 429-444.

Klimpel, R.R. and Austin, L.G., 1983: A preliminary model of liberation from a binary system. Powder Tech, 34, 121-130.

Kuo, S.L., 1976: Geology and Geochemistry of stratabound ore deposits in south-central Yukon Territory and southwestern District of Mackenzie, Northwest Territories. Unpubl. Ph.D. thesis, Univ of Alberta, Edmonton, p587.

Kuo, S.L. and Folinsbee, R.E., 1974: Lead isotope geology of mineral deposits spatially related to the Tintina Trench, Yukon Territory. Econ Geol 69, 806-813.

Large, D.E., 1980: Geological parameters associated with sediment-hosted, submarine exhalative $\mathrm{Pb}-\mathrm{Zn}$ deposits: an empirical model for mineral exploration. Geol. Jahr. D 40, 59-129.

Large, D.E., 1983: Sediment-hosted massive sulphide lead-zinc deposits. In Sedimenthosted stratiform lead-zinc deposits. MAC Short Course, edited by D.F. Sangster, 8, 1-29. 
Laslett, G.M., Sutherland, D.N., Gottlieb, P. and Allen, N.R., 1990: Graphical assessment of a random breakage model for liberation. Powder Tech, 60, 83-97.

Lecouter, P., 1973: A lead isotope study of ore deposits from the East Kootenay District, B.C. and the Anvil District, Yukon Territory. Unpubl. Ph.D. thesis, Univ of B.C.

Leroux, M., Rao, S.R., and Finch, J.A., 1987: Selective flotation of sphalerite from Pb-Zn ore without copper activation. CIM Bulletin 80, 41-44.

Lydon, J.W., 1983: Chemical parameters controlling the origin and deposition of sediment-hosted stratiform lead-zinc deposits. MAC Short Course, edited by D.F. Sangster, 8, 175-250.

Lydon, J.W., Goodfellow, W.D. and Jonasson, I.R., 1985: A general genetic model for stratiform baritic deposits of the Selwyn Basin, Yukon Territory and District of Mackenzie. Geol Surv Can, Curr Res A, 85-1A, 651-660.

Meredith, P.G., 1990: Fracture and failure of brittle polycrystals: an overview. In Deformation processes in minerals, ceramics and rocks, Edited by D.J. Barber and P.G Meredith, 5-47.

Meloy, T.P. and Gotoh, K., 1985: Liberation in a homogeneous two-phase ore. Int J Min Proc, 14, 45-55.

Miller, J.D. and Lin, C.L., 1988: Treatment of polished section data for detailed liberation analysis. Int $\mathrm{J}$ Min Proc, 22, 41-58.

Modene, J.S., 1982: Origin and sulfur isotope geochemistry of the Grum deposit, Anvil Range, Yukon Territory, Canada. Unpubl. M.Sc. thesis, Univ. of Wisconsin-Madison, p158.

Monger, J.W.H., Souther, J.G. and Gabrielse, H., 1972: Evolution of the Canadian Cordillera: A plate tectonic model. Am Jour Sc, 272, 577-602.

Petruk, W., 1978: Correlation between grain sizes in polished section with sieving data and investigation of mineral liberation measurements from polished sections. Inst Min Metall Trans Sect C, 87, 271-278.

Petruk, W., 1986: Predicting and measuring mineral liberations in ores and mill products, and effect of mineral textures and grinding methods on mineral liberations. In Process Mineralogy VI, R.D. Hagni, ed., 393-403.

Petruk, W., 1988a: Automatic image analysis for mineral beneficiation. J Met, 40, 29-31. 
Petruk, W., 1988b: Ore characteristics that affect breakage during grinding. CANMET Report 88-5E, EMR, Canada, p24.

Petruk, W., 1989: Measurements of mineral liberation in connection with mineral liberation. In Process Mineralogy IX, W. Petruk, R.D. Hagni, S. Pignolet-Brandom, D.M. Hausen, eds., 31-36.

Petruk, W., 1989: Techniques for performing image analysis routines. In Short Course on Image Analysis Applied to Mineral and Earth Sciences, MAC, Ottawa, 19-34.

Petruk, W., 1994: Some relationships between mineral textures and extractive metallurgy. Division Report MSL 94-054 (OP\&J), CANMET, NR Canada, p11

Pigage, L.C., 1986: Geology of the Cirque barite-zinc-lead-silver deposits, northeastern British Columbia. In Mineral Deposits of Northern Cordillera, CIM Spec. Vol. 37, J.A. Morin, ed., 71-86.

Shanks, W.C., Woodruff, L.G., Jilson, G.A., Jennings, D.S., Modene, J.S. and Ryan, B.D., 1987: Sulfur and Lead Isotope Studies of Stratiform Zn-Pb-Ag Deposits, Anvil Range, Yukon: Basinal Brine Exhalation and Anoxic Bottom-Water Mixing. Econ Geol 82,600634.

Sirola, W.M., 1975: The Grum deposit. West Miner, Dec, 9-13.

Steger, H.F., 1984: Certified reference materials. CANMET Report CM84-14E, EMR, Canada, p42.

Taggart, A.F., 1945: Handbook of Mineral Dressing. John Wiley \& Sons Inc., New York, p1200.

Templelman-Kluit, D.J., 1968: Geologic setting of the Faro, Vangorda and Swim base metal deposits, Yukon Territory. Geol Surv Can, Paper 68-1A, 43-52.

Templelman-Kluit, D.J., 1970: The relationship between sulphide grain size and metamorphic grade of host rocks in some strata-bound pyritic ores. Can J Earth Sci, 7, 1339-1345.

Templelman-Kluit, D.J., 1972: Geology and origin of the Faro, Vangorda, and Swim concordant zinc-lead deposits, central Yukon Territory. Geol Surv Can, Bull 208.

Templelman-Kluit, D.J., 1979: Transported Cataclasite, Ophiolite and Granodiorite in Yukon: evidence of arc-continent collision. Geol Surv Can, Paper 79-14, p27. 
Underwood, E.E., 1970: Quantitative Stereology. Reading, Mass., Addison-Wesley,, p274.

Vokes, F.M., 1969: A review of the metamorphism of sulphide deposits. Earth Sci Rev, 5, 99-143.

Wiegel, R.L., 1972: Advances in mineral processing material balances. Can Met Quart $11,2,413-424$.

Wyslouzil, D.M. and Salter, R.S., 1990: Silver leaching fundamentals. in Lead-Zinc 90, ed. by Mackey and Prengaman, Feb 18-21, 1990, Anaheim, 87-107. 